Ricardo da Silva Sobreira

Escritas indeterminadas e sujeitos fragmentários em contos pósmodernos de João Gilberto Noll e Sam Shepard 
Ricardo da Silva Sobreira

\section{Escritas indeterminadas e sujeitos fragmentários em contos pós- modernos de João Gilberto Noll e Sam Shepard}

Tese apresentada para a obtenção do título de Doutor em Letras junto ao Programa de Pós-Graduação em Letras do Instituto de Biociências, Letras e Ciências Exatas da UNESP - Universidade Estadual Paulista "Júlio de Mesquita Filho", Campus de São José do Rio Preto.

\section{BANCA EXAMINADORA:}

Profa. Dra. Giséle Manganelli Fernandes UNESP - São José do Rio Preto

Orientadora

Prof. Dr. Manuel Fernando Medina

UofL - University of Louisville, KY.

Prof. Dr. Antonio Manoel dos Santos Silva UNESP - São José do Rio Preto.

Prof. Dr. Paulo Sérgio Nolasco dos Santos UFGD - Dourados - MS.

Profa. Dra. Norma Wimmer

UNESP - São José do Rio Preto.

São José do Rio Preto, 26 de fevereiro de 2010. 
Sobreira, Ricardo da Silva.

Escritas indeterminadas e sujeitos fragmentários em contos pósmodernos de João Gilberto Noll e Sam Shepard / Ricardo da Silva Sobreira. São José do Rio Preto : [s.n.], 2010.

177 f. : il. ; $30 \mathrm{~cm}$.

Orientador: Giséle Manganelli Fernandes

Tese (doutorado) - Universidade Estadual Paulista, Instituto de Biociências, Letras e Ciências Exatas

1. Literatura comparada - Brasileira e americana-Séc. XX. 2. Contos americanos - Séc. XX - História e crítica. 3. Contos brasileiros - Séc. XX História e crítica. 4. Indeterminação - Teoria literária. 5. Fragmentação. 6. Noll, João Gilberto, 1946-. 7. Shepard, Sam, 1923-1970. I. Fernandes, Giséle Manganelli. II. Universidade Estadual Paulista, Instituto de Biociências, Letras e Ciências Exatas. III. Título.

CDU - 82.091

Ficha catalográfica elaborada pela Biblioteca do IBILCE Campus de São José do Rio Preto - UNESP 
$M a r c o s$

Der Liebe Hand Spann mir ein Kleid von Seide

Christian Hofmann von Hofmannswaldau

"Wo sind die Stunden der süßen Zeit" 


\section{AGRADECIMENTOS}

À Profa. Dra. Giséle Manganelli Fernandes, pela orientação, apoio e, sobretudo, pelo exemplo de trabalho e de perseverança.

Ao Prof. Dr. Thomas B. Byers, pela receptividade e supervisão durante estágio na University of Louisville.

Ao Programa de Doutorando com Estágio no Exterior da CAPES, pela oportunidade de desenvolver pesquisa na University of Louisville, KY, Estados Unidos.

Ao Prof. Dr. Antonio Manoel dos Santos Silva, pela generosidade, pelas leituras atenciosas desta tese e, sobretudo, pela sugestão de referências bibliográficas fundamentais.

À Profa. Dra. Norma Wimmer, pela leitura atenta e sugestões de refinamentos teóricos.

Ao Prof. Dr. Paulo Sérgio Nolasco dos Santos e ao Prof. Dr. Manuel Fernando Medina pela aceitação do convite à leitura desta tese e pela participação na defesa pública.

Aos amigos Daniela Soares Portela e Alaor Ignácio pelo apoio, carinho e amizade ao longo dos anos. 


\section{SUMÁRIO}

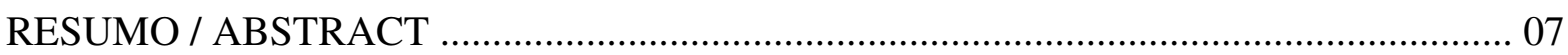

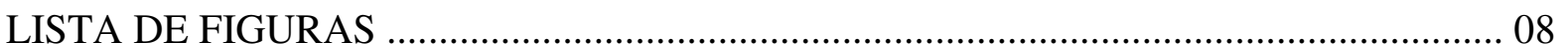

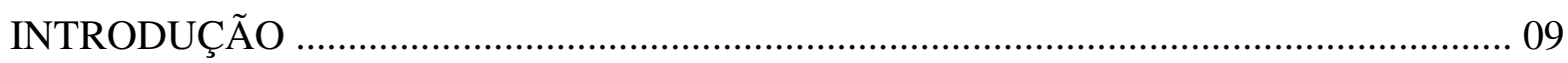

Aspectos da produção artística de João Gilberto Noll e Sam Shepard ................................ 12

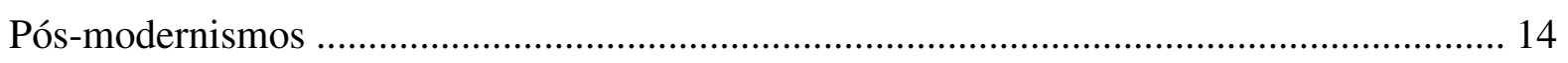

CAPÍTULO I - INSTANTES FICCIONAIS: ALGUNS ASPECTOS DOMINANTES NO

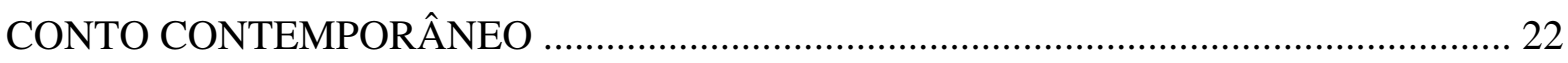

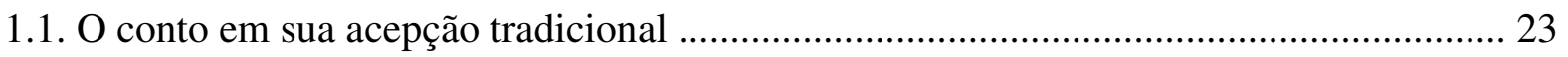

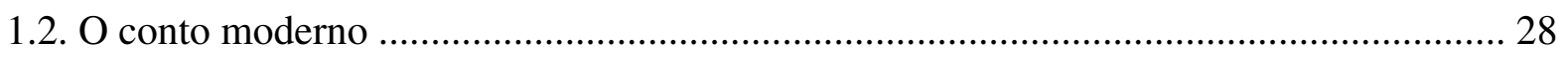

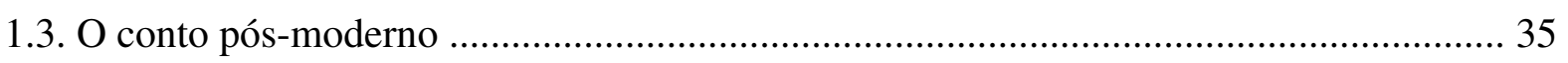

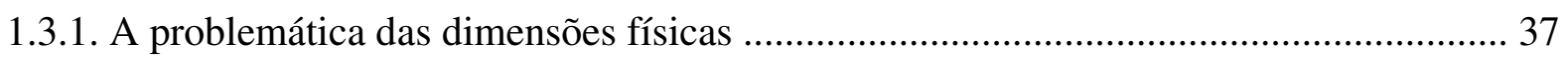

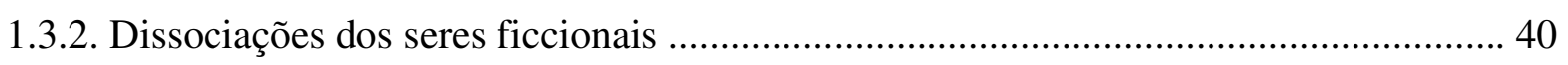

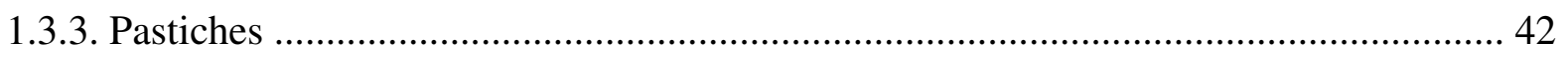

1.3.4. Quebra do continuum espaçotemporal .............................................................. 45

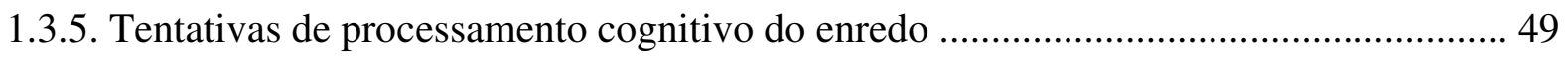

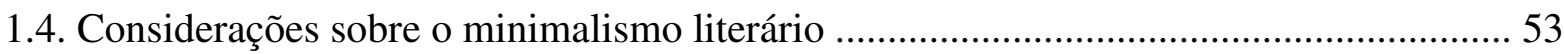

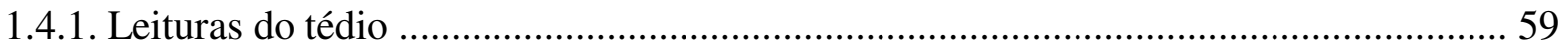

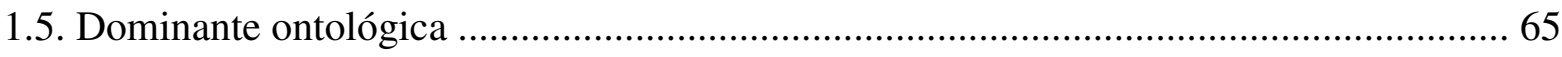

CAPÍTULO II - INDETERMINAÇÕES E PROCESSOS PARATÁTICOS EM

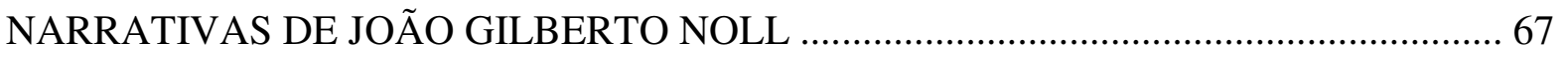

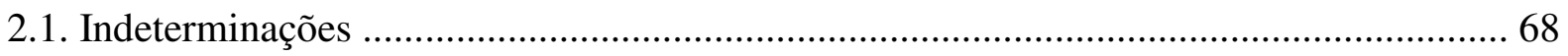

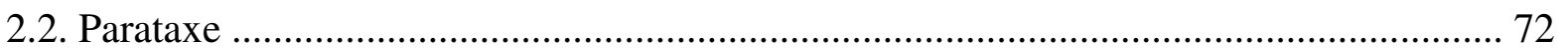

2.3. O universo instável das ficções de João Gilberto Noll ................................................ 77

2.3.1. Aspectos estruturais e traços indeterminados de Mínimos, múltiplos, comuns ............ 85 
2.4. Processamento cognitivo de narrativas de João Gilberto Noll 89

2.5. Traços indeterminados e processos paratáticos em textos de Mínimos, múltiplos, comuns 92

CAPÍTULO III - IDENTIDADES E PERSPECTIVAS FRAGMENTADAS EM SAM

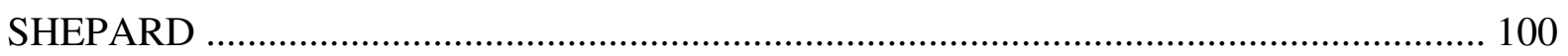

3.1. Considerações sobre a coletânea Great Dream of Heaven ......................................... 107

3.2. O universo imaginário de Sam Shepard .................................................................... 112

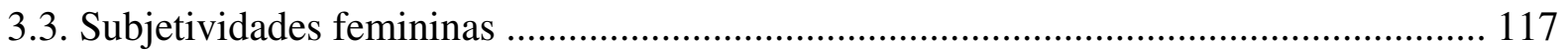

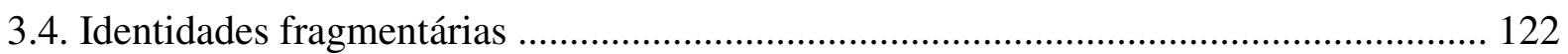

3.5. Multiplicação / Dissolução de identidades em Shepard ................................................. 127

3.6. A desestabilização do narrador como centro organizador da percepção ........................ 140

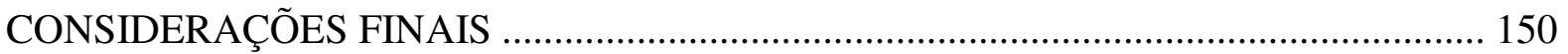

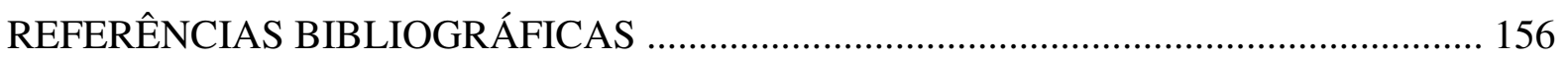

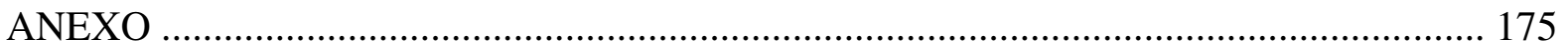




\title{
RESUMO
}

A presente tese consiste em um estudo de técnicas narrativas como a indeterminação (cf. ECO, 1969; HASSAN, 1987) e a fragmentação (cf. CURRIE, 1987; RUBENSTEIN, 1994; CALABRESE, 1999, p.84-90) em contos publicados nos livros Great Dream of Heaven (2002), do autor norte-americano Sam Shepard, e Mínimos, múltiplos, comuns (2003), do escritor brasileiro João Gilberto Noll. Com base em teorias associadas ao pós-modernismo (HASSAN, 1987; McHALE, 1987; JAMESON, 1991; VATTIMO, 2007), analisamos os procedimentos artístico-formais mobilizados pelos escritores como, por exemplo, usos criativos de processos paratáticos, indeterminações narrativas, desordens espaçotemporais e dissociações de imagens e ideias. As análises empreendidas orientam-se no sentido de demonstrar como as narrativas atípicas de Noll e Shepard instalam e subvertem expectativas e convenções do gênero conto. Além disso, esse estudo objetiva não apenas refletir sobre uma possível emergência do conto pós-moderno, mas também examinar como as estratégias narrativas mobilizadas pelos autores sugerem a fragmentação e a multiplicação de identidades (cf. HALL, 1987, 1992; BAUMAN, 2004) do sujeito ficcional no âmbito da contemporaneidade.

PALAVRAS-CHAVE: Sam Shepard; João Gilberto Noll; Indeterminação; Fragmentação; Conto; Parataxe; Sujeito.

\begin{abstract}
This dissertation presents a study of narrative techniques such as indeterminacy (cf. ECO, 1969; HASSAN, 1987) and fragmentation (cf. CURRIE, 1987; RUBENSTEIN, 1994; CALABRESE, 1999, p.84-90) in short stories published in the books Great Dream of Heaven (2002), by the American author Sam Shepard, and Mínimos, múltiplos, comuns (2003), by the Brazilian writer João Gilberto Noll. Based on theories on postmodernism (HASSAN, 1987; McHALE, 1987; JAMESON, 1991; VATTIMO, 2007), this work analyzes artistic and formal procedures employed by the authors such as, for instance, their creative use of paratatic processes, narrative indeterminacies, space-time disorders, and dissociations of images and ideas. These analyses aim at showing how the atypical narratives of Noll and Shepard both use and subvert expectancies and conventions of the short story as a genre. Besides, the objective of the present study is not only to reflect upon a possible emergence of postmodern short story, but also to examine how the narrative strategies deployed by the authors suggest fragmentation and multiplication of identities (cf. HALL, 1987, 1992; BAUMAN, 2004) of the fictional subject in the contemporary world.
\end{abstract}

KEYWORDS: Sam Shepard; João Gilberto Noll; Indeterminacy; Fragmentation; Short Story; Parataxis; Subject. 


\section{LISTA DE FIGURAS}

Fig. 1 - Jasper Johns. Untitled (de Foirades/Fizzles), Museu Ludwig, Cologne.

Fig.2 - A atriz Sarah Polley em cena do filme Don't Come Knocking (EUA, 2005).

Figs. 3 a 4 - Ilustrações do livro Mínimos, múltiplos, comuns (NOLL, 2003a, p.254-255, 266-267, 318-319). 


\section{INTRODUÇÃO}

O presente trabalho desenvolve um percurso de análise de alguns contos contemporâneos, em especial textos do autor brasileiro João Gilberto Noll (1946-) e do escritor e dramaturgo norte-americano Sam Shepard (1943-), que incorporam à narrativa uma trama de referenciais "incompletos", enredos descontínuos, situações ambíguas ou indeterminadas. Por essa razão, esses textos emergem como artefatos literários em que a apreensão e a concatenação dos dados narrativos são dificultadas ou mesmo frustradas em decorrência do emprego deliberado de estratégias narrativas como o recorrente uso de processos paratáticos, a fragmentação de diversos aspectos do universo imaginário, a descontinuidade do relato, além da tessitura elíptica e indeterminada do enredo e, sobretudo, da desestabilização do narrador como centro organizador da percepção.

Embora a escrita de contos não seja a atividade predominante de nenhum dos dois autores - a maior parte da produção de Noll tem sido publicada sob a forma de romances e Shepard possui um número exponencialmente maior de peças teatrais do que qualquer outro tipo de escrita - as narrativas breves de ambos os autores reúnem os elementos essenciais para o desenvolvimento da presente pesquisa.

A partir da escolha dos autores, procedemos, durante a fase inicial do estudo, à determinação das narrativas a serem examinadas e decidimos pela coletânea de contos mais recente de cada escritor na época. ${ }^{1}$ Desse modo, optamos pela investigação dos livros Great Dream of Heaven (2002) e Mínimos, múltiplos, comuns (2003). Embora materialmente distintos - o volume de Noll supera o de Shepard em brevidade e em número de páginas e de narrativas - cada uma dessas duas coletâneas contou, antes do lançamento em formato livro, com a publicação de histórias isoladas em veículos periódicos voltados para a comunicação em massa: textos de Great Dream of Heaven saíram primeiro nas revistas LA Weekly e The New Yorker, e textos de Mínimos, múltiplos, comuns foram publicados pelo jornal Folha de S. Paulo, duas vezes por semana entre agosto de 1998 e dezembro de 2001 (cf. CARELLI, 2003, p.20). Nosso trabalho busca levar em consideração esses lançamentos

\footnotetext{
${ }^{1}$ Os autores pesquisados publicaram, posteriormente, outras coletâneas de contos: A máquina de ser (NOLL, 2006) e Day Out of Days (SHEPARD, 2010).
} 
híbridos em termos de mídias, sobretudo ao compararmos o processamento cognitivo de estruturas narrativas à atividade de interação com dados presentes em textos de cunho informativo.

Embora de maneiras e intensidades distintas, podemos notar que as narrativas de ambos os livros projetam universos imaginários exacerbadamente indeterminados, caracterizados por lacunas e supressões. Essas características limitam o leitor na sua tentativa de estabelecer a significação de algumas proposições articuladas pelas histórias. Entre várias das razões apontadas para a ocorrência desses aspectos nas narrativas, destacamos o fato de o narrador desses pequenos relatos, quase sempre acometido pela impossibilidade de apreender a complexidade dos fatos aleatórios de seu cotidiano, deixar de ser o elemento axial de organização das unidades significativas do texto e, dessa forma, construir uma narrativa "porosa”, marcada por um nível acentuado de fragmentações e indeterminações.

Por meio dessa percepção da recorrência de aspectos fragmentários e indeterminados em alguns textos dos escritores focalizados nesta tese, verificamos que tanto Noll quanto Shepard, além de muitos outros autores em atividade no Brasil e no exterior, tendem a levar esses dois aspectos tradicionalmente vinculados à arte do conto, sobretudo quando consideramos a produção de Ernest Hemingway e Raymond Carver, a patamares ainda mais drásticos. Em outras palavras, alguns dos contos de Shepard e, em especial, os textos de Noll tendem a provocar uma acentuada desordem ou supressão tanto de referenciais espaçotemporais dos acontecimentos como de aspectos físicos e psicológicos das personagens.

Dessa maneira, nosso trabalho pretende orientar-se no sentido de analisar como a rarefação de dados narrativos vinculados a tempo, espaço e, até certa medida, à própria personagem - que, no entanto, não tem necessariamente uma ligação com as noções de narrativa sem história, ou conto de atmosfera - colabora, por meio de desarranjos ou da obliteração desses referenciais, para projetar universos ficcionais instáveis, povoados por personagens anônimas e sem destino. A presente pesquisa também vincula a figura exacerbadamente inafiançável, problemática e descentrada do narrador, quase sempre 
corporificada em um eu-protagonista masculino, aos próprios deslocamentos e instabilidades identitárias do sujeito pós-moderno. ${ }^{2}$

Para tanto, leituras especializadas da fortuna crítica dos autores em pauta, bem como extensas reflexões em torno de estudos sobre o fenômeno literário foram mobilizadas com o intuito não de explicar, em termos autoritários, ou de exaurir os numerosos impasses e paradoxos instaurados por esses contos fragmentários e lacunares, mas no sentido de promover a circulação de leituras, que, no caso das narrativas pesquisadas, podem no máximo oferecer produções de sentido provisórias e não totalizantes. ${ }^{3}$ Nesse sentido, optamos por abordar os artefatos literários pesquisados tomando como referência teorias relacionadas à dominante cultural do pós-modernismo, sobretudo os pressupostos teóricos envolvendo aspectos que favorecem produções textuais fragmentárias, descontínuas e instáveis, desenvolvidos por autores como Fredric Jameson, Brian McHale, Ihab Hassan, entre outros.

Entretanto, antes de tecermos maiores considerações sobre a relevância de teorias vinculadas ao pós-modernismo para o desenvolvimento deste trabalho - noção que esperamos refinar mais adiante - faz-se necessário um breve levantamento da trajetória de João Gilberto Noll e de Sam Shepard, para que possamos contextualizar as duas coletâneas de contos dentro do panorama mais amplo da produção artística de ambos os escritores.

\footnotetext{
${ }^{2}$ A noção de sujeito sob a perspectiva pós-moderna emerge a partir de amplas discussões teóricas recentes, às quais teremos oportunidade de retornar, sobretudo na seção 3.4 do presente trabalho. Cabe esclarecer, neste momento, que a referida concepção de sujeito é formada a partir de teorias pós-modernas, cuja orientação dá-se em favor da suspensão de hipóteses, defendidas durante o período moderno, referentes à relativa coerência social e lógica causal atribuída ao sujeito humano. Conforme observam Best \& Kellner (1991), "a teoria pósmoderna abandona o sujeito racional e unificado postulado por grande parte das teorias modernas em favor de uma forma de subjetividade fragmentada e linguisticamente descentrada" (p.4-5). A atual conjuntura do capitalismo tardio, caracterizada pela ênfase no consumismo e na cultura midiática (JAMESON, 2006, p.22-23), tem suscitado a coexistência de identidades múltiplas, híbridas e, muitas vezes, contraditórias no âmbito da subjetividade do indivíduo (HALL, 1992, p.277). Este, por sua vez, não pode mais ser considerado único, acabado ou estável, mas como um campo de ações performáticas, marcado pela "multiplicidade, pluralidade, fragmentação e indeterminação" (BEST \& KELLNER, 1991, p.4).

${ }^{3}$ A noção de totalização refere-se a quaisquer mecanismos, práticas ou estratégias que visem ao exercício de controle ou a criação de unicidade em relação a elementos (sejam discursivos, factuais, conceituais etc.) díspares com a finalidade de produzir fechamentos "harmônicos" ou representações positivistas ou humanistas plenas e unificadas (HUTCHEON, 1988, p.ix). Uma das características fundamentais do pós-modernismo, conforme salienta Rincón (1995), diz respeito à incapacidade ou inviabilidade de totalizações uma vez que "os grandes modelos para explicar o mundo, os grandes sistemas de pensamento, as racionalizações que eliminam todas as incertezas já não funcionam mais ou, no máximo, funcionam em certos aspectos, para determinados setores da humanidade, sob determinadas circunstâncias. Esses sistemas, esses modelos, essas racionalizações não podem ser aplicadas universalmente" (p.123).
} 


\section{Aspectos da produção artística de João Gilberto Noll e Sam Shepard}

Nascido em Porto Alegre no ano de 1946, João Gilberto Noll despontou para a literatura no início da década de oitenta com o premiado volume de contos $O$ cego e a dançarina (1980). Desde então, o escritor tem publicado vários romances como A fúria do corpo (1981), Bandoleiros (1985), Rastros de verão (1986), Harmada (1993), A céu aberto (1996), entre outros, que lhe têm angariado o interesse do público, além de cinco prêmios Jabuti, convites para lecionar literatura brasileira no exterior, bolsas de apoio ao escritor e adaptações de seus textos para o teatro e o cinema.

Entre essas adaptações, destaca-se o filme Nunca fomos tão felizes (Brasil, 1983), do diretor Murilo Salles, baseado no conto "Alguma coisa urgentemente", presente no volume de estreia de João Gilberto Noll. Vale mencionar ainda a recente produção cinematográfica Hotel Atlântico (Brasil, 2009), realizada pela diretora Suzana Amaral, baseada em romance homônimo de Noll.

Ao contrário de Sam Shepard, cuja produção em prosa tem ocorrido de maneira intermitente e quase como um "desvio" de sua atividade principal (o teatro), em Noll encontramos um artista totalmente focado na construção de narrativas. Tendo iniciado, ao contrário de Shepard, sua carreira artística em idade madura, Noll tem mantido uma contínua produtividade, cujo resultado é a publicação de vários romances e contos.

A coletânea Mínimos, múltiplos, comuns insere-se dentro deste contexto como uma forma distinta no trabalho do romancista. Trata-se de uma coletânea de 338 textos, ou "milimétricos surtos ficcionais", como define o autor. O caráter indeterminado dos sujeitos e a narrativa descontínua das experiências humanas flagradas por esses "instantes ficcionais" (BRASIL, 2003, p.1) são sugeridos, na economia do texto, pelo emprego de omissões drásticas de dados narrativos bem como processos paratáticos, que fragmentam as percepções em mínimas parcelas plásticas e indeterminadas.

Quanto a Sam Shepard, cabe ressaltar que a sensibilidade criativa do autor americano encontra expressão em diversas formas de arte como drama, cinema, música e literatura. A própria trajetória de prêmios e reconhecimento público de Shepard mostra tanto o interesse popular quanto a atenção crítica despertados por seus trabalhos. No cinema, por exemplo, além de participações em filmes de apelo comercial como Falcão Negro em perigo 
(Black Hawk Down, EUA, 2001) e O assassinato de Jesse James pelo covarde Robert Ford (The Assassination of Jesse James by the Coward Robert Ford, EUA, 2007), entre diversos outros títulos, Shepard já foi indicado ao Oscar como ator por seu papel em Os eleitos (The Right Stuff, EUA, 1983), em 1984. Naquele mesmo ano, o filme Paris, Texas (França, Alemanha, EUA, 1984), roteirizado por Shepard e L. M. Kit Carson, e dirigido por Wim Wenders, recebeu a Palma de Ouro no Festival de Cannes. São dignos de menção ainda outros dois trabalhos de Shepard para o cinema: a colaboração com o diretor Robert Altman no filme Louco de amor (Fool For Love, EUA, 1985), estrelado e roteirizado por Shepard, a partir de peça homônima de sua autoria; e Estrela Solitária (Don't Come Knocking, EUA, Alemanha, 2005), uma nova parceria entre Shepard (roteiro) e o diretor alemão Wim Wenders, protagonizado pelo próprio Shepard e sua esposa, a atriz Jessica Lange.

Contudo, é no teatro que o autor tem realizado a maior parte de sua produção, tendo já escrito, montado e publicado mais de quarenta peças, recebido vários prêmios Obie e o prêmio Pulitzer por Buried Child (1978) e consolidado-se como uma das principais vozes do drama americano da segunda metade do século XX (cf. SIEGEL, 1982, p.236; COHN, 1988, p.1118-1119; SHEWEY, 1997, p.4; ZELLAR, 2002, p.1; JAMES, 2002, p.30).

Paralelamente às carreiras de dramaturgo, roteirista, ator e diretor, Shepard, a partir dos anos setenta, tem se dedicado à publicação, ao menos uma vez a cada década, de uma coletânea de textos diversos, predominantemente em prosa. Esses trabalhos incluem as coletâneas Hawk Moon (1973), Motel Chronicles (1982), Cruising Paradise (1996) e Great Dream of Heaven (2002). Os dois primeiros livros incluem relatos, crônicas, poemas e monólogos, e os dois últimos são volumes de contos. Contudo, suas capacidades de representar momentos instantâneos da realidade e de plasmar de maneira artística os dilemas familiares e as crises de identidade vivenciadas por suas personagens, dentro das possibilidades artísticas do conto, revelam-se com maior intensidade em seu volume mais recente de narrativas breves, Great Dream of Heaven. Esse livro constitui uma coletânea de textos mais maduros do ponto de vista artístico, ao deixar de lado o tom excessivamente autobiográfico ou improvisado que comprometiam as coletâneas anteriores e, de certa forma, impediam um maior interesse crítico por essa outra faceta do autor.

Além de características como a incorporação de níveis significativos de aspectos indeterminados e fragmentários à trama narrativa do conto, outros traços dominantes são compartilhados por ambos os autores: tanto João Gilberto Noll como Sam Shepard 
desenvolveram narrativas nas quais sujeitos deslocam-se não apenas para fora de redes sociais de familiaridade, mas principalmente em direção a destinos incertos. Esses viajantes erráticos, figuras recorrentes em romances de Noll e peças de Shepard, perambulam também pelos contos de ambos os autores, algumas vezes migrando de uma história para outra, em jornadas indefinidas por extensões territoriais intermináveis. Por essa razão, percebemos em textos dos dois escritores, apesar das diversas variáveis de cunho estético e cultural, tentativas de concretizar, no texto narrativo, respostas artísticas sob a forma de relatos de experiências vivenciadas pelo sujeito, sobretudo do sexo masculino, em pleno contexto da pósmodernidade. Dessa maneira, muitas das indeterminações e fragmentações (psíquicas e físicas) presentes nesses sujeitos e nas narrativas que tentam plasmar suas vivências e perambulações sugerem disjunções e crises de identidade da própria noção de sujeito sob a perspectiva pós-moderna. São alguns desses traços comuns, dentre os vários pontos de contato que esperamos estabelecer ao longo deste trabalho, que motivaram a realização deste estudo dos dois autores.

Entretanto, antes de prosseguir, faz-se necessário explicitar de maneira sucinta como entendemos as várias implicações de termos relacionados ao pós-modernismo e qual a relevância crítica dessas noções teóricas para a presente pesquisa.

\section{Pós-modernismos}

Em primeiro lugar, devemos diferenciar alguns termos-chave para a fundamentação teórica do presente trabalho: i) modernidade; ii) modernismo; iii) pós-modernidade; iv) pósmodernismo; e v) pós-moderno. Trata-se de uma tarefa complexa, pois, além dessa terminologia encerrar instabilidades semânticas, os conceitos que estes termos pretendem designar muitas vezes apresentam formulações divergentes a depender das variações locais.

A noção de modernidade com a qual operamos neste trabalho refere-se ao período que sucede o capitalismo mercantil, em especial, a fase cujo início ocorre a partir de meados do século XIX com a emergência do capitalismo financeiro. A modernidade, como sabemos, destaca-se pela introdução de profundas transformações sociais, culturais e econômicas, além de marcar o reconhecimento do ser humano como um ser autônomo, autossuficiente, cuja capacidade racional, segundo o legado iluminista, viabilizaria sua atuação consciente sobre a 
natureza e a sociedade (cf. SANTOS, 2000, p.77). Apesar das inúmeras variantes locais, pode-se dizer que se trata de uma era dinâmica, caracterizada por grandes inovações tecnológicas e pelo progresso científico, no qual "se julgava que a razão fosse capaz de descobrir modelos teóricos e práticos adequados, sob os quais sistemas de pensamento e ação poderiam ser construídos e a sociedade poderia ser reestruturada" (BEST \& KELLNER, 1991, p.2). ${ }^{4}$ Nesse sentido, Gianni Vattimo avalia que a modernidade "pode caracterizar-se, de fato, por ser dominada pela ideia de história do pensamento como uma 'iluminação' progressiva" (2007, p.vi).

O termo modernismo é empregado no presente trabalho para identificar, de maneira geral, o amplo contexto de práticas artísticas inovadoras presentes na literatura e em outras artes durante fins do século XIX e nas décadas iniciais do século XX, especialmente após a Primeira Guerra Mundial. Segundo alguns teóricos, os modernismos literários, sobretudo em nações europeias avançadas e nos Estados Unidos, surgiram a partir de interações com as estéticas vanguardistas e parecem compartilhar de uma busca pela ruptura com aspectos alienantes promovidos pela industrialização e pelos modos de vida conservadores vigentes em grandes centros urbanos (BEST \& KELLNER, 1991, p.2). Contudo, para evitar equívocos terminológicos e levando em consideração o fato de que analisamos textos de um autor americano e um brasileiro, restringimos o uso do termo aos modernismos conforme ocorreram em seus respectivos países. Embora o detalhamento de obras e autores desses períodos não faça parte do escopo do presente trabalho, vale mencionar algumas características básicas de ambos os movimentos. Nos Estados Unidos, o modernismo alcançou seu ápice entre as décadas de 20 e 40 do século passado e pode ser caracterizado pela criação de obras formalmente extravagantes e "visionárias", que primavam pelos experimentos formais e estilísticos. Outras características incluem a tentativa de ruptura parcial com as tradições culturais e artísticas do passado em favor da constante inovação, bem como tensões entre a consciência do sujeito individual e os impulsos aquisitivos do mundo dos negócios (ANDERSON, 1988, p.702-703). Alguns teóricos recentes criticam os modernistas, sobretudo os americanos, pela pretensão de "expressar o todo das experiências

\footnotetext{
${ }^{4}$ Reason was deemed competent to discover adequate theoretical and practical norms upon which systems of thought and action could be built and society could be restructured. Salvo quando indicado na bibliografia, todas as traduções livres utilizadas no presente trabalho são de responsabilidade do autor da pesquisa. Cabe observar ainda que, em razão do novo acordo ortográfico, optamos por adaptar todas as citações, inclusive as anteriores ao acordo, às normas agora vigentes, evitando, dessa forma, o registro de grafias diferentes para a mesma palavra ao longo da tese. Considerada a natureza meramente gráfica dessa uniformização, não há, por conseguinte, prejuízos em termos de sentido para o leitor.
} 
da vida moderna" ${ }^{, 5}$ recorrendo a esquemas totalizantes, que, apesar de fragmentários e experimentais na superfície, tendem a revelar uma lógica conceitual relativamente homogênea e conservadora. ${ }^{6}$ Andreas Huyssen (1993), por exemplo, critica não apenas um suposto hermetismo das grandes obras literárias modernas, mas também a persistência em enfatizar a autonomia da arte moderna em relação à vida cotidiana e em defender a "pureza da arte elevada contra as contaminações da urbanização, da massificação, da modernização tecnológica - isto é, da moderna cultura de massa" (p.223). ${ }^{7}$ Quanto ao contexto brasileiro, o termo modernismo, neste trabalho, aplica-se não somente às correntes artísticas representadas pela Semana de Arte Moderna, mas pelos desdobramentos posteriores à década de 1930, a partir da qual os movimentos de pesquisa estética e atualização artística consolidam-se nos fazeres literários nacionais. De maneira geral, o modernismo no Brasil representou momentos de experiências de linguagem, de inconformismo cultural sob a forma de crítica ao pensamento tradicional das velhas gerações e da exploração inovadora de aspectos formais e temáticos das obras literárias (BOSI, 1994, p.331-416).

O termo pós-modernidade é usado para marcar a transição entre o paradigma da modernidade e um novo paradigma (SANTOS, 2000, p.34; VATTIMO, 2007, p.ix), conhecido também como era pós-moderna. Dessa forma, a pós-modernidade refere-se a um estágio social, histórico e econômico, que supostamente suceda a modernidade. Essa transição seria marcada pela emergência do capitalismo tardio — ou do "capitalismo desorganizado", conforme defende Boaventura de Souza Santos (2000, p.87) — e pela decorrente substituição da produção de mercadorias através do trabalho industrial por estilos de vida individualistas, sobretudo nas chamadas sociedades mais avançadas, baseados no consumismo exacerbado de produtos e símbolos, em grande parte, oferecidos pela cultura e mídia de massa (SMITH, 2001, p.215; TRODD, 2001; AUSLANDER, 2004). Nessa passagem para a economia do capital multinacional — marcada pelas tecnologias midiáticas high tech e pelo extravasamento de fronteiras geopolíticas do capital e da cadeia produtiva -

\footnotetext{
${ }^{5}$ to express the whole experience of modern life (Id., ibid., p.698). Nesse mesmo sentido, Eco (1969) analisa que o autor moderno James Joyce "quer, ambiciosamente, que ele [o cosmo projetado nas páginas de Ulysses] implique a totalidade do espaço e do tempo" (p.48, grifos nossos).

${ }^{6}$ Aos desenvolvimentos mais depurados desse conservadorismo e elitismo, presentes, sobretudo, no período final do modernismo americano, alguns críticos reservaram o rótulo de high modernism (alto modernismo). Durão (2006), por exemplo, comenta que "já é um lugar comum amplamente aceito nos Estados Unidos que seu modernismo conteve algo de repressor e paralisante. Implícita na expressão corrente, high modernism, está a crença de que o projeto modernista [...] tinha como ambição inconfessa estabelecer um império da forma e da canonicidade, da rigidez estrutural e do reformismo político-cultural” (p.41).

${ }^{7}$ the purity of high art from the encroachments of urbanization, massification, technological modernization in short, of modern mass culture.
} 
alguns críticos defendem que o sujeito humano sofre um processo de fragmentação do antigo ideal de uma identidade pessoal unificada e autossuficiente (JAMESON, 1986, p.67; HALL, 1992; SANTOS, 2000, p.107). Outra mudança paradigmática ocasionada pela emergência da era pós-moderna está relacionada à crise de legitimação das formas universalistas e totalizantes de conhecimento, responsáveis pela regulação e pela emancipação do paradigma sociocultural da modernidade. Essa crise suscita uma situação de incredulidade geral em relação às metanarrativas e tende a favorecer o desenvolvimento de formas epistemológicas locais e menos homogêneas (LYOTARD, 1988). Essa condição pós-moderna torna-se, portanto, crucial para o estabelecimento de formas de pensamento e práticas estéticas calcadas em elementos provisórios, contextuais e não totalizantes.

Quanto à noção de pós-modernismo, é possível observar que este termo é passível de numerosas formulações, dentre as quais, destaca-se a denominação genérica de estilos e movimentos artísticos e estéticos surgidos, sobretudo, em sociedades avançadas no último quartel do século XX. Estes se definem como uma visão de mundo ou um "conjunto de ideias filosóficas que não apenas sustentam uma estética, mas também examinam uma condição cultural de 'capitalismo tardio' da 'pós-modernidade"” (BUTLER, 2002, p.3). ${ }^{8}$ Segundo Smith (2001), algumas das posições teóricas e práticas artísticas emergentes do pósmodernismo, muitas delas surgidas a partir de teorias pós-estruturalistas, rejeitam os rigores filosóficos e estéticos modernos ao promoverem a incorporação acentuada de traços formais e técnicas provenientes de estilos do passado por meio da intensificação de paródias, pastiches, hibridismos, bem como do aproveitamento eclético de elementos tanto da cultura pop ou de massa quanto da cultura erudita (p.215). As práticas artísticas pós-modernas, de modo geral, buscam eclipsar não apenas as hierarquias e fronteiras rígidas entre gêneros e discursos díspares, mas também suscitar interações, muitas vezes paradoxais ou "estranhas", entre elementos oriundos de produtos culturais tradicionalmente incompatíveis ou mutuamente excludentes. Nesse sentido, Rincón (1995) acrescenta que:

O privilégio da pluralidade e da multiplicidade estilística, da apropriação irônica do passado e da história em geral, da construção dinâmica de identidades, e da emergência dos discursos do Outro, de múltiplos sujeitos históricos, que se

\footnotetext{
8 set of philosophical ideas that not only support an aesthetic but also analyse a 'late capitalist' cultural condition of 'postmodernity'.
} 
redefinem (mulheres, minorias) são, além disso, temas pósmodernos que se abrem à análise política (p.36). ${ }^{9}$

Como a citação acima busca mostrar, o pós-modernismo, por meio de variadas práticas e estilos, rejeita a posição relativamente elitista associada ao modernismo, sobretudo o norte-americano, em favor de artefatos literários saturados pela interpenetração de elementos provenientes de sistemas de significação tão diversos quanto a publicidade, as formas canônicas de arte, a moda, o cinema comercial, os discursos histórico e científico, a televisão, a cultura de massa etc. Embora não seja possível negar a intensa circulação de textos e teorias vinculadas ao pós-modernismo, alguns críticos como Terry Eagleton questionam a própria significância do termo uma vez que, ao se propor a abranger fenômenos culturais díspares e variados, o conceito ameaça resvalar na falta de sentido (1996, p.2002001).

Cabe salientar, finalmente, que o termo pós-moderno, por conseguinte, é um adjetivo mais amplo que engloba traços relacionados tanto à pós-modernidade (como em "sociedade pós-moderna") quanto ao pós-modernismo (como em “estilo pós-moderno"). Porém, quando subtantivado, o termo pode ser entendido como sinônimo de pós-modernismo.

A aplicação de um rótulo como pós-moderno, sobretudo em um país como o Brasil, é cercada de questões problemáticas tendo em vista as diversas conotações e implicações do termo. A primeira delas diz respeito à própria possibilidade da emergência da pósmodernidade - condição intrinsecamente associada ao consumismo, à obsolescência programada da mercadoria, ao fluxo frenético de informações e à tecnologia avançada - em locais designados (de modo pejorativo) como Terceiro Mundo, isto é, em países nos quais, ao longo de vastas extensões territoriais, haveria ainda a carência de pré-requisitos básicos até mesmo para se atingir a modernidade como a alfabetização, a industrialização e a mobilidade das populações (cf. SANTIAGO, 1993, p.195-196).

Entretanto, mesmo em face de um país de dimensões continentais como o Brasil, marcado por múltiplos e complexos contrastes e diferentes conjunturas em nível regional e até estadual, argumentamos que há sentido em se falar de pós-modernidade no contexto

\footnotetext{
${ }^{9}$ El privilegio de la pluralidad y de la multiplicidad estilistica, de la apropiación irónica del pasado y de la historia en general, de la construcción dinámica de identidades, y el descubrimiento de los discursos del Otro, de múltiplos sujetos históricos que se redefinen (mujeres, minorías), son, además, temas postmodernos que se abren al análisis político.
} 
brasileiro. Conforme argumenta Silviano Santiago, em "Reading and Discursive Intensities: On the Situation of Postmodern Reception in Brazil" (1993), ainda que o Brasil seja um país lutando para se modernizar e de alguma forma e, em muitos sentidos, superar os desnivelamentos sociais, econômicos e, sobretudo, educacionais, há uma emergência de produtos culturais pós-modernos em circulação no país.

Apesar dos agudos desnivelamentos, que ficam patentes ao compararmos os altos níveis de consumo médio e circulação de informações nas nações mais desenvolvidas com as inúmeras carências enfrentadas por grande parte das populações de países do Terceiro Mundo, Anderson nota que as desigualdades em termos de desenvolvimento são inerentes à maioria dos sistemas, seja o capitalismo ou a pós-modernidade (1998, p.121). Por outro lado, a falta de um alto nível de consumismo de mercadorias e de tecnologias de informação não deve ser tomada como uma cláusula impeditiva para a penetração da pós-modernidade em nações menos desenvolvidas, pois o consumo de novas tecnologias e a difusão da chamada sociedade do espetáculo são fenômenos recentes até mesmo em um país rico como os Estados Unidos (Id., ibid., p.122). Além disso, o alcance de meios de comunicação de massa, sobretudo a televisão, é enorme nos países em desenvolvimento e, segundo Anderson, são esses sistemas de comunicação global que garantem um grau incomparavelmente maior de penetração cultural do Primeiro Mundo no restante do planeta. E ainda que a influência da mídia pós-moderna esteja longe de constituir uma predominância hegemônica em muitas culturas, há a possibilidade de que o pós-moderno esteja apenas em nível emergente e que, com a introdução de cada nova tecnologia, o raio de abrangência do pós-moderno vá aumentando (Id., ibid., p.121-123).

Por esses motivos, não devemos subestimar o papel que aspectos dessa dominante cultural desempenham no Brasil e em outros países em desenvolvimento, pois, conforme argumenta Perry Anderson, o fenômeno artístico e filosófico do pós-modernismo não é um fenômeno exclusivo das nações ricas (1998, p.74). Dessa maneira, se considerarmos a noção de Jameson (1991) de que o pós-modernismo é a lógica cultural do capitalismo tardio, veremos que a dominante cultural tende a emergir de forma análoga a um sistema globalizado como o capitalismo tardio, isto é, de modo mais ou menos indiferente (como ocorre com o capital em seu estágio mais avançado) às fronteiras geopolíticas.

Quer seja fruto de um desenvolvimento desigual, como é comum à maioria dos sistemas, ou não, o fato é que a cultura e a arte brasileiras, em muitos aspectos, têm sido 
expostas ao fenômeno do pós-modernismo de maneiras e intensidades diferentes e elaborado respostas diversas. Por essa razão, críticos nacionais e estrangeiros têm cada vez mais reconhecido no trabalho de nossos artistas, sobretudo no de escritores como Silviano Santiago, Haroldo Maranhão, Sérgio Sant'Anna (cf. JOHNSON, 2004, p.133-134), João Gilberto Noll (cf. VILLAÇA, 1996; JOHNSON, 2004, p.133-134), Ignácio de Loyola Brandão (RINCÓN, 1995, p.99-100), entre outros, uma nova geração de ficcionistas que incorporam em seus textos traços associados ao pós-modernismo. ${ }^{10}$

A esse respeito, Italo Moriconi, em "The Postmodern Debate: Brazilian Force Fields" (2005), reconhece, nos movimentos neoconcretista e tropicalista, elementos de transição do modernismo rumo a uma estética pós-moderna e mostra como essa dominante cultural, que entrou no campo de força intelectual brasileiro no início da década de 1980 (2005, p.355), tem se consolidado entre nós:

\begin{abstract}
o hipertexto na ficção, a presença universal da mídia como um denominador comum da produção de subjetividades, a linguagem pop como um conjunto universal de referências para o pensamento estético futuro, a infinita proliferação de signos, a importância das retóricas do paradoxo e das sintaxes paratáticas, a noção das identidades múltiplas e fragmentárias bem como a fragmentação do significado: esses são só alguns elementos que habitam o imaginário pósmoderno no Brasil, assim como em outros locais (p.356). ${ }^{11}$
\end{abstract}

Além desses denominadores comuns, podemos também afirmar que as provocações do pós-modernismo incitam respostas muito próprias na classe artística de países subdesenvolvidos ou em desenvolvimento como, por exemplo, um tipo de ficção terceiromundista propensa à elaboração de alegorias específicas de cunho nacional, como argumentou Jameson em "Third-world Literature in the Era of Multinational Capitalism"

\footnotetext{
${ }^{10}$ Outras reflexões sobre os traços pós-modernos na arte e cultura brasileiras incluem os livros Uma literatura nos trópicos (SANTIAGO, 1978), Pós-modernidade (OLIVEIRA et al., 1988), Pós-modernidade e política (HOLLANDA, 1991), A provocação pós-moderna (MORICONI, 1994), o capítulo "Pós-modernidade: contraponto tropical”, de Luís Costa Lima, publicado no volume Pensando nos trópicos (LIMA, 1991); o artigo "Brazilian Culture: Nationalism by Elimination", de Roberto Schwarz (New Left Review, v.167, 1988).

11 hypertext in fiction, the media's universal presence as a common denominator for the production of subjectivities, pop language as a universal set of references for prospective aesthetic thought, the infinite proliferation of signs, the importance of rhetorics of paradox and paratactic syntaxes, the notion of multiple and fragmentary identities as well as the fragmentation of meaning: there are but a few elements that inhabit the postmodern imaginary in Brazil, as elsewhere.
} 
(1986, p.69), e, em nosso contexto, a possibilidade de movimentos pós-modernos brasileiros como a poesia marginal (MORICONI, 2005).

O crítico inglês Randal Johnson, no ensaio "Brazilian Narrative" (2004), observa que a prosa de Noll, assim como a de autores como Silviano Santiago, Sérgio Sant'Anna e Haroldo Maranhão, podem ser consideradas como exemplos de ficção pós-moderna brasileira em virtude de as narrativas desses escritores serem "fragmentadas, céticas e autorreflexivas" e por usarem expedientes como o pastiche, referenciais da cultura pop e o acentuado reaproveitamento de estilos e discursos literários do passado (p.133). Na opinião de Johnson, romances de Noll como A fúria do corpo, Harmada e Hotel Atlântico constituem exemplos de pós-modernismo no Brasil devido à maneira como buscam narrativizar a anomia existencial de personagens imersas em um mundo decadente e fragmentado (p.134).

A partir desses direcionamentos iniciais, desenvolvemos o presente trabalho, cuja estrutura está dividida em três capítulos. O primeiro deles compreende uma tentativa de delinear a identidade do conto pós-moderno a partir de uma diferenciação de práticas tradicionais e modernistas do gênero. A articulação dessas ideias é feita mediante análises de textos dos autores João Gilberto Noll e Sam Shepard, bem como de outros contistas, com o intuito de apontar caminhos que orientem a nossa investigação. O capítulo II dedica-se a um estudo de sujeitos e relatos com marcas de indeterminação percebidos em alguns textos do livro Mínimos, múltiplos, comuns, e ao refinamento de noções teóricas que fundamentam procedimentos ficcionais como a escrita paratática e as estruturas lacunares que frustram o processamento cognitivo do texto literário, cuja utilização contribui para instaurar indeterminações narrativas. O capítulo III volta-se para a investigação de procedimentos artísticos como rupturas textuais, dissociação de imagens e multiplicações / dissoluções identitárias, envolvidos na fragmentação de narrativas de Great Dream of Heaven e, por conseguinte, de noções iluministas e sociológicas de sujeito como um ente centrado, estável e completo.

Embora os capítulos II e III enfoquem cada um dos autores separadamente, nossas análises atuam no sentido de estabelecer relações entre a fortuna crítica e a produção textual de ambos os escritores, que voltam a ser abordados conjuntamente, como ocorre no capítulo I, na conclusão. 


\title{
Capítulo I
}

\section{INSTANTES FICCIONAIS: ALGUNS ASPECTOS DOMINANTES NO CONTO CONTEMPORÂNEO}

\begin{abstract}
[João Gilberto] Noll chamou suas narrativas mínimas de "instantes ficcionais", o que é apropriado [...]. 'Instante ficcional' denota a qualidade exponencial, visível, quase óbvia, do relato isolado: a maravilha do engenho que ergue sua construção minúscula com a complexidade estrutural intrínseca das catedrais.
\end{abstract}

Wagner Carelli, 2003

\begin{abstract}
O conto é um pequeno desvio maravilhoso. Você pode mergulhar em um conto de tal maneira que é diferente da escrita de uma peça teatral, mas você pode investir o mesmo tipo de força neles. Eu sempre gostei muito da forma do conto. Ela é muito vigorosa. É uma forma tão esplêndida e eu gosto de ficar trabalhando no conto porque sinto que tenho um caminho muito longo a percorrer. ${ }^{1}$
\end{abstract}

Sam Shepard, 2000

A maioria dos teóricos e autores que tenta definir as propriedades paradigmáticas do conto literário é forçada a reconhecer em algum momento a dificuldade de se caracterizar ou mesmo de esboçar uma definição desse gênero ficcional. Devido à sua maleabilidade formal e à relativa liberdade com que os autores têm lidado com esse tipo de texto, qualquer tentativa de classificá-lo, explicá-lo ou delimitá-lo tende a resultar incompleta diante de sua grande variedade. Por essa razão, esse trabalho busca não se ater a uma ou outra definição de conto, mas discutir e contrapor algumas características dominantes do gênero em determinados períodos. Em outras palavras, busca-se destacar quais aspectos são privilegiados e quais são relegados ao segundo plano na escrita de um conto, bem como quais são as implicações dessas escolhas em termos de efeitos de sentidos.

\footnotetext{
${ }^{1}$ The short story is a wonderful little side trip. You can go into a short story in such a way that it's not like writing a play but you can invest the same kind of force in them. I've always loved the form of the short story. It's very firm. It's such a wonderful form, and I like to keep working at it because I feel like I got such a long way to go (cf. ROUDANÉ, 2002, p.78).
} 


\subsection{O conto em sua acepção tradicional}

Em primeiro lugar, faz-se necessário apresentar a noção de conto tradicional utilizada neste trabalho: trata-se de uma nomenclatura homogeneizante, abrangendo diferentes tipos de narrativas breves, conforme as entendemos no atual contexto, cujas primeiras manifestações datam do início do século XIX, quando o impacto das narrativas míticas curtas de Hawthorne e Poe, nos Estados Unidos, e Nikolai Gogol, na Rússia, motivaram teóricos da literatura a se debruçarem sobre essa forma específica de contar histórias, e continuam até o advento do conto "moderno" (IFTEKHARRUDIN et al., 2003, p.vii, ix). Embora os vários tipos de contos tenham suas próprias preocupações estéticas e literárias, seu modo típico de construir a narrativa e de provocar determinadas interações com o leitor, é possível reconhecer traços dominantes comuns a muitos deles e, para fins de argumentação, somos forçados a agrupá-los sob a rubrica generalizante de contos "tradicionais", isto é, narrativas breves que concebem cenários, personagens e enredo de acordo com algumas convenções do gênero, primando, em maior ou menor grau, pela familiaridade estrutural do universo ficcional.

Esse investimento em favor da criação de um universo ficcional "familiar" consiste na adequação textual a rigorosos princípios formais. Dentre eles, destaca-se o fato de que o conto tradicional, cujo modelo pode ser considerado o de ação, deve buscar, via de regra, algum tipo de unidade temática, com limites e contornos fixos e precisos. Deve também primar pela sucessão mais ou menos linear de ações, pela gradação tensiva, pela exclusão de tramas secundárias e pela apreensão de uma única faceta de uma situação ou personagem (CORONADO, 1969-1970, p.26-38). Moisés (1975) sintetiza esses princípios da seguinte maneira:

Trata-se [o conto típico], pois, de uma narrativa unívoca, univalente. Constitui uma unidade dramática, uma célula dramática. Portanto, contém um só conflito, um só drama, uma só ação: unidade de ação. [...] O conto constitui uma fração dramática, a mais importante e a decisiva, duma continuidade em que o passado e o futuro possuem significado menor ou nulo. [...] De onde o conto ser, a essa luz, obra fechada, dramaticamente circunscrita (p.124-125). 
Outros princípios tradicionais do conto, em geral, incluem, além das unidades de tema e de ação, a redução tanto do lugar geográfico como do tempo a um âmbito restrito (Id., ibid., p.126). Dessa forma, as personagens do conto típico não costumam empreender grandes deslocamentos e a ideia ou "imagem da vida" captada pelo contista deve restringir-se a um curto lapso de tempo (Id., ibid., p.126). Além disso, Coronado (1969-1970) acrescenta que esses princípios orientam-se no sentido de privilegiar, no conto típico, o aproveitamento apenas de seres e fatos "paralelos à realidade pura" (p.26), evitando, assim, a incorporação de elementos feéricos ou sobrenaturais. Esses elementos "metarreais" — cuja significação simbólica ou alegórica tende a ajustar-se mais aos contos de fada ou aos contos maravilhosos - devem ser evitados, segundo o teórico, pelo contista tradicional, que necessita evitar a (con)fusão de níveis de realidades distintos em nome da manutenção da matéria fáctica "pura" (Id., ibid., p.26-28). Por essa razão, o conto tradicional deve servir-se de uma linguagem objetiva e somente utilizar "metáforas de curto espectro, de imediata compreensão para o leitor" (MOISÉS, 1975, p.129).

Além disso, as convenções literárias que regulam o conto tradicional têm definido que este deve contar uma história de preferência fictícia sem ultrapassar um certo limite temporal de leitura. Como sabemos, Poe sugeriu em A filosofia da composição (1846) que, para fins de gerar uma certa "unidade de efeito" ou "efeito preconcebido" sobre o leitor, esse limite não deveria exceder o período de uma "assentada". Caso o texto fosse muito grande e o leitor precisasse fazer pausas, essa ruptura e a consequente "invasão" dos afazeres do mundo real na mente do leitor poderiam diminuir ou arruinar o impacto causado pela unidade de efeito (2006, p.220-221). A partir dessa orientação de Poe, podemos inferir sua provável desaprovação a um conto demasiadamente breve, pois este não conseguiria prender a atenção do leitor pelo tempo necessário para criar nele interesse e expectativa. Dessa forma, sua atenção se dispersaria rápido demais e o efeito impactante sobre o público acabaria se perdendo. Por esse motivo, na visão de alguns teóricos como, por exemplo, Moisés (1975), “o contista não pode perder tempo em delongas, que enfastiariam o leitor", pois este estaria mais "interessado em logo invadir o âmago da história, com o fito de apreendê-la dum só fôlego" (p.143).

Discutida essa cláusula do tempo de leitura, restava ainda a questão do tamanho do texto em termos espaciais. Afinal, quantas páginas deve ter um conto típico para que não seja nem longo nem curto demais, podendo ser lido durante uma "assentada"? Smith (1902), na mesma corrente de Poe, delimita o conto em relação ao romance, sugerindo que aquele não 
exceda este em extensão, embora isso não resolva o problema, pois há romances breves, longos, divididos em tomos etc. Friedman (1989) sugere a resolução do problema da brevidade de maneira pragmática, isto é, "incluindo na subclasse conto todos aqueles trabalhos de 'ficção narrativa em prosa' que são considerados curtos por autores, pelo público leitor, editoras, críticos e estudiosos" (p.16, grifo nosso) ${ }^{2}$. Essa classificação flexível, oferecida por Friedman, que, em tese, aceitaria chamar de conto qualquer escrito breve de natureza ficcional e em prosa, obviamente não reflete as rígidas convenções seguidas por vários contistas e críticos tradicionais mais afeitos, segundo Susan Lohafer, ao "velho catecismo" do conto, isto é, a observância de regras mais ou menos invariáveis sobre um determinado tipo de tom, personagem e ambiente que deveriam ser obedecidas por todo "bom" contista (cf. LOHAFER \& CLAREY, 1989, p.5). Nesse sentido, Coronado (19691970) defende que, embora o conto típico não tenha de ser necessariamente curto, "seu caráter monotemático condiciona-o normalmente para a brevidade" (p.34).

Um outro aspecto dominante do conto tradicional diz respeito à importância dos acontecimentos, afinal, “o conto é um gênero fáctico, um gênero cuja matéria prima são fatos, algo que serve para 'relato', para 'conto"' (CORONADO, 1969-1970, p.24). Smith nota que a narração de incidentes é essencial, pois algo deve acontecer e conclui: "um conto sem uma sucessão de incidentes de algum tipo é inconcebível" (1902, p.3). Poe também ressalta a importância das ações, pois é por meio da causalidade inerente ao desenrolar desses acontecimentos que o leitor passa a ter interesse pela história e a esperar ansiosamente pelo seu desenlace (2006, p.219).

A questão do interesse do leitor, na opinião de Smith, também é criada e mantida pelo uso de seres ficcionais intrigantes, pois "uma variedade de personagens dá a vida e o fervor do interesse humano à história" (1902, p.4). ${ }^{4}$ Por esse motivo, e levando em conta a questão dos limites espaçotemporais do gênero, os contistas tendem a mostrar um número reduzido de personagens e a narrar em primeiro plano os breves incidentes envolvendo esses mesmos seres ficcionais. Personagens ou tramas secundárias, que encontram certo espaço em formas mais longas como o romance, devem ser deixadas para segundo plano ou mesmo excluídas

\footnotetext{
${ }^{2}$ including in the subclass short story all those works of 'narrative fiction in prose' that are considered to be short by writers, the reading public, publishers, critics, and scholars.

${ }^{3}$ a story without a succession of incidents of some kind is inconceivable.

${ }^{4}$ a variety of characters gives life and warmth of human interest to a story.
} 
totalmente no caso de uma narrativa como o conto (p.4). Moisés (1975) sintetiza essa noção nos seguintes termos:

O conto, portanto, abstrai tudo quanto, no tempo, encerre importância menor, para se preocupar apenas com o centro nevrálgico da questão. Isso implica que ao conto repugne a 'duração' bergsoniana ou a complicada inserção de planos temporais [...]. O conto caracteriza-se por ser 'objetivo', atual: vai diretamente ao ponto, sem deter-se em pormenores secundários. Essa 'objetividade' [...] salta aos olhos com as três unidades: de ação, lugar e tempo (p.127).

Aguiar e Silva (1973) atribui a esses dois fatores (acontecimento e personagem) um papel decisivo para a prosa de ficção, pois sua característica fundamental é o fato de ter "personagens situadas num determinado contexto, em certo lugar e em certa época, mantendo entre si mútuas relações de harmonia, de conflito, etc.”, e para que essas personagens sejam "reveladas" ao leitor, há a necessidade de uma "série de acontecimentos" interessantes e a possibilidade de o leitor reconstruir na mente a "história" como uma sucessão de fatos (p.238). Essa possibilidade de apreensão da sequencialidade de fatos é também reforçada por Moisés (1975), que conclui: “a trama [do conto] se organiza segundo um andamento semelhante ao ritmo com que as coisas acontecem na vida, e os pormenores vão-se acumulando numa ordem 'lógica' de fácil percepção" (p.133, grifos nossos).

Quanto aos desenvolvimentos posteriores do gênero, podemos afirmar que a virada realista provocou mudanças sensíveis na forma do conto tradicional. Autores como Honoré de Balzac, Guy de Maupassant, Mark Twain, Stephen Crane, Henry James e Joseph Conrad, entre outros, e, no contexto lusófono, sobretudo, Machado de Assis e Eça de Queirós, foram os responsáveis pela introdução de uma narração mais objetiva, com especial atenção aos detalhes do cenário e à influência da conjuntura socioeconômica sobre as ações das personagens. A importância de prender a atenção do leitor intensifica-se, sobretudo no contexto norte-americano, em virtude de existir, nessa época, um crescente número de folhetins e de outros periódicos populares que ofereciam essas histórias a um público leitor, cuja preferência literária residia na linearidade do enredo, nas ações estabelecidas de acordo com padrões causais coerentes, e que levasse a uma resolução (IFTEKHARRUDIN, 2003, p.ix).

Essa importância das sequências de ações que formam um enredo se consolidou, sobretudo, a partir das histórias de detetives. Segundo Suzanne Ferguson (1989), esse tipo de 
conto de enredo ou de ação, com sua ênfase na história, cria certa cumplicidade entre narrador e leitor: àquele cabe narrar um padrão inteligível de eventos, omitindo algumas informações, deixando certas "pontas soltas" e semeando algumas pistas; ao leitor cumpre completar, inferir e juntar esses elementos e construir significados a partir do enredo. A autora sugere ainda que, nesse tipo de conto de enredo tradicional, esses elementos omitidos, embora nunca contados de fato na história, compõem um esquema familiar facilmente dedutível e são fornecidos de maneira tácita pelo autor (p.188-189). Moisés (1975), referindo-se ao conto típico, argumenta que "nada deve escapar ao leitor desse gênero de ficção, sempre desejoso de apreender prontamente os fatos, e passar para outra narrativa igual" (p.129).

Embora muitas das ideias expostas até aqui sejam questionáveis, como veremos, quando pensamos na ficção contemporânea, há casos de escritores e críticos atuais, cuja postura é bastante semelhante. O contista John Gardner (1994), por exemplo, apresenta-nos a seguinte explicação:

\begin{abstract}
Uma verdadeira obra de ficção é uma coisa maravilhosamente simples — de tal simplicidade que a maioria dos chamados escritores sérios evita tentar, por sentirem que devem fazer algo mais importante e engenhoso, sem nunca pensar o quão difícil é isso. Uma verdadeira obra de ficção faz todas as coisas a seguir, e as faz de maneira elegante, eficiente; ela cria um sonho vívido e contínuo na mente do leitor; ela é implicitamente filosófica; ela satisfaz ou ao menos lida com todas as expectativas que instala; e ela nos atinge, ao final, não apenas como uma coisa feita, mas como uma brilhante performance (p.223). ${ }^{5}$
\end{abstract}

Como podemos perceber, algumas dessas convenções deixam clara a preocupação em mobilizar os elementos da narrativa a fim de provocar na mente do leitor determinada impressão, seja ela a "unidade de efeito" de Poe ou o "sonho vívido e contínuo" de Gardner. Além dessa preocupação, dominante na narrativa breve do estilo gótico de Poe até a contemporaneidade de Gardner, essas formulações mostram um tipo de conto que tenta

\footnotetext{
${ }^{5}$ A true work of fiction is a wonderfully simple thing - so simple that most so-called serious writers avoid trying it, feeling they ought to do something more important and ingenious, never guessing how incredibly difficult that is. A true work of fiction does all of the following things, and does them elegantly, efficiently; it creates a vivid and continuous dream in the reader's mind; it is implicitly philosophical; it fulfills or at least deals with all of the expectations it sets up; and it strikes us, in the end, not simply as a thing done but as a shining performance.
} 
apelar para o intelecto do leitor e para sua capacidade de (re)conhecer-se nas personagens da ficção. A partir dessa identificação inicial, o leitor passaria então, de modo genérico, a interessar-se por suas vidas e, em um curto espaço de tempo, desvendar a sequência dos acontecimentos narrados, acumular o conhecimento desses fatos, nutrir expectativas e chegar a uma resolução mais ou menos satisfatória para a história. Ainda nos primeiros anos do século XX, Smith, por exemplo, acreditava que reter o conhecimento adquirido ao relacionar um fato com uma rede de outros fatos narrados constitui um dos "prazeres da mente" e que, portanto, existe a necessidade de o conto investir em valores como unidade, harmonia, coerência e clareza (1902, p.3-4).

Um outro tipo de narrativa breve desenvolveu-se de maneira concomitante ao conto de ação durante o realismo. Essa variante tentava chamar a atenção do leitor das grandes cidades para a "cor local", isto é, as relações sociais ou as peculiaridades do meio-ambiente de um determinado lugar pouco conhecido. Sem dar tanta ênfase aos acontecimentos em si, esse tipo de narrativa tende a criar cenários e atmosferas tão ricas que são capazes de sugerir ao leitor ideias, estados de espírito e sentimentos das personagens que protagonizam as

histórias. Para Fergusson (1989), esses chamados gêneros populares de narrativa, como o conto policial ou de detetive e o conto de "cor local", são a chave para os desenvolvimentos posteriores do gênero, sobretudo os do conto moderno.

Após esse breve levantamento de preocupações estético-formais do conto tradicional, contemplamos, a seguir, alguns aspectos dos desenvolvimentos desse gênero sob influência de diferentes vertentes modernistas, ressaltando o fato de que o fazemos segundo a maneira como as angulações teóricas mais recentes tendem a examinar em retrospecto esse legado estético e cultural.

\subsection{O conto moderno}

A partir das diversas influências exercidas pelas correntes estéticas modernistas, pode-se dizer que o conto, gênero antes relegado a uma posição subalterna no cânone, ganhou, em diversos países, sobretudo em finais do século XIX e nas décadas iniciais do XX, a devida atenção tanto de autores quanto da crítica e passou a incorporar estratégias bem mais sofisticadas (FERGUSON, 1989, p.191). Dentro de um breve panorama da contística 
ocidental, podemos destacar alguns nomes, cuja produção, independentemente da filiação a determinadas literaturas nacionais, tem sido considerada responsável pela inovação de diversos aspectos do próprio gênero, conforme abordaremos a seguir:

Anton Tchekhov, por exemplo, ao tentar conter os excessivos comentários sociológicos de alguns contos realistas e naturalistas, provocou uma reinvenção do gênero, utilizando narradores que se restringem a apresentar os detalhes banais da vida cotidiana, sem interpretá-los diretamente (cf. BROWN, 1989, p.246). Embora a "objetividade" criasse a ilusão de que os narradores evitassem comentar ou julgar as situações, as cartas de Tchekhov deixam claro que a manipulação e seleção implícitas de determinados elementos servia a um plano consciente do autor, que, de certa forma, "direcionava" o leitor a interpretá-los de determinado modo (BLAISDELL, 2004).

Além de Tchekov, vários outros contistas contribuíram de diferentes formas para o gênero: James Joyce, com o "ciclo de histórias" Dubliners (1914), desenvolve uma intensa conexão psicológica entre narrador, personagem e leitor, materializada sob a forma de epifanias (IFTEKHARRUDIN et al., 2003, p.ix). Katherine Mansfield é responsável, ao lado de Virginia Woolf, por imaginar uma escrita feminina, na qual voz narrativa e voz autoral imbricam-se em um texto ao mesmo tempo banal e complexo (BENNETT, 2002, p.3), em que há a codificação de uma segunda história nas entrelinhas da primeira (LOHAFER \& CLAREY, 1989, p.214-215).

Assim como Joyce disseca as mazelas dos dublinenses em Dubliners, Sherwood Anderson busca, em especial em Winesburg, Ohio (1919), plasmar as deformidades tanto físicas quanto morais da cidadezinha americana por meio de contos ricos em termos de "cor local" e experimentações formais (RULAND \& BRADBURY, 1991, p.230, 281-282), que exploram aspectos grotescos do universo ficcional e criam associações imagéticas capazes de sugerir as complexidades dos dilemas éticos e sexuais das personagens que animam as histórias (ELLIS, 1993; HANSEN, 1997).

Ernest Hemingway demonstra em contos como "A Clean Well-Lighted Place" (1926), "Hills Like White Elephants" (1927) e “The Killers” (1927), por exemplo, o domínio teórico e prático de uma escrita bastante econômica, quase isenta de adjetivos. Por meio de uma profunda carga imagética, o autor busca chamar a atenção do leitor para o não dito, mas que pode ser inferido a partir do texto (RULAND \& BRADBURY, 1991, p.303-305). Embora a escrita econômica de Hemingway, embasada em sua "teoria da ponta do iceberg" (cf. 
MORELAND, 2000), tenha influência direta sobre alguns desenvolvimentos do conto pósmoderno, como, por exemplo, a vertente minimalista, ${ }^{6}$ Moreland ressalta que a "parte submersa do iceberg", isto é, os elementos omitidos da narrativa, devem estar claros para o autor e, muitas vezes para o leitor, caso contrário, criam-se lacunas na história. Em outras palavras, assim como o "efeito preconcebido" idealizado por Poe, para Hemingway, os dados omitidos devem ter sido previamente concebidos pelo autor. No entanto, alguns desenvolvimentos do conto contemporâneo violam essa "regra" e criam justamente essas lacunas, ou seja, investem em zonas indeterminadas e de sentido ou compreensão obscuros para o leitor e, muitas vezes, para o próprio autor.

No contexto brasileiro, Mário de Andrade, com Contos novos (publicados postumamente em 1947, mas elaborados desde a década de 20), é responsável por repensar e "deformar" o conto como gênero, por meio de diálogos com as tradições literárias brasileira e europeia e a incorporação de elementos ditos não literários como a técnica musical e o folclore, em uma tentativa de redefinir o papel crítico do intelectual modernista e de representar a "totalidade social da cultura brasileira das primeiras décadas do século XX" (cf. MAJOR NETO, 2001). Conforme suas correspondências com Drummond deixam claro, Mário de Andrade era adepto de uma concepção muito própria de conto (Id., ibid., p.22-33), fato que o levou a elaborar talvez a fórmula mais flexível para definir o gênero: "Em verdade, sempre será conto aquilo que seu autor batizou com o nome de conto" (2002, p.9-12).

Digna de nota é também a contribuição de Clarice Lispector, cujas narrativas breves, coligidas, por exemplo, em Laços de família (1960), emergem saturadas de uma sofisticada carga simbólica, sobretudo envolvendo animais, que servem como projeções imagéticas dos

\footnotetext{
${ }^{6} \mathrm{O}$ termo minimalismo costuma ser aplicado às artes plásticas (Frank Stella, Donald Judd, Sol LeWitt, Carl Andre etc.), à música (John Cage) e ao design (Mies van der Rohe) para identificar uma tendência geral à simplificação e à redução dos elementos constitutivos do objeto artístico a parâmetros mínimos. Outras características do minimalismo (ou Minimal Art), sobretudo em pintura, referem-se à composição de telas, esculturas e instalações a partir de formas geométricas básicas e imagens abstratas, cujo estilo tende a ser impessoal e repetitivo (KARMEL, 2004, p.90-101). O termo minimalismo tem sido também associado à literatura para designar, em especial, a produção de contos de autores como Raymond Carver, Jay McInerney, Tobias Wolff, Bobbie Ann Mason, Frederick Barthelme, entre outros (cf. BARTH, 1995). Algumas características frequentemente atribuídas ao minimalismo literário, conforme abordamos na seção 1.4 deste trabalho, incluem a acentuada simplificação vocabular, a criação de frases concisas e impessoais, a eliminação de quaisquer traços que possam sugerir sentimentalidade ou emoção, além da busca por um esvaziamento de possíveis sentidos poéticos ou metafóricos atribuídos à palavra (cf. CALABRESE, 1999, p.185; GREGSON, 2004, p.142). O conto tem sido apontado como o gênero minimalista por excelência em virtude de sua propensão tanto à brevidade quanto à redução da totalidade de uma determinada experiência a fragmentos mínimos (GREGSON, 2004, p.142; SOBREIRA, 2005, p.46-99).
} 
dilemas vivenciados pelas personagens, em especial, do gênero feminino. Por meio de narrativas densas e introspectivas, Clarice examina essas mulheres, em geral aprisionadas em seus papéis sociais convencionais, frequentemente acometidas por uma dolorosa percepção de si mesmas como objetos e não como sujeitos de suas próprias existências (WHEELER, 1987).

Embora as omissões sejam muitas, diversos outros autores como Graciliano Ramos, Guimarães Rosa, e outros menos "canônicos", buscam revitalizar o gênero por meio de inovações técnicas e formais, forjando escritas singulares, dotadas de estilos únicos, em uma constante tentativa de plasmar ficcionalmente experiências e situações desconcertantes vivenciadas no contexto sociocultural moderno. Lyotard (1993), no entanto, defende a ideia de que os modernistas, de modo geral, apesar de imersos em experiências, que classifica como "irrepresentáveis", características dessa época, são capazes de preservar em suas narrativas um tipo de unidade discursiva, uma consistência formal, que "continua a oferecer ao leitor ou expectador matéria para consolo e prazer" (p.46). ${ }^{7}$

O conto, por uma série de razões, incluindo a brevidade, a necessidade de conquistar o leitor, entre outras, talvez seja uma das formas mais preocupadas com atingir uma unidade discursiva por meio de uma apurada consistência formal. Essa preocupação torna-se muito evidente quando examinamos o que os teóricos do conto e os próprios contistas, sobretudo Tchekhov, Anderson e Hemingway, têm a dizer sobre o extremo rigor envolvido no processo criativo do gênero (cf. MORELAND, 2000; BLAISDELL, 2004).

Por essa razão, vários teóricos têm destacado a importância de o artista "lapidar" seu texto, eliminando sempre que possível os excessos e os traços confusos ou improvisados, pois estes podem comprometer a continuidade do efeito de sentido na mente do leitor. Cortázar (1974), por exemplo, postula que o conto deve ser trabalhado em profundidade, em sentido vertical, a fim de mobilizar seus elementos constitutivos de tal forma a provocar uma "explosão" no ânimo do leitor, um impacto capaz de abrir "de par em par uma realidade muito mais ampla” (p.151). Dessa forma, o contista deve, como notamos acima nas palavras de Gardner, instalar e satisfazer as expectativas do leitor — isto é, fornecer-lhe "a matéria para consolo e prazer" de que fala Lyotard - e, se possível, atingi-lo com sua "brilhante performance" (GARDNER, 1994, p.223). Para tanto, o equilíbrio da narração, a coerência da

\footnotetext{
${ }^{7}$ continues to offer to the reader or viewer matter for solace and pleasure.
} 
narrativa e, sobretudo, a relativa clareza da motivação das personagens devem ser ressaltados, conforme observa Rust Hills no livro Writing in General and Short Story in Particular (1977):

o autor é no final das contas responsável em relação ao leitor, embora esta responsabilidade seja em geral negada. O autor deve explicar ao leitor por que a personagem toma um caminho em vez do outro - deve explicar ou mostrar por meio da ação do enredo o motivo pelo qual a personagem escolheu um determinado caminho ou como ele foi forçado a tomá-lo pelas circunstâncias ou por outras personagens - e o autor deve deixar claro que aquela era uma estrada bastante diferente $\left(2000\right.$, p.6). ${ }^{8}$

A crítica atual contra esse tipo de ênfase no papel do autor como responsável pelo aperfeiçoamento de todos os componentes da "olaria" do conto aponta que, ao trazer para o primeiro plano valores como clareza, coerência e domínio, quaisquer outros aspectos da criação literária que não contribuam diretamente para o fechamento desse "caracol de linguagem" (cf. CORTÁZAR, 1974, p.149) voltado para o centro de si mesmo são relegados para segundo plano ou tratados como "anomalias". Além disso, as teorias que embasam essa proposta de narrativa pressupõem a existência do autor como uma "analogia de deus" (McHALE, 1987, p.29), ${ }^{9}$ que, em sua superioridade, ocupa uma instância privilegiada, de onde organiza os mínimos detalhes de seu universo ficcional e exerce absoluto controle sobre suas personagens. Embora essas teorias vislumbrem, especialmente a partir do modernismo, um leitor participante, que é capaz de reconfigurar os elementos fragmentários do heterocosmo narrativo a fim de obter um significado a partir das combinações possíveis, o leitor conta com um plano geral pré-definido por esse autor "onipotente", que, na maior parte das vezes, tende a satisfazer ou ao menos levar em consideração as expectativas criadas.

Por valorizar questões de ordem cognitiva, fica clara, portanto, a existência de um componente epistemológico em foco nas formas tradicionais e modernas do conto literário, o que não exclui a vertente ontológica, mas apenas a desloca para um segundo plano. Essa

\footnotetext{
${ }^{8}$ the author is ultimately responsible to the reader, although this responsibility is often denied. The author must explain to the reader why a character took one road instead of the other - must explain or show by the action of the plot why the character chose a particular road or how he was forced into it by circumstances or other characters - and the author must make clear that it was a significantly different road.

${ }^{9}$ Castro (2002) apresenta argumento similar, segundo o qual, o narrador, pela perspectiva tradicional, é entendido como "homologia do agir de Deus" (p.61).
} 
afirmação está embasada em McHale (1987), que reconhece nas principais formas narrativas que antecedem o pós-modernismo a emergência de elementos de caráter predominantemente epistemológico (p.6-8,10).

Sem adiantar questões referentes à epistemologia e à ontologia, pois estas serão retomadas na seção 1.5 e na conclusão deste trabalho, cabe mencionar que o termo epistemologia, de maneira geral, refere-se à preocupação filosófica com a origem, os fundamentos, as possibilidades e a abrangência do conhecimento. Como uma teoria geral da ciência e do saber, a epistemologia tem motivado muitos filósofos, ao longo dos séculos, a tentar determinar quais os métodos e processos envolvidos na forma como o sujeito indagativo estabelece relações cognitivas com a alteridade objetiva (cf. BUNNIN \& YU, 2004, p.218-219; HONDERICH, 2005, p.260-265). Muitos desses questionamentos filosóficos, sobretudo durante a chamada "era da epistemologia" (séculos XVII e XVIII), caracterizam-se por uma busca por certezas. Essa noção muitas vezes tem sido associada a Descartes, cujas doutrinas e indagações filosóficas versavam sobre a busca por "uma base segura para o conhecimento" (HONDERICH, 2005, p.260). ${ }^{10}$ No âmbito literário, o teórico Brian McHale defende a tese de que "a dominante da ficção moderna é a epistemologia", pois parte substancial das narrativas modernas favorecem questões relacionadas ao conhecimento e à interpretação do mundo (1987, p.9). Embora estes níveis epistemológicos de interação com o universo impliquem fraturas e impasses, a acessibilidade, a confiabilidade e a circulação do conhecimento e da interpretação dos elementos que compõem o universo ficcional (ou o próprio real) ainda contam com "um centro de consciência" ou algum modelo relativamente estável de processamento cognitivo na prosa moderna (Id., ibid., p.9-10). McHale acrescenta que o conto de ação e as narrativas policiais ou de suspense - com sua sequencialidade linear de fatos, seus enigmas, pistas e mistérios, que exercitam a dedução lógica do leitor - mostram com clareza a presença da dominante epistemológica (Id., ibid., p.9-10).

Quanto ao termo ontologia, este tem sido utilizado para identificar o ramo da metafísica responsável por estudos da natureza do ser e da existência. As preocupações centrais da ciência ontológica dizem respeito a indagações sobre o que é a existência, quais seres realmente existem e em quais categorias, caso estas existam, poderíamos distinguir as

\footnotetext{
${ }^{10}$ sure foundation of knowledge.

${ }^{11}$ the dominant of modernist fiction is epistemological.
} 
coisas existentes. Outras questões incluem pensar sobre do que é constituída a identidade de um objeto e quais são os níveis de existência (ou níveis ontológicos) dos seres (cf. BUNNIN \& YU, 2004, p.491; HONDERICH, 2005, p.670-671). Tendo em vista o enfoque ontológico envolvido nas sondagens literárias dos chamados "mundos do ser", McHale (1987) argumenta que, mais do que acumular evidências e fazer deduções sobre os fatos narrados, ao interagir com algumas narrativas pós-modernas, as questões que primeiro atingem o leitor são: "qual é o modo de existência do mundo (ou mundos) que [o texto] projeta?; Como um mundo projetado [pela ficção] estrutura-se?" (p.10). ${ }^{12}$ Esses questionamentos devem-se à hipótese de que tanto o sujeito humano quanto o(s) universo(s) ficcional(is) projetados por alguns textos pós-modernos caracterizarem-se pela falta de unidade, isto é, por diversos níveis de fragmentações físicas e psíquicas. Lima (2000), em “Traços pós-modernos da ficção portuguesa actual”, atribui a recorrência da dominante ontológica em alguns textos pósmodernos aos seguintes fatores:

O sujeito racional e unitário perde a sua segurança epistemológica, a sua autoconsciência axiológica e questiona-se do ponto de vista ontológico; torna-se frágil, débil, na expressão de [Gianni] Vattimo, e a par dessa transformação, assiste-se à erosão do princípio da realidade: a realidade deixa de ser uma só, ou deixa mesmo de ser [...], torna-se plural, caótica, oscila, abre-se a um mundo de possiveis (p.1-2, grifos nossos).

Feito esse breve levantamento de alguns dos componentes centrais da dominante epistemológica dos contos tradicionais e modernos, é oportuno tratar a seguir de aspectos focalizados pelos contistas em resposta às provocações e à conjuntura sociocultural da pósmodernidade.

\footnotetext{
${ }^{12}$ what is the mode of existence of the world (or worlds) it projects?; How is a projected world structured?
} 


\subsection{O conto pós-moderno}

Em primeiro lugar, devemos esclarecer que, devido ao fato de estarmos ainda vivenciando a emergência do pós-modernismo, torna-se extremamente difícil estabelecer em qual momento preciso ocorreu a transição entre modernismo e pós-modernismo. Segundo os principais teóricos desse novo período, a passagem deu-se a partir da década de 1960, quando as sociedades avançadas experimentaram a entrada do capitalismo em seu terceiro estágio de desenvolvimento (JAMESON, 2006, p.22-23).

Ainda que aspectos associados ao pós-modernismo possam ser observados desde os “contos” filosóficos de Jorge Luís Borges (cf. McHALE, 1987; CONNOR, 2004, p.74), grande parte dos críticos tendem a situar essa possível emergência do chamado conto com feições pós-modernas a partir da década de 1970. É o caso, por exemplo, de Richard Ruland e Malcolm Bradbury, que identificam traços pós-modernos no conto norte-americano, em especial nos textos de Donald Barthelme publicados na revista The New Yorker (1991, p.390). Outros contistas associados à fase emergente do pós-modernismo nos Estados Unidos são Richard Brautigan (Id., ibid., p.390) e Raymond Carver (GREGSON, 2004, p.138-146). Quanto ao âmbito da literatura brasileira, aspectos pós-modernos, como já mencionamos na Introdução, têm sido associados a contistas tão diversos quanto Silviano Santiago, Haroldo Maranhão e João Gilberto Noll (cf. JOHNSON, 2004, p.133-134).

Os teóricos citados nas seções anteriores têm razão ao definir algumas daquelas propriedades como traços dominantes do gênero conto durante determinado período da história literária, isto é, mais ou menos entre o romantismo e o modernismo. Porém, a partir do pós-modernismo, alguns dos principais teóricos contemporâneos descrevem uma mudança cultural (cf. McHALE, 1987, p.10-11; JAMESON, 2006, p.78-79, entre outros) que passa a ser mais orientada, como veremos, em favor da dominante ontológica. Desse modo, uma geração de contistas contemporâneos tende a incorporar em seus trabalhos, além de alguns dos valores anteriormente citados, aspectos indeterminados e a compor contos sem história, carentes de gradação tensiva, sem um padrão sequencial de ações palpáveis ou de estados definidos, desprovidos de resoluções e que resistem ao processamento cognitivo dos elementos narrativos em um sentido elucidativo do enredo. Encontramos alguns exemplos dessas possibilidades de textualização, por exemplo, em contos recentes de Sam Shepard e João Gilberto Noll. 
Dentro da complexa rede de sistemas que formam o livro Mínimos, múltiplos, comuns, de Noll, há um subsistema chamado "Nada", que se abre em mais dois subconjuntos: "Nadas" e "Ninguéns". Neste último subsistema, há um texto de pouco mais de cem palavras denominado "Ninguém", que transcrevemos a seguir na íntegra:

Havia um olhar sem dono flutuando entre os móveis e o lustre... entre os quadros e o pó que uma faixa de sol alumiava. De fato, havia por ali um olhar submerso, meio entorpecido talvez por uma preciosa compaixão de tudo e nada, invisível por entre pupilas esfuziantes, diria que espumantes. Esse olhar parecia uma inseminação atávica naquela reunião de ilustres. Dominado por seu apelo vago, entrei no banheiro para lavar as mãos, não sei... como que para selar o surto de exclusão que me acendia. Vi um corpo a se banhar atrás da cortina. "Quem é?", escutei. Balbuciei: "Ninguém". E fui me esgueirando para a porta de serviço (2003a, p.32).

Consciente de que muitos leitores acabariam experimentando dificuldades em interagir com as numerosas camadas de sistemas e subsistemas do livro, o editor Wagner Carelli ${ }^{13}$ optou por colocar um "mapa" desses hipercontextos, explicando como essas estruturas se "encaixam", e uma nota explicativa sobre a lógica essencial da edição no início do volume a fim de nortear de certa forma a leitura. Estratégia semelhante foi adotada pela escritora Karen Tei Yamashita no romance Tropic of Orange (1997) para "orientar" seus leitores a lidarem com as aventuras de suas sete personagens ao longo de uma semana em cidades do México e em Los Angeles. Ao contrário do mapa de Yamashita, que é compacto e ocupa duas páginas do livro, o "mapa" de hipercontextos de Mínimos, múltiplos, comuns está disposto ao longo de doze páginas. Devido ao detalhamento do modo como os subsistemas de microcontos inserem-se dentro de sistemas temáticos, o "mapa" de Carelli acaba se mostrando tão disfuncional quanto os mapas descritos por Jorge Luis Borges em "Del rigor en la ciencia" (1960), que, por fazerem uma representação cartográfica tão minuciosa de um

\footnotetext{
${ }^{13}$ Wagner Carelli é repórter, editor de livros e revistas, tendo já atuado na chefia de redação de publicações como República e Bravo! Atualmente dirige sua própria editora, a W11, responsável pelo lançamento de diversas obras de Noll, bem como de outros autores. No caso de Mínimos, múltiplos, comuns, Carelli, além de selecionar e ordenar os textos do escritor gaúcho, trabalhou na elaboração dos hipercontextos nos quais se inserem esses escritos. Por essa expressiva participação, pode-se afirmar que o editor exerceu coautoria em relação ao material, originalmente publicado por Noll em jornal.
} 
império, acabam tornando-se do tamanho exato do império e tendo de ser descartados devido à falta de praticidade. Dessa forma, o mapa e a nota explicativa de Mínimos, múltiplos, comuns podem ser vistos como uma tentativa de organizar a multiplicidade de textos. Uma outra leitura possível, entretanto, é a de que "estos mapas desmesurados", para emprestarmos a frase de Borges, constituem um comentário irônico sobre a inutilidade, na prática, dessa organização esquemática.

\subsection{1. - A problemática das dimensões físicas}

Quanto ao texto "Ninguém", reproduzido acima, partidários de uma visão mais tradicional do gênero conto relutariam em classificá-lo como tal, entre outros motivos, pelo fato de ser curto em excesso, isto é, um "instante ficcional" breve demais para desenvolver no leitor expectativas quanto ao desfecho e de nutri-las em um crescendo até alcançar um efeito impactante. Carelli (2003) observa que os textos de Mínimos, múltiplos, comuns não podem ser chamados de contos, pois crê que neles não há a "fixação breve de um momento preciso, com ênfase transcendental no que não é dito" (p.19) e, por essa razão, o crítico prefere chamar esses textos (com no máximo 130 palavras cada) de "romances integrais reduzidos a seu mínimo enunciado formal” (p.20).

$\mathrm{O}$ argumento de que os microcontos de Noll sejam incapazes de enfatizar a transcendência do não dito contraria as palavras do próprio autor, cuja declaração à Folha de S. Paulo destaca a atividade de produção dos textos de Mínimos, múltiplos, comuns como uma tentativa de "exercitar esse desejo de superação, de transcendência", porém, em um sentido diferente do espiritual, pois o autor não acredita que "o homem seja anjo" (MARCHEZAN, 2006, p.231). Ora, se não se trata de uma superação de ordem divina, Noll provavelmente está se referindo ao fato de seus microcontos evitarem explicações totalizantes e serem de tal maneira condensados que cabe ao leitor buscar em si mesmo, em seu próprio universo de relações, isto é, para além do texto como realidade material, uma interpretação provisória ou contextual, que não é "totalizada" na referida narrativa.

Em estudo de Mínimos, múltiplos, comuns, Marchezan (2006) não adota a nomenclatura proposta por Carelli e, apesar de se referir aos textos como contos, sugere o termo "hipotexto" para tentar definir as narrativas da coletânea. Segundo Marchezan, "um 
hipotexto é um texto muito curto. A brevidade, quer para a prosa ou para a poesia, provoca numa narrativa uma forte tensão interna. A brevidade intensifica, no caso de uma narrativa em prosa, uma coerção interna para o estabelecimento da sua trama” (2006, p.233).

Não acreditamos, no entanto, que a dimensão reduzida sirva de argumento suficiente para excluir esse tipo de texto do gênero conto. Há inclusive coletâneas de contos com textos ainda menores como, por exemplo, "The Scarlatti Tilt" (1971), de Richard Brautigan, composto de apenas duas frases carregadas de possíveis desdobramentos e sugestões de sentidos:

- É muito difícil morar em uma quitinete em San Jose com um homem que está aprendendo a tocar violino. Foi o que ela contou à polícia quando entregou a eles o revólver vazio (p.50). ${ }^{14}$

Jerome Sterne (1996), por exemplo, afirma que narrativas minúsculas como essas podem ser consideradas contos (short stories) e não apenas narrações breves. O autor inclusive editou uma coletânea de histórias de dezenas de autores americanos contemporâneos como Amy Hempel e Sam Shepard, chamada Microfiction: An Anthology of Really Short Stories (1996) ${ }^{15}$ com narrativas de igual ou menor dimensão que "Ninguém", de João Gilberto Noll. Sam Shepard também é adepto dos contos brevíssimos como, por exemplo, "Guadalupe in the Promised Land" (SHEPARD, 1981, p.30; STERNE, 1996, p.122-123), "You I Have No Distance From", do livro Cruising Paradise (1996a, p.66) e "Convulsion", da coletânea Great Dream of Heaven (2002a, p.95-96).

Além disso, como observa Steven Millhauser (2008) em recente ensaio, a constante busca pela condensação faz parte da "índole" do conto como gênero e o autor acredita que em seus desenvolvimentos mais atuais, o conto contemporâneo tende a tornar-se ainda mais breve, pois este

\footnotetext{
14 “It's very hard to live in a studio apartment in San Jose with a man who's learning to play the violin." That's what she told the police when she handed them the empty revolver.

${ }^{15}$ Há várias antologias dedicadas aos contos curtíssimos. Vejam-se, por exemplo, Os cem menores contos brasileiros do século (2004), organizados por Marcelino Freire, bem como Sudden Fiction (1993) e New Sudden Fiction: Short-Short Stories From America and Beyond (2007), editadas por Robert Shapard e James Thomas. A coletânea The World's Shortest Stories (1998), editado por Steve Moss, contém textos de até 55 palavras cada e uma introdução sobre os limites físicos desse gênero, ilustrada com uma tira de Charlie Brown, do cartunista Charles Schultz, em que a personagem Lucy implora a Lino que lhe conte uma história. Irritado, Lino brinda-lhe com a seguinte "pérola" de brevidade: "Um homem nasceu. Viveu e morreu. Fim” (1998, p.7).
} 
regozija-se em sua brevidade. Ele deseja ser ainda mais breve. Deseja ser uma única palavra. Se pudesse encontrar essa palavra, se pudesse proferir essa sílaba, o universo inteiro explodiria a partir dela em um rugido. Essa é a ambição abusiva do conto, essa é sua mais profunda fé, essa é a grandeza de sua insignificância (p.31, grifos nossos). ${ }^{16}$

Se, por um lado, reconsideramos os limites mínimos do conto, por outro, deveríamos rever, ao menos em tese, as prescrições quanto às dimensões máximas do gênero. $\mathrm{O}$ estabelecimento de uma dimensão máxima para o conto é ainda mais problemático, pois acabamos entrando em um campo nebuloso, em que há o risco de ultrapassar as fronteiras da novela e do romance. Jarrel (2003) lida com essa mesma problemática ao rever, pelo viés das teorias pós-modernas, o texto "June Recital", de Eudora Welty. Incluído na coletânea de contos The Golden Apples (1949), o relato ocupa cerca de oitenta páginas, iniciando-se com um tipo de estrutura própria ao conto, mas acaba por acionar características narrativas romanescas como mudanças de foco narrativo e longas digressões, sem, contudo, encaixar-se na categoria novela (JARREL, 2003, p.4-5). Talvez, por essa razão, alguns críticos prefiram não tentar definir o conto em termos das dimensões físicas, pois, "no que se refere à classificação [o conto] é uma das formas mais ardilosas. É questionável, de qualquer maneira, se a classificação é útil” (CUDDON, 1999, p.815). ${ }^{17}$

Como a classificação do que seja conto ainda é alvo de disputa, uma possibilidade, sugerida por Friedman (1989, p.16), é a de verificar se o livro traz algum subtítulo, informação ou anotação sobre a que gênero pertence. No caso de Great Dream of Heaven, de Shepard, tanto a folha de rosto quanto a quarta capa do livro, seja no original ou na tradução para o português, trazem a informação de que se tratam de contos. Porém, em se tratando de Mínimos, múltiplos, comuns, de Noll, a questão é um pouco mais difícil, pois o prefácio de Carelli sugere, como referimos, chamar os textos de "romances reduzidos". No entanto, em termos estritamente técnicos, a informação contida na ficha catalográfica do livro,

\footnotetext{
${ }^{16}$ It exults in its shortness. It wants to be shorter still. It wants to be a single word. If it could find that word, if it could utter that syllable, the entire universe would blaze up out of it with a roar. That is the outrageous ambition of the short story, that is its deepest faith, that is the greatness of its smallness.

${ }^{17}$ When it comes to classification this is one of the most elusive forms. It is doubtful, anyway, whether classification is helpful.
} 
sistematizada pela Câmara Brasileira do Livro, dá conta de que Mínimos, múltiplos, comuns é uma coleção de "contos brasileiros".

\subsection{2 - Dissociações dos seres ficcionais}

Leitores mais afeitos à forma tradicional do conto provavelmente estranhem também a relativa dissociação de imagens oferecidas pelo narrador de "Ninguém", sobretudo, o uso de um olhar dissociado de um corpo, a flutuar em um espaço indicado de modo incerto. Ainda que pouco detalhadas, há mudanças de estado, isto é, conteúdo narrativo no texto: o olhar se desloca e assume um tom de "apelo vago"; o "eu" assiste aos movimentos do olhar, capta-lhe o leve apelo, vai ao banheiro, vê uma pessoa se banhando etc. Contudo, em termos convencionais, não há um padrão rigoroso e coerente de acontecimentos, isto é, o texto não oferece explicações facilmente acessíveis para algumas das ações mínimas narradas como, por exemplo, o que motiva o "eu" a ser "dominado" pelo olhar se ele já o havia descrito como meramente vago? Além disso, os incidentes narrados são tão banais que dificilmente ocupariam o primeiro plano de um conto tradicional, pois este tipo de texto tende a eleger ações mais "intensas" para provocar certo interesse no leitor e, por fim, surpreendê-lo com uma percepção ou um lance tão impactante que equivaleria, para usar a metáfora de Cortázar, a vencê-lo por "nocaute" (1974, p.153).

As personagens de "Ninguém" (NOLL, 2003a, p.32) também desafiariam as convenções do conto tradicional tendo em vista o fato de que são seres ficcionais indeterminados. A única informação sobre o eu-personagem que articula a narrativa é que este assume o gênero masculino (marcado na palavra "dominado") e que esboça algumas emoções como incerteza e um leve desamparo ou enfado. Não há indicações claras quanto à sua idade, aparência, ocupação, nem quanto às razões que o motivam a negar sua existência quando indagado pelo(a) banhista. O fato de o(a) banhista ser descrito(a) apenas como "um corpo a se banhar atrás da cortina", um corpo desprovido de sexualidade, também dificulta o processo associativo do leitor, que, caso tivesse acesso a maiores informações sobre essa personagem, poderia estabelecer relações, associar dados e intuir a reação que o narrador tem ao vê-la. Esse é um traço comum a vários narradores de Noll, que tendem a evitar a criação 
de um "sonho vívido e contínuo na mente do leitor", desestabilizando o processamento cognitivo de elementos microestruturais do discurso narrativo.

Em Great Dream of Heaven, de Shepard, podemos detectar traço semelhante no conto "Betty's Cats". O texto é formado por um diálogo entre a personagem-título e uma personagem secundária, cujo gênero e relação com Betty permanecem indeterminados (2002a, p.32-42).

Há também um conto chamado "O aceno", na coletânea de Noll, no qual o narrador, de sua janela, avista diariamente um certo banhista que lhe acena todas as manhãs de dentro de uma lagoa. Embora haja uma rotina entre os dois, o narrador contenta-se em vê-lo de longe, apenas como uma "mancha que acena" e afirma preferir não estabelecer contato visual com suas características físicas decifráveis, pois, apenas como mancha, ele "não [1he] provoca ideias, associações" (2003a, p.409).

Essa recorrência de motivos indica, conforme observa Jameson (1991), a preferência da arte pós-moderna, e, por extensão, do conto deste período, pelo consumo de imagens sem maiores aprofundamentos ou relações lógicas, isto é, a imagem "achatada" e desistoricizada (2006, p.32). Os seres e objetos tendem a ser percebidos em sua mera exterioridade, como imagens superficiais, mais ou menos "frouxas", e que provavelmente seriam excluídas ou deixadas para segundo plano em contos tradicionais, por não repercutirem de maneira intensa no ânimo do leitor nem apelarem diretamente para seus processos cognitivos de produção de sentidos.

Na coletânea de Shepard, por exemplo, há um breve conto chamado "Berlin Wall Piece", que, de forma cômica, mostra esse tipo de percepção do mundo apenas em termos de imagens superficiais. $\mathrm{O}(\mathrm{a})$ jovem narrador(a) precisa fazer um trabalho escolar que consiste em entrevistar seu pai sobre o que representaram os anos oitenta em termos socioculturais. Após uma discussão, o pai confessa não recordar nada do que aconteceu durante aquela década: "ele não consegue nem se lembrar de ter vivido durante os anos oitenta". O máximo de informação obtido pelo narrador sobre a "realidade" dos anos oitenta vem de imagens televisivas superficiais e truncadas como videoclipes de Madonna e Michael Jackson e uma propaganda da Chevrolet. Ele também consegue um fragmento do muro de Berlin com sua irmã mais velha, mas esse "pedaço vivo real da história moderna" também é percebido de 
maneira desistoricizada e apenas em termos superficiais: do lado áspero pode-se ver o concreto e do outro há sinais de pichações com tinta spray (2002a, p.19-23). ${ }^{18}$

Quanto ao microconto "Ninguém", a temática da visão merece maior destaque, pois todas as personagens mantêm uma relação problemática com o olhar. A certa altura do texto, por exemplo, somos informados pelo narrador de que outras personagens "ilustres" comparecem à "reunião" indefinida e elas são descritas por meio de sinédoques, que, sem se deter em análises de seus caracteres, só nos informa que elas possuem "pupilas esfuziantes" ou “espumantes", porém não esclarece quem são, qual sua aparência corporal ou motivação para reagir da forma descrita.

Os tipos de incongruências superficiais e recortes de seres e objetos no conto em pauta, bem como em textos de Shepard e de outros autores associados ao pós-modernismo, evocam a técnica lúdica do "cadáver delicado" (cadavre exquis), desenvolvida pelos artistas surrealistas em meados da década de 1920. Trata-se de um jogo no qual, por exemplo, um pedaço de papel passava de mão em mão entre vários participantes e cada um deveria contribuir livremente com uma palavra ou desenho. Como o jogador não tinha acesso à contribuição do participante anterior, o resultado eram sentenças alineares, como a que deu nome ao jogo ("o cadáver delicado beberá do vinho novo”), ou imagens ilógicas, surreais (cf. BRADLEY, 2001, p.24-25). No caso de Noll, a recorrente referência a órgãos (sobretudo as mãos) que adquirem autonomia, rebelando-se contra a dependência e o controle de um todo corporal sugerem a relutância dos seres ficcionais (ou partes destes) e do universo imaginário projetados pelo texto em aterem-se às limitações impostas pela lógica causal e pela coerência. Como nos experimentos lúdicos dos surrealistas, os elementos ficcionais do texto emergem como imagens mentais caracterizadas pela desordem, pela dissociação entre as partes e, em especial, pelo desarranjo das hierarquias das estruturas de representação.

\subsection{3 - Pastiches}

Como mencionamos acima, é um corpo o que falta justamente à personagem mais emblemática do texto "Ninguém": o olhar. As narrações/descrições dos deslocamentos e

\footnotetext{
${ }^{18}$ he can't even remember living through the eighties. [...] a real live piece of modern history.
} 
emoções esboçadas por esse olhar ocupam cerca de dois terços do conto, isto é, detêm o primeiro plano, mas em momento algum o narrador mostra-se surpreso diante de sua suposta disjunção de um corpo. Como sabemos, o olhar depende ao menos de um olho para ser produzido; mas, esse olho, assim como as demais partes de um possível corpo, não se encontra textualizado no âmbito da narrativa ficcional. Ainda assim, esse olhar é capaz tanto de sensações/emoções (entorpecimento, compaixão) quanto de ações (flutuar, submergir, apelar), aspectos relativamente complexos que exigiriam um intelecto e um corpo. No entanto, como o próprio texto enuncia, trata-se de "um olhar sem dono", desprovido de ligações com outros membros, porém autossuficiente.

Aqui talvez estejamos em face de um confronto entre um mundo banal (reunião de pessoas ilustres; banheiro ocupado) e um mundo sobrenatural (um olhar desprovido de olho, de corpo, de mente, mas que ainda assim é capaz de agir e ter emoções) e penetrando no domínio do conto fantástico (TODOROV, 1980; McHALE, 1987, p.73-83). Embora essa não seja nem de longe uma dominante no projeto estético de João Gilberto Noll, o uso de um elemento ilógico como esse "olhar sem dono", pode ser lido como uma tentativa de incorporar à trama narrativa de seu conto pós-moderno aspectos fantásticos intrinsecamente ligados à tradição do conto como gênero e mobilizá-los a fim de reforçar a indeterminação narrativa.

Como os traços do realismo fantástico não costumam fazer parte das narrativas de Noll, o empréstimo desse possível elemento estranho, que foge às regras naturais, remete-nos a uma outra dominante na ficção contemporânea: o pastiche. Jameson argumenta que o pastiche no pós-modernismo consiste no "imitar de um estilo único, peculiar ou idiossincrático" por meio de empréstimos momentâneos de linguagens ou formas do passado. Esse imitar, ao contrário do que ocorre em casos de paródia no estilo clássico, não tem como propósito expor ao ridículo ou enfatizar uma pretensa "anormalidade" desse estilo emprestado, mas apenas de "colocar uma máscara linguística" temporária (2006, p.44-45) ou de promover, conforme classificou Anderson (1998), um "parasitismo em relação ao antigo" (p.60). Embora o realismo fantástico não possa ser considerado um estilo pertencente apenas ao passado, pastiches e outros tipos de empréstimos de topoi e motivos próprios a esse gênero literário, bem como de muitos outros, são traços dominantes em diversos romances, contos e outras manifestações literárias pós-modernas (McHALE; 1987, p.73-83). 
Shepard, por exemplo, toma emprestadas, sem intuito satírico, situações presentes no film noir e no filme de terror e combina-as com referências e elementos próprios aos subgêneros televisivos, como a propaganda, a soap opera e o programa de auditório, na composição do conto “The Company's Interest”, da coletânea Great Dream of Heaven. Esses pastiches e colagens conferem uma textura tragicômica ao relato em primeira pessoa de uma funcionária de posto de gasolina que, forçada a trabalhar no turno da noite em um local remoto, é constantemente atormentada pelas ameaças do chefe e por sua imaginação, que insiste em pregar-lhe peças baseadas em julgamentos superficiais da aparência dos clientes (cf. SOBREIRA, 2008).

Além disso, os contos de Shepard com frequência também tomam emprestados motivos do estilo gótico como, por exemplo, no conto "Blinking Eye", de Great Dream of Heaven, em que a protagonista faz uma longa viagem transportando as cinzas da mãe falecida em uma urna funerária. Contudo, um acidente de carro acaba espalhando o conteúdo do recipiente sobre o rosto da personagem que prova do sabor dos restos mortais: "Sua mãe tem gosto de sal" (2002a, p.30). ${ }^{19}$ Imagens insólitas de familiares, em especial os pais, em chamas ou reduzidos a cinzas são recorrentes na arte de Shepard desde a peça $A$ Lie of the Mind (1986, p.32), os roteiros dos filmes Silent Tongue (EUA, Reino Unido, França, 1992) e Don't Come Knocking (Estrela solitária, EUA, 2005), além de outros contos como "Cruising Paradise", em que o filho recolhe os restos do colchão no qual seu pai morreu bêbado e carbonizado (1996a, p.40-41). O teórico Adler (2002) chama atenção para elementos macabros e os associa ao estilo neogótico (p.121), em Shepard, como a presença de um bebê exumado e a carcaça de um cordeiro, respectivamente, nas peças Buried Child e Curse of the Starving Class. Empréstimos do maravilhoso também podem ser detectados no conto "Sea Sleep", da coletânea Hawk Moon (SHEPARD, 1981, p.78).

Como observamos na seção anterior, manifestações paradigmáticas do conto, por mais que confiassem nos poderosos processos associativos da mente humana e nas capacidades cognitivas de reconhecer um objeto mesmo a partir de índices e traços mínimos, provavelmente relutariam em eleger como foco narrativo um narrador-protagonista, ou seja, um eu, como o que fala em "Ninguém" e cujos traços distintivos são, de maneira deliberada, descaracterizados. Da mesma forma, um contista mais afeito às prescrições de Smith (1902) ou mesmo Hills (2000, p.6), para quem o autor tem a "responsabilidade" de deixar claro para

\footnotetext{
${ }^{19}$ Her mother tastes like salt.
} 
o leitor as circunstâncias que motivam os comportamentos das personagens, hesitaria em trazer para primeiro plano um olhar descorporificado, cujos movimentos e "apelos vagos" podem ter alguma relação, porém, pouco explicitada, com as ações posteriores do narrador. Isso mostra uma tendência do conto contemporâneo em levar a extremos ainda mais drásticos as omissões praticadas por autores como Hemingway e Carver. Essas narrativas omissas no tocante à causalidade constituem-se como conjuntos de eventos fragmentários que não coincidem com os esquemas clássicos de ações constantes dos scripts armazenados na memória do leitor, aos quais este recorre durante os processos cognitivos envolvidos na compreensão do texto. O capítulo seguinte será dedicado ao refinamento dessas ideias.

\subsection{4 - Quebra do continuum espaçotemporal}

Além de o texto "Ninguém" não deixar claro quem está narrando a história, quem ou o que exatamente são as personagens e o que está acontecendo, as referências espaçotemporais são mínimas. Há outras obras contemporâneas conhecidas por não fazerem referências claras a onde e quando se passa a história. Podemos citar a peça Esperando Godot (1952), de Samuel Beckett, e o romance Ensaio sobre a cegueira (1995), de José Saramago. Embora estas duas obras sejam escritas em gêneros muito mais "substanciais" do que o conto de Noll, interessa-nos comparar apenas os traços indeterminados comuns aos universos ficcionais dos três objetos artísticos. Dessa maneira, podemos afirmar que, no texto de Noll, a construção do território imaginário ocorre em termos muito mais obscuros. Em Esperando Godot, ainda que a escrita despojada de Beckett tenha reduzido as referências espaçotemporais a "Uma estrada rural. Uma árvore. Noite" (1982, p.1), ${ }^{20}$ sem maiores indicações quanto à época ou o país em que a história ocorre, o leitor ainda é capaz de "traduzir" essas informações em termos conceituais: pode-se "visualizar" mentalmente Estragon e Vladimir sentados à beira da estrada, sob uma árvore ressecada. A passagem do tempo é vagamente indicada pelo surgimento de algumas folhas na árvore. No caso de Saramago, embora a narrativa não mencione o país ou o tempo em que se dá a história, o leitor consegue depreender que se trata de um asilo em uma grande metrópole em tempos atuais. Ambos os livros são marcados pela noção de lieu vague, isto é, esses detalhes factuais

\footnotetext{
${ }^{20}$ A country road. A tree. Evening.
} 
são deixados para segundo plano, pois Beckett e Saramago estão mais interessados em dotar as experiências representadas de um caráter aberto ou universal.

O mesmo não ocorre, no entanto, com "Ninguém", de Noll, pois a indeterminação do relato mínimo desestabiliza violentamente esses referenciais: não há como sabermos com o mesmo grau de certeza que temos ao ler Beckett e Saramago se se trata de uma casa, uma galeria, uma repartição, uma loja etc., pois as únicas "pistas" são uns quadros, um lustre e alguns móveis com poeira, ou seja, traços aplicáveis a inúmeros locais. A palavra "móveis", por exemplo, é muito genérica e não ajuda o leitor a racionalizar esse espaço de maneira totalizante. Além disso, o texto não menciona se estamos diante de um lugar espaçoso, apertado, barulhento ou desorganizado, traços que poderiam levar o leitor a formar um conceito um pouco mais nítido do local.

O mesmo ocorre com "Betty's Cats", de Shepard: embora as duas personagens se refiram ao trailer onde Betty vive com seus gatos, a conversa projetada pelo conto dá-se em um momento indeterminado e em outro local indefinido. Em outras palavras, a ideia de lieu vague parece não dar conta da extrema "incompletude" do espaço projetado por essas narrativas. Nesse caso, não estamos diante de referenciais espaçotemporais meramente deslocados para segundo plano, mas de informações essenciais que foram suprimidas de maneira deliberada pelo narrador.

As referências temporais são muito frágeis também no conto de Noll: a narrativa dá conta apenas de que "uma faixa de sol alumiava", levando o leitor a inferir que a primeira parte dos acontecimentos desenrola-se durante o dia. No entanto, o conto não deixa claro qual o intervalo de tempo decorrido entre a troca de olhares e os acontecimentos no banheiro. Teriam ocorrido no mesmo dia e local? Além de ser uma história que poderia acontecer em qualquer época ou lugar, pois não há traços marcantes de nenhuma cultura ou período específicos, a narrativa ao mesmo tempo parece não ocorrer em lugar ou tempo algum, pois o caráter esquemático dos dados cria "pontos cegos" que resistem ao processamento cognitivo do leitor. A narrativa inteira surge como uma colagem de ações e personagens fragmentárias em um tempo-espaço desistoricizado, como se os quadros e o lustre estivessem pendurados em uma parede invisível, os móveis instalados sobre um espaço sem perspectiva e as personagens fossem aludidas apenas por dados extremamente parciais.

Se, por um momento, pensarmos a respeito dos contos "Ninguém" e "Betty's Cats" em termos de informação factual e não como textos ficcionais artísticos, diríamos que esses 
textos violam uma das regras mais básicas na compreensão da informação: a do lead narrativo. Teorias do jornalismo definem o lead (ou lide) como um conjunto de informações indispensáveis ao relato e que respondem às perguntas básicas do leitor: o quê, quem, como, onde, quando e por quê (PENA, 2005, p.41-49). Sua origem remete aos antigos relatos orais e tem a finalidade pragmática de tornar mais eficiente a comunicação de uma informação, situando os fatos em um espaço-tempo coerente, daí sua importância para a notícia (LAGE, 2005, p.73-74).

Como sabemos, a natureza fictícia do texto literário desobriga-o da necessidade de articular essas informações de maneira direta e inequívoca. No entanto, a narrativa, sobretudo a de orientação realista, tende a incorporar alguns desses "realemas" (cf. McHale, 1987, p.86), como se fossem "respostas" a cada uma das perguntas do lead narrativo, com a finalidade de criar a ilusão de que a história realmente aconteceu. Embora algumas obras não forneçam respostas totalizantes a muitas dessas questões narrativas, um modelo familiar de narrativa em prosa responde de modo satisfatório, ao menos em algum momento da narração, a essas perguntas. O fato de o conto de Noll em particular não atender às questões do lead narrativo não se deve necessariamente à brevidade do texto. Como vimos, o conto "The Scarlatti Tilt" é ainda mais breve e, no entanto, responde a todas as questões: o quê? A confissão de um crime (provavelmente um homicídio). Quem? Uma mulher e um homem (estudante de violino). Como? Com disparos de arma de fogo. Onde? Em uma quitinete em San Jose, Califórnia. Quando? Quando a suspeita entregou o revólver à polícia. Por quê? Provavelmente porque ele a enlouquecia com o som desafinado e repetitivo do violino.

Embora outras possibilidades de leitura em nível macroestrutural sejam possíveis, pode-se afirmar que se trata de uma representação "completa" de um episódio. Em virtude de a história ser construída de modo bastante palpável, o leitor, por conseguinte, compartilha dos dados aludidos e pode proceder à restauração de um determinado padrão de enredo. Isso mostra que traços indeterminados não se devem a restrições de caráter físico do texto, mas podem ser incorporadas à trama ficcional de maneira deliberada.

Há inclusive textos mais longos que também operam com dados parciais de seres e supressão de coordenadas espaçotemporais: consideremos, por exemplo, o recente conto "Plainface", de Jesse Ball (2009). Nesse texto de trinta páginas, a personagem-título não é apresentada pelo narrador como um todo, isto é, durante grande parte da narrativa não sabemos qual sua idade ou aparência. Quando o narrador, transcorridos mais de um quarto da 
narrativa, finalmente começa a descrever os aspectos físicos da personagem ao leitor, os detalhes escolhidos não são os esperados como idade, cor dos olhos, tipo de cabelo, mas detalhes insólitos como: "seus joelhos eram mais grossos do que a coxa logo acima ou a panturrilha, embaixo. Sob sua camisa imunda, via-se a saliência de cada costela. Não se podia dizer que seu cabelo fosse de determinada cor em particular. Sua mão esquerda era incrivelmente rápida, sua mão direita bastante lenta" (p.108). ${ }^{21}$ Além de a menção desses traços não responder às dúvidas básicas do leitor — afinal, trata-se de um adolescente ou de um adulto? - as partes descritas não são de aparente relevância para a história narrada. O fato de Plainface ter joelhos grossos e cabelo de cor indefinida não "esclarece" nenhum dos fatos posteriores ou anteriores da narrativa. Do ponto de vista meramente utilitário, eles não têm "serventia" prática para o leitor. Além das ambiguidades que cercam o universo ficcional de "Plainface", pode-se dizer que o leitor não toma consciência da personagem como um todo, isto é, como um corpo formado, completo. As descrições esparsas dos traços físicos da personagem ao longo dos blocos de texto que compõem a narrativa, bem como suas constantes mudanças de identidade e a "falta" de controle do narrador sobre seu próprio relato, bem como a "falha" em responder às questões do lead narrativo, colaboram para reforçar o aspecto fragmentário e indeterminado do texto ficcional.

Dessa forma, o leitor, ao confrontar-se com um texto convencional que, ao longo da narração, articula "respostas" às questões do lead narrativo, torna-se capaz de processar essas informações, por mais estranhas que sejam, e "reconstruir" em sua mente um padrão consistente de acontecimentos e então organizá-los de modo a formar um conceito, um padrão de desenvolvimento de ações e personagens, isto é, um enredo. Até mesmo histórias fantásticas, romances de ficção científica, contos alegóricos, entre outros, em geral respondem à maioria dessas questões básicas da narrativa. O conto "Ninguém", no entanto, ao valer-se de omissões drásticas de referências espaçotemporais e da adoção de uma ordem indeterminada de ações, dificulta o processamento cognitivo dessas categorias narrativas, isto é, a concatenação mental das partes do enredo. O universo ficcional projetado por esse texto é instável e descontínuo, composto por uma colagem de fragmentos desiguais, que não satisfaz às expectativas do leitor e provoca a desestabilização da percepção. O leitor de "Ninguém" não tem a seu dispor respostas consistentes às questões básicas da narrativa, e, dessa forma, não há como determinar com alguma precisão o que está acontecendo nessa história. Por essa

\footnotetext{
${ }^{21}$ His knees were thicker that the thigh above or the calf below. Under his dirty shirt, every rib stuck out. His hair could not be said to be of any particular color. His left hand was incredibly fast, his right rather slow.
} 
razão, cabe-lhe tentar processar esses elementos fragmentários de modo a obter um modelo de enredo provisório, tentando completar as lacunas, mediante o preenchimento das categorias problemáticas, ou "porosidades", do universo ficcional.

\subsubsection{Tentativas de processamento cognitivo do enredo}

Algumas dessas possibilidades de preenchimento incluem, por exemplo, a hipótese de que o narrador-protagonista de "Ninguém" participa de uma reunião com pessoas "ilustres", provavelmente mais velhas (pupilas "espumantes" podem remeter à brancura da catarata), que conversam animadamente (daí as pupilas “esfuziantes”) sobre algum (ou vários) assunto(s). Como o conto menciona quadros, o lustre, uma faixa de sol, alguns desses assuntos poderiam ser arte, antiguidades, o calor, entre outros. A reunião poderia se passar em uma mansão ou casa antiga, com móveis e quadros cobertos por uma fina camada de poeira. O narrador, por alguma razão, sente-se deslocado, pois os assuntos são muito triviais ou muito especializados. Sentindo-se excluído, passa a observar os objetos da sala e, então, ele nota uma outra pessoa que, embora esteja presente na reunião, sente-se tão isolado quanto ele. Os dois olhares se cruzam e ocorre uma identificação mútua entre eles. O narrador sentese absolutamente atraído pelo olhar do outro e, pensando neste como um outro homem, podese imaginar um desejo homoerótico entre eles. Essa possível atração, no entanto, não ousa dizer seu nome, ou seja, não é verbalizada no corpo do texto, permanecendo no campo das sugestões, como ocorre no conto "I Want To Know Why" (1921), de Sherwood Anderson, em que dois tratadores de cavalos de corrida trocam um olhar carregado de erotismo (ELLIS, 1993, p.599-600). Quanto a "Ninguém", o fascínio que o olhar lânguido, entorpecido exerce sobre o narrador é tão intenso que este dedica cerca de dois terços de seu relato a esse olhar vago, ora terno, ora ambíguo (compaixão de "tudo e nada"). A troca de olhares entre os dois é "invisível” aos demais, que continuam conversando com aparente entusiasmo.

As implicações imagéticas dos termos "inseminação atávica" podem sugerir uma atração de ordem sexual entre os dois. Além disso, o "apelo vago" contido no olhar do outro homem, tão intenso que "domina" o narrador, pode ser um convite ao flerte, ao sexo, à ancestral troca de fluidos (no caso, o sêmen). Conforme veremos, a temática homoafetiva é um traço bastante marcante na ficção de João Gilberto Noll, explorada em romances como 
Berkeley em Bellagio (2002) e, sobretudo, em Acenos e afagos (2008), em que o narradorprotagonista narra um encontro de sexo casual com um parceiro desconhecido em um banheiro público (2008, p.42). No caso de "Ninguém", o lugar escolhido para a consumação desse hipotético ato sexual também seria o banheiro, para o qual o narrador se dirige, meio incerto. E embora afirme que o faz com a finalidade de lavar as mãos, essa justificativa soa mais como um pretexto, uma estratégia para conter a ansiedade, afinal, ele diz que é acometido por uma espécie de "surto de exclusão", isto é, uma premência de encontrar um local apartado ("excluído") para consumar o ato sexual, que o deixa "aceso" de excitação. Pode-se inferir que o narrador, atendendo ao "apelo" do olhar e ao seu próprio desejo, tenha se dirigido ao banheiro antes do outro homem em observância tanto à necessidade de discrição quanto à dinâmica de funcionamento desse tipo de encontro casual. No entanto, ao ser surpreendido pelo fato de estar um “corpo a se banhar", e devido à sua própria frustração diante dessa complicação, o narrador se retira pela porta de serviço, em sinal de desistência do encontro hipotético.

Em uma outra possibilidade de processamento cognitivo das personagens e ações narradas, poderíamos pensar que a "história" se passa em uma casa comum, decorada com alguns móveis empoeirados onde pessoas ilustres, talvez políticos locais, conversam animadamente. Dadas as implicações imagéticas da proposição "um olhar sem dono", podemos associá-la a um ser sem dono, como um cão desamparado. Escondido sob um dos móveis, esse cão hipotético observa com seu "olhar sem dono" a reunião de "pupilas espumantes", ora observa os objetos, enquanto seu olhar segue "flutuando entre os móveis e o lustre", numa provável sensação de letargia. Muito embora não haja um cão inscrito textualmente na narrativa, o olhar benevolente desse possível animal é "invisível" a todos os presentes, exceto ao mais entediado deles, o narrador, uma pessoa triste e ensimesmada, que lhe acompanha cada movimento. Ao notar que tem a atenção do narrador, o cão dirige-lhe um olhar de súplica, um "apelo vago" (por comida?). O narrador é então envolvido (ou "dominado") por esse "olhar sem dono" e vivencia uma epifania, isto é, experimenta um súbito desvendamento de um aspecto da realidade que até então estivera obscuro, passando a perceber-se como um estranho ao grupo, como um excluído. Os móveis, os quadros, o lustre empoeirado e, sobretudo o cão sem dono, funcionariam como "objetivo correlativo", para adotar a terminologia de T.S. Eliot (1975, p.48), desse sentimento. Em outras palavras, eles formariam um conjunto de objetos, em uma determinada situação, imbuídos de uma rica experiência sensorial, que imediatamente evocaria uma emoção: no caso, uma dolorosa 
sensação de desamparo e exclusão. Na tentativa de livrar-se desse sentimento hipotético, o narrador se refugia no banheiro com o intuito de lavar as mãos "como que para selar o surto de exclusão", mas seu intento é impedido pela pessoa que ocupa o banheiro. E ao ser indagado, o narrador, ironicamente murmura que é um ninguém, tornando-se enfim tão insignificante e "invisível" quanto o cão sem dono. Dessa forma, quando o narrador deixa a reunião de ilustres e sai pela porta de serviço, teríamos o recorrente motivo da anomia social, comum a vários sujeitos que povoam os textos de Noll.

Há ainda outras possibilidades de processamento cognitivo dos dados fragmentários projetados pelo conto "Ninguém", 22 porém, nenhum desses modelos de enredo parece coincidir com os elementos superficiais narrados pelo texto. A todas essas possibilidades de esquematização parece sobrar ou faltar alguma coisa, pois, em virtude das muitas generalizações e "violências" que fomos forçados a cometer em nome de uma tentativa de completar as indicações parciais e totalizar esses elementos díspares, nenhuma das hipóteses se "encaixa" de maneira satisfatória. Além disso, ao voltarmos ao texto depois de várias leituras, é provável que alguns desses possíveis enredos hipotéticos comecem a se sobrepor e a se autossabotar. Essa irredutibilidade a um padrão de enredo linear tende a ser associada à poesia lírica e à pintura vanguardista, traço que mostra uma interface do conto de Noll tanto com a prosa poética (MARCHEZAN, 2006, p.235) quanto com as artes plásticas, sobretudo a de Jasper Johns (Fig.1), por exemplo. ${ }^{23}$

Não entramos aqui ainda no domínio das interpretações macroestruturais do texto literário, que, por definição, não é fixado de maneira objetiva e, de modo geral, pode sofrer muitas variações dependendo do contexto (EAGLETON, 1996, p.61). Estamos tratando apenas de um reconhecimento inicial das microestruturas do enredo, isto é, da capacidade de resumir em poucas palavras uma sucessão de lances narrativos superficiais envolvendo personagens. No caso de "Ninguém", o processamento cognitivo desse esquema básico tornase um desafio maior do que em textos cujo enredo é mais familiar.

\footnotetext{
${ }^{22}$ Raffa (2007), por exemplo, oferece um modelo de enredo completamente diferente para esse mesmo texto (p.176-179).

${ }^{23}$ Quanto a Johns, temos em mente, sobretudo, uma das gravuras (Fig.1) em que se pode ver um painel abstrato, marcado por linhas em vários sentidos que se entrecruzam ocasionalmente. Em certas junções dessas linhas há algumas "manchas" claras sem forma definida em que aparecem escritos em grafia cursiva nomes de partes do corpo como knee, buttocks, face, leg, torso, hand e outros traços mínimos como sock e floor. Esses componentes, assim como as personagens do conto de Noll, aparecem completamente dissociados no espaço bidimensional da tela e os formatos variados das "manchas" esbranquiçadas ora podem ser associados à silhueta do componente designado, mas, na maior parte das vezes, não é possível identificar nenhuma semelhança, e recompor os fragmentos desse(s) corpo(s) (cf. GEELHAAR, 1980).
} 


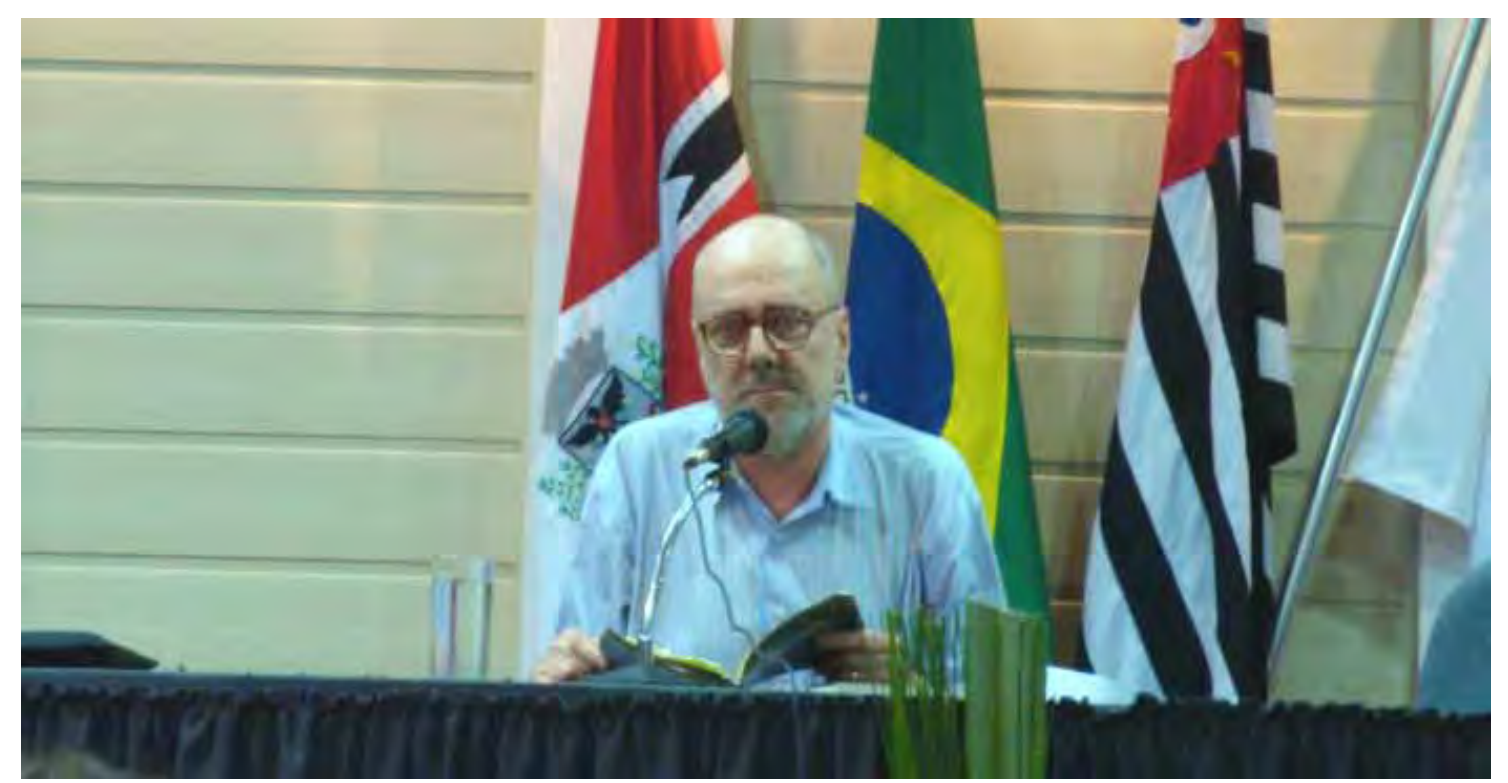

João Gilberto Noll

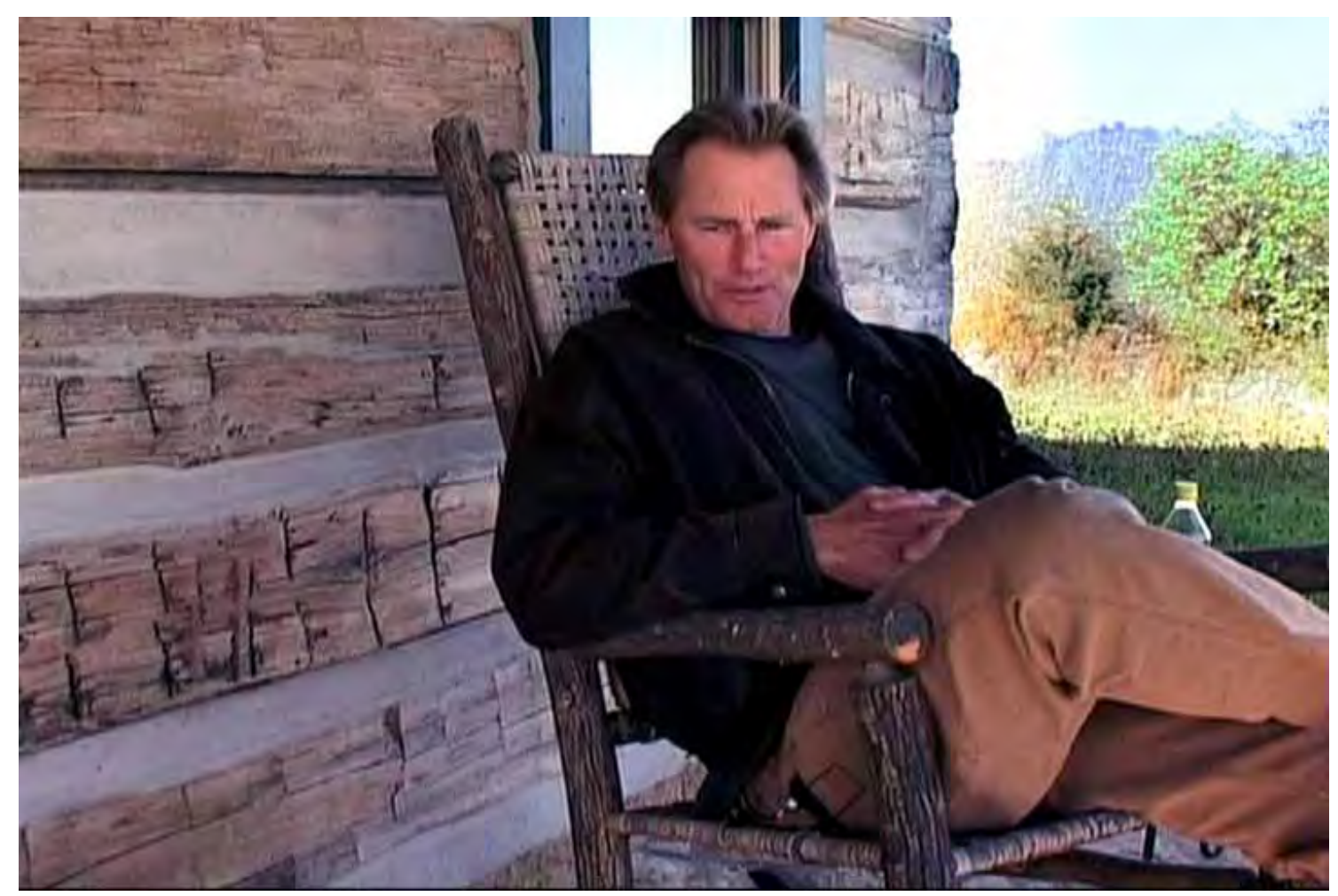

Sam Shepard 


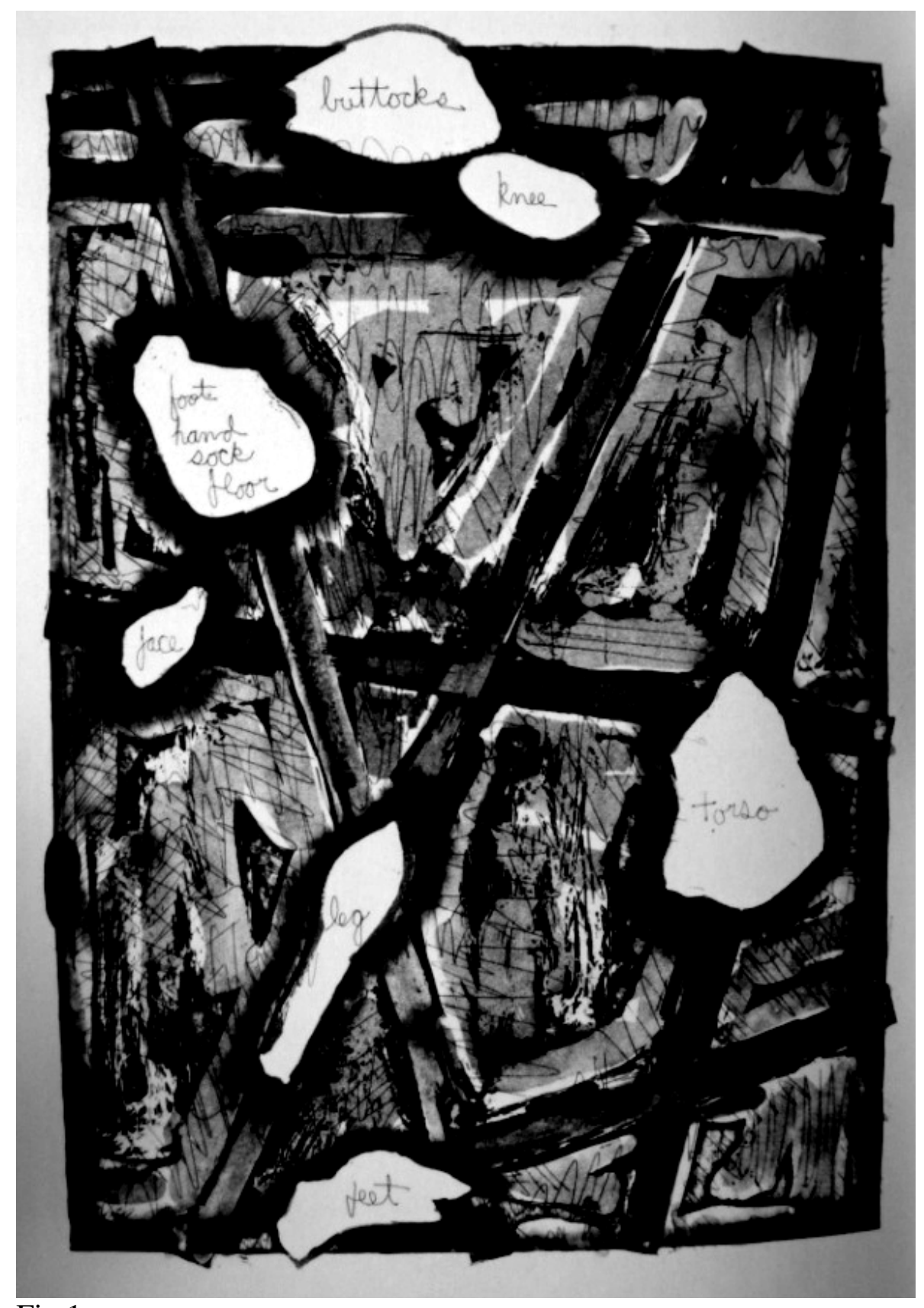

Fig.1 


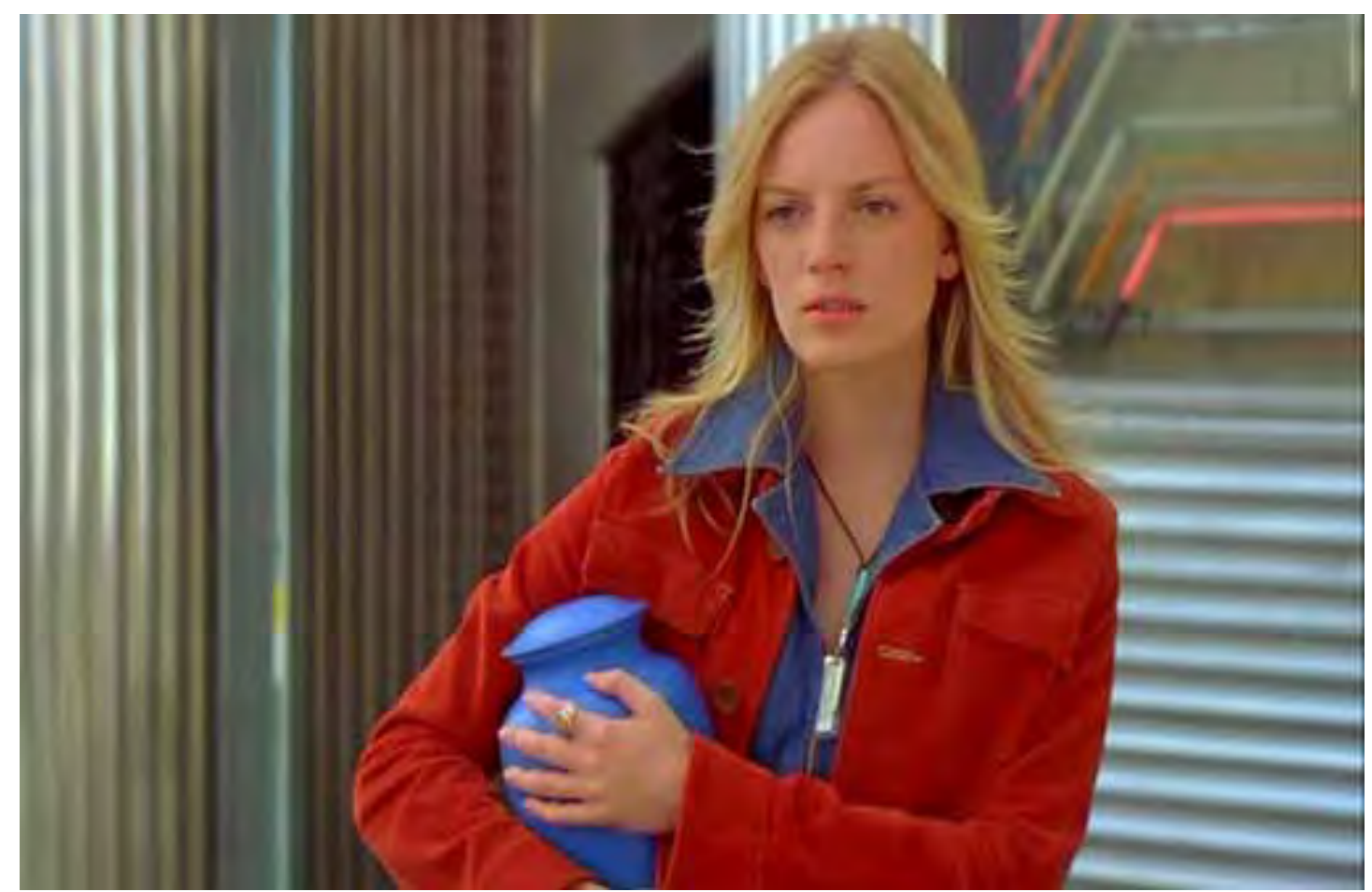

Fig.2

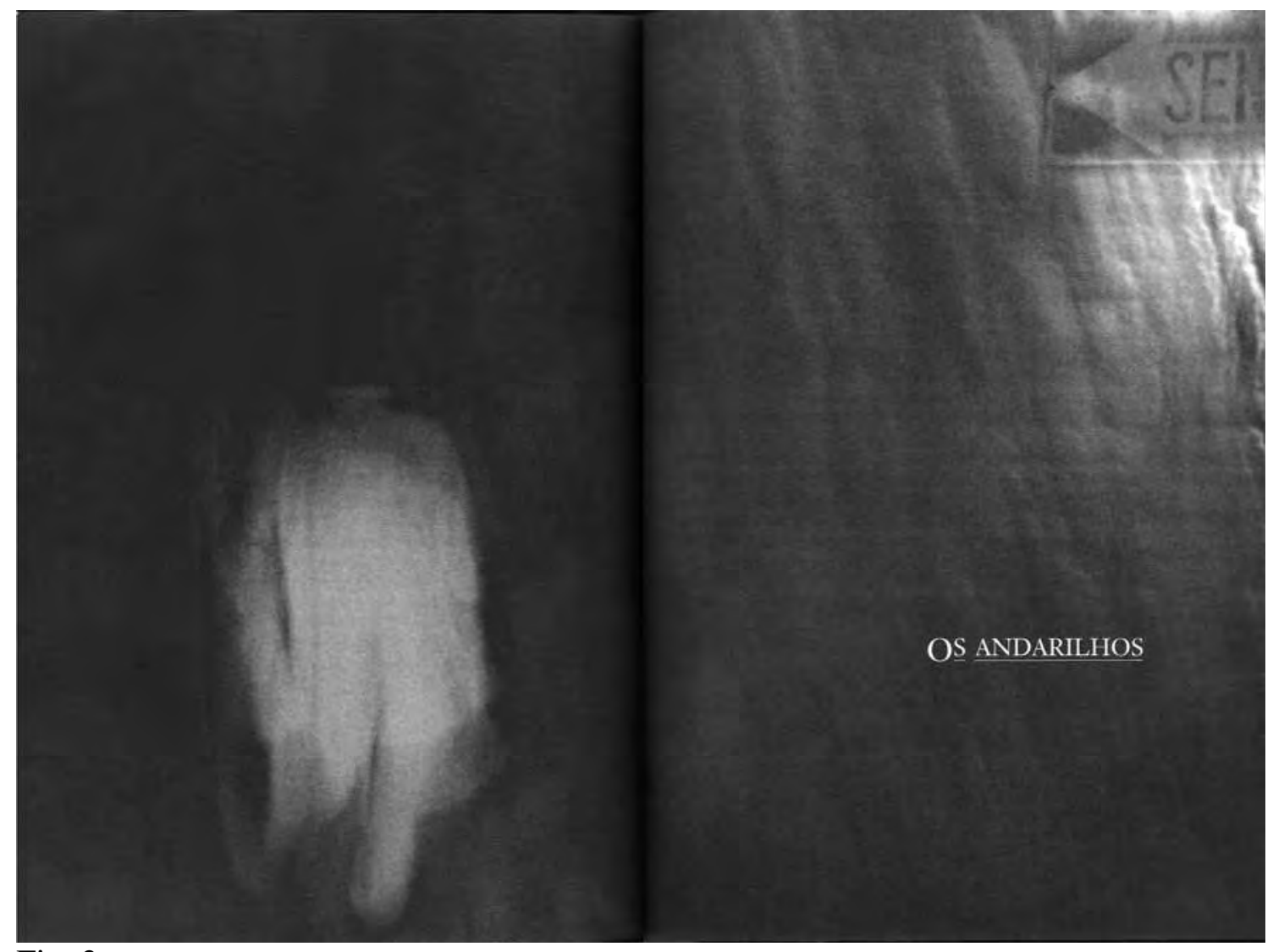

Fig. 3 


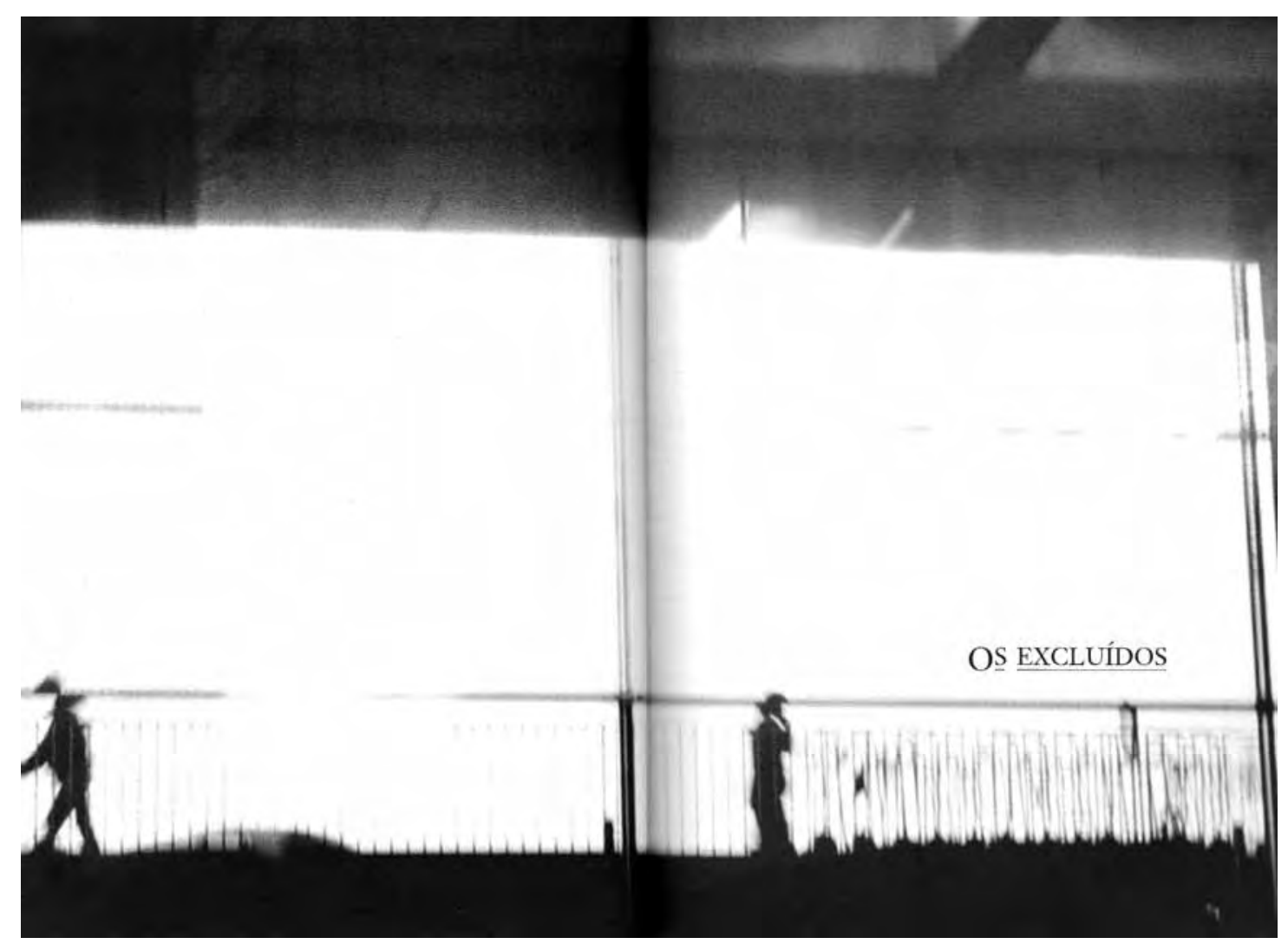

Fig.4

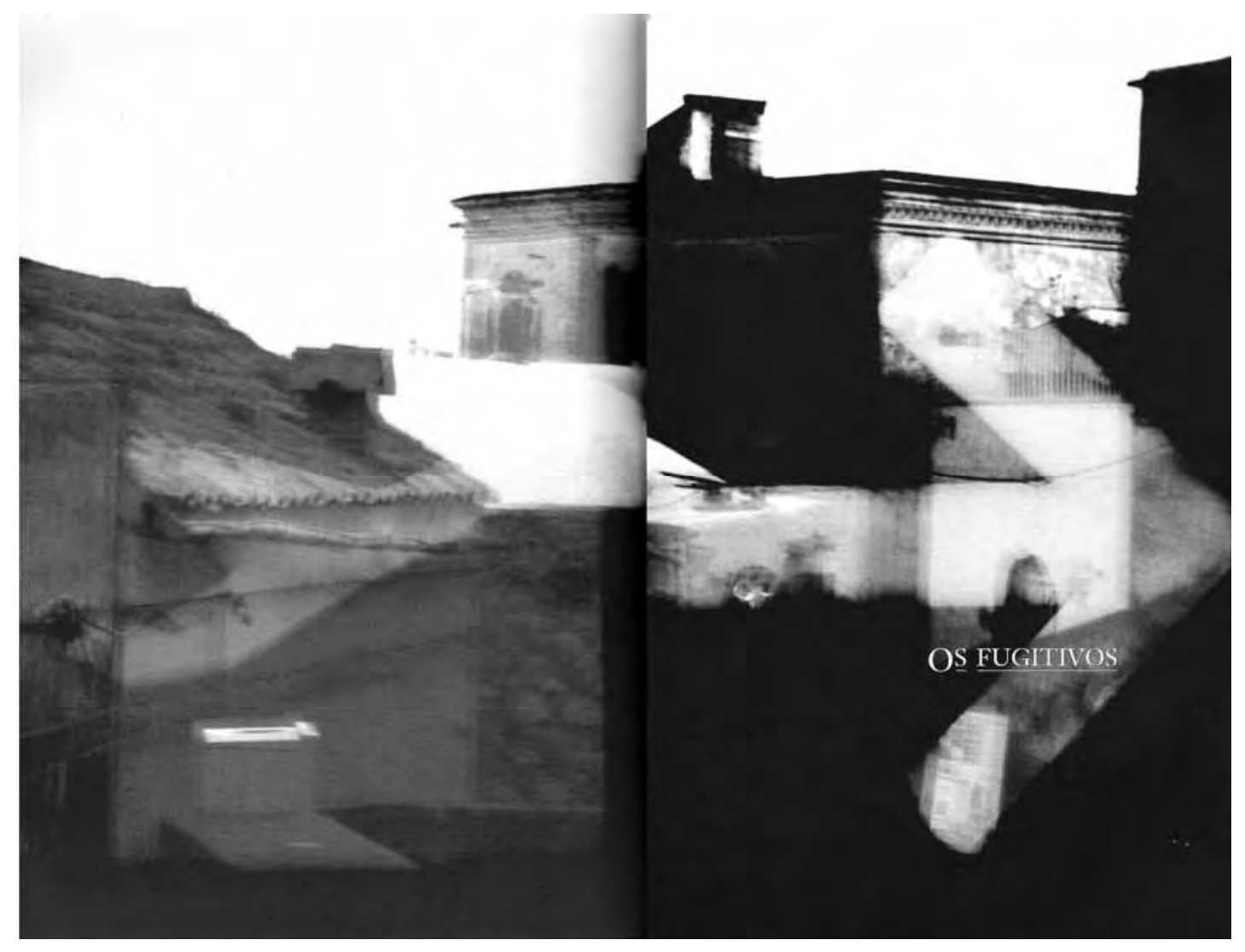

Fig.5 
Talvez essa dificuldade se deva ao fato de que, ao tentarmos "traduzir" as sequências de proposições do texto em termos de um modelo de enredo, tentamos restaurar um padrão classificado por Van Dijk como "ordem esquemática canônica” (1979, p.157), mas que não está facilmente disponível no texto de Noll e, em virtude da colagem de imagens e partes descaracterizadas, não sabemos ao certo sobre o que ou quem é a história. Por essa razão, a concepção do que seja o enredo de um texto como "Ninguém" tende a variar muito a depender do leitor, pois o fato de o conto não aderir a um plano mais ou menos reconhecível de ações e relações causais tende a interferir no processamento cognitivo do discurso literário.

Steven Connor (2004) reconhece nessas "interferências" propostas pelos contos contemporâneos um traço distintivo do pós-modernismo. Segundo o autor, ao contrário da narrativa breve moderna - que, mesmo calcada em omissões, ainda privilegia a completude conceitual - os contos pós-modernos são caracterizados pela excentricidade, pela incompletude e por um "interesse nos padrões de interferência" no processo de totalização, por meio de um conjunto complexo de ficções fraturadas (p.74-75).

O livro Mínimos, múltiplos, comuns, de Noll, é de fato um conjunto complexo de instantes ficcionais. A maioria dos textos reunidos no volume, como vimos, foi originalmente publicada em uma ordem diferente em outra mídia, em uma coluna semanal denominada "Relâmpagos" (MARCHEZAN, 2006, p.231, n.1). Ao serem agrupados em formato de livro, Carelli, o editor da coletânea, tentou conferir ao volume uma "lógica essencial" que pressupõe uma "cronologia da Criação" (NOLL, 2003a, p.23). No entanto, a escrita fragmentária, indeterminada e elíptica dos contos, algumas vezes identificados com o minimalismo literário (CARELLI, 2003, p.19), tende a interferir nessa aparente tentativa de organizar de modo totalizante o universo ficcional. Em outras palavras, ainda que o editor tente organizar esses "relâmpagos" discursivos em conjuntos e subconjuntos de acordo com um plano coerente, esse esforço não os torna um corpo textual uniforme. A disposição desses contos segundo uma cronologia linear de base criacionista não diminui a complexidade individual de cada um desses textos, nem muda o fato de se tratar de uma colagem de instantes ficcionais fragmentários, inicialmente destinados a figurar em um veículo de rápida obsolescência como o jornal.

Além disso, ao contrário de coletâneas de contos como Dubliners e Winesburg, Ohio, ou em ciclos de histórias mais antigos como The Canterbury Tales (1385-1400), de Chaucer, 
e o Decameron (1349-51), de Boccaccio, em que os autores se propõem a examinar por ângulos diversos as personagens que coabitam um determinado espaço-tempo, visando criar cumulativamente uma impressão específica sobre esse grupo, em Mínimos, múltiplos, comuns e Great Dream of Heaven, por outro lado, não há essa construção de uma "comunidade" em sentido tradicional. A coletânea de Noll, em especial, embora se proponha - a partir da estruturação de Carelli - a desenvolver um "projeto de mundo", conserva a aparência de ficções relativamente desconectadas e não a de um sistema coerente e organizado em torno de pessoas coabitando um espaço comum, que prefigure um conceito totalizante de "povo" ou "humanidade". O volume repercute mais como um embaralhamento de universos, com coordenadas espaçotemporais divergentes ou quase nulas. E assim como em Great Dream of Heaven, de Shepard, a coletânea de Noll focaliza personagens fragmentárias que, em suas existências atomizadas, falham ou nem tentam comunicar-se, em um sentido mais amplo, e estabelecer laços minimamente consistentes com outros indivíduos.

Como veremos, em Great Dream of Heaven, Shepard também se interessa por engendrar em sua escrita padrões de interferência, sobretudo no tocante a concepções cristalizadas que concebem a subjetividade humana como identidade monolítica. Contos como "Tinnitus", "Betty's Cats", entre outros, questionam a "integridade" tanto dos seres ficcionais quanto do universo projetado pelo texto mediante um fluxo de narrativas descontínuas e minimalistas, que apontam para as discussões em torno da chamada crise da linguagem, à qual voltaremos no próximo capítulo.

Feitas essas observações a respeito das características atípicas, em termos de processamento cognitivo das microestruturas narrativas, dos textos de João Gilberto Noll e Sam Shepard, passemos, a seguir, a uma breve discussão sobre a influência de procedimentos ficcionais minimalistas na construção de alguns desses contos pós-modernos.

\subsection{Considerações sobre o minimalismo literário}

Uma das definições mais aceitas de minimalismo encontra-se no ensaio "A Few Words About Minimalism" (1986), de John Barth, em que o autor distingue duas possibilidades de articulação do conceito. A primeira delas diz respeito ao estilo minimalista, que inclui o uso de "um vocabulário despojado, uma retórica despojada e um tom não 
emotivo". ${ }^{24}$ A segunda possibilidade refere-se ao âmbito material e consiste em uma redução de personagens, exposição, mise-en-scène, ação e enredo a níveis mínimos (1995, p.68). O crítico inglês Daniel Just (2008), no entanto, não concorda com essa definição, pois ela se aplicaria a uma gama excessiva de autores e não a escritores como Raymond Carver, Bobbie Ann Mason, Ann Beattie, Amy Hempel, Donald Barthelme, entre outros, que são com mais frequência associados à emergência do conto durante os anos oitenta e tendem a ser agrupados sob o rótulo estigmatizado do minimalismo literário (p.310).

Hallett (1999), por exemplo, reconhece em Tchekov, Hemingway e Beckett um certo minimalismo em estágio embrionário, mas circunscreve o termo a contistas contemporâneos, sobretudo os citados acima, e define a tendência minimalista como um conjunto de estratégias ficcionais próprias ao conto literário como, por exemplo, a construção de narrativas utilizando meios mínimos para atingir fins muito mais amplos em termos de significação (p.3). Devido à extrema brevidade, essas histórias realizam uma "prudente redução de equações complexas [...] até que o complicado é expresso nos termos mais simples" (p.7). Segundo a teórica, o acesso ao universo ficcional é feito por meio de uma perspectiva tão oblíqua quanto um "buraco de fechadura" (p.17), em geral, filtrada por um narrador que evita fazer intervenções editoriais na história e que recusa a "fabulação", optando por um tom apático e informal, marcado por uma prosa seca, sem "enfeites" linguísticos. A seguinte passagem do conto "Celia Is Back" (1985), de Hempel, ilustra alguns desses aspectos, bem como a condensação, banalidade, prosaísmo linguístico e impassibilidade da voz narrativa, comuns à prosa minimalista:

O pai fechou os olhos, recostou-se na poltrona, e disse:

- Gosto de pudim Jell-O porque gosto de uma refeição energética depois de uma rápida caminhada em um dia de inverno - Algo que realmente me aqueça.

O menino deu uma risadinha e a menina também (p.19). ${ }^{25}$

Calabrese (1999), em discussão do minimalismo americano, argumenta que o fato de nada ou quase nada ocorrer nesses contos deve-se à tentativa, por parte dos autores

\footnotetext{
24 a stripped-down vocabulary, a stripped-down rhetoric, and non-emotive tone. Outras referências ao minimalismo incluem Anderson (1998, p.96-102) e Zoltán (2001).

${ }^{25}$ The father closed his eyes, and leaned back in his chair, he said, "I like Jell-O-pudding because I like a good hearty meal after a brisk walk on a winter's day - something to really warm me up.”

The boy giggled and the girl giggled.
} 
"minimalistas", de procederem "precisamente à anulação do texto narrativo" (p.185). ${ }^{26}$ Segundo o autor, esse procedimento evita a experimentação e pode ser interpretado como sintomático da recente emergência de uma "estética do Nada" (Id., ibid., p.185), isto é, uma tentativa de reduzir a palavra ao seu sentido mais literal, contendo os "floreios" estilísticos e a reverberação poética dos signos.

Os textos são com frequência regidos pelo chamado "realismo sujo" (p.10), ${ }^{27}$ bem como pela representação de personagens acometidas por uma espécie de paralisia emocional, marcada por uma ausência do desejo de participar ativamente do convívio social. Federman (1985) associa a retração na economia americana durante a era Reagan como responsável pela emergência de narrativas minimalistas (p.75). As narrativas, de certa forma, projetam uma imagem do mundo de maneira geral como um lugar cheio de limitações, alheio ao controle do ser humano, e denotam a futilidade do agir e a inabilidade da linguagem em comunicar com precisão (Hallett, 1999, p.10).

As definições de Hallett, no entanto, mostram uma extrema preocupação da autora em tentar incluir os textos e autores minimalistas no domínio da "alta" cultura. Dessa forma, sua visão de minimalismo está muito mais vinculada ao modernismo americano e a um modelo mais "satisfatório" de narrativa, capaz de fazer o leitor encontrar "o todo da sociedade refletido em pedaços de experiências individuais" (p.7, grifo nosso). Em outras palavras, seria como se o conto minimalista fosse uma espécie de mensagem em um biscoito da sorte cujo sentido fosse mais amplo. As análises da autora, via de regra, tentam de certa forma redimir a "incompletude" das histórias por meio de uma tentativa de recompensar o leitor com um ideal de significado totalizante: o autor minimalista "produz uma versão (visão) parcial contida em um espaço tão cuidadosamente condensado que [o leitor] deve inferir a partir da parte exposta exatamente o que foi omitido, o que está subentendido, ou seja, a imagem inteira" (p.9, grifos nossos). ${ }^{28}$ Como vemos, o apego de Hallett à suposta obrigatoriedade de uma

\footnotetext{
${ }^{26}$ Precisamente a la anulación del texto narrativo.

27 Iftekharrudin (2003) explica o termo "realismo sujo" como um tipo de ficção cujo tema é "geralmente limitado a pessoas das classes socioeconômicas menos privilegiadas cujos padrões de vida contribuem para a superabundância de [famílias vivendo em] trailers, bairros desleixados, roupas de poliéster, bem como atividades de lazer que, de maneira estereotípica, denotam subemprego ou desemprego: alcoolismo frequente, jogos de azar, brigas, tédio etc." Esses temas são típicos da ficção de vários autores incluindo Raymond Carver, Anne Beattie, Richard Ford, Mary Robison, Bobbie Ann Mason, entre outros (p.xi). Outras referências a esse rótulo incluem Ruland \& Bradbury (1991, p.393) e Hemmingson (2008).

28 the whole of society reflected in slivers of individual experience. [...] produces a partial version (vision) contained in a space so carefully condensed that one must infer from the part exposed exactly what has been omitted, what lies beneath, i.e., the whole picture.
} 
correspondência exata entre o omitido e o expresso, entre o parcial e o total, levam-na a desconsiderar o aspecto fragmentário, indeterminado e árido de várias das manifestações do conto minimalista. Daniel Just, por exemplo, ao analisar o conto "So Much Water So Close To Home" (1981), de Carver, observa que a dominante nesse tipo de história são justamente os fragmentos, os detalhes descontextualizados, isto é, o fato de que com frequência "o todo escapa", ${ }^{29}$ o sentido não é recuperado (2008, p.305). E não obstante Hallett ressalte alguns traços pós-modernos no conto minimalista como o apagamento do estilo único, o uso de imagens superficiais e a convicção de que o mundo e a linguagem não são governados por regras e verdades estáveis (1999, p.16-17), sua avaliação geral do minimalismo indicia uma certa nostalgia em relação às formas mais "satisfatórias" do alto modernismo norteamericano.

Biguenet (1985) também não concorda com a "falta de estilo" do minimalismo e critica especialmente aspectos pós-modernos como o apagamento do estilo único e a presença autoral quase impassível. Segundo o crítico, "se o minimalismo é uma tentativa de escrever prosa sem estilo, então ele é uma tentativa de ser sem conteúdo também. O que sobra em tal literatura exceto uma voz disjuntiva, um eu antissocial, um solipsista, um sentimentalista?" (p.40). O maior problema, na opinião de Biguenet, é que esse tipo de ficção, ao evitar enredos totalizantes e confiar na "co-autoria" do leitor frente à sugestividade dos dados mínimos da narrativa, acaba por obliterar a noção de autor como gênio, como autoridade: "a ficção minimalista renuncia à autoridade e, de modo bastaste literal, os escritores minimalistas deixam de ser autores" (p.42). ${ }^{30}$

Stevenson (1985), por outro lado, observa que os autores vinculados ao minimalismo têm uma consciência aguda de seu papel na construção do texto. $O$ fato de suas ficções empregarem elementos superficiais e linguagem quase literal mostra que esses autores compartilham da concepção de que a realidade se define por uma sobreposição de superfícies. E o código literário minimalista, que, ao contrário do modernista, mostra um certo "desdém pela complexidade da percepção", consiste em uma tentativa de aplanar a palavra, mais do que de trabalhar em profundidade os possíveis desdobramentos de sentido do signo: "o trabalho do artista, [os autores minimalistas] creem, não é percepção, nem interpretação; o

\footnotetext{
${ }^{29}$ the whole escapes.

${ }^{30}$ If minimalism is an attempt to write styleless prose, then it is an attempt to be contentless as well. What is left in such literature except a disjunctive voice, an asocial self, a solipsist, a sentimentalist. [...] Minimalist fiction relinquishes authority, and so quite literally minimalist writers cease to be authors.
} 
trabalho do artista não está na mente, está na página. [...] O resto fica a cargo do leitor" (p.87). ${ }^{31}$ É evidente, portanto, a adesão de Stevenson às ideias de Roland Barthes quanto ao texto como uma rede de relações, uma partitura inacabada, que solicita ao leitor "uma colaboração prática" na produção do próprio texto, ou seja, em vez de consumi-lo de modo passivo, o leitor deve fazer parte do "jogo" (1977, p.163).

Abrams (1985), nessa mesma corrente, defende que no caso da ficção minimalista, sobretudo no caso de Carver e Beattie, há a predominância da abordagem superficial do universo ficcional, isto é, trata-se de mundos "em que personagens bem como autores não propõem nem superestruturas de significado, nem uma ideia [...]. O concreto ocupa uma posição de irredutível primazia" (p.25). ${ }^{32}$ Dessa maneira, o leitor não observa a narrativa de uma perspectiva elevada, nem tem acesso à vida interna das personagens nem à essência do mundo aparente uma vez que a paisagem humana e ficcional minimalista é achatada.

De acordo com Daniel Just, o incômodo de alguns setores da crítica quanto à falta de explicações, julgamentos e opiniões dos narradores minimalistas deve-se à dificuldade que os críticos (como leitores) têm em determinar por conta própria qual é a relação que esses textos estabelecem com os vícios e os modos de vida da classe média trabalhadora:

Pelo fato de que o tom descompromissado dessas histórias arruina a identificação fácil da relação da história com seu objeto de descrição, o leitor em geral se sente desorientado quanto ao propósito de tal narrativa. Motivados moralmente ou não, muitos críticos, por essa razão, sentem-se incomodados pelo tom impassível, que torna impossível determinar o modo como um certo texto se relaciona com o tédio das ações relatadas - a narrativa minimalista critica ou endossa o que descreve (seja consumismo, alcoolismo etc.)? $\left(2008\right.$, p.309). ${ }^{33}$

\footnotetext{
${ }^{31}$ The artist's business, they believe, is not perception, not interpretation; the artist's business is not the mind, it is on the page. [...] the rest is left to the reader.

${ }^{32}$ in which characters and authors alike propose no superstructures of meaning, no idea [...]. The concrete holds a position of unassailable primacy.

${ }^{33}$ Because the noncommittal tone of these stories undermines the easy identification of the story's relation to its object of description, the reader often feels disoriented about the purpose of such a story. Morally motivated or not, many critics are therefore disturbed by the detached tone that makes it impossible to determine how a given text relates to the tedium of its reported actions-does minimalist story criticize or endorse what it describes (be it consumerism, alcoholism, and so forth)?
} 
Em outras palavras, parte do desconforto de Biguenet diante da postura um tanto indiferente do narrador minimalista se deve ao fato de o julgamento crítico do teórico estar associado às formas mais familiares do conto e, sobretudo, a um tipo de narrador tradicional, que, ao reproduzir uma determinada visão de mundo, julga (de modo implícito ou não) as personagens e as situações, mostrando, assim, uma intencionalidade (1985, p.40). No caso do minimalismo, o texto apenas cria, pelas razões já mencionadas, a ilusão de ausência autorial, mas essa aparente falta de comentários explícitos acerca do conteúdo, que Biguenet equaciona a estilo, apenas reforça a noção de Jameson de que o pós-modernismo demarca "o fim [...] do estilo, no sentido do único e do pessoal, o fim da pincelada individual distinta" (2006, p.43). No entanto, a aparente "falta" de um modo peculiar de expressão ou o empréstimo de dados estilísticos do passado, muitas vezes percebidos na narrativa pósmoderna, constitui um estilo em si.

Diante do exposto, podemos notar vários pontos de convergência entre as características associadas ao estilo minimalista e alguns dos contos publicados por Noll e Shepard. Dessa forma, a interface com o conto minimalista tem uma influência decisiva em algumas vertentes do conto pós-moderno, sobretudo no tocante às questões envolvendo o narrador, que, como veremos, sofre uma diluição em seu papel como centro organizador da percepção, bem como o leitor, que pode experimentar certo grau de desorientação dadas as instabilidades do foco narrativo, o relativo esvaziamento de referências espaçotemporais e a supressão de dados das personagens. Nesse sentido, é possível perceber alguns traços minimalistas, além dos mais evidentes como a concisão extrema, a inércia do universo ficcional, as omissões drásticas, tanto em Shepard como em Noll.

Esses traços minimalistas, apesar de bastante recorrentes na ficção atual, não podem ser considerados uma dominante estética, dada a coexistência de outras vertentes literárias em atividade na produção narrativa recente. Em razão da grande diversidade de pósmodernismos, outras perspectivas como, por exemplo, o questionamento do registro histórico oficial, o mapeamento das sociedades do(a) vigilância / simulacro / consumo/ imagem, as experiências dos imigrantes, minorias etc., dão a tônica dos trabalhos de outros contistas contemporâneos, que muitas vezes preferem um estilo mais "substancioso" de narrativa em vez da prosa despojada do minimalismo literário, bem como formas mais familiares. Para fins apenas de comparação, entendemos por forma familiar o tipo de conto dotado de um padrão de enredo inteligível e que, em suas formas atuais, incorpora algumas das temáticas expostas acima, bem como soluções inovadoras, sendo capaz de fornecer ao leitor uma sucessão de 
acontecimentos intensos, criar suspense e algum tipo de resolução, ou seja, um tipo de conto que se define, nas palavras de Cortázar, inspiradas em Poe, como "uma verdadeira máquina literária de criar interesse" (1974, p.122-3).

\subsection{1 - Leituras do tédio}

As críticas contra o minimalismo, como vimos, tendem a focar justamente a suposta falta de criação de interesse nos leitores, que podem sentir-se frustrados em contato com a aparente ausência de "história" e a monotonia das "atmosferas" esboçadas por esses contos (HALLETT, 1999, p.15). O "problema", conforme Hallett e Biguenet sugerem, estaria relacionado ao fato de o conto minimalista, seja pela extrema brevidade, pelo tom opaco do universo projetado, ou pela ausência de acontecimentos, não possuir mecanismos, para adotarmos a metáfora de Cortázar, capazes de gerar "interesse" no leitor, como, por exemplo, uma narrativa envolvente ou a expectativa de determinada resolução.

Conforme veremos no próximo capítulo, embora seja muito difícil discutir a resposta do leitor individual a determinado artefato literário, alguns teóricos tendem a associar os contos minimalistas a sentimentos de desinteresse ou tédio (JUST, 2008, p.309) do leitor durante a interação com esses textos. Ainda que os autores em pauta, sobretudo Noll, apropriem-se desse sentimento de enfado como temática, nossa discussão não entra no mérito do tédio como tema recorrente na tradição literária, ou seja, o estudo do tédio aqui não possui qualquer ligação com o spleen romântico, baudelariano, nem com os sentimentos de acédia ou desejo de evasão, nem com as preocupações metafísicas do tédio existencialista de Sartre. Em outras palavras, não abordamos essa questão como um tema caro à chamada "literatura do tédio" (LEROUX, 2008), mas como uma possível reação subjetiva, ou seja, extratextual, do leitor a determinados aspectos de um produto cultural. Além disso, há uma grande diferença entre o tédio apenas como temática e o tédio como possível resposta do leitor a certos aspectos de um texto. O tema da tediosa espera em agonia que precede o falecimento do protagonista da novela A morte de Ivan Ilitch (1886), de Tolstói, por exemplo, costuma resultar em uma leitura nada maçante (MESSUD, 2009, p.57).

A problemática do tédio como resposta ao objeto artístico tem sido analisada sob diferentes ângulos nas últimas décadas. Barthes, por exemplo, ao tratar da passagem do 
conceito de obra para uma noção mais lúdica e interativa de texto, em que escrita e leitura tornam-se atividades simbiônticas, observa que muitos leitores, sobretudo os mais predispostos a "consumir" de modo mais ou menos passivo a "obra", relatam a experiência de tédio "em face do texto ('ilegível') moderno, do cinema e da pintura vanguardistas". ${ }^{34}$ Barthes observa que esse tédio na verdade tem que ver com a incapacidade do leitor, como vimos, de "colaborar", isto é, de trabalhar em parceria com o autor na produção do próprio texto. Segundo o crítico, "sentir-se entediado significa que não se consegue produzir o texto, ampliá-lo, acioná-lo" (1977, p.163). ${ }^{35}$ A definição de Barthes parece, no entanto, não levar em consideração o fato de que alguns desses textos, sobretudo os associados ao minimalismo, fazem uso deliberado de técnicas que tendem a ser menos "interessantes" para o leitor. Em outras palavras, o tédio em alguns contos minimalistas e pós-modernos pode estar mais ligado a uma escolha consciente do autor em provocar essa determinada resposta do que propriamente com uma "incapacidade" do leitor em "jogar" com os elementos textuais.

O estudo de algumas dessas características vinculadas ao minimalismo contribui para a compreensão das escolhas estéticas de Sam Shepard em Great Dream of Heaven. Como o capítulo III buscará deixar claro, esta é uma coleção de histórias desiguais, fragmentárias, porém muitas delas mobilizam um tipo de narração impassível, repleta de zonas indeterminadas, que projeta um universo ficcional reduzido aos seus traços constituintes mínimos. Kakutani (2002) classifica a linguagem utilizada por Shepard nesta coleção, em comparação com textos anteriores do autor, como "mais chata" e com menos registros do falar regional. Por essa razão, a crítica avalia que alguns textos do livro "quase evaporam da página", falhando assim em "se insinuar, mesmo de maneira momentânea, na mente do leitor" (p.7). ${ }^{36}$ As observações de Kakutani deixam claros tanto o tédio quanto a falta de interesse que algumas das histórias podem provocar em alguns leitores; contudo, sua avaliação não parece ter um tom negativo. Isso mostra que alguns desenvolvimentos do conto pós-moderno violam orientações convencionais do gênero, conforme sintetizadas a seguir por Massaud Moisés, segundo as quais o conto tradicional distingue-se pela necessidade de impactar o leitor ou de mobilizar sua atenção e, por conseguinte, estimular seu interesse (no sentido positivo):

\footnotetext{
34 in the face of the modern ('unreadable') text, the avant-garde film or painting.

${ }^{35}$ to be bored means that one cannot produce the text, open it out, set it going.

${ }^{36}$ nearly evaporate off the page, failing to insinuate themselves, even momentarily, in the reader's mind.
} 
A posição do leitor diante do conto é de quem deseja, à pressa, desentediar-se e, mesmo, enriquecer-se mentalmente. [...] Procura ele [o leitor] no conto especialmente o desenfado e o deslumbramento perante o talento que alcança pôr em reduzidas páginas tanta humanidade em drama (1975, p.144, grifos nossos).

Como observa Jameson, no entanto, o tédio despertado por alguns objetos estéticos pós-modernos pode ser lido como resposta estética e interpretado de maneira produtiva:

Tanto na tradição freudiana quanto na marxista [...] o 'tédio'
é considerado não tanto como uma propriedade objetiva das
coisas, mas como uma resposta ao bloqueio das energias
(quer sejam entendidas em termos de desejo ou de práxis). O
tédio torna-se interessante como reação a situações de
paralisia, mas também, sem dúvida, como um mecanismo de
defesa ou comportamento de escape. Mesmo considerado no
domínio mais estreito da recepção cultural, o tédio em
relação a um tipo de trabalho, ou estilo, ou conteúdo, sempre
pode ser usado de maneira produtiva como sintoma valioso
de nossos próprios limites existenciais, ideológicos e
culturais, um índice do que temos que recusar nas formas de
prática cultural dos outros, e da ameaça que esta representa
para a nossa própria racionalização sobre a cultura e o valor
da arte (2006, p.95).

Narrativas como Canoas e marolas (1999) e Berkeley em Bellagio (2002) de João Gilberto Noll, de maneira geral, incorporam o tédio como temática, mas podemos dizer que em Mínimos, múltiplos, comuns, a experiência do tédio, ou ao menos um relativo desinteresse, por parte do leitor, pode ocorrer por uma série de razões: a principal delas refere-se ao fato de que os textos, em virtude das imposições quanto ao limite reduzido da coluna em que Noll publicou os textos, conservam o aspecto de ficção ligeira, com pouquíssimas personagens, situações pouco desenvolvidas em termos de ações, podendo ser lidos em segundos. Como vimos no início deste capítulo, vários contistas e teóricos creem que o interesse do leitor depende de estímulos sob a forma de personagens interessantes, gradação tensiva, criação de uma narrativa envolvente, entre outros recursos. Dessa maneira, há a hipótese de que os textos de Mínimos, múltiplos, comuns possam suscitar o desinteresse no leitor, pois seriam breves ou efêmeros demais para construir com uma certa profundidade 
esses elementos e, sobretudo, "insinuar-se" na mente do leitor e despertar-lhe o interesse e a atenção.

A segunda possibilidade, baseada em Jameson, diz respeito ao tédio como reação a "situações de paralisia", que encontramos em vários dos contos de Noll e Shepard, nos quais nada em termos de ação propriamente dita acontece e as personagens parecem estagnadas em meio a situações monótonas. Brooks (2002), por exemplo, nota que as frases finais de vários dos contos de Great Dream of Heaven flagram as personagens em situações malresolvidas, cuja condição é de profunda inércia: “'Ele permanece desse jeito' ('The Stout of Heart'); 'Não tenho planos' ('Living the Sign'); 'Não há nada a fazer' ('Betty’s Cats'). O fecho da décima história, 'Concepción', poderia se destacar como o princípio norteador da coleção como um todo: 'Eu os observei bem de perto, mas eles não se moveram de modo algum'” (p.26). ${ }^{37}$

Outra possibilidade refere-se ao tédio como resposta a um "bloqueio de energias", que pode ser experimentado pelo leitor durante a leitura de textos indeterminados como, por exemplo, "Ninguém". Este conto, como já mencionado, bloqueia o processamento cognitivo do enredo. A última possibilidade também é baseada em Jameson, que relata a experiência do tédio associada à repetição, imutabilidade ou longa duração, em termos relativos, de um determinado objeto cultural (2006, p.96). De maneira similar, Butler (2002) também associa o tédio a traços minimalistas como a falta de complexidade formal e expressiva, isto é, aspectos que, de acordo com o autor, não atraem o olhar do expectador nem são capazes de manter seu interesse (p.1-2). Dessa maneira, é provável que o leitor de um livro como Mínimos, múltiplos, comuns experimente, em algum momento, certo nível de enfado diante da sucessão de 338 narrativas aparentemente simples que, em geral, compartilham do mesmo limite físico e repetem um padrão narrativo semelhante em termos de indeterminações, carência de referentes espaçotemporais, fragmentação e falta de resoluções no sentido tradicional.

Nesse caso, duas observações se fazem necessárias: não se está querendo dizer que a possibilidade de alguns dos contos pós-modernos inspirarem tédio no leitor seja vista de maneira negativa. Segundo Jameson, devemos “despir o conceito de tédio (e sua experiência)

\footnotetext{
37 "He stays like that" ("The Stout of Heart"); "I have no plans" ("Living the Sign"); "There's nothing to do" ("Betty's Cats"). The close of the 10th story, "Concepcion", could stand as the guiding principle for the collection as a whole: "I watched them very closely but they never moved at all."
} 
de qualquer matiz axiológico e colocar toda a questão do valor estético entre parênteses" (2006, p.95). Dessa maneira, o tédio não como critério de valor, mas como conceito crítico, pode contribuir para a análise do fazer literário contemporâneo, pois textos que suscitam, de maneira mais ou menos consciente, essa resposta do leitor violam as concepções tradicionais de conto, que enfatizam a necessidade do uso de mecanismos literários capazes de produzir interesse. Dessa forma, o conto pós-moderno mostra sua adesão a uma gama plural de possíveis respostas em vez de se ater à busca de uma única possibilidade (o conto “interessante”). A segunda observação diz respeito à leitura. Como se trata de um ato muito particular e tende a variar de acordo com cada leitor, cultura, período histórico etc. - ou seja, pode-se dizer que "há tantas leituras quanto leitores" (SUTHERLAND, 1990, p.822) ${ }^{38}$ e que a reação do leitor aos estímulos textuais é apenas um momento dentro das complexas relações envolvendo literatura e sociedade (cf. HOHENDAHL, 1977, p.31) — o tédio como resposta estética a determinados objetos é concebido aqui apenas como hipótese analítica, uma vez que, como o próprio Jameson faz questão de salientar, não se trata de uma propriedade objetiva dos produtos culturais (2006, p.95).

A possibilidade do tédio como resposta do leitor durante a interação com a linguagem "chata" de Shepard, no dizer de Katutani (2002), que muitas vezes "deixa os leitores esperando mais" (VOGELIUS, 2003, p.1), ${ }^{39}$ ou com a grande quantidade de microcontos fragmentários e indeterminados de Noll, tende a ocorrer, pois, se tomarmos como base as ideias de Jameson, esses textos pós-modernos atuam no sentido de bloquear as energias do leitor. A literatura, de maneira geral, mobiliza essas energias, acionando tanto a esfera da práxis, materializada por meio da tentativa de processamento textual e concretização do texto, quanto a esfera dos desejos, expectativas, que ocorre por meio do estímulo da nossa imaginação, criando a ilusão de que "enquanto lemos, somos transportados para um território fora da nossa existência corpórea", como se tivéssemos a ilusão de viver "uma outra vida" (ISER, 2000, p.312). ${ }^{40}$

No contexto específico do conto pós-moderno, um texto indeterminado e marcado por traços minimalistas como "Ninguém”, de João Gilberto Noll, na prática, bloqueia as energias despendidas pelo leitor durante a atividade de processamento textual em decorrência das

\footnotetext{
38 there are as many readings as readers.

${ }^{39}$ leave readers waiting for more.

${ }^{40}$ while reading, we are transported to a realm outside our bodily existence, having the illusion of leading another life.
} 
descontinuidades e indeterminações quanto às coordenadas espaçotemporais. No que se refere à dimensão cognitiva, esse conto frustra as expectativas do leitor, que não consegue chegar a uma compreensão totalizante dos eventos narrados, experimentando, assim, uma potencial frustração de seus desejos e expectativas.

Os contos pós-modernos de Noll e Shepard, ao incorporarem dados carentes de totalização e elementos indeterminados à trama narrativa, propiciando ao leitor um relativo bloqueio de energias despendidas e jogando com seus "desejos" por resultados, instaura uma espécie de provocação inerente à atividade de leitura. Eagleton, por exemplo, associa a indeterminação na literatura a "uma espécie de equivalente poético da provocação erótica", ${ }^{41}$ que o texto realiza com o leitor ao fazê-lo "adivinhar" alguns elementos que omite (2007, p.130). Mas em se tratando de textos pós-modernos como "Ninguém", que desestabilizam violentamente os referenciais espaçotemporais, amortecendo as tensões dos acontecimentos e minando assim o clímax narrativo, é mais provável que ao invés de excitação, tenhamos como resposta a essa "provocação" um sentimento mais próximo do desinteresse ou do tédio uma vez que, como vimos, não se trata de um número reduzido de omissões, mas de diversas histórias em que se projeta um universo ficcional composto a partir de uma colagem de imagens indeterminadas e instáveis cujo processamento cognitivo é truncado.

Analisadas por esse ângulo, essas narrativas, cuja leitura tende a causar tédio em vez de despertar interesse e surpresa, representam o processo de esmaecimento dos afetos, das emoções em um sentido mais eufórico, ao qual Jameson se referiu ao examinar o panorama das artes na pós-modernidade (2006, p.43), momento definido por John Updike como "uma era de anticlímax" $\left(2009\right.$, p.68). ${ }^{42}$

Leituras do tédio como possível resposta às indeterminações e lacunas do texto, conforme veremos a seguir, também mantêm certa relação com o deslocamento para segundo plano da tradicional dimensão epistemológica do conto e a consequente emergência da polaridade ontológica como dominante estética nos produtos culturais contemporâneos.

\footnotetext{
${ }^{41}$ a kind of poetic equivalent to erotic teasing [...].

${ }^{42}$ an age of anticlimax.
} 


\section{5 - Dominante ontológica}

Seja por oferecer resistência ao escrutínio cognitivo do leitor, seja por constituir-se em um mundo que não se dá a conhecer, podemos pensar no universo ficcional projetado pelo conto "Ninguém" como um emblema justamente dessa negatividade: uma zona repleta de instabilidades, cujo conhecimento totalizante não é possível. O narrador-protagonista também se constitui como uma subjetividade em crise, que não é capaz de se sustentar como um centro organizador da percepção, isto é, como um eu centrado, e, a partir dessa subjetividade consistente, ir relatando o entorno. Desse modo, o conto de Noll se atualiza como uma resposta literária à profunda crise do conhecimento na pós-modernidade:

O conhecimento não só se tornou incerto, mas, o que é mais importante, a questão como um todo de como legitimar certas formas de conhecimento e certos conteúdos do conhecimento está firmemente [estabelecido] na agenda: nem um único modo satisfatório de legitimação epistemológica está disponível. Mesmo que algum estivesse, o próprio Sujeito da consciência foi, como resultado da desconstrução e da psicanálise, posto em dúvida [...] (DOCHERTY, 1993, p.4). ${ }^{43}$

Em um texto pós-moderno como "Ninguém", de Noll, e "Tinnitus", de Shepard, conforme veremos, o acúmulo de dados narrativos (ou, em termos jornalísticos, "informações") não gera, ao "final" do processamento cognitivo, um determinado conhecimento, ao menos em termos convencionais, sobre o universo e os seres ficcionais. Em outras palavras, os textos em pauta contrariam as convenções tradicionais do gênero segundo as quais, no conto típico, "os pormenores vão-se acumulando numa ordem 'lógica' de fácil percepção" (MOISÉS, 1975, p.133) - ao dificultar a atividade perceptiva por meio da instalação de desordens espaçotemporais, situações "incoerentes" e indeterminações.

Como mencionamos, críticos como McHale (1987) e Connor (2004) reconhecem uma dominante de ordem ontológica em grande parte da narrativa pós-moderna uma vez que esses

\footnotetext{
${ }^{43}$ Not only has knowledge become uncertain, but more importantly the whole question of how to legitimise certain forms of knowledge and certain contents of knowledge is firmly on the agenda: no single satisfactory mode of epistemological legitimation is available. Even if it were, the very Subject of consciousness has, as a result of deconstruction and psychoanalysis, also been thrown into doubt.
} 
textos revelam uma preocupação com a "criação e a interrelação dos mundos do ser", isto é, os autores vinculados ao pós-modernismo, conscientes das dificuldades de legitimação envolvidas nos processos de compreensão e "testemunho do mundo", parecem mais inclinados a questões relacionadas à "feitura" desse território ficcional ou à "navegação" por esse universo imaginário e, dessa forma, esses fazeres tendem a "gerar novos mundos ou estados de ser" (CONNOR, 2004, p.65-66). ${ }^{44}$

Em se tratando de muitos dos contos pós-modernos de Noll e Shepard, bem como alguns dos textos associados ao minimalismo, há uma aparente vocação desse tipo de narrativa no sentido de ser um fragmento, um instante ficcional, uma intervenção mínima, que "evapora" da página, ao invés de constituir uma experiência grandiosa, um todo orgânico ou uma obra de arte pensada para durar no imaginário do leitor. Brooks, por exemplo, observa que "Shepard construiu um corpo de trabalhos [em Great Dream of Heaven] que é aberto e fragmentário; incompleto e que se orgulha de assim sê-lo" (2002, p.26). ${ }^{45}$ Essa ideia coaduna-se com a afirmação de Anderson, inspirada em Jameson, de que no pós-modernismo “o tempo das grandes assinaturas e obras-primas do modernismo terminou” dando lugar a uma espécie de nivelamento que acompanha a ordem econômica em vez de se opor a ela como faziam as obras-primas vinculadas ao modernismo $\left(1998\right.$, p.63,93). ${ }^{46}$

\footnotetext{
44 creation and interrelation of worlds of being [...]. to generate new worlds or states of being.

${ }^{45}$ Shepard has built up a body of work that is open-ended and fragmentary; incomplete and proud of it.

${ }^{46}$ the time of the great signatures and master-works of modernism was over.
} 


\title{
Capítulo II
}

\section{INDETERMINAÇÕES E PROCESSOS PARATÁTICOS EM NARRATIVAS DE JOÃO GILBERTO NOLL}

\begin{abstract}
Os eventos narrados [em textos de Noll] não formam um conjunto de experiências que determina ou revela o percurso do protagonista em direção a determinado fim — nem mesmo um processo frustrado. Ao contrário, a narrativa apresenta a mera sucessão de eventos não relacionados, que não formam um todo orgânico. A enumeração dos acontecimentos pode nos dar a dimensão da aleatoriedade com que os fatos se sucedem, ou pelo menos tornar mais clara a ausência de encadeamento presidido pela causalidade rigorosa.
\end{abstract}

Edu Teruki Otsuka, 2001, grifos nossos

A questão da indeterminação é mesmo forte no meu trabalho. De uma certa forma, em mim; faz parte de um plano inconsciente, digamos. É minha sensação mestra na escrita. ${ }^{1}$

João Gilberto Noll, 2007

Violações na sequencialidade narrativa, supressões radicais de dados contextuais envolvendo personagens e situações, bem como sujeitos e focos narrativos instáveis, entre outros, compõem o variado repertório de procedimentos ficcionais que associamos às indeterminações narrativas (cf. PERLOFF, 1993).

A incorporação deliberada desses aspectos por algumas formas textuais não se restringe, no entanto, a produções recentes. A teórica Sarah Skrainka, em L'Enfant de sable: roman de l'ambiguïté (1993), associa as formas de ambiguidade e indeterminação — que a pesquisadora entende como "interrupções e rupturas na continuidade e na cronologia da intriga; narradores múltiplos e não confiáveis; ambiguidades e lacunas no texto; contradições",2 - tanto à tradição dos relatos orais como ao pós-modernismo (p.3). Desse modo, embora a origem de práticas textuais ambíguas e indeterminadas remonte à antiga

\footnotetext{
${ }^{1}$ Ref. correspondência pessoal com o autor [cf. Anexo].

${ }^{2}$ interruptions et ruptures dans la continuïté et la chronologie de l'intrigue; narrateurs multiples et non fiables; ambiguïtés et blancs dans le texte; contradictions.
} 
tradição oral, encontramos evidências de que essas estratégias têm dado a tônica de numerosos produtos culturais contemporâneos.

Conforme argumenta Umberto Eco, no livro Obra aberta: forma e indeterminação nas poéticas contemporâneas, a arte recente tende a aceitar e tentar dar forma à provocação do acaso, do ambíguo, do provável revelado pelo desenvolvimento de hipóteses teóricas como as da indeterminação, da probabilidade estatística, dos modelos explicativos provisórios e variáveis. Os artistas, nessa mesma esteira, têm buscado mapear com seus artefatos estéticos essa "desordem". Porém, não se trata de uma desordem incurável, a "derrota de toda possibilidade ordenadora" (1969, p.23), mas de uma desordem fecunda, que visa provocar a ruptura de uma “ordem tradicional”, unívoca e fechada, e estimular um tipo de fruição da obra de arte que é, ao mesmo tempo, inventiva e aberta (1969, p.41-42).

Esse investimento em favor da ruptura de uma "ordem tradicional" é explicitamente assumido por João Gilberto Noll, ${ }^{3}$ que, em seu trabalho como ficcionista, contempla a incorporação de dados provisórios e indeterminados como forma de tentar obliterar a sequencialidade automática da percepção. Diante disso e da relevância artística de elementos indeterminados no trabalho de Noll, conforme destaca o próprio autor na epígrafe acima, examinamos, a seguir, aspectos teóricos das indeterminações literárias.

\subsection{Indeterminações}

No âmbito das produções literárias, as indeterminações podem ser definidas, segundo Eagleton (1983), como "elementos que dependem, para atingir seu efeito, da interpretação do leitor e que podem ser interpretados de maneiras diferentes, talvez até mutuamente conflitantes" (1996, p.66). ${ }^{4}$ Nesse sentido, a indeterminação, conforme expõe o autor em estudo mais recente, difere da ambivalência, pois esta ocorre quando nos deparamos com uma passagem, verso ou texto em que há a sugestão de dois significados possíveis, sendo que ambos são determinados, porém diferem entre si (2007, p.125, grifo nosso). As

\footnotetext{
${ }^{3}$ NOLL, João Gilberto Noll. Estilo e somatização. Conferência proferida durante a abertura do X SEL SEMINÁRIO DE ESTUDOS LITERÁRIOS, 2009, São José do Rio Preto - SP: UNESP - Universidade Estadual Paulista, Instituto de Biociências, Letras e Ciências Exatas, 13 de outubro de 2009.

${ }^{4}$ elements which depend for their effect upon the reader's interpretation, and which can be interpreted in a number of different, perhaps mutually conflicting ways.
} 
indeterminações (que, para o autor, incluem formas de ambiguidade), por outro lado, são criadas quando estamos diante de palavras ou passagens de certos textos em que se abrem mais de duas possibilidades de leitura, isto é, em que "dois ou mais sentidos [...] fundem-se a tal ponto que o significado em si torna-se indeterminado" (p.125), permitindo interpretações alternativas (p.165). ${ }^{5}$

Embora ocorram de maneira menos frequente se comparadas às ambivalências e aos chamados "finais abertos", as indeterminações constituem um aspecto recorrente de diversos artefatos literários. Anatol Rosenfeld, seguindo as teorias da recepção desenvolvidas por Roman Ingarden e Wolfgang Iser, atesta que a obra de arte literária, entendida como um discurso constituído por "objectualidades puramente intencionais" projetadas pela camada verbal, sempre apresentará vastas regiões indeterminadas, em virtude de personagens e situações serem sempre configurações esquemáticas (1998, p.15-16,33). Rosenfeld, no entanto, sugere que o papel do leitor consiste em completar essas vastas "zonas indeterminadas", pois este "atualiza" o conteúdo da obra e "ultrapassa" os dados projetados pelo texto. Essa atividade de encobrir as áreas de indeterminação do texto é realizada graças à “imaginação concretizadora do apreciador” (Id., ibid., p.14).

O problema com esse tipo de tratamento das indeterminações, conforme já apontou Eagleton (1996, p.69-71), consiste em trazer implícita a ideia de que as ambiguidades, fragmentações e zonas indeterminadas do texto devem ser abolidas em nome de um sentido estável, isto é, “devem, segundo o termo autoritário e revelador de Iser, ser 'normalizadas' — subjugadas e submetidas a uma certa estrutura firme de sentido" (EAGLETON, 1996, p.71). ${ }^{6}$ Essa atividade de normalização das zonas indeterminadas pressupõe um sujeito-leitor unificado, capaz de perceber, conforme sugere Iser em recente artigo, "o valor manifesto na reconciliação harmoniosa das ambiguidades textuais" (2000, p.311). ${ }^{7}$

Textos pós-modernos, como alguns dos contos de Noll e Shepard, no entanto, tendem a resistir à atividade de reconciliação harmoniosa (em um sentido linear e convencional) dos elementos incertos, que permanecem "indecidíveis" no âmbito da economia narrativa. Muitos dos traços incongruentes, fragmentários e indeterminados nesses textos contemporâneos não podem ser "harmonizados", no sentido de que não podem ser conformizados a fim de se obter algum modelo estável, harmônico ou totalizante. Nesse sentido, o teórico Brian McHale

\footnotetext{
${ }^{5}$ two or more senses [...] merge into each other to the point where the meaning itself becomes indeterminate.

${ }^{6}$ They must, in Iser's revealingly authoritarian term, be 'normalized' - tamed and subdued to some firm structure of sense.

${ }^{7}$ the value manifested in the harmonious reconciliation of textual ambiguities.
} 
distingue dois tipos de indeterminações com os quais podemos nos deparar nos textos pósmodernos e que nem sempre poderão ser levados a "bom termo" pelo leitor:

Parte da indeterminação dos mundos ficcionais e dos objetos [inseridos] neles é permanente: nunca seremos capazes de fechar a lacuna. Outras lacunas, no entanto, são temporárias, projetadas para serem preenchidas pelo leitor no processo de percepção ou concretização do texto $\left(1992\right.$, p.36). ${ }^{8}$

Por não partilhar desse modelo "saudável” de leitura e textualização, Eagleton prefere definir as indeterminações como falta de sentido claro ou exato (2007, p.167) e, ao analisar um dos sonetos de Shakespeare contendo indeterminação do sentido, comenta que essa técnica serve para manter o leitor na tentativa de adivinhar o sentido, de pegá-lo desprevenido, pois essa estratégia evita justamente um tipo de interpretação que tende a "sedimentar-se em uma atitude única, unívoca" (Id., ibid., p.130). ${ }^{9}$

Hassan também aceita (e até certa medida, celebra) o caráter "humano e inconclusivo" das indeterminações, salientando o fato de que, devido à sua propensão a materializar-se em nossa cultura sob múltiplos "disfarces" — processos paratáticos, colagens, montagens, música aleatória, happenings, arte cinética, minimalismos, poesia concreta, formas descontínuas, lúdicas ou autorreflexivas, entre outros —, esses traços indeterminados tendem a "retardar fechamentos, frustrar expectativas, promover abstrações, admitir uma pluralidade lúdica de perspectivas e desestabilizar, de maneira geral, a base do sentido junto ao público" (1987, p.73). ${ }^{10}$

Algumas das práticas artísticas listadas acima por Hassan como exemplos de "disfarces" assumidos pelas indeterminações na cultura contemporânea são também citadas por Calabrese (1999). Essas manifestações indeterminadas, bem como outras formas de indefinição, vagueza, imprecisão etc., são retomadas pelo crítico italiano como traços distintivos de diversos produtos culturais da contemporaneidade ou, como prefere Calabrese, da "era neobarroca" na qual nos encontraríamos atualmente. Tais manifestações artísticas, regidas, segundo a terminologia do autor, pelas categorias do "mais ou menos" ou do "não sei

\footnotetext{
${ }^{8}$ some of the indeterminacy of fictional worlds and the objects in them is permanent: we will never be able to close the gap. Other gaps, however, are temporary, designed to be filled in by the reader in the process of realizing or concretizing the text.

${ }^{9}$ to sediment into a single, unequivocal attitude.

${ }^{10}$ Human and inconclusive [...] to delay closures, frustrate expectations, promote abstractions, sustain a playful plurality of perspectives, and generally shift the grounds of meaning on their audiences.
} 
o quê", dependem estritamente do sujeito, pois referem-se "a um sentir, a um dizer, a um ver, a um escutar, a um perceber do sujeito ante o objeto". ${ }^{11}$ Dessa maneira, Calabrese sugere que as práticas indeterminadas que perfazem a noção da chamada estética do "mais ou menos" são “o resultado de uma incapacidade 'parcial' de definição do objeto por parte de um sujeito 'débil' (1999, p.175). ${ }^{12}$

De maneira mais específica, essas percepções indeterminadas, vagas e indefinidas dizem respeito a formas "débeis" de "actorialização" (atuação do sujeito), "espacialização" (representação da espacialidade) e "temporalização" (representação da temporalidade). Essas debilidades, no caso de obras literárias ou outros produtos artísticos marcados pelas indeterminações ou pela estética do "mais ou menos", referem-se aos seguintes "problemas": i) de "actorialização", isto é, "não se consegue enfocar o objeto ou este é deliberadamente desfocado"; ii) "Espacialização", pois "não se consegue fixar o contorno, o perfil, o limite do objeto devido à distância equivocada entre sujeito e objeto ou produz-se uma distância inadequada; e iii) de "temporalização", pois "falta a capacidade de deter a duração do objeto (em especial, sua simultaneidade)" (Id., ibid., p.175). ${ }^{13}$

Dada a "debilidade" demonstrada pelo sujeito recorrente nos textos de Noll, tornam-se evidentes os exemplos de formulações problemáticas ou "parciais" dos princípios de actorialização, espacialização e temporalização em grande parte dos textos de Mínimos, múltiplos, comuns. Ao formularem de maneira parcial as coordenadas espaçotemporais da narrativa, ao solaparem os nexos de causalidade natural e ao colocarem em cena um narradorpersonagem incapaz de dar um sentido claro às experiências vividas, os textos indeterminados de Noll põem em evidência questões vinculadas à incapacidade do sujeito de apreender de modo totalizante o real em um contexto em que as certezas não estão mais disponíveis.

No plano ficcional das narrativas de Noll, associamos essa sensação de incerteza às variadas formas mobilizadas pelo autor como, por exemplo, indeterminações, passagens minimalistas, aleatoriedades, fragmentações e outras "sequelas do subdesenvolvimento" narrativo, às quais alude a personagem escritor (alter ego de Noll) no romance Berkeley em Bellagio (2003b, p.59-60). Portanto, mais do que buscar o valor tradicional contido na "reconciliação harmoniosa das ambiguidades textuais", como recomenda Iser (2000, p.311),

\footnotetext{
${ }_{11}^{11}$ a un sentir, a un decir, a un ver, a un escuchar, a un percibir del sujeto ante un objeto.

12 el resultado de una parcial 'incapacidad' de definición del objeto por parte de un sujeto 'débil'.

13 'Actorialización': no se consigue enfocar el objeto o se desenfoca adrede. 'Espacialización': no se consigue aferrar el contorno, el perfil, el confín del objeto a causa de la distancia equivocada entre sujeto y objeto o se produce una distancia inadecuada. 'Temporalización': falta la capacidad de detener la duración del objeto (especialmente su instantaneidade).
} 
as narrativas de Noll optam por multiplicar essas ambiguidades e indeterminações, bem como promover "desarranjos" textuais, que se materializam sob a forma de omissões, rupturas, processos paratáticos, entre outros, e cuja leitura pode resultar em uma experiência frustrante dada a dificuldade ou mesmo impossibilidade de arregimentar muitas dessas "incongruências" narrativas.

Dentre esses procedimentos artísticos que, entre outros efeitos de sentido, podem eclipsar reconciliações textuais ditas "harmoniosas", justamente por promoverem indeterminações, conforme observa Hassan (1987, p.73), um dos mais relevantes é a utilização de processos paratáticos, de que tratamos a seguir.

\subsection{Parataxe}

O estilo paratático está longe de ser um recurso novo (cf. STAIGER, 1975, p.42; AUERBACH, 2004, p.100) - Aristóteles, no livro III da Retórica, já postulava que o orador deveria evitá-lo, por tratar-se de um estilo “desagradável” (1959, p.9) ao ouvinte —, mas esse recurso possui um papel relevante tanto em alguns contos de Noll e Shepard como na narrativa contemporânea em geral. Italo Moriconi, por exemplo, ressalta "a importância da retórica do paradoxo e das sintaxes paratáticas" como uma das características formais mais marcantes do pós-modernismo (2005, p.356). ${ }^{14}$

Como sabemos, a parataxe, em princípio, consiste em um processo sintático no qual, ao contrário das formas de organização hipotática, as orações são desprovidas de conexões rigorosas, ou seja, as orações são meramente justapostas. O termo "parataxe" provém da junção de duas palavras de origem grega - o prefixo "para-", que significa "ao lado" e o radical "táxis", que quer dizer "arranjo, ordem, classificação" - e se refere a um tipo de arranjo em que as orações mantêm, ao menos no nível sintático, uma relativa independência entre si. No campo literário, o conceito de parataxe foi reelaborado por teóricos e seu sentido, inicialmente vinculado apenas à retórica e à gramática, foi expandido para os efeitos de sentido poético que esse estilo pode instaurar em um texto.

Erich Auerbach, em estudo da representação da realidade na epopeia Canção de Rolando, associa o emprego da sintaxe paratática a efeitos de natureza plástica no texto, pois

\footnotetext{
${ }^{14}$ the importance of rhetorics of paradox and paratactic syntaxes.
} 
essa técnica dilui uma "cena" em uma série de pequenas parcelas acidentadas e tende a afrouxar a relação explicativa entre esses "quadros estáticos" e a ressaltar a energia marcante dos gestos captados no "instante cênico" (2004, p.100). Podemos notar esses efeitos de sentido no microconto "Na correnteza", de João Gilberto Noll. Nesse texto, as pequenas imagens desconectadas são justapostas de maneira aleatória diante do leitor: "Na estação de superfície, o velho ronca. A criança corre, quase despenca sobre os trilhos. A nuvem se desfaz na placa espelhada. [...] Quem olha tais mutações?” (2003a, p.33). Trata-se de imagens superficiais, que não se concatenam de maneira sintática, e que são dispostas lado a lado diante do leitor para que este contemple esses breves instantes plásticos e semiestáticos em sua fugaz fragilidade, sem a preocupação de determinar a ordem dos fatos ou a relação dessas imagens entre si.

Silva (1981), no livro Análise do texto literário: orientações estilísticas, analisa as distinções entre parataxe e hipotaxe em termos de produção de sentido. Segundo o pesquisador, uma obra que privilegia a relação paratática entre as orações tende a conferir um tom mais emotivo ao relato, instaurando uma espécie de "visão sentimental do mundo". Silva explicita essa noção nos seguintes termos:

[Em um texto cuja organização paratática é predominante] a relação conceitual se afrouxa, ganhando relevo uma expressão em que o afetivo supera a representação cognitiva ou puramente intelectiva. Com essa organização, que domina na linguagem falada, parece que os escritores preferem marcar um tom emotivo ou criar uma atmosfera de espontaneidade, reforçando a visão sentimental do mundo, visão que tende menos a selecionar do que a tudo aproveitar, menos a hierarquizar do que simplesmente a alinhar, sem interpretações reflexivas (p.122).

Podemos observar a atualização desse efeito de sentido na seguinte passagem do conto "Blinking Eye", de Sam Shepard. Nesse texto, uma jovem atravessa o país de carro, levando no banco do passageiro apenas uma urna funerária de cerâmica verde contendo as cinzas de sua mãe, motivo que será retomada no roteiro escrito e estrelado por Shepard para o filme Estrela solitária (Don’t Come Knocking, 2005), do diretor Wim Wenders (Fig. 2). Na seguinte passagem do conto, a protagonista confronta-se com um falcão ferido no meio da estrada.

Ela quer desatar em pranto. Quer arrumá-lo completamente e acabar com tudo isso. Ela dança em círculos estreitos no meio da rodovia vazia[...]. "Oh, Deus! Oh, Deus! Oh, Deus!” ela grita. Nada responde. Ela estaca. O falcão também estaca e simplesmente a fita com seu 
olho amarelo piscando, a pupila escura fria como uma pedra, no centro. Seu bico está bem aberto, ofegante. Ela consegue enxergar a ponta rósea de uma língua. [...] O pássaro apenas pisca. Sua cabeça move-se rapidamente de um lado para o outro, espantado (2002a, p.27). ${ }^{15}$

Nessa breve passagem, observamos a protagonista do conto enquanto esta se esforça, com enorme dificuldade, para capturar um falcão ferido usando apenas um casaco de moletom. Sua fatigante tentativa de segurar a ave convulsa é decomposta em um painel de pequenas ações: ela sente desespero, dança em círculos, grita, observa a língua do pássaro. $\mathrm{O}$ falcão também executa pequenas ações como piscar, ofegar, contorcer-se etc. Esses breves acontecimentos são mais ou menos independentes entre si, havendo, portanto, a possibilidade de representá-los em uma ordem diversa da apresentada pelo texto sem alterar substancialmente o sentido da passagem. Dessa forma, a protagonista poderia ter gritado antes de querer desatar em pranto; o pássaro poderia mover-se rapidamente antes de estacar e piscar; a mulher poderia dançar em círculos após observar a língua da ave etc.

$\mathrm{Na}$ referida passagem, há uma imbricação de uma série de pequenas orações caracterizadas pelo predomínio da parataxe, pois se trata de várias proposições dispostas uma ao lado da outra e carentes de um liame rigoroso de conectivos. A relação entre os acontecimentos descritos é relativamente maleável, destituída de uma organização explicativa rígida. As ações não obedecem a uma ordem hierárquica intensa e, portanto, o narrador aproveita, em vez de hierarquizar, as múltiplas ações projetadas pela situação tensa vivenciada pelas personagens. Em outras palavras, essa representação descontínua tende a reforçar as sensações experimentadas pelos seres ficcionais e a sugerir uma atmosfera de angústia e fragmentação intensas.

Por outro lado, conforme observa Silva (1981), o predomínio da hipotaxe em um texto, caracterizado pelas subordinações e uma organização sintática mais rígida, exprime "uma visão do mundo que acredita na potência da razão humana, capaz de relacionar os fatos entre si” (p.122). Desta maneira, as partes, representadas pelas orações, são subordinadas ao todo, ou seja, o texto, e essa organização se dá por meio da inteligência vinculada a uma “aplicação analítica e a busca de explicação" (Id., ibid., p.123).

\footnotetext{
${ }^{15}$ She wants to break down badly. She wants to fold up completely and have this all disappear. She dances in tight circles in the middle of the empty highway [...]. "Oh God! Oh God! Oh God!" she cries out. Nothing answers. She stops still. The hawk stops too and just stares at her with his blinking yellow eye, the black pupil cold as stone in the center. His beak is wide open, panting for air. She can see his pink wedge of a tongue. [...] The bird just blinks. His head snaps from side to side, bewildered.
} 
Se, por exemplo, na passagem acima, em vez de lermos "Seu bico está bem aberto, ofegante. Ela consegue enxergar a ponta rósea de uma língua", lêssemos algo como "Ela consegue enxergar a ponta rósea de uma língua porque o bico do pássaro está bem aberto, ofegante", o conetivo em destaque reforçaria na sentença a relação de hierarquia, pois passamos a ter duas orações dependentes, uma principal e a outra subordinada. Além disso, a conjunção porque indica uma tentativa por parte do enunciador de criar uma razão plausível para a personagem ter visualizado a língua do pássaro. Dessa maneira, a quase simultaneidade dos pequenos acontecimentos percebidos pela personagem em um momento de grande tensão plasmados na passagem original dá lugar, em nosso exemplo, a uma relação de causalidade: a oração subordinada apresenta a causa direta do que se declara na oração principal. $O$ enunciador, desse modo, mostraria de forma mais clara uma habilidade rigorosa de realizar operações lógicas a partir de dados aleatórios do universo ficcional.

Por essa mesma razão, se em vez das orações paratáticas “'Oh, Deus! Oh, Deus! Oh, Deus!' ela grita. Nada responde", tivéssemos uma única sentença como, por exemplo, ““Oh, Deus! Oh, Deus! Oh, Deus!' ela grita, porém, nada responde”, estaríamos diante de uma relação adversativa, em que a conjunção porém conferiria uma ênfase maior à quebra de expectativa. Desprovidas da conjunção, as frases apresentam relativa independência, pois se trata de dois enunciados mais ou menos equivalentes, que, justapostos, não expressam de modo tão agudo esse sentimento de frustração. A oração "Nada responde" apenas demarca o completo isolamento da personagem, sua imersão em uma esfera material, palpável e dolorosa — que evoca o universo árido de Esperando Godot, de Beckett (1982) — em que está ausente qualquer forma de transcendência de cunho espiritual, metafísico. Se Shepard, no entanto, tivesse usado um but antes dessa oração, poderíamos dizer que a oração dependente revelaria uma posição mais lamentável do sujeito, despertando o páthos no leitor em relação à situação angustiante vivenciada pela personagem.

O relativo "afrouxamento" da ordem hierárquica tradicionalmente imposta pelas coerções sintáticas mostra uma tendência dos processos paratáticos de promoverem a coexistência lateral entre os termos. Nesse sentido, o conceito de parataxe (em termos de apagamento de relações de subordinação e hierarquização) foi tomado posteriormente como uma metáfora de ordem política, fato que o fez transcender de vez o campo da sintaxe para inscrever-se em uma esfera muito mais ampla de discussão. Adorno, por exemplo, ao analisar a poesia de Hölderlin, considera os usos da parataxe como "desordens artísticas, que se esquivam à hierarquia lógica da sintaxe subordinativa", pois os elementos se conectam "de outro modo que no raciocínio" e evocam a música (1973, p.100). Já nas décadas finais do 
século XX, Hayden White publicou um texto no qual tratava da parataxe em termos de "rebelião artística" (1971, p.67) contra as estratégias hipotáticas de representar e organizar a experiência do real. Segundo White, o estilo paratático é "inerentemente democrático e igualitário em vez de aristocrático e elitista [como as formas hipotáticas]", pois a "consciência paratática" consiste em "uma linguagem de disjunções lineares" (p.69, grifos nossos) ${ }^{16}$ que evita organizar a realidade baseada em relações de subordinação e dominação. Contrariamente à noção, exposta acima por White, de que a parataxe favorece a linearidade, argumentamos que, em alguns casos, os processos paratáticos podem embotar as referências temporais e espaciais dos acontecimentos, tornando quase inviável a tarefa de determinar qual a ordem e o local em que as ações se deram.

Se, por exemplo, analisarmos as seguintes passagens do conto "Ouvir águas", de Noll, concluiremos que a ordem das pequenas orações é intercambiável, sem grandes alterações em termos de significado: "Pombos na praça. Um homem jogava bola, como se retirado num fundo de cenário. Imaginei fosse um domingo. [...] Uma lagartixa passava por entre pedras num canteiro. O PM rondava. E por trás de tudo um córrego vazava seu lamento" (2003a, p.94). Essa possibilidade de se ler trechos predominantemente paratáticos dos contos de Noll em uma ordem diversa da hierarquia unidirecional estabelecida pelas regras de escrita evoca as ideias de Jeanette Winterson expressas no prefácio de seu livro Oranges Are Not the Only Fruit (1985): "Pode-se ler Oranges em espirais [...]. Não vejo qual o propósito de se ler em linhas retas. Não pensamos e nem vivemos assim. Nossos processos mentais estão mais próximos de um labirinto do que de uma rodovia" (1991, p.xiii) ${ }^{17}$

Além de sugerir a possibilidade de se ler algumas passagens de seus microcontos em espirais ou em ordens diversas do tradicional sentido do esvaziamento horizontal do texto, a presença de processos mentais labirínticos em textos de Noll manifesta-se também em termos da incorporação recorrente de elementos narrativos incompletos. Esses elementos, inseridos no texto ficcional, tendem a gerar incertezas narrativas e a promover a sensação de instabilidade do próprio universo imaginário. Diante disto, analisamos a seguir alguns desses aspectos em vários trabalhos que compõem a trajetória do autor como romancista e contista.

\footnotetext{
${ }^{16}$ inherently democratic and egalitarian rather than aristocratic and elitist [...] paratactical consciousness: a language of linear disjunctions.

${ }^{17}$ You can read Oranges in spirals [...]. I don't see the point of reading in straight lines. We don't think like that and we don't live like that. Our mental processes are closer to a maze than a motorway
} 


\subsection{O universo instável das ficções de João Gilberto Noll}

Grande parte das personagens que povoam o universo imaginário das narrativas de João Gilberto Noll definem-se pela circulação e pela instabilidade, isto é, são seres ficcionais sempre em trânsito, mesmo que sem uma trajetória definida. De maneira semelhante ao que ocorre com muitas personagens das peças e contos de Sam Shepard, a ficção de Noll também projeta indivíduos em pleno processo de deslocamento por várias cidades do Brasil e do mundo, em busca de uma ilusão de liberdade oferecida pelas ruas, estradas e caminhos, pelo contato com espaços vastos a céu aberto (MAGALHÃES, 1993, p.17). Para as personagens de ambos os autores, os limites físicos impostos pelos ambientes familiares e de trabalho tendem a representar a clausura e a submetê-las a um regime de domesticidade massacrante. A circulação, a fuga, a errância e a perambulação, em contraste, ainda que não ofereçam soluções ao ser ficcional, representam o alívio momentâneo de uma existência inadequada ou, no caso de Shepard em particular, de uma rede de familiaridade à qual o sujeito não se sente em condições de se adaptar. Em se tratando de Noll, o deslocamento dos protagonistas tende a motivar a narração e projetar o universo ficcional. Nesse sentido, Klinger (2007) observa que:

Todos os romances de Noll aludem a lugares transitórios, cenários sem historicidade, cidades sem traços históricos, esvaziadas de progressão e de tempo. As viagens dos personagens, na verdade derivas e perambulações sem rumo, não estão dotadas de nenhuma função libertadora, edificante ou pedagógica; não oferecem ao personagem nenhuma formação, nenhuma Bildung, nenhum enriquecimento (p.57).

Como se observa, duas questões são ressaltadas na citação de Klinger: a primeira delas, já abordada no primeiro capítulo deste trabalho, diz respeito à percepção do universo ficcional de Noll, construído em parte de seus textos (cf. NOLL, 2003a, p.31, 42, 70, 321, 222, 322, 447) como um lócus indeterminado, carente de ancoragens estáveis em termos de referenciais palpáveis da realidade; a segunda consideração refere-se à falta de um padrão determinado de percurso narrativo envolvendo os deslocamentos espaçotemporais das personagens. Em vez de acumularem conhecimentos capazes de promover o "crescimento" das personagens como sujeitos, seja em termos de aprendizado ou mesmo de certa experiência reveladora ou libertadora, os "andarilhos" de Noll, pelo contrário, veem-se presas de uma 
trajetória de perdas e de esfacelamento psicológico e, algumas vezes, até mesmo corporal. Por essa razão, críticos como Santos (2005) reconhecem em narrativas de Noll uma tendência oposta ao Bildungsroman, isto é, a concretização de uma espécie de narrativa ou romance de "deformação" da personagem (p.18).

No conto "Alguma coisa urgentemente", o pai do protagonista, após perambulações indefinidas como provável guerrilheiro e vítima de tortura militar, reaparece ora sem um braço, ora sem dentes e afinal muito debilitado. Ao ser questionado pelo filho se sentia dor, responde que "já não sente nada" (1997b, p.687). A revelação do pai repercute para além da constatação da mera fragilidade fisiológica de seu corpo moribundo, isto é, como se, ao final de tantas errâncias, o eu tivesse uma percepção de si mesmo como um ser destituído de quaisquer rastros de sentimentos ou "lições" aprendidas com as experiências dolorosas passadas. De modo similar, o eu-protagonista do microconto "Erosão", de Mínimos, múltiplos, comuns, comenta de maneira autorreflexiva a dificuldade de produzir sentidos a partir de suas próprias experiências, uma vez que o "tom" de sua fala costuma "[ir] atropelando qualquer ponderação". Desse modo, além de não conseguir articular suas experiências e lembranças ao longo de um "fio condutor" sequencial, o protagonista "falha" em organizar as experiências vividas - "Quis me recompor desses fatos que não deixavam rastro, que não me esclareciam" - e, por não conseguir (ou não querer) ordená-los, opta por “[enfiá-los] todos na mala” (2003a, p.40, grifos nossos), isto é, sobrepondo-os de maneira não seletiva.

A narrativa de Noll e, em especial, os contos, conforme veremos, não costumam avançar de maneira convencional, isto é, no sentido, conforme postula Moisés (1973) a respeito do conto tradicional, do acúmulo progressivo de dados e consequente "elucidação do nervo central da história” (p.130). Em outras palavras, ao invés de conhecermos cada vez mais das personagens e do universo ficcional na medida em que avançamos na leitura, com frequência deixamos o texto de Noll com a impressão de sabermos cada vez menos a respeito dessas personagens. Essa "deficiência” epistemológica é empregada aqui no sentido de que não encontramos em textos do autor um sentido cumulativo de desenvolvimento dos seres ficcionais ou percebemos essas mesmas personagens como entidades de traços difusos, não integrados ou indeterminados, e, portanto, não passíveis de "conhecimento" na acepção histórica e linear tradicional.

Retomando a questão, abordada no Capítulo I, a respeito da ênfase na geração de interesse pelo conto tradicional, Franco (2006) observa que “o narrador-personagem [...] tradicional quase sempre escreve para narrar sua vida, que, normalmente, apresenta aos outros 
algum interesse especial, ou, ao menos, para - em esforço crispado - tentar entendê-la" (p.117). Ainda segundo Franco, em algumas narrativas contemporâneas, no entanto, o narrador é "desprovido de uma experiência fundamental que garanta o interesse de todos por sua narrativa: sua vida não é diferente da dos demais e, como todos, também ele não tem nada de especial para narrar" (p.118). Embora seja possível sustentar, no caso específico de Noll, que as errâncias em si já constituiriam tipos de experiências até certa medida diferentes das vivências dos demais, os narradores-protagonistas em Noll costumam vivenciá-las como eventos banais, esvaziados de qualquer "aventura" ou aprendizado. Por essa razão, o próprio narrador deixa transparecer uma sensação generalizada de que seus deslocamentos, bem como sua própria narrativa, não têm nada de especial e, portanto, decorrem de episódios monótonos dentro de uma existência tediosa e, em muitos aspectos, desinteressante.

Soma-se a isso o distanciamento entre os fatos narrados e o momento da narração, que é reduzido ou nulo, isto é, os eventos são, via de regra, narrados em tempo real ou imediatamente depois de ocorridos, não permitindo ao narrador analisar ou mesmo refletir minimamente sobre o papel ou a importância desses traços de experiência dentro de sua própria construção narrativa. Seidel (2001) acrescenta que na narrativa de Noll, tem-se a sensação de que o eu-protagonista vive "em um presente perpétuo, em um presente sem profundidade, sem definição e sem identidade segura” (p.129). Nesse sentido, o relato constitui-se com frequência a partir de dados em estado "bruto", dispostos de modo a criar-se a impressão de aparente não seleção e aproveitamento direto do vasto repertório de vivências cotidianas. Essa noção é reforçada por Otsuka (2001):

o encadeamento dos acontecimentos [em Rastros do verão e, devemos acrescentar, em narrativas de Noll, de maneira geral] não obedece à lógica da causalidade, princípio que rege a construção do enredo tradicional. Aqui os eventos sucedemse como que por acaso, acidentalmente, sem vínculos claros de significação entre eles. O relato organiza-se como sucessão de momentos descontínuos, em que cada instante corresponde a um presente sem passado (p.111).

Por esse motivo, a maioria dos textos de Noll estrutura-se de modo a não oferecer epifanias, pois, em vez do desvendamento do objeto pelo sujeito, percebemos que as experiências não comportam instantes reveladores e o "sentido" - em termos de encadeamento elucidativo - que essas mesmas vivências poderiam proporcionar, tende a se 
esgarçar e tornar-se opaco tanto para o leitor quanto para o próprio narrador, conforme atesta o eu-protagonista do microconto "Erosão" (2003a, p.40).

Retomando a analogia com o Bildungsroman sugerida acima por Klinger, Avelar (1999) também chama a atenção para aspecto semelhante nas narrativas de Noll:

\begin{abstract}
A arquitetura geral do texto de Noll - a deriva constante, o foco na primeira pessoa, a tentativa individual de dar sentido ao passado, a natureza temporária de todas as coisas suscita uma aproximação com o Bildungsroman, a não ser pelo fato de que não há qualquer Bildung, pois as personagens perderam a habilidade de aprender com a experiência ou, de modo similar, a experiência não pode mais ser sintetizada de maneira formativa a partir da consciência individual (p.193). ${ }^{18}$
\end{abstract}

Dessa maneira, por investir menos força na Bildung, isto é, na síntese formativa em termos de conhecimento das experiências individuais ou coletivas, as narrativas de Noll, de modo paradoxal, via de regra promovem um "afrouxamento" do relatório sequencial de ações, fatos e vivências para enfocar a própria linguagem. Esta costuma figurar como mais uma protagonista dos textos. Por esse motivo, em vez do narrar convencional - no sentido etimológico de "contar", "dar a saber" ou "fazer conhecer através do dizer" (cf. CASTRO, 2002, p.70) - Noll tende muitas vezes a desenvolver um discurso híbrido, isto é, uma prosa que incorpora elementos ditos poéticos como polissemias, ritmos e imagens simbólicas, com o intuito de promover o que o autor chama de "coagulação" do instante, uma espécie de celebração íntima do próprio “dom” da fala. Entretanto, como o autor faz questão de salientar, "a trama certamente comparece (do contrário a ficção seria apenas um jogo formal), mas ela vai se desenvolvendo a partir de uma compulsão estrutural que antecede a história ficcional". 19

Seja pela celebração íntima do instante, seja em virtude do destaque na primeira pessoa, conforme atesta Avelar (1999, p.193) acima, podemos afirmar que a ficção de Noll

\footnotetext{
${ }^{18}$ The general architecture of Noll's text - the constant drifting, the focus on the first person, the individual attempt to make sense of the past, the temporary nature of everything - invites an approximation with the Bildungsroman, except that there is never any Bildung, because characters have lost the ability to learn from experience or, which amounts to the same, experience can no longer be synthesized in a manner formative of an individual consciousness.

${ }^{19}$ NOLL, João Gilberto Noll. Estilo e somatização. In: X SEL - SEMINÁRIO DE ESTUDOS LITERÁRIOS, 2009, Caderno de Resumos. São José do Rio Preto - SP: UNESP - Universidade Estadual Paulista, Instituto de Biociências, Letras e Ciências Exatas, 2009, p.31.
} 
aciona um foco deliberado no eu não apenas como consciência individual, mas também como campo de forças corporais e, sobretudo, sexuais. Desde a primeira coletânea de histórias até o mais recente romance, observamos que sua ficção tende a trazer para o primeiro plano narrativo uma intensa carga libidinal investida no eu-protagonista.

De maneira geral, traços fortemente obscenos da sexualidade humana, que tendem a se opor à estética clássica e subverter os padrões do politicamente correto, costumam ser silenciados, aludidos de maneira indireta ou simplesmente figurar no rol do interdito na maior parte dos escritos convencionais.

Em Noll, entretanto, as pulsões sexuais do indivíduo não só são expostas em seus aspectos mais carnais (e abjetos), mas assumidos e vividos de maneira aberta pelos eus que em geral narram esses episódios libidinosos, fazendo uso abundante do registro oral e do palavreado de baixo calão. Nas palavras de Bosi (1994), essa característica da ficção de Noll deve-se ao fato de que "o essencial da escrita acompanha os movimentos dos corpos que se atraem ou repelem em um clima de delírio" e, dessa maneira, a prosa do autor gaúcho vai "riscando com estilete o desenho pesado da sexualidade do nosso urbanoide" (p.436).

As ocorrências desses traços "pesados", aos quais se refere Alfredo Bosi, vão desde os primeiros romances como Harmada - "Cheguei em casa, Jane não estava, me fechei no banheiro. Sentei na privada, comecei a brincar com o meu pau, prepúcio para cima, prepúcio para baixo" (1993, p.37) — a textos mais recentes, como Acenos e afagos: "Por aquele orifício chamado cu tinham passado caralhos alemães de todos os naipes e calibres. Fui enfiando devagarzinho o meu indicador" (2008, p.92).

Neste último romance, por exemplo, a libido, que engolfa todo o universo ficcional e aciona a própria narração, assume as mais diferentes orientações e fantasias sexuais. $\mathrm{O}$ eu alterna variadas formas de gratificação sexual, desde as mais comuns como heterossexualidade, bissexualidade e homossexualidade, até momentos de zoofilia, incesto, necrofilia, coprofagia, sadomasoquismo e fetichismos. Este último traço, por exemplo, motiva até a inserção narrativa de um implausível submarino alemão, na verdade uma sucata da Segunda Guerra Mundial, tripulada por marinheiros uniformizados. O próprio narrador atenta para o absurdo do episódio que ele mesmo narra ao exclamar, surpreso: "Navio no [rio] Guaíba? [...] Mas qual não foi meu espanto ao avistar no Guaíba o lombo de um submarino alemão!" (2008, p.19). E a partir daí, o protagonista, que busca "prazeres interditos na província” (2008, p.21), embarca literalmente em uma orgia subaquática com múltiplos parceiros desconhecidos. 
Em Berkeley em Bellagio, o protagonista, que narra as próprias experiências ora em primeira ora em terceira pessoa e, em muitos aspectos (nome, idade, profissão, nacionalidade etc.), confunde-se com o próprio autor, evoca episódios que também sugerem uma sexualidade bastante móvel e plástica. Durante essas passagens, o narrador vive experiências sexuais com parceiros de diferentes gêneros e tenta fundir, no mesmo ato, rituais carnais e religiosos:

Raro é esse ragazzo para quem ele olha agora e diz: sim, Deus baixou aqui, é vivo. [...] Era Deus que ele continha no seu peito arfante, não o Deus que não saía das igrejas, mas o Deus que pulsava atrás da calça apertada do ragazzo, o Deus que se aplumava e se punha rígido, colosso! [...] O Deus que foi levado pelo escritor porto-alegrense para trás de uma cortina malcheirosa pelo tempo, o Deus que ali se deixou ordenhar como um bovino e que ali se deixou beber não bem em vinho, mas em leite que o nosso senhor gaúcho engoliu aos poucos, na carestia da idade, lembrando-se da Primeira Comunhão, terço nas mãos, as de bem-aventurança - de joelhos olhou o ragazzo como se rezasse (2003c, p.30).

Como podemos notar, a ficção de Noll, com algumas exceções apontadas pelo estudo de Brayner (2006, p.90-100), encontra-se saturada de valores falocêntricos, conforme podemos atestar na seguinte passagem do mesmo romance:

Ela o masturbava sem avidez. Ele enfiava o dedo primeiro com suavidade pela vagina dela e encontrava lá no fundo um pênis em miniatura; quando chegava ali, a coisa já o esperava, em riste, e nela ele mexia como num pênis sem glande ou prepúcio, pura umidade que a promessa de seus dedos tinha o dom de excitar. Naquele ponto ocluso se banqueteavam, até que o seu próprio pau monstruosamente maior viesse a toda e entornasse o leite pelas coxas dela. Aliás, ele nunca conseguiu (nem procurou por certo) uma única informação sobre essa peça do corpo feminino [...] Seria um quisto provedor de benefícios sem conta, o pau feminino primevo, simétrico aos mamilos masculinos que tanto prazer de carícias poderia dar a alguns homens? (2003c, p.15).

O trecho transcrito acima assinala a superioridade tanto física quanto sexual (a posse de um pênis maior e mais "completo") do macho em relação à mulher, cuja genitália é descrita como incompleta, rudimentar, isto é, como uma versão primitiva e em "miniatura" do 
falo "perfeito". A escolha de termos como "peça", "coisa" e "quisto" para referir-se aos órgãos genitais femininos sugere uma atitude depreciativa em relação à mulher e uma evidente predileção do narrador por aspectos da anatomia masculina, capaz de garantir-lhe (por meio da imposição) a supremacia tanto sexual quanto hierárquica sobre o corpo e a psique femininos.

Longe de podermos equacionar esse dado às efetivas convicções pessoais do autor, podemos observar que mais do que uma tentativa de perpetuar a ordem simbólica patriarcal — questão à qual teremos oportunidade de retornar de modo mais pormenorizado no capítulo dedicado a Shepard - , importa salientar nesse momento que as narrativas de Noll engendram uma subjetividade intensa, calcada nos desejos egotistas de um eu exacerbado e no empreendimento do que um dos narradores de Noll define como uma "epopeia libidinal" (2008, p.48), que por estar atrelada via de regra ao masculino, tende a não incluir as perspectivas do "Outro", ${ }^{20}$ no caso, a mulher.

Vale frisar dois pontos importantes: em primeiro lugar, apesar de as afirmações de que valores falocêntricos e até mesmo misóginos são engendrados pelos sujeitos ficcionais de Noll, esses indivíduos não se identificam com os valores heteronormativos que embasam os comportamentos vinculados à noção tradicional de masculinidade. Em outras palavras, não se trata de seres ficcionais criados nos moldes do Homem arquetípico que associamos à hegemonia patriarcal heteronormativa (cf. BYERS, 1995, p.5-7). Pelo contrário, trata-se de um recorrente sujeito sexuado, cujo gênero, em sua porção anatômica genital, não determina necessariamente a sexualidade que esse mesmo indivíduo performatiza no cotidiano. Dessa maneira, os seres ficcionais masculinos de Noll, por meio da pluralidade de suas práticas e desejos sexuais, também submetem a noção cristalizada de masculidade a questionamentos e indeterminações. Nesse sentido, ao se permitirem relações bissexuais, homossexuais, homoafetivas e até uma "transmutação" (2008, p.102) de gênero, sexo e desejos no recente romance Acenos e afagos, esses indivíduos egotistas e falocêntricos incorrem, de modo paradoxal, em comportamentos rechaçados pela própria ordem simbólica patriarcal sob a forma de preconceitos como a homofobia e a misoginia.

\footnotetext{
${ }^{20}$ A categoria de "Outro" é empregada aqui conforme entendida por Simone de Beauvoir, que, a partir de Lévinas, argumenta que a ideia de "outridade", fundamental para o pensamento humano, não estava originalmente atrelada à divisão entre os gêneros. Essa dualidade, tão primordial quanto a própria consciência, está relacionada, entretanto, ao fato de a Humanidade ser masculina e definir as mulheres não em si mesmas, mas em relação ao homem. A partir desse estabelecimento do homem como o Sujeito, o feminino é reificado, relegado a uma posição secundária, estando fadado a ver o indivíduo masculino como o Absoluto e o Essencial (1989, p.xxii-xxiii).
} 
O segundo ponto que merece destaque está relacionado ao fato de que ao nos referirmos à centralidade do eu em textos de Noll, não podemos inferir a partir disso que se tratem de sujeitos autossuficientes, entronizados no centro do conhecimento (ou de algum lócus privilegiado) no sentido iluminista (cf. HALL, 1992, p.276). A ideia de centralidade expressa aqui tem mais uma conotação de dominância ou predomínio (no caso, do prisma subjetivo e subjetivante) do que necessariamente de sentido axial ou de ancoragem estável.

Otsuka (2001), em estudo do narrador de Rastros do verão, de Noll, tece considerações aplicáveis não apenas a esse romance em particular, mas a grande parte da produção do autor. Segundo o crítico, embora "o tom subjetivo" nos textos de Noll seja garantido pela escrita calcada nos mecanismos gramaticais da primeira pessoa, a ênfase sobre a vida interior ou sobre a investigação psicológica do eu, ao contrário do que se poderia esperar, sofre uma redução nos relatos do autor (p.103-104):

Tradicionalmente, as notações subjetivas da narração em primeira pessoa aparecem como sinais da dimensão interior, mas em Rastros [do verão, bem como em outras narrativas de Noll,] isso não acontece: os signos da subjetividade apontam somente para um vazio - o vazio deixado pela interioridade inacessível. Essa consciência narradora constitui certo tipo de sujeito que emerge num mundo em que as possibilidades de vida interior são bastante reduzidas (p.104).

Em outras palavras, as narrativas se dedicam mais a direcionar o olhar para objetos que o eu presencia e fenômenos externos nos quais se vê envolvido do que a fazer sondagens intimistas e confessionais de sua vida interior ou realizar exames de como essa mesma dimensão introspectiva sofreria o impacto psicológico evocado por esses mesmos objetos circundantes (Id., ibid., p.104).

Em termos gerais, a tese aqui defendida é a de que o narrador (sobretudo em primeira pessoa, mas também em terceira) presente em alguns contos contemporâneos, em especial os de orientação minimalista e pós-moderna, tem seu caráter falível, inafiançável e problemático exacerbado. Essa noção relaciona-se ao argumento de Franco (2006), que associa a objetiva impotência do indivíduo tanto de reconciliar as inseguranças da própria vida quanto de "narrar a totalidade ou o nexo dos acontecimentos" a uma espécie de "vertigem na narração", que dilacera gravemente a experiência subjetiva (p.123-125). Esse dilaceramento do euprotagonista decorre do recente processo de desestabilização do narrador como centro nocional, ao qual a tradição literária reservou um papel consolidado de organizador, 
articulador e, em muitos casos, intérprete dos dados narrativos. ${ }^{21}$ Tanto em Noll como em Shepard, essa desestabilização é mobilizada pelos procedimentos narrativos de indeterminação e fragmentação. Dessa maneira, lemos os narradores de Noll como sujeitos que, apesar de egotistas, definem-se mais pela instabilidade, pelo esvaziamento, pela errância e pela precariedade física e psíquica do próprio eu individual.

A consciência dessa precariedade é sugerida pelo próprio autor, que, em recente conferência, ${ }^{22}$ ao ler passagens dos romances Lorde e Acenos e afagos, e o conto "Tecido penumbroso", publicado na coletânea Mínimos, múltiplos, comuns, optou por vocalizar o discurso em primeira pessoa dos narradores por meio de um entonação grave, porém bastante enfraquecida e rascante como a de uma pessoa muito idosa ou com uma saúde muito debilitada, próxima à falência do próprio ser. A entonação conferida por Noll à vocalização dos relatos em primeira pessoa apresentou-se como marcadamente distinta da própria entonação real do artista durante a conferência. Acreditamos que a escolha entonacional realizada por Noll de modo deliberado durante as vocalizações dos textos sugere, a partir do plano fônico, sentidos de precariedade e de falência corpórea e psíquica, isto é, traços que identificamos tanto em termos de conteúdo quanto em nível formal nas narrativas do escritor gaúcho.

A partir desse breve levantamento de aspectos gerais do projeto estético de João Gilberto Noll, examinamos, a seguir, o caso específico do livro Mínimos, múltiplos, comuns no tocante às instabilidades e desestabilizações materializadas nos microcontos.

\subsubsection{Aspectos estruturais e traços indeterminados de Mínimos, múltiplos,} comuns

Ao agrupar os textos publicados originalmente na coluna Relâmpagos em formato livro, o editor Wagner Carelli optou por conferir aos textos de Noll uma dada posição dentro de uma complexa estrutura de seções, subseções e outros conjuntos. Com uma abertura

\footnotetext{
${ }^{21}$ Nesse sentido, Castro (2002) observa que "o narrador é concebido tradicionalmente como o princípio organizador da obra, nas mais diferentes modalidades de sua construção: seja em primeira pessoa, seja em terceira, seja através dos diferentes personagens narradores ou ainda através da refletorização. Como princípio, o narrador é o que dá a função das partes no todo que é a obra" (p.57, grifos nossos).

${ }^{22}$ NOLL, João Gilberto Noll. Estilo e somatização. Conferência proferida durante a abertura do X SEL SEMINÁRIO DE ESTUDOS LITERÁRIOS, 2009, São José do Rio Preto - SP: UNESP - Universidade Estadual Paulista, Instituto de Biociências, Letras e Ciências Exatas, 13 de outubro de 2009.
} 
inspirada no Gênesis e um final apocalíptico, pode-se dizer que a estrutura de Mínimos, múltiplos, comuns evoca, até certa medida, a organização cronológica do texto bíblico. Porém, mais do que tentar conferir a esses microcontos tão diversos o aspecto conceitual "monolítico" que encontramos em textos totalizantes como a Bíblia, segundo a perspectiva exegética judaico-cristã, a coletânea de Noll prima pela fragmentação.

Além disso, o livro de Noll difere da estrutura bíblica no sentido de que evita a linearidade evolutiva ao apontar, ao final do volume, para o princípio do eterno retorno (ewige Wiederkunft) de Nietzche (1976, p.223). Dessa maneira, em vez da visão religiosa do mundo como uma linha composta de uma gênese e um fim (ou morte), a partir do qual uma nova vida eterna se iniciaria, a noção filosófica de Nietzsche, partilhada por Noll, concebe o universo não como um processo envolvendo reencarnações, mas apenas o retorno dos seres a seus mesmos corpos físicos. Dessa maneira, o tempo é entendido não como linear, mas recorrente e cíclico, e, as personagens que povoam as histórias, variações ou réplicas de um único e recorrente protagonista (cf. TREECE, 1997, p.8).

Já mencionamos na seção anterior que Noll tende a não se ater ao sentido etimológico do narrar, mas que o autor muitas vezes suspende momentaneamente o relato de acontecimentos para buscar a "coroação" do instante por meio da verticalização do próprio eu. Se associarmos essa noção, desenvolvida em Mínimos, múltiplos, comuns mais do que nos romances, à ideia de frustração tanto da progressão narrativa quanto do conceito mais geral de linearidade em favor de ideais como circularidade, estaticidade e recorrência, acabamos reconhecendo nas micronarrativas de Noll traços comuns a uma definição fenomenológica de poesia lírica.

De modo geral, a poesia lírica dedica-se à exploração estética da linguagem do estado de ânimo, isto é, à exaltação do sentir mais íntimo do sujeito, mediante uma condição de recolhimento. Aguiar e Silva (1973) argumenta que o fazer lírico "enraíza-se na revelação e no aprofundamento do próprio eu" (p.227), e diferencia os gêneros da seguinte maneira:

Este aspecto fundamental da poesia lírica [ou seja, a sugestividade simbólica] está diretamente relacionado com o caráter estático desta forma natural da literatura, em oposição ao caráter dinâmico da narrativa e do drama. O fluir da temporalidade, em que se inserem as personagens e os acontecimentos romanescos, é alheio ao universo lírico: o poeta como que se imobiliza sobre uma ideia, uma emoção, uma sensação, etc., não se preocupando com o encadeamento causal ou cronológico destes estados de alma (Ibid., p.230). 
Entretanto, a captação desses estados de alma nunca tende à explicação dos sentimentos, nem ao esclarecimento de aspectos da existência. Pelo contrário, segundo Staiger (1975), “a linguagem lírica parece desprezar as conquistas do progresso lento em direção à clareza" (p.39). Desse modo, a poesia lírica prima pela carência de conexões lógicas, fundamentações e esclarecimentos quanto ao "quando", o "onde" e o "quem" do discurso poético (Id., ibid., p.46). Por essa razão, o esteta analisa que a poesia lírica pode iniciar-se a partir de qualquer ponto, inclusive por conjunções como "e", "pois", "mas" ou qualquer outra expressão "obscura", afinal, "em qualquer parte, no fluir de um dia descaracterizado, a existência transforma-se em música" (Id., ibid., p.47, grifos nossos). Os sentidos líricos, portanto, tendem a ser percebidos "muito indecisamente" uma vez que o lirismo costuma desestabilizar as propriedades conceituais da palavra. Além da linguagem, o próprio eu lírico também é submetido à diluição: “O poeta lírico [...] é 'brando'. 'Brando' no sentido de que os contornos do eu, da própria existência, não são firmemente delineados. [...] O sentimento de individualidade dissolve-se" (Id., ibid., p.66).

Encontramos em Noll esse investimento em favor do lírico, sobretudo no que diz respeito à exploração das profundezas do íntimo e a um arranjo mais emocional e menos intelectivo de sensações e impressões suscitadas pelos dados narrativos. Mas seja também pela aparente relutância em "fazer sentido", bem como pela plasticidade das imagens que perfazem o livro Mínimos, múltiplos, comuns, os textos reunidos nesta coletânea almejam inserir-se no domínio da poesia. Em frases como "tudo se aquietou, é noite, o mundo vive pra dentro, cegando-se ao sol do sonho", do texto "Tecido penumbroso" (2003a, p.29), verificamos que a prosa de Noll em certos momentos aproxima-se do lírico por instaurar combinações melódicas de palavras e imagens simbólicas, porém sem a preocupação de "quebrar" as linhas em versos e estrofes. Dadas as características poéticas de muitos dos textos de Mínimos, múltiplos, comuns, parece inevitável a vinculação de traços líricos e forma narrativa, cuja construção evoca os Pequenos poemas em prosa (1869), de Baudelaire.

Não podemos, entretanto, concluir, a partir disso, que os textos reunidos no livro possam ser considerados poemas em vez de narrativas uma vez que a incorporação de elementos poéticos e melódicos pela prosa é relativamente comum no âmbito literário. Eagleton, por exemplo, observa em recente estudo que "não há recurso considerado 'poético' que certa obra em prosa em algum lugar não explore" (2007, p.26). ${ }^{23}$ Desse modo, parece

\footnotetext{
${ }^{23}$ there is hardly a device thought of as "poetic" which some piece of prose somewhere does not exploit.
} 
mais acertado, conforme já mencionamos, falar de passagens das narrativas de Noll em termos de um discurso híbrido, que congraça elementos ditos poéticos. Contudo, a prosa é a força motriz que, em última instância, impulsiona e constitui os sujeitos que protagonizam as narrativas do autor.

Talvez seja por essa razão que a qualidade poética e quase musical da prosa de João Gilberto Noll tende a engolfar não apenas leitores, mas também críticos em uma complexa rede de linguagens e imagens emblemáticas. Dessa maneira, muitos textos críticos que se propõem a discutir e analisar a obra do autor gaúcho não raro incorporam a linguagem própria dos contos e romances e tendem a substituir a referencialidade do discursos acadêmico por construções abstratas.

A referência à característica emblemática da prosa de Noll não deve ser associada a símbolos ou estruturas necessariamente herméticos, mas aos procedimentos textuais empregados pelo escritor na composição de narrativas que tendem a desestabilizar as relações de causalidade natural e linearidade das sequências narrativas. Desde contos como "Alguma coisa urgentemente", da coletânea $O$ cego e a dançarina (1980), em que o protagonista tem apenas um contato intermitente com a figura paterna, a romances mais maduros como Acenos e afagos (2008), no qual uma epopeia libidinal é composta a partir de transas episódicas e fragmentações da sexualidade, podemos inferir que grande parte dessas narrativas constitui comentários, ora minimalistas ora excessivos, da descontinuidade das experiências e dos próprios relatos que tentam plasmá-las.

Como o próprio autor aponta na epígrafe deste capítulo, grande parte de sua escrita destaca-se pela indeterminação como "sensação mestra", isto é, um sentimento de incerteza que tende a materializar-se de variadas formas como, por exemplo, a recorrência de frases como "sei lá", "não sei” ou "não sabia” (cf. 2003a, p.53, 60, 81, 94, 190, 263, 376, 451 etc.), conferindo ao texto um sentido de dúvida metódica. Além disso, a contingência do universo ficcional de Noll projeta-se por meio de certa imprevisibilidade dos enredos, que costumam ser mais uma sobreposição de incidentes aleatórios do que o gradual desenrolar de um fio condutor responsável por determinar as fases que compõem uma hierarquia narrativa. Microcontos tais como "Na correnteza" (p.33), "Línguas" (p.41), "Ouvir águas" (p.94) buscam afigurar-se mais como uma coleção de encontros fortuitos dentro de uma ampla gama de possibilidades do que uma sucessão planejada de episódios regidos pelo "destino" ou outra força unificadora. E, por essa razão, os leitores têm dificuldade em prever o rumo da história uma vez que a dissociação de imagens e ideias, presente nesses contos pós-modernos, tende a obliterar os próprios conceitos totalizantes de "rumo" e "história". 
Embora a desestabilização das noções de linearidade e causalidade natural sempre tenha feito parte do repertório de procedimentos narrativos adotados pelos romances e contos de Noll, a coletânea Mínimos, múltiplos, comuns é a que mais se destaca, dentro da produção do autor, como um corpo de textos que, via de regra, tenta bloquear o processamento cognitivo das microestruturas narrativas em sentido convencional. Por essa razão, cabe detalhar, na seção seguinte, aspectos envolvidos no processamento cognitivo de textos narrativos em geral e, mais especificamente, como os microcontos de Noll oferecem exemplos atípicos de concatenação dos elementos do enredo.

\subsection{Processamento cognitivo de narrativas de João Gilberto Noll}

Para tratarmos do problema das indeterminações nos contos literários dos autores contemplados por nossa pesquisa, faz-se necessário um breve estudo de alguns aspectos implicados no processamento cognitivo do texto literário e, sobretudo, do bloqueio conforme notamos ao analisar o conto "Ninguém”, de João Gilberto Noll, no capítulo I — do estabelecimento de quadros de referência (frames) por parte do leitor durante a atividade de processamento dessas narrativas. Cabe salientar que essa proposta de abordagem de base cognitiva dos contos baseia-se no método exposto por Lohafer e Clarey (1989, 263-267).

A partir de estudos nas áreas de psicologia e inteligências artificiais, alguns críticos como Van Dijk (1979), buscam elucidar como o leitor (ou o ouvinte, ou o expectador) de fato compreende e armazena informações ou percepções do texto literário (em especial, artefatos de cunho narrativo), em vez de se concentrar na forma como o leitor "informado" (cf. EAGLETON, 1996, p.74) da teoria da recepção deveria consumir esse mesmo texto. De acordo com essas pesquisas, acredita-se que o leitor construa de modo gradativo uma representação semântica ou conceitual do texto na memória. Dessa maneira, a grande variedade de informações de caráter morfológico, sintático e semântico é "traduzida" ou transformada - por meio de sequências complexas de processos e em diversos níveis - em sentidos, que são representados de maneira cognitiva em termos de conceitos (VAN DIJK, 1977, p.145). As memórias, de curta e de longa duração, são imprescindíveis para a execução desses processos. A memória de curta duração, cuja capacidade é limitada, constitui a área em que aparentemente o fluxo de sensações, percepções e informações é analisado e interpretado de modo inicial. Essas operações são com frequência realizadas de maneira alinear e o 
resultado, isto é, os esquemas gerais derivados da nossa compreensão das proposições individuais de um texto, por exemplo, são armazenados na memória de longa duração. Quase sempre, os dados depositados aí não podem ser retomados pelo leitor de maneira integral, isto é, uma vez apreendido o significado conceitual das informações armazenadas pela memória de curta duração, não há a necessidade de se lembrar dos pormenores de frases e estruturas superficiais específicas. Aliás, esses detalhes estruturais pouco salientes costumam ser "esquecidos" pelo leitor (Id., ibid., p.146).

Segundo os estudos, acredita-se ainda que haja ao menos dois níveis de interpretação semântica do discurso literário. O primeiro deles diz respeito ao nível local, que "envolve a interpretação das sentenças e o estabelecimento de relações coerentes entre sucessivas sentenças" em um campo de ação microestrutural. O segundo nível é o global, responsável por "estabelecer o tema, assunto ou a essência de um texto ou da passagem de um texto", 24 isto é, de elaborar uma interpretação geral (e mais abstrata) a partir das macroestruturas semânticas. Algumas operações envolvidas nesse segundo nível de processamento incluem a "eliminação" de dados que o leitor julga irrelevantes para a interpretação do texto e a generalização de sequências inteiras de proposições a fim de se obter uma proposição ainda mais geral, ou o que Van Dijk qualifica como um superconceito - por exemplo, "casamento" em vez de "noiva", "noivo", "padre”, "alianças", "arremesso do buquê” etc. Dessa forma, torna-se possível processar de maneira cognitiva padrões ou quadros de referência típicos de determinada ação ou acontecimento delineados pela narrativa (Id., ibid., p.146-147).

Esse processamento cognitivo amplo das estruturas textuais depende das leituras e do conhecimento de mundo do leitor, isto é, de um volume imenso de dados armazenados e organizados em sua memória de longa duração. Essa base de dados de experiências, cuja configuração varia muito de pessoa para pessoa, permite identificar quadros de referência (proposições mínimas envolvidas em episódios recorrentes como viagens, separações, assassinatos etc.) detectáveis nas estruturas narrativizadas, possibilitando o reconhecimento, em nível local, de padrões de relações coerentes entre os elementos microestruturais. Desse modo, compreendemos um texto, em última instância, quando somos capazes de juntar os fatos projetados pelas proposições do texto em conjuntos consistentes (Id., ibid., p.148). Van Dijk explicita essa noção nos seguintes termos:

\footnotetext{
${ }^{24}$ it involves the interpretation of sentences and the establishment of coherence relations between successive sentences. [...] establish the theme, topic or gist of a text or a passage of a text.
} 
Para fins de compreensão discursiva, entretanto, é típica a exigência geral de que aos textos deve ser atribuída coerência. Isso quer dizer, entre outras coisas, que as respectivas sentenças de um texto deveriam ser conectadas (de modo semântico). Para obter isso na memória de curta duração, devemos presumir que uma sentença anterior, ou suas proposições subjacentes, ainda esteja disponível na área de armazenamento (o buffer) da memória de curta duração, de modo que elas possam ser relacionadas às proposições da sentença que está sendo de fato interpretada (Id., ibid., p.146). ${ }^{25}$

É nesse ponto que algumas narrativas pós-modernas como, por exemplo, os contos de Noll e Shepard provocam um "curto-circuito" nas operações típicas envolvidas no processamento cognitivo dos elementos textuais. Alguns desses textos frustram de maneira intencional as noções de coerência uma vez que, como vimos, trata-se de narrativas em que algumas passagens ou frases não apresentam relações sintáticas nem semânticas rigorosas. No conto "Línguas", publicado em Mínimos, múltiplos, comuns, detectamos uma ruptura com a noção de causalidade natural a partir das seguintes proposições "ontem pediu um copo d'água à filha. Ela lhe trouxe a foto de uma mulher meio esquiva" (NOLL, 2003a, p.41).

No que se refere ao conto "Ninguém", de Noll, o uso de orações paratáticas, o predomínio de imagens dissociadas e a falta de continuidade das proposições dificulta o estabelecimento de relações entre a frase ou estrutura processada em determinado momento pelo leitor com as sentenças e proposições anteriores e/ou subsequentes. Nesse texto, em particular, uma ação não leva de maneira lógica à outra e uma proposição não conta necessariamente com a disponibilidade de informações na área de armazenamento referente à proposição anterior. Os nexos de coerência e até mesmo de coesão entre as ideias e imagens são incompletos ou "corrompidos". Em virtude da omissão deliberada de detalhes das proposições, muitas vezes o leitor tem dificuldades, ou não é capaz de recuperar esses dados fragmentários.

Além das interpretações semânticas nos níveis local e global, durante a leitura, o leitor de modo geral tentará organizar as informações em blocos — submetendo esses elementos a novas generalizações, apagamentos, acréscimos, substituições etc. - e atribuir o que Van

\footnotetext{
25 Typical for discourse comprehension, however, is the general requirement that texts must be assigned coherence. This means, among other things, that the respective sentences of a text should be (semantically) connected. In order to do this in STM we must assume that a previous sentence, or rather its underlying propositions, are still available in the storage room (the "buffer") of STM, so that they can be related with the propositions of the actual sentence being interpreted.
} 
Dijk chama de superestruturas esquemáticas às "histórias" projetadas pela narrativa. ${ }^{26}$ Essas complexas operações envolvidas no processamento do discurso literário, que não se dão de modo linear nem definitivo, denotam certo grau de variação a depender dos diferentes arranjos cognitivos dos leitores e de quais tópicos e temas estes julgam mais relevantes (1979, p.149).

De maneira atípica, algumas formas de discursos literários como a poesia e algumas vertentes modernas em prosa não apresentam, segundo Van Dijk, uma macroestrutura semântica ou apenas um tipo muito fragmentário de macroestrutura. Isso ocorre quando os pormenores superficiais do texto, por incorrerem em violações categoriais ou carecerem de redundância ou informações contextuais, não são passíveis de "tradução" em termos de proposições ou quando as próprias proposições falham em se conectar entre si por meio tanto de relações condicionais explícitas quanto de informações recuperadas da memória. Esses fatores, que o teórico holandês associa à ambiguidade, podem bloquear as operações implicadas no processamento cognitivo ou mesmo resultar em um tipo de compreensão parcial, pois uma interpretação óbvia ou imediata não se encontra à disposição do leitor. É possível ainda a ocorrência de uma "completa incoerência cognitiva", forçando o leitor a se satisfazer com uma interpretação apenas parcial do tema ou da atmosfera do texto processado (Id., ibid., p. 149-158).

Associamos, portanto, esse conjunto de ocorrências atípicas que interferem nas operações envolvidas no processamento cognitivo não apenas à ambiguidade, mas também à noção de indeterminação narrativa. Com base nessas informações, devemos verificar como contos de João Gilberto Noll, por meio de construções paratáticas, elementos descontínuos e indeterminados, tendem a eclipsar noções de coerência textual explícita.

\subsection{Traços indeterminados e processos paratáticos em textos de Mínimos,} múltiplos, comuns

Durante a leitura de Mínimos, múltiplos, comuns, os leitores geralmente deparam-se com algum aspecto textual "malresolvido" como, por exemplo, a projeção de incompletudes

\footnotetext{
${ }^{26}$ A participação do editor Wagner Carelli na organização dos 338 textos de Noll que perfazem o volume Mínimos, múltiplos, comuns deve ter envolvido operações de processamento cognitivo como homogeneizações, ordenações, generalizações etc. dos materiais díspares oferecidos para publicação. $\mathrm{O}$ estabelecimento das superestruturas temáticas, conforme exposto acima, e esquemas de hipercontextos presentes na coleção reforça a hipótese de coautoria de Carelli.
} 
espaçotemporais ou a radical omissão de pormenores que poderiam enraizar o microepisódio narrado em um contexto de motivos e explicações definidas. Vale salientar, mais uma vez, que termos como "malresolvido" ou "incompleto", quando empregados em conjunção com esses contos pós-modernos, neste caso, não devem ser entendidos como enunciados de caráter valorativo, mas apenas como designações classificatórias. Nesse sentido, as noções de ficção "malresolvida" ou "incompleta" opõem-se à visão tradicionalista de que "a finalidade geral da ficção é produzir uma ilusão narrativa o mais completa possível" (FRIEDMAN, 1975, p.157, grifos nossos). ${ }^{27}$ Feita essa observação, passemos à leitura de um dos textos que incorpora elementos indeterminados e emblemáticos. Trata-se do conto "Sangue do Guaíba", reproduzido integralmente abaixo:

Aquele sangue nas mãos que eu devia lavar ali, no Guaíba. Se não, desconfiariam. Do quê, nem eu mesmo sabia. Lembro que, pouco antes, num lance gratuito, imaginara que se tivesse ficado em casa estaria em melhor situação. Foi só então que vi as mãos cobertas de sangue. Olhei o rio, tentando escapar da circunstância. Apesar do estado das águas, entrei até os joelhos. E agora só restava assobiar. A melodia imprecisa, o dia ameno, parecendo ileso. Pouco a pouco o assobio amortecia tudo. A noite logo mais me acolheria. Para que sonhar? (NOLL, 2003a, p.107).

$\mathrm{Na}$ transposição dos limites físicos da coluna de jornal para o formato livro, o presente texto foi incluído na seção "Rios", pertencente à série "Águas”, que, por sua vez, constitui parte do sistema "Os elementos". O enunciado extremamente breve do conto, composto de apenas noventa e três palavras, concentra-se em pequenos eventos que, dado o caráter minimalista e fragmentário das imagens, não fornecem a impressão de um acontecimento "completo" da experiência humana. De modo semelhante ao que veremos em "Tinnitus", de Shepard, o texto de Noll emprega um estilo paratático de composição: as proposições formam pequenos fragmentos da experiência, mas em vez de se concatenarem em um todo coerente, essas parcelas poéticas criam uma variedade de imagens sensoriais e extrassensoriais (perceptivas e conceituais) que de certa forma resistem ao escrutínio lógico do raciocínio.

\footnotetext{
${ }^{27}$ the general end of fiction is to produce as complete as a story-illusion as possible.
} 
Assim, por mais que se tente saber a razão pela qual o narrador tem as mãos cobertas de sangue, as "pistas" narrativas não ajudam a determinar o motivo desse fato.

A primeira frase contém uma proposição dotada de uma qualidade plástica que não é estranha aos trabalhos anteriores do autor (SEIDEL, 2001, p.128-130): “Aquele sangue nas mãos”. A frase não esclarece a quem pertencem as mãos nem tampouco o sangue. Tanto a imagem violenta quanto as elipses propositais de pronomes possessivos fazem a sentença soar ambígua. Essa dificuldade em estabelecer o sentido, no entanto, não é resolvida pela frase seguinte. Dessa maneira, não dispomos de elementos textuais para determinar se tanto o sangue quanto as mãos pertencem ao narrador ou a uma outra pessoa. Embora possamos presumir que as mãos pertençam ao eu-protagonista, não encontramos subsídios indicando a quem pertence o sangue. A utilização desses dados ambivalentes impede o processamento desse enredo como uma variação da antiga história do "bandido e mocinho", concretizada sob a forma de sequências de fuga e perseguição. Dessa maneira, o mesmo conjunto de proposições que, por um lado, codifica traços familiares (sangue nas mãos, sentimento de perseguição, fuga) já repetidos em uma infinidade de discursos, apresenta, por outro lado, traços "confusos" e indeterminados que dificultam o processamento cognitivo das macroestruturas narrativas e sabotam essa mesma possibilidade de concretização do enredo.

As questões propostas pelo texto assumem contornos ainda mais indefinidas quando constatamos que o próprio narrador — no caso, também protagonista — afirma não saber as razões pelas quais pressente que deve livrar-se do sangue. Sem avançar em questões referentes à identidade do sujeito, que serão abordadas em detalhes no terceiro capítulo e na conclusão deste trabalho, podemos verificar que o eu responsável pela narração em "Sangue do Guaíba" destaca-se também pela indeterminação. Contrariando os narradores convencionais em primeira pessoa, em geral, relatores de memórias do passado e dados da vida íntima, o eu de Noll não esclarece nem pontos básicos como sua aparência, sua idade ou ocupação. Essas drásticas reticências são bastante recorrentes nos textos do autor, conforme aponta o crítico Aquiles R. Brayner:

[Alguns dos narradores em primeira pessoa de Noll] não se apresentam por meio de um eu "coerente" ou "absoluto", cuja existência precede o ato da leitura. Eles resistem de maneira aberta à ação de serem enquadrados em uma categoria identificável ao omitirem detalhes circunstanciais sobre suas 
vidas como nomes próprios, posição social ou lembranças de suas experiências passadas $\left(2006\right.$, p.133) ${ }^{28}$

Apesar de muito condensado, esse microconto — ou hipotexto, de acordo com Marchezan (2006, p.233) — exibe um padrão tensivo básico, isto é, o eu em confronto com o Outro. Porém, quando partimos para o plano mais concreto da trama, torna-se difícil estabelecer um conjunto coerente de proposições. O narrador, por exemplo, afirma que precisa lavar as mãos no rio Guaíba para evitar que desconfiem, mas não contextualiza qual o caráter dessa ameaça. Como não é possível determinar a quem pertence o sangue nas mãos, não podemos afirmar com certeza que ele tenha, por exemplo, ferido ou mesmo matado alguém. O leitor tenta aplicar vários contextos à narrativa, recorrendo à vasta "biblioteca" de leituras armazenadas na memória de longa duração, mas essas tentativas de preenchimento das lacunas ou de "harmonização" das indeterminações resultam parciais ou incompletas.

Conforme prosseguimos a leitura, as lacunas semânticas permanecem inconclusivas, pois o princípio que organiza o texto não favorece explicações nem tampouco constitui uma sequência narrativa, capaz de relacionar e iluminar as passagens vagas. A frase seguinte, por exemplo, não se relaciona necessariamente com a situação aludida antes, concentrando-se em um momento anterior no qual o narrador parece esboçar um arrependimento por ter saído de casa. Mas não temos nenhum subsídio para determinar onde se encontra essa "casa", quais as relações familiares / sociais e as circunstâncias implicadas nesse espaço. A única referência espacial é o rio Guaíba, que serve menos de coordenada realista do que de lócus imaginário para a recriação poética do autor.

Além das expressões "então" e "agora", o narrador também não fornece muitas indicações quanto à temporalidade. Outras pistas incluem referências ao dia "ameno" pouco antes do anoitecer, mas, de maneira geral, o texto não especifica de maneira clara quando os acontecimentos narrados ocorreram. O universo ficcional construído pelo texto, bem como por outras narrativas de Noll, é formado a partir de uma perspectiva desistoricizada, na qual "a noção de processo é perdida, e a temporalidade apresenta-se fragmentada, como mera sucessão de diversos instantes independentes, desvinculados de um continuum temporal mais amplo" (OTSUKA, 2001, p.114).

\footnotetext{
${ }^{28}$ do not present themselves through a 'coherent' or 'absolute' self, whose existence precedes the act of reading. They openly resist being framed in an identifiable category by omitting circumstantial details about their lives such as proper names, social position or a recollection of their past experiences.
} 
A "precariedade" (em termos de sequencialidade causal e coordenadas temporais) do relato denuncia certa (simulação de) incapacidade por parte do narrador em dar sentido às imagens e experiências fragmentárias que compõem suas vivências. O crítico Francisco Caetano Lopes Júnior, no artigo “A questão pós-moderna vista da periferia: o caso João Gilberto Noll”, atribui essa proliferação de imagens vagas na ficção de Noll a uma certa qualidade midiático-televisiva da prosa do autor:

\begin{abstract}
A narrativa de Noll, desde os contos do primeiro livro, não estabelece um par e passo [sic] com a representação da realidade [...], mas deixa que o leitor veja o seu cotidiano explodir em imagens ininteligíveis (por vezes até para o próprio narrador que, perplexo, apenas junta palavras, discursos e no-los derrama aos olhos sem nenhuma cerimônia) (1991, p.599).
\end{abstract}

No caso de "Sangue do Guaíba", a narração não explicita, como ocorre em grande parte da narrativa tradicional, qual a relevância ou o significado dos objetos e acontecimentos que o cercam. Ao confrontar-se com "a circunstância" descaracterizada à qual alude no conto, o euprotagonista prefere "escapar" e contemplar as águas do rio a tentar entender o que está acontecendo. Aliás, o leitor, que em grande medida "depende" dos dados narrativos para processar de maneira cognitiva o texto, experimenta dificuldades em estabelecer sentidos para essa "circunstância" que o narrador tem em mente em virtude do caráter reticente do relato.

Otsuka (2001), ao analisar a narrativa Rastros do verão, de Noll, afirma que, de modo geral, o "olhar do narrador não intenta buscar sentidos profundos que desvendem os objetos que abarca. Tampouco o que é visto parece repercutir de alguma forma dentro do narrador, pois o Eu que narra é um homem oco, um Eu sem interioridade íntegra" (p.107). Esse procedimento difere não apenas da contística tradicional como também das convenções romanescas segundo as quais a perspectiva do narrador costuma acrescentar percepções sensoriais e extrassensoriais à pessoa ou objeto que é visto, bem como "lembranças afetivas e analogias metafóricas" (OTSUKA, 2001, p.106-107). Essa noção também se aplica a "Sangue do Guaíba", pois o narrador não fornece insights quanto à situação em processo e mostra uma aparente incapacidade de organizar suas percepções visando a um fechamento coerente, em termos da concatenação de um enredo convencional.

Os gestos finais são ainda mais emblemáticos: “Apesar do estado das águas, entrei até os joelhos. E agora só restava assobiar”. Esta passagem sugere indeterminação porque, além 
de não esclarecer qual a condição em que se encontram as águas — informação que facilitaria o estabelecimento de relações entre o ambiente e o estado emocional do protagonista tampouco contribui para a compreensão, em termos lógicos, da experiência que o narrador tenta comunicar.

A seguir, o protagonista descreve o "dia ameno" como tendo uma aparência de "ileso". Se se trata de mera aparência, podemos presumir que, embora o "dia" — ou, de maneira metonímica, os seres que entraram em contato com o narrador ao longo desse período de tempo - pareça "ileso", ele, na realidade, foi ferido. Mas isso ainda não esclarece o porquê de o narrador ter as mãos cobertas de sangue. Não podemos determinar se ele de fato matou alguém, tampouco podemos afirmar que esteja ferido, pois, o sangue pode não ser dele, e não há qualquer menção a outras possíveis feridas. Essas incongruências reforçam a noção de que os textos de Noll não se constroem em favor de encadeamentos lógicos e interpretações racionais.

Ao contrário das conotações negativas que a água adquire, por exemplo, em contos como "The Third Thing That Killed My Father Off" e "So Much Water So Close to Home", ambos publicados na coletânea What We Talk About When We Talk About Love (1981), de Raymond Carver (1989, 2001), a água no texto de Noll representa serenidade e evasão temporária das circunstâncias tensivas que o protagonista delineou de maneira vaga anteriormente. Essa situação extrema em que se vê envolvido, cuja compreensão totalizante escapa ao leitor, sugere certa vulnerabilidade psicológica do protagonista, pois este demonstra não estar seguro dos acontecimentos e dá sinais de uma aparente dificuldade de distinguir entre fatos e hipóteses imaginárias.

Essa aparente incapacidade organizacional dos fatos e sensações afigura-se como uma característica do sujeito desmemoriado, isto é, um indivíduo incapacitado de relacionar presente e passado em um continuum coerente. Conforme sugere Franco (2006), esses são indícios do fenômeno de fragmentação do eu, uma vez que "reconstruir a memória é, como se sabe, manter a identidade e, mais do que isso, o próprio sujeito. Narrar é [...] também um modo de resistir ao processo de liquidação das forças da subjetividade". Em se tratando dos narradores-protagonistas de Noll, a impossibilidade de reconstruir a memória, bem como de narrar (no sentido tradicional de elaborar conhecimento narrativo por meio da concatenação de experiências) representa um intenso processo de dilaceramento e fragmentação do próprio sujeito narrador. Nesse mesmo sentido, Otsuka (2001) argumenta que "o mundo representado aqui [em Rastros do verão e, devemos acrescentar, nas demais narrativas de Noll] é 
desprovido de sentido e o sujeito esvaziado já não é capaz de moldá-lo num todo coerente" (p.108).

Quando examinamos os demais microcontos da seção "Rios", à qual pertence "Sangue do Guaíba”, percebemos que a maior parte deles associa sensações de entorpecimento ou confusão mental do protagonista à proximidade das águas de rios e regatos. Textos como "Baluarte" (2003a, p.105) e "Arfante" (Ibid., p.108), por exemplo, tematizam dificuldades de recordar o passado e dúvidas quanto a que rumo tomar. Os outros textos elaboram essas incertezas em termos de confusão mental e dificuldade de se autorreconhecer: "Passo a mão nos meus traços: devem ser outros, não os reconheço!" (Ibid., p.103), exclama o protagonista de "Matias, o pintor". Em "Vertente", a dificuldade de se autorreconhecer termina por liquefazer o corpo da própria personagem: "Via que não era mais o mesmo que aprendera a reconhecer. Sentiu a virilha molhada. Notou que toda a sua massa se diluía pelos poros. $\mathrm{O}$ corpo, ah, se desdobrava em córrego" (Ibid., p.106).

Ao evocar imagens de aquosidade e fluidez associadas não apenas à água e ao rio, mas também ao sangue e, finalmente, ao sonho, o narrador de "Sangue do Guaíba" expõe sua própria instabilidade como consciência ou centro nocional e, por conseguinte, a fragilidade do relato que produz. As imagens aquosas, recorrentes em vários textos de Noll (cf. 2003a, p.9397), bem como a gestualidade elaborada do protagonista, aliadas às estratégias de omissão e indeterminação contribuem para projetar um universo ficcional instável, saturado de percepções de tal modo fragmentárias que não podem ser fundidas em uma visão totalizante. O próprio texto, caracterizado por traços instáveis e "aquosos" em diversos níveis, acaba bloqueando algumas operações cognitivas envolvidas nas atividades de processar de maneira lógica e racional as estruturas "incompletas" da narrativa.

Essas dominantes temáticas e formais regidas por indeterminações espaçotemporais podem ser associadas às formas "debilitadas" de "actorialização", "espacialização" e "temporalização", desenvolvidas por Calabrese (1999, p.175), que caracterizam diversos objetos culturais contemporâneos. Aplicando essas categorias a alguns textos de Mínimos, múltiplos, comuns, podemos afirmar que essas formas "problemáticas" de espacialização (em termos da formulação de dados espaciais de modo parcial ou descaracterizado) e de temporalização (no tocante à incapacidade de totalizar dados temporais relacionados à fixação temporal das experiências) devem-se a um colapso geral da instância da actorialização, isto é, do processo de debilitação psíquica e física do sujeito ficcional responsável pelas percepções que dão corpo à narrativa. 
Embora essas dominantes temáticas e formais não possam ser estendidas de maneira universal à totalidade de textos da coletânea Mínimos, múltiplos, comuns, parte significativa desses artefatos literários, conforme já mencionamos em outra parte (cf. SOBREIRA, 2007a, 2007b), mobilizam traços indeterminados e fragmentários. Alguns exemplos dessas dominantes incluem textos como "Húmus" - no qual o sujeito ficcional desenvolve uma espécie de complexo de perseguição em relação a algo que nem ele próprio é capaz de determinar, pois vivencia a "falta de uma âncora plausível" no real (NOLL, 2003a, p.62) - e "Folia no limbo", cuja "história" é composta pelas impressões confusas de um sujeito imerso em uma situação inexplicável, que parece fundir vida real e performance artística (Id., ibid., p.79). Desse modo, podemos concluir que a exemplo de "Fulminante", cujo enredo consiste no gradativo desenraizamento de um sujeito de qualquer contato com a realidade palpável (Id., ibid., p.84), a coletânea de Noll conta ainda com vários outros textos marcados por indefinições do sujeito e fortes indeterminações espaçotemporais (cf. Id., ibid., p.43, 47, 50, $216,221,222,293,322$ etc.).

Parte significativa dos contos publicados em Great Dream of Heaven, de Sam Shepard, também incorporam traços indeterminados, episódios lacunares e processos paratáticos semelhantes aos detectados nos microcontos de Noll. A predominância desses elementos contribui para ressaltar, conforme veremos no capítulo seguinte, a ideia de fragmentação tanto dos sujeitos quanto das narrativas engendradas por esses seres ficcionais. 


\title{
Capítulo III
}

\section{IDENTIDADES E PERSPECTIVAS FRAGMENTADAS EM SAM SHEPARD}

\begin{abstract}
Em vez da ideia de 'personagem inteira', com motivos lógicos por trás de seu comportamento, na qual o ator mergulha, ele deve se considerar como um todo fragmentado com cacos e pedaços de personagem soltos em torno de um tema central. Em outras palavras, mais em termos de uma construção a partir de colagem ou como improvisações do jazz. ${ }^{1}$
\end{abstract}

Sam Shepard, 1980

\begin{abstract}
vivemos ao menos uma vida dupla nos vários compartimentos da nossa sociedade inevitavelmente fragmentada. Precisamos ter consciência de que somos de maneira fundamental até mais fragmentados do que isso; em vez de nos apegarmos a essa miragem específica do 'sujeito centrado' e da identidade pessoal unificada, seria melhor enfrentarmos de modo honesto o fato da fragmentação em uma escala global [... $]^{2}$
\end{abstract}

Fredric Jameson, 1986

Indeterminações e fragmentações em vários níveis e sentidos estão implicadas de maneira profunda em grande parte da prosa contemporânea (cf. SIMON, 2007, p.136; CALABRESE, 1999, p.57, 104). Ambos os processos nunca foram de todo estranhos à arte do conto, mas são nos desenvolvimentos mais recentes, em especial nas diretrizes minimalistas e em certas vertentes pós-modernas do gênero, que indeterminações e fragmentações alcançam relativa predominância.

Partes dos capítulos anteriores propuseram-se a descrever e analisar a problemática do processamento cognitivo de elementos não seletivos e traços indeterminados presentes em

\footnotetext{
${ }^{1}$ Instead of the idea of a 'whole character' with logical motives behind his behavior which the actor submerges himself into, he should consider itself a fractured whole with bits and pieces of character flying off the central theme. In other words, more in terms of collage construction or jazz improvisations (2006, p.61-62).

${ }^{2}$ live at least a double life in the various compartments of our unavoidably fragmented society. We need to be aware that we are even more fundamentally fragmented than that; rather than clinging to this particular mirage of the 'centered subject' and the unified personal identity, we would do better to confront honestly the fact of fragmentation on a global scale [...] (1986, p.66-67).
} 
narrativas breves dos autores em pauta. Cabe agora abordar alguns pontos de vista teóricos sobre a fragmentação da personagem, do universo ficcional, do foco narrativo, do texto em si e do próprio narrador e sua relação com o contexto ficcional.

De maneira geral, essa "estética do fragmento", conforme propõe Calabrese (1999), consiste em um "derramamento" de formas e conteúdos estilhaçados, que procede "desviando o centro e a ordem do discurso" (p.102). ${ }^{3}$ Ainda segundo o autor,

O fragmento como material criativo responde assim a uma exigência formal e de conteúdo. Formal: expressar o caótico, o casual, o ritmo, o intervalo da escrita. De conteúdo: evitar a ordem das conexões, afastar 'o monstro da totalidade' (Ibid., p.102). ${ }^{4}$

De maneira semelhante ao que ocorre no caso das indeterminações, as fragmentações podem materializar-se de diferentes modos no fazer literário. As duas epígrafes atestam a diversidade de formulações possíveis desse expediente. $\mathrm{O}$ dramaturgo e escritor norteamericano Sam Shepard, por exemplo, faz referência na primeira epígrafe à fragmentação da ideia de personagem "inteira", representada como um todo centrado e contínuo, em favor de uma colagem de elementos fragmentários, fluidos e improvisados. O crítico Ross Wetzscheon (2006) nota que "as personagens de Shepard em geral parecem imotivadas, implausíveis e inconsistentes à primeira vista — não porque não sejam verdadeiras, mas porque confundimos 'verdadeiro' com as convenções do realismo psicológico" e, nesse sentido, "raramente dizemos a respeito de uma personagem de Shepard: "é dessa maneira que fulano geralmente $a g e$ ', mas quase sempre dizemos: 'é desse jeito que eu às vezes me sinto'" (p.4, grifos nossos). ${ }^{5}$

Assim, os seres ficcionais em diversas peças e contos do autor em geral diferem de si mesmos tanto física quanto psicologicamente. Em outras palavras, a lógica de composição que rege essas personagens quase sempre prevê uma relativa falta de coerência e estabilidade

\footnotetext{
${ }^{3}$ derramarse eludiendo el centro o el orden del discurso.

${ }^{4}$ El fragmento como material creativo responde así a una exigencia formal y de contenido. Formal: expresar lo caótico, lo casual, el ritmo, el intervalo de la escritura. De contenido: evitar el orden de las conexiones, alejar 'el monstruo de la totalidad'.

${ }^{5}$ Shepard's characters often seem unmotivated, implausible, and inconsistent at first - not because they are untrue to life but because we confuse 'true to life' with the conventions of psychological realism. [...] We rarely say of a Shepard character, 'that's just the way so-and-so often acts,' but we always say, 'that's exactly how I sometimes feel'.
} 
dos seres ficcionais projetados pelo texto. Essa fragmentação deliberada da ideia de personagem como um ente "integral" - cujo comportamento e personalidade, embora sujeitos a alterações súbitas, busca manter uma consistência psicológica interna compromete as convenções realistas em sua acepção tradicional. Shepard, no entanto, encoraja os intérpretes de seus seres ficcionais a transgredirem esses limites. Em entrevista a Matthew Roudané, o autor declara que a criação de personagens coerentes - nos quais o leitor / expectador acredita como se fossem reais — não tem de ser a única nem a melhor das muitas possibilidades disponíveis ao artista (2002, p.74).

Além do tipo de fragmentação psicológica sugerida por Shepard na primeira epígrafe, os seres ficcionais são suscetíveis a outras possibilidades de ruptura. A crítica Roberta Rubenstein, por exemplo, em "Fragmented Bodies / Selves / Narratives: Margaret Drabble's Postmodern Turn" (1994), menciona tipos de fratura mais concretos como os infligidos de maneira violenta contra a integridade física das personagens. Essas possibilidades incluem amputações, fraturas, mutilações e outras agressões que comprometem não apenas a estrutura corporal das personagens, mas também ameaçam desintegrar a unidade simbólica do sujeito. Rubenstein destaca, sobretudo, os textos recentes de Margaret Drabble, cujas personagens sofrem fragmentações em vários níveis, aprofundando as disjunções tanto em nível temático quanto estrutural das narrativas. Em The Gates of Ivory, por exemplo, a protagonista conclui: "Não há consistência em mim. Não há cola. Não há grude. Eu não tenho coesão. Eu não faço sentido. Eu sou um vácuo. Eu sou fragmentos. Eu sou pedaços” (1992, p.105). ${ }^{6}$ Os textos da autora inglesa tendem a incorporar a estética da fragmentação pelo viés de imagens de decapitações, desmembramentos, e outras mutilações corporais, em virtude de acidentes, doenças e desastres sofridos pelas personagens, como metáforas da crescente visão pessimista da autora em relação à vida contemporânea (RUBENSTEIN, 1994, p.136).

No caso dos autores em pauta, podemos mencionar o conto "Alguma coisa urgentemente", de João Gilberto Noll, em que as brutais desuniões entre familiares e o estado de esfacelamento do país provocados pelos abusos da ditadura militar são inscritos no corpo da personagem do pai, que perde um braço e grande parte dos dentes durante sessões de tortura infligidas pelo regime. Essas fragmentações físicas da figura paterna ocasionam

\footnotetext{
${ }^{6}$ There is no consistency in me. No glue. No paste. I have no cohesion. I make no sense. I am a vacuum. I am fragments. I am morsels.
} 
graves rupturas de ordem social e emocional na vida do filho adolescente, que é forçado a interromper sua educação e prostituir-se para sobreviver (1997b, p.686).

Imagens de corpos fragmentados, em sentido literal, tanto de humanos como de animais saturam os textos de Sam Shepard. Neles, animais são castrados, destroncados, mutilados, atropelados, desencourados etc. Essas imagens violentas em geral não refletem apenas a antiga tensão entre cidade e campo, mas indiciam o processo de obliteração da dimensão natural, antes tão presente no oeste americano, da memória das grandes metrópoles pós-modernas.

Os corpos das personagens humanas, por sua vez, também servem de lócus para agressões e despedaçamentos em Shepard: um filho que usa uma prótese de madeira em lugar da perna amputada quase escalpela o pai vivo ao raspar-lhe a cabeça na peça Buried Child. Essas cenas de brutalidade mostram uma família americana disfuncional em pleno processo de desintegração e projetam "uma visão obscura da América agrária, em que a terra, e mesmo o clima 'catastrófico', parecem envenenados pelos habitantes humanos" (CLUM, 2002, p.180). ${ }^{7}$ Em Curse of the Starving Class, Beth, uma esposa aspirante a atriz tem a cabeça quase partida pelo marido violento. Nesse caso, o traumatismo cranioencefálico da personagem, conforme veremos adiante, provoca "fraturas" em sua articulação linguística, levando-a a romper com as formações discursivas que definem os papéis convencionais dos sexos (DeROSE, 1992, p.126-129; McDONOUGH, 2002, p.158). McGuee (1993), por exemplo, refere-se à personagem como tendo uma "psique "partida"" (p.104). ${ }^{8}$

Esses exemplos não esgotam as possibilidades de fragmentação dos seres ficcionais, que não se restrigem apenas ao sentido literal, mas podem incluir formas de "fratura" da personagem em um nível mais figurativo, entre as quais a castração simbólica é uma das imagens mais recorrentes em Shepard. A perda da identidade centrada como resultado de rupturas das instituições mediadoras e das experiências da alteridade material como um conjunto de discursos e culturas fragmentadas também constitui um tema recorrente nos contos do autor. Isso nos leva à segunda epígrafe do presente capítulo. Nela, Jameson desenvolve formulações preliminares sobre a perda da ilusão da identidade pessoal unificada em um contexto de rupturas e deslocamentos, aos quais o teórico voltará em Postmodernism,

\footnotetext{
${ }^{7}$ a dark vision of agrarian America in which the land, even the 'catastrophic' weather, seem poisoned by the human inhabitants.

8 'broken' psyche.
} 
or the Cultural Logic of Late Capitalism (1992) para examinar o esmaecimento do afeto e do estilo único como efeito colateral da perda do "ego" centrado burguês encarregado da expressão. Retomaremos essas questões de maneira mais detida ao tratarmos da fragmentação do sujeito pós-moderno nos contos "Coalinga 1/2 Way" e "Tinnitus", de Sam Shepard.

Esses deslocamentos e rupturas tendem a afetar a própria tessitura narrativa do texto, que incorporam elementos díspares e construções paratáticas, que são responsáveis pela divisão das sequências narrativas em pequenas parcelas carentes de totalização. Segundo Currie (1987):

\begin{abstract}
Os elementos constitutivos do texto pós-moderno raramente integram-se de uma maneira temática [...]; descontinuidades da narrativa e disjunções de personalidade não podem ser superadas - do modo como podem no caso do Modernismo canônico, por mais que a personagem ou a obra pareçam embaralhadas ou desestruturadas à primeira vista — por meio do apelo à lógica de uma metalinguagem 'simbólica' unificadora, ao discurso estável dominante, à hierarquia estabelecida ou à consistência do eu centrado (p.65). ${ }^{9}$
\end{abstract}

O alcance dos expedientes de fragmentação pode chegar ao livro per se e à própria página como suportes materiais para a produção de sentidos. Em "Tinnitus", de Shepard, bem como em contos de outros autores contemporâneos como Raymond Carver, Jesse Ball, entre outros, o texto é disposto em blocos, com espaços em branco que marcam as "quebras" de maneira visual na mancha tipográfica da página impressa. Exceto pelas fotografias que, em menor escala, ilustram Motel Chronicles, de Shepard (1982), nenhuma dessas formas de ruptura da uniformidade das unidades de composição do texto se compara à intercalação de páginas completamente negras e fotografias em preto e branco (Figs. 3, 4 e 5) que compõem a coletânea de contos Mínimos, múltiplos, comuns, de Noll. No livro, as folhas negras instauram interrupções do tipo fade in / fade out na noção de continuidade textual, além de demarcarem as zonas limítrofes entre os complexos sistemas e subsistemas de narrativas mínimas. A linguagem não verbal das fotografias, ideadas pela designer Vera Rosenthal, que ilustram cada um dos conjuntos de textos, por sua vez, estabelecem um interessante

\footnotetext{
${ }^{9}$ the constituent elements of the postmodern text seldom integrate thematically [...]; discontinuities of narrative and disjunctions of personality cannot be overcome - as they often can with canonical Modernism, however scrambled or unstructured character or text may first appear - by an appeal to the logic of a unifying 'symbolic' metalanguage, a dominant stable discourse, settled hierarchy or the consistency of a core self.
} 
contraponto em relação à linguagem verbal das ficções de Noll. Com seus brilhos prateados, ângulos desfocados, iluminações ambíguas e enquadramentos insólitos, essas ilustrações (imagens visuais) reforçam a fragmentação de imagens, perspectivas e demais elementos que compõem o universo imaginário das micronarrativas (imagens mentais) da coletânea.

Os territórios ficcionais ou "zonas", no sentido proposto por McHale (1987, p.44-45), projetados pelas narrativas pós-modernas são em geral campos de força nos quais tanto imagens, objetos, seres, bem como coordenadas espaçotemporais tendem à fragmentação. Alguns contos de Shepard, por exemplo, constituem episódios minimalistas, incompletos e alineares, isto é, fragmentos de uma vasta base de dados de experiências, cuja totalidade nunca é dada nem tampouco recuperada. Gilman (2005) observa que as paisagens dos textos do autor são formadas por

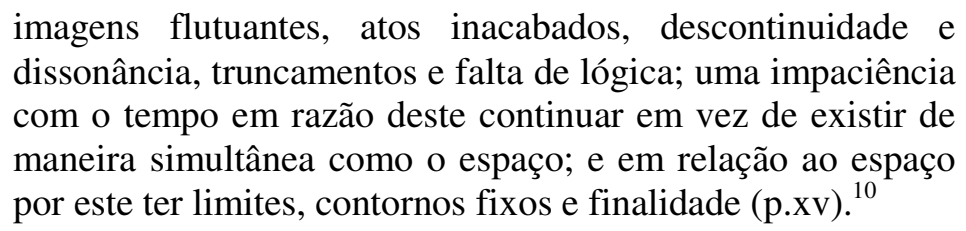

Embora nenhum dos contos de Great Dream of Heaven viole o continuum espaçotemporal de modo tão violento quanto a peça $A$ Lie of the Mind, em que os seres ficcionais atravessam a enorme distância entre a Califórnia e Montana em questão de segundos, podemos afirmar que alguns dos contos da coletânea de Shepard tendem a fragmentar esses referenciais. Como vimos, a personagem do pai em "Berlim Wall Piece" tem dificuldades em lembrar-se não só dos acontecimentos importantes que marcaram os anos oitenta mas também do próprio fato de ter vivido durante esse período (2002a, p.19-20). Em "Tinnitus", como veremos, o narrador omite vinte e dois anos da vida de uma personagem crucial para a trama (2002a, p.115). Essas passagens ficcionalizam a percepção da temporalidade como uma experiência descontínua, marcada por lacunas e fraturas. As personagens de Shepard também vivenciam experiências fragmentárias em termos de espacialidade, como no conto "Blinking Eye". O texto promove a fusão em um mesmo espaço emocional de topoi próprios a dimensões distintas como o mundo dos vivos, o mundo

\footnotetext{
${ }^{10}$ floating images, unfinished acts, discontinuity and dissonance, abruptnesses and illogicalities; an impatience with time for proceeding instead of existing all at once, like space; and with space for having limits, fixed contours and finality.
} 
dos mortos e o espaço mítico do oeste selvagem, representado por uma ave ferida (2002a, p.24-31)

Em uma das histórias (“A Frightening Seizure”) de Great Dream of Heaven, por exemplo, os filhos assistem assustados ao pai esmagar com o punho cerrado um ovo na mesa do café da manhã da família poucas horas antes de abandoná-los. Esse ato agressivo de fratura da casca que protege o embrião sugere uma ruptura mais profunda no frágil equilíbrio que sustenta a família projetada pelo texto (Ibid., p.109-111).

Seja pelo viés de temas como a ruptura da família nuclear ou o estilhaçamento espaçotemporal de memórias e experiências, seja em termos de fraturas físicas e psíquicas do sujeito ou de aspectos formais disjuntivos do próprio texto, a diversidade de fragmentações que identificamos em textos de Shepard, bem como nos de outros autores, sugerem a participação desses objetos culturais no próprio "espírito do tempo", conforme definido por Calabrese (1999), cuja orientação favorece a "perda da totalidade" (p.105). ${ }^{11}$ Esse relativo "ocaso da integridade", representado pelas poéticas da fragmentação no contexto contemporâneo, não apenas estimula a autonomia e o prazer do fragmentário, mas também promove a "anulação da memória sistêmica e contextual" (Id., ibid., p.104). ${ }^{12}$ Assim, o "espírito do tempo", segundo Calabrese, refere-se às fragmentações como possibilidades mais lúcidas, no atual contexto, em relação às ilusões cristalizadas por esquemas totalizantes:

[A recusa à integridade, cujo resultado é a emergência da 'estética do fragmento',] é também uma possível explicação (dentre as muitas) para a decadência dos grandes sistemas ideológicos 'fortes'. Não se trata apenas de uma decadência de modelos frente à modernidade (ou à pós-modernidade). $\mathrm{O}$ fato é que o detalhamento dos sistemas ou sua fragmentação tornam-se autônomos, com valores próprios e fazem com que se "percam de vista" os grandes quadros de referência geral" (p.105)..$^{13}$

\footnotetext{
${ }_{12}^{11}$ pérdida de la totalidad.

12 anulación de la memoria sistémica y contextual.

${ }^{13}$ es también una posible explicación (entre muchas) de la decadencia de los grandes sistemas ideológicos 'fuertes'. No se trata sólo de una decadencia de modelos frente a la modernidad (o postmodernidad). El hecho es que el detalle de los sistemas o su fragmentación se hacen autónomos, con valorizaciones propias y hacen literalmente 'perder de vista' los grandes cuadros de referencia general.
} 
Feito esse levantamento dos variados modos de fragmentações e descontinuidades detectáveis em produções artísticas de Sam Shepard, buscamos relacionar, na seção seguinte, algumas dessas dominantes temáticas e formais recorrentes no trabalho do autor ao contexto mais específico do livro Great Dream of Heaven.

\subsection{Considerações sobre a coletânea Great Dream of Heaven}

Dentre os quatro volumes de textos predominantemente em prosa que Sam Shepard tem publicado ao menos uma vez a cada década, Great Dream of Heaven, a mais recente coletânea de contos do autor, destaca-se pelo número expressivo de resenhas em geral positivas tanto nos Estados Unidos como em outros países (ATHERTON, 2002, p.1; BALDARO, 2002, p.81-82; BROOKS, 2002, p.26; KAKUTANI, 2002, p.7; REAL, 2002, p.E4; TARQUINIO, 2002, p.2; ZELLAR, 2002, p.20; ATHEY, 2003, p.227-228; CARVALHO, 2003, p.7; MALIN, 2003, p.145; VOGELIUS, 2003, p.1; THEISS, 2004, p.28). Nesse livro de ficções em prosa, o autor consolida-se como um contador de histórias (JAMES, 2002, p.30), em oposição aos papéis de memorialista ou autobiógrafo que o escritor exerceu nas coletâneas anteriores. Apesar da mudança sensível na postura do autor nesse livro, algumas das preocupações - ou "obsessões" - temáticas e estéticas que têm distinguido o trabalho de Shepard dentro e fora dos palcos ainda dão a tônica da maior parte das ficções coligidas no volume.

Os elementos que integram os universos ficcionais dos contos de Great Dream of Heaven não diferem de modo fundamental dos temas recorrentes nas produções teatrais de Shepard. Estão presentes os dramas familiares e, em última instância, humanos, como, por exemplo, os relacionamentos conflituosos entre pais e filhos, as dissonâncias entre casais, a solidão do ser humano, bem como questões sociais e culturais como a ascendência dos valores relacionados à sociedade de consumo, que, de certo modo, deprecia o valor simbólico da terra e das pessoas, a nostalgia em relação a um tipo de visão estereotipada do velho oeste americano, entre outros (COHN, 1988, p.1118-1119; SHEWEY, 1997, p.109; KAKUTANI, 2002, p.7). Esse estereótipo da "verdadeira" América relaciona-se, como observou William Demastes, ao "mito da América como sendo a terra da abundância e fiadora do sucesso 
pessoal para todos". ${ }^{14}$ Ainda segundo o autor, o trabalho de Shepard, sobretudo no âmbito teatral, tem contribuído para expor o estado de deterioração desse ideal (1987, p.234).

Os contos reunidos na coleção Great Dream of Heaven mostram não apenas a preocupação do autor com a perda do sonho americano em termos materiais, mas também o impacto dessa deterioração na psique dos sujeitos ficcionais. Em "Foreigners", um dos textos da coletânea, o protagonista do conto experimenta uma sensação de nostalgia e de mal-estar em decorrência das transformações sofridas pelo velho oeste, um território selvagem conhecido por seus cânions e desertos, mas que foi "tragado" pela ânsia empreendedorística das incorporadoras imobiliárias. O progresso e a suburbanização do espaço ocasionaram a substituição das paisagens originais por auto-estradas, motéis, redes de restaurantes especializados em fast-food, cassinos e condomínios. Esse avanço da chamada América pósmoderna, como aponta DeRose, contribuiu para tornar obsoletos os estilos de vida das famílias rurais dessas regiões com uma rapidez vertiginosa (1992, p.94). Dessa forma, o conto de Shepard mobiliza uma série de imagens que sugerem a perda de contato da figura romântica do homem natural com a natureza selvagem e a transformação deste sujeito em um eu deslocado, em crise com sua identidade e carente de referências sólidas de localização e de identificação.

A perda de elos consistentes com a terra no sentido histórico tradicional também motiva, em vários textos de Great Dream of Heaven, a desagregação dos vínculos sociais e familiares, levando sucessivas gerações, sobretudo indivíduos do sexo masculino, a desenvolverem comportamentos antissociais e a buscarem total isolamento. No conto "Coalinga $1 / 2$ Way" o protagonista troca de mulher repetidas vezes em uma tentativa de aliviar as sensações de deslocamento e inadequação que sente e cujas razões desconhece. E, apesar de jurar a si mesmo que jamais cometeria os erros de seu próprio pai, acaba, de maneira semelhante, abandonando a família e consolidando o vínculo com uma tradição de comportamentos abusivos cometidos por seus antepassados.

Ao contrário do que essas noções de hereditariedade e influência do meio possam sugerir, grande parte dos contos de Shepard "falham" em engendrar nexos consistentes de causa e consequência, que poderiam revelar uma lógica determinista e, portanto, naturalista ou realista, responsável pelos comportamentos desses seres ficcionais. Os textos instalam e

\footnotetext{
${ }^{14}$ The myth of America being the land of plenty and the guarantor of personal success for all [...].
} 
subvertem a noção não apenas de determinismo social, mas também as próprias convenções do realismo por meio da justaposição de personagens e situações realistas e de elementos absurdos, personagens caricatas e ambiguidades. Para Wetzsteon (2008), a predileção do autor por criar textos elípticos e fragmentários justifica-se da seguinte maneira:

Como muitos artistas contemporâneos, [Shepard] tem abandonado as convenções que garantem coerência - meios tradicionais de caracterização, narrativa, diálogo, estrutura e assim por diante - e tem tentado criar [uma obra] na qual estados emocionais, psicológicos ou espirituais são apresentados diretamente ao público [...]. Como o crítico Michael Smith certa vez escreveu a respeito do trabalho de Shepard: 'É como na vida real. Não dá para dizer o que está acontecendo' (p.4). ${ }^{15}$

Desde peças como True West e Simpatico - que promovem trocas de identidades entre personagens e a exploração de facetas contraditórias do sujeito - bem como The Unseen Hand (1970) - que funde em uma mesma cena dois foras da lei de filme Western, uma criatura bizarra vinda do espaço sideral e um animador de torcidas (PROCTOR, 1988, p.35-40) - a produção artística de Shepard distingue-se por uma mistura "estranha" de elementos que confundem o expectador (ou o leitor) e tornam o universo ficcional instável e muitas vezes indeterminado (cf. DEMASTES, 1987, p.234-235; DeROSE, 1992, p.94). Essa suspensão provisória das relações de causalidade pode ser observada em contos como "Tinnitus", em que as ações do protagonista carecem de explicações; "A Frightening Seizure", no qual duas crianças (e o leitor) não compreendem os comportamentos "sem sentido" do pai projetado pela história; e "An Unfair Question", no qual um homem, sem nenhuma razão aparente a não ser um surto de violência aleatório, mantém uma mulher desconhecida sob a mira de uma arma de fogo (SHEPARD, 2002a, p.97,109,112).

Muito da "bizarrice" de algumas passagens dos contos de Shepard são garantidas por sua recusa em reescrever várias versões do mesmo texto até chegar a um resultado mais "apurado". Ao contrário de grande parte dos contistas reconhecidamente em prática nos Estados Unidos, o autor, que afirma se inspirar em produtos culturais distintos como o rock-

\footnotetext{
${ }^{15}$ Like so many contemporary artists, he has abandoned the conventions of coherence - traditional means of characterization, narrative, dialogue, structure, and so on - and has attempted to create a [...] in which emotional, psychological, or spiritual states are presented directly to the audience [...]. As critic Michael Smith once wrote of Shepard's work: 'It's like real life. You can't tell what's going on'.
} 
' $n$ '-roll, o teatro de Beckett, as imagens pop e "pinturas em ação" de Jackson Pollock (SHEWEY, 1997, p.7,110), prefere absorver o "gotejamento" espontâneo de ideias e o fluxo não seletivo de imagens a reelaborar de maneira mais "racional" esses materiais. Nesse sentido, Brooks (2002) explica que "a escrita de Shepard dá a impressão de ser [um conjunto de] rascunhos, trabalhos apressados, acidentes felizes" (p.26). ${ }^{16}$ Dessa maneira, o trabalho de Shepard aproxima-se da dominante pós-moderna ao incorporar ao tecido narrativo o fluxo de imagens e ideias "acidentais" hauridas tanto da alta cultura (Pollock, Beckett) quanto da chamada cultura de massa (rock, filmes B e televisão). Esse aproveitamento sem relevo de elementos de caráter erudito e popular, conforme observa Jameson, oblitera a noção de "permanência de um espaço de experiência autêntico em contraste com o ambiente circundante de cultura comercial" (2006, p.88). Assim, Shepard, que "pensa mais em termos de mitos populares do que eruditos" (COHN, 1988, p.1119), ${ }^{17}$ colabora com seus textos cujo contexto de produção tende a seguir mais um "derramamento de sentimentos" do que uma "análise racional teórica" herdada de "formas culturais ou intelectuais" (WETZSTEON, 2006, p.6) ${ }^{18}$ — para embotar essas distinções e problematizar os aparatos críticos convencionais.

Alguns dos aspectos recorrentes no teatro de Shepard, tais como as relações abusivas entre familiares e o lamento pela perda do contato com a dimensão "espiritual" do oeste selvagem, recebem outros direcionamentos nas pequenas histórias de Great Dream of Heaven: em vez das personagens teatrais multifacetadas, cujas complexas vivências íntimas e segredos do passado, ainda que nunca resolvidos, são iluminadas diante do expectador por meio de diálogos e monólogos, nos contos, entretanto, as personagens conservam um aspecto inescrutável e o leitor quase nunca dispõe nem de tempo nem de subsídios textuais, conforme esperado, para examiná-las a fundo dada a efemeridade da forma e a relativa indeterminação em termos de contexto.

Há uma mudança substancial de cenários em relação às peças, que, embora possam de maneira geral encenar paisagens externas, costumam restringir-se a espaços fechados como quartos de hotéis (Geography of a Horse Dreamer, La Turista), motéis à beira da rodovia (Fool For Love), trailers (The Late Henry Moss), e ambientes domésticos como salas de jantar (Action), quartos (A Lie of the Mind), cozinhas (True West, Curse of the Starving

\footnotetext{
${ }^{16}$ Shepard's writing reads like first drafts, rush jobs, happy accidents.

${ }^{17}$ thinks in terms of popular rather than erudite myths.

${ }^{18}$ spontaneous outpouring of feeling [...] theoretical rationale [...] cultural or intellectual forms.
} 
Class), varandas (Buried Child, A Lie of the Mind) e banheiros (Fool For Love). Nos contos, além desses locais, as histórias projetam espaços vastos, que lembram os cenários dos contos de João Gilberto Noll, como longas rodovias, campos abertos, céus infinitos, entre outros. Embora cada um dos contos do volume possua suas próprias particularidades, podemos analisar que a expansão dos "cenários" ameniza parte da energia destrutiva dos duelos violentos protagonizados pelas personagens confinadas nos pequenos espaços de peças como Fool For Love e True West. Porém, ao mesmo tempo que as amplas paisagens do oeste possibilitam a fuga e a sensação de liberdade, elas ameaçam envolver o sujeito em dúvidas e em desorientação, conforme indicam alguns dos textos da coletânea.

Além dessas diferenças detectáveis entre o drama e o conto de Shepard, há pontos de convergência entre os dois gêneros. Alguns dos textos de Great Dream of Heaven, como "Betty's Cats", apresentam uma pequena situação a partir apenas de diálogos, como em um esquete teatral. "Convulsion", por exemplo, evoca a estrutura do solilóquio ao projetar uma personagem que, em primeira pessoa, expressa seus pensamentos e sentimentos em relação à amada, como se os declamasse diante de uma plateia. O texto "It Wasn't Proust" é uma história marcada pelos mecanismos tradicionais do conto como a condensação e o suspense. Porém, do ponto de vista formal, as notações entre parênteses quanto a detalhes do ambiente e emoções das personagens lembram, até certa medida, as rubricas teatrais. Por outro lado, indicações como "um lago negro profundo; um dos dezenas de milhares que existem naquela região solitária. Este em particular é um lago artificial, cujo formato é o de um diamante perfeito" (2002a, p.76), ${ }^{19}$ sugerem uma dimensão e mobilidade de "cenário" que extrapolam os limites físicos do "palco" e remetem ao roteiro cinematográfico.

Como artista de cinema e sobretudo de teatro, Shepard possui, segundo Brooks (2002), um “ouvido aguçado para diálogos", ${ }^{20}$ capaz de registrar em poucos fragmentos de conversa uma experiência dramática intensa (p.26). Desse modo, várias das histórias no livro valem-se quase que totalmente de diálogos, como é o caso de "The Stout of Heart", "It Wasn't Proust" e "Living the Sign". Nesse caso, "Betty's Cats" consiste no exemplo mais radical por simular o apagamento da figura do narrador por meio do registro exclusivo das falas das personagens, sem qualquer tipo de intervenção direta de um comentarista entre os

\footnotetext{
${ }^{19}[. .$.$] a deep black lake; one of tens of thousands in that lonely region. This one's a man-made lake in a perfect$ diamond shape.

${ }^{20}$ sharp ear for dialogue.
} 
diálogos. A presença do articulador, contudo, está implícita na própria seleção das falas e da cena.

Todavia, a remoção do narrador em virtude de uma suposta proximidade maior entre leitor e cena deve-se menos a uma tentativa de criar uma ilusão de realidade - como se o leitor pudesse "ver" e "ouvir" por si só os acontecimentos sem a "intrusão" de um articulador - do que a uma certa curiosidade do autor em testar os próprios limites da forma conto e, se possível, transgredi-los. Como vimos, alguns setores do conto pós-moderno primam por uma relativa recusa das "receitas" tradicionais do gênero e pela busca de alternativas em termos de efeitos sobre o leitor. No caso de Shepard, conforme argumenta Wetzsteon (2006), a recusa dá-se tanto em relação aos "métodos convencionais de narração - acontecimentos sequenciais, continuidade espaçotemporal, distinções nítidas entre realidade e fantasia" - quanto no tocante a "fórmulas [em especial, as concernentes à representação realista] segundo as quais a experiência é em geral organizada" (p.4). ${ }^{21}$

No tocante à coletânea de contos de Shepard, podemos afirmar que, assim como ocorrem com os microcontos de Noll, essas pequenas narrativas a todo o momento pressupõem e minam as convenções do gênero, ora aproximando-se da forma tradicional, ora "explodindo" o molde e, como vimos, incorporando elementos de outros gêneros e estilos.

Após essa abordagem centrada no contexto específico da prosa de ficção de Sam Shepard, passamos, no próximo seguimento, a uma focalização mais ampla do projeto estético do autor, que contribuirá para a compreensão de imagens e temas engendrados pelas narrativas de Great Dream of Heaven. Nessa seção, distinguimos alguns aspectos dominantes em suas principais produções, sobretudo nos textos dramáticos, e discutimos esses elementos com base na fortuna crítica a respeito do escritor e dramaturgo.

\subsection{O universo imaginário de Sam Shepard}

Como referimos anteriormente, a produção textual de Sam Shepard em diversos meios e gêneros se distingue pelo tratamento substancial de temas ligados ao contexto

\footnotetext{
${ }^{21}$ conventional methods of narration - sequential events, continuity of time and space, clear-cut distinctions between realism and fantasy [...] formulas in which experience is usually packaged.
} 
sociocultural do oeste americano em especial, mas ao invés de focalizar os ideais tanto de nobreza - encarnados pela Família Americana tradicional - como de heroísmo (vinculados à figura mítica do caubói), seus textos concentram-se no momento da obsolescência desses estilos de vida, que coincide com o advento da modernidade e consolida-se com o fenômeno da pós-modernidade (DeROSE, 1992, p.3).

Em vez das visões baseadas em utopias econômicas e religiosas do velho oeste como a última fronteira da terra prometida em que as férteis propriedades rurais figurariam como novos jardins do Éden, Shepard nos fornece perspectivas desses territórios como locais de perdas e tragédias. Na peça Buried Child (1978), por exemplo, a improdutividade do solo e a decadência do casarão patriarcal compõem o espaço emocional habitado por uma família devastada supostamente por um antigo caso de incesto e infanticídio (2005, p.61-132). Os seres ficcionais que habitam esse território - antes dominado, no imaginário nacional, pela figura mítica do caubói - são sujeitos problemáticos, ora em busca de suas raízes e novos "mitos", que podem ser figuras emblemáticas como o soldado americano ou os astros do cinema e do rock, ora em rota de fuga desses mesmos vínculos, cuja materialização é o repúdio à fama (Angel City; Cowboy Mouth), ou o rompimento com os vínculos sociais (“Coalinga 1 12 Way”, Paris, Texas; True West).

Essa substituição ocasiona o aparecimento de sujeitos desajustados e violentos, frutos de um legado familiar de fracassos e decepções. Em True West (1980), por exemplo, uma discórdia entre um roteirista de Hollywood e seu irmão marginal revela os laços hereditários de ambos com um pai ausente, alcoólatra, que é incapaz de se adequar aos papéis sociais de pai e marido (2005, p.1-59). Na peça A Lie of the Mind (1985), por exemplo, Shepard oferece uma visão bastante disfórica do soldado americano, epítome do herói nacional, em uma cena em que a mãe conta à filha que seu pai militar não morreu em combate: "ele não era nenhum herói. Foi atropelado por um caminhão. Bêbado como uma cobra no meio da rodovia" $\left(1986\right.$, p.34). ${ }^{22}$

As inedaquações entre casais é, de maneira geral, um tema comum em incontáveis textos dramáticos do teatro americano, como parte da visão tradicional da separação dos papéis socieconômicos entre os gêneros. Coltrane (1996) refere-se a esse fator como a chamada visão das "esferas separadas", sendo que o campo de ação do homem reside nos

\footnotetext{
${ }^{22}$ He was no hero. Got hit by a truck. Drunk as a snake out in the middle of the highway.
} 
papéis de provedor e protetor, enquanto a tarefa da mulher é a de ser "boa" esposa e mãe (p.25). Mas, no caso específico de Shepard, essas dissonâncias são mais irreconciliáveis, pois o autor mostra que a fusão, mesmo que momentânea, entre os elementos masculino e feminino é marcada por extrema instabilidade (MURPHY, 2002, p.136). Em A Lie of the Mind, por exemplo, o casal Baylor e Meg quase nunca consegue reconciliar suas diferenças. A certa altura da peça, Meg desabafa com o marido: "Talvez seja mesmo verdade que nós somos tão diferentes que nunca seremos capazes de comunicar certas coisas um para o outro" $(1986, \text { p.76) })^{23}$

A peça Curse of the Starving Class (1978), nessa mesma linha de raciocínio, encena a disputa entre o casal Weston e Ella Tate pelo direito de se desfazer da arruinada propriedade rural da família. Contudo, as cenas de brigas e discussões entre marido e mulher, recorrentes no universo de Shepard, quase não são vistas nesta peça, pois o autor optou por sugerir as dificuldades de relacionamento dos dois por meio de desencontros: quando um chega, o outro já saiu, isto é, as duas personagens raramente dividem o espaço ficcional do palco. Quando afinal se encontram, o confronto dos Tate é violento, conforme sugere um episódio rememorado por Ella ao final da peça: uma águia sobrevoa o telhado do celeiro da família e apanha um gato em suas garras. Os dois animais iniciam uma luta feroz em pleno ar. Vencidos pelo cansaço e pelos ferimentos, os dois precipitam-se sobre a terra, completamente destruídos (2005, p.199-200).

O violento antagonismo contido nessa imagem sugere, de maneira aguda, a impossibilidade de compreensão mútua e coexistência pacífica entre o feminino e o masculino nos dramas familiares e em alguns contos recentes de Shepard, como "A Frightening Seizure", "The Door to Women" e "All the Trees Are Naked", do volume Great Dream of Heaven, em que "a impossível lacuna entre homens e mulheres" nunca se fecha (2002a, p.141). ${ }^{24}$

Desse modo, o autor tende a desestabilizar os ideais da família nuclear americana, cristalizados pela cultura popular, sobretudo no que se refere ao papel dos pais de famílias (family men) americanos, que segundo Coltrane, eram idealizados durante grande parte da história americana como dotados "de razão e autoridade moral superior", faculdades que os

\footnotetext{
${ }^{23}$ Maybe it really is true that we're so different that we'll never be able to get certain things across to each other.

${ }^{24}$ the impossible gap between men and women.
} 
habilitavam a atuar como "supervisores ideais do desenvolvimento espiritual de seus filhos" $\left(1996\right.$, p.29). ${ }^{25} \mathrm{Na}$ ficção de Shepard, que, em geral, desenrola-se na atualidade, em que as tradições rurais já estão mais que obsoletas, esses ideais vinculados à superioridade da figura paterna são eclipsados por meio da inscrição de homens agressivos, quase sempre trabalhadores rurais brancos (rednecks) desiludidos com as promessas do sonho americano e incapazes de orientar ou servir de modelo de conduta para seus filhos.

Essas personagens masculinas sofrem do que McDonough classificou como "patologia patriarcal", isto é, uma tendência hereditária a recorrer ao consumo de bebida alcoólica ou ao refúgio no deserto $^{26}$ como forma de esconder ou negar as próprias vulnerabilidades e de transformar o corpo feminino em um campo de forças simbólico para o extravasamento, em geral, de maneira abusiva, dessas frustrações e inseguranças (2002, p.154-164). Por essa razão, muitas das peças familiares do autor focalizam desuniões e reencontros violentos entre casais, irmãos, pais e filhos, cujos resultados destrutivos evocam aspectos das tragédias gregas (CLUM, 2002, p.174; ADLER, 2002, p.115).

Como já mencionado, as peças e contos de Shepard ficcionalizam a passagem desse legado de brutalidade masculina através das gerações mais jovens, que reproduzem os mesmos comportamentos abusivos. Mas essas visões problemáticas da herança patriarcal ecoam as complexas relações do próprio autor com sua figura paterna (BIGSBY, 2002, p.24) e as marcas deixadas pelos abusos físicos e psicológicos sofridos por Shepard durante a infância. Esse histórico de agressões, revelados pelo artista em diversos textos (SHEPARD, 1982, p.31,55-56), em entrevistas (SHEWEY, 1997, p.18; ROUDANÉ, 2002, p.71) e em especial no documentário This So-called Disaster (EUA, 2004), tornam difícil não identificar, na fase madura de seu teatro e em alguns de seus contos, componentes de um mecanismo de reparação, ${ }^{27}$ por meio de processos criativos, dos traumas vivenciados.

\footnotetext{
${ }^{25}$ reason and moral authority [...] ideal overseers of their children's spiritual development.

${ }^{26}$ A figura recorrente, em Shepard, do pai alcoólatra exilado no deserto é inspirada em dados biográficos do autor. Segundo ele, seu pai também "gastava com Bourbon todo o dinheiro que [o artista] lhe dava para comprar comida. Enchia a geladeira de garrafas". Shepard acrescenta que seu pai morava sozinho no deserto, pois não "se dava bem com as pessoas" (1982, p.56-57).

${ }^{27}$ O termo "reparação" é usado aqui no sentido a ele atribuído por Melanie Klein. Conforme sintetiza Olsen (2004), "Klein utilizou o termo reparação para indicar o empenho da criança em reparar a imagem parental, cuja representação interna o indivíduo sente que foi prejudicada em virtude de demonstrações de agressividade. A psicanalista introduziu o termo em 1929, tendo utilizado restituição e restauração em sentido similar, embora menos preciso. Ademais, Klein associou a reparação à criatividade de maneira geral, proporcionando, por meio disso, um novo ângulo para a compreensão da estética, sobretudo no que se refere ao processo criativo" (p.34). De acordo com Klein (1975), em todo ser humano há uma constante interação entre o amor e o ódio, de modo
} 
Embora sejam pouco recorrentes, é possível encontrar na produção artística de Shepard algumas raras alternativas mais positivas para as subjetividades masculinas. A peça The Late Henry Moss (2000), por exemplo, trata do vínculo hereditário de violência e culpa entre os irmãos Earl e Ray em relação ao patriarca da família. Há, no entanto, uma personagem que se destaca nesse contexto trágico: o fiel mexicano Esteban. Ele foi capaz de superar seus próprios problemas com o alcoolismo e acabou se tornando o único amigo e cuidador do ingrato Henry Moss. Esteban também consegue articular seus sentimentos de uma maneira mais produtiva do que as demais personagens, que interpretam suas lágrimas e cuidados como sinais de fraqueza, e apenas se comportam de modo destrutivo. Essa alternativa, digamos, mais "benéfica" para a subjetividade masculina proposta por Shepard acaba passando, no entanto, por traços convencionalmente associados ao universo feminino: além de externalizar as emoções, Esteban em geral aguarda de modo paciente o retorno do Sr. Moss dos bares e, para curar-lhe a ressaca, prepara-lhe uma tijela de sopa quente quase todas as noites (2002b, p.29,85). O comportamento de Esteban contraria os estereótipos da identidade masculina, que, segundo Coltrane, "tendem a suprimir e desvalorizar os componentes gentis e vulneráveis de suas psiques em um esforço inconsciente de manter uma percepção firme de masculinidade" $\left(1996\right.$, p.6). ${ }^{28}$ Dessa forma, conforme argumenta Clum (2002), o "remédio" para essa patologia patriarcal em Shepard envolveria a constituição de um homem mais civilizado, ou "feminizado", em oposição ao espírito anárquico do macho dominante (p.175).

Shepard não se atém, no entanto, a essa lógica binária entre o homem viril e o homem feminizado - ou woman-man, como propõe a personagem Beth da peça A Lie of the Mind (1986, p.58) - e sugere, no conto "Remedy Man”, do livro Great Dream of Heaven, uma alternativa produtiva de subjetividade masculina, ao mesmo tempo capaz de articular sentimentos de afeição e de atuar em um campo de ação tradicionalmente másculo. O texto codifica duas histórias em uma única narrativa: a luta de um domador de cavalos chamado E.V. para amansar um animal bravo, que evoca, em um plano mais abstrato, os conflitos do protagonista infantil com Mason, seu pai autoritário e brutal. Ao longo do texto, o garoto manifesta predileção pela figura gentil do domador E.V., pois a presença desse remedy man é

que o trabalho de reparação é "um elemento fundamental no amor e em todos os relacionamentos humanos" (p.97). A agressividade e o ódio podem, nesse sentido, ser utilizados em formas construtivas ("sublimadas") como reparação de relações afetivas internamente representadas.

${ }^{28}$ tend to suppress and devalue the soft and vulnerable parts of their psyches in an unconscious effort to maintain a firm sense of masculinity. 
como "uma mão cálida pousada suavemente sobre o [seu] peito" (2002a, p.5), ao contrário de seu pai, que é um “inútil”, incapaz de consertar o caos (MALIN, 2003, p.145). Desse modo, o narrador conclui que "deve haver homens crescidos [como E.V.] neste mundo que realmente tiram uma centelha da vida e que, de alguma forma, conseguem se esquivar do buraco negro no qual [s]eu pai caiu" (Ibid., p.4-5). ${ }^{29}$ Embora o texto não associe qualquer elemento em particular a essa imagem do buraco negro, que em The Late Henry Moss assume a forma de um "túnel negro" (2002b, p.63), parece óbvio que gravitam em torno de seu vórtice traços como alcoolismo, negligência e abusos, isto é, aspectos que ameaçam desintegrar a instituição da Família Americana, e que, como vimos, compõem a chamada patologia patriarcal recorrente nos textos de Shepard.

Essa recorrência de personagens masculinas abusivas em textos do autor, no entanto, tem despertado algumas críticas (cf. AUERBACH, 1988) quanto a uma preocupação exclusiva de Shepard com o universo masculino em detrimento da abordagem de traços da psique feminina (SHEWEY, 1997, p.90,99-100). Na seção seguinte, apresentamos contraexemplos dessa visão no âmbito da produção do autor e discutimos passagens de peças e contos que viabilizam o aprimoramento do papel social das mulheres.

\subsection{Subjetividades femininas}

Durante a fase inicial da carreira de Shepard, alguns aspectos de suas peças foram avaliados de maneira negativa por críticas feministas, que argumentaram que seus espetáculos estavam mais preocupados com aspectos da psique do macho e mantinham uma postura relativamente misógina (BOTTOMS, 2002, p.42). Peças como A Lie of the Mind, em que uma mulher é espancada e quase morta pelo marido (1986, p.10-11), e The Late Henry Moss, na qual uma esposa é agredida a pontapés diante dos filhos (2002b, p.99-100), ou filmes como Silent Tongue (EUA, Reino Unido, França, 1992), roteirizado e dirigido por Shepard, em que mulheres indígenas são estupradas, vendidas, trocadas ou "fragmentadas" (o título do filme se refere a uma nativa americana que teve a língua extirpada por ter mentido a

\footnotetext{
${ }^{29}$ a warm hand landed softly on my chest. [...] there might be grown men in this world who actually get a spark out of life and somehow manage to dodge the black hole my dad had fallen into.
} 
um homem branco) ajudaram a criar em torno do autor uma reputação de sexista. ${ }^{30}$ Nesse sentido, suas produções teatrais apenas atuariam no sentido de reafirmar a ordem simbólica patriarcal por meio do discurso heteronormativo do macho, que, como sabemos, relega a mulher a uma posição de subalternidade ou de mero objeto das violências e negociações de poder entre os homens (McDONOUGH, 2002, p.156).

A escritora Annie Proulx, cuja inspiração pode-se dizer que também venha em parte da vida rural americana na região oeste dos Estados Unidos, tem recebido críticas similares pelo fato de as figuras centrais em seus textos serem sempre homens. A autora de contos como "Brokeback Mountain" (1997) e "Tits-Up in a Ditch" (2008), defende-se, no entanto, dizendo que, em virtude de suas histórias serem sempre repletas de atividades ao ar livre ações que, em estados como o Wyoming, são executadas predominantemente por homens o foco tenha de ser o universo masculino:

[As mulheres] não eram o centro das histórias porque a maior parte do trabalho, seja pescaria ou a lida no rancho ou seja lá o que for, era feita por homens. De maneira natural, sucedese que os homens terão posições centrais nas histórias sobre o Wyoming. É uma questão mais de geografia do que algo baseado nos sexos (PROULX, 2009, p.41-42). ${ }^{31}$

De maneira semelhante, podemos considerar que a presença maior de caubóis, rancheiros, domadores de cavalo, fazendeiros e outras figuras masculinas ligadas a trabalhos tradicionalmente viris em textos de Shepard deve-se antes aos aspectos sociais e culturais do enclave geográfico ficcionalizado pelo autor do que a atitudes sexistas.

Porém, conforme veremos, essas críticas tomam como referência a figura do homem como centro das relações de poder e tendem a ignorar que essa é justamente a noção que o trabalho de Shepard em diversos gêneros tenta minar. Embora várias de suas peças, contos,

\footnotetext{
${ }^{30}$ Essa crítica também se aplica a João Gilberto Noll, cujas narrativas, com raras exceções, dedicam-se a uma exclusiva representação da supremacia masculina. As mulheres em geral ocupam posições subalternas e aparecem associadas a imagens de violência física e sexual, além de sofrerem fragmentações (a personagem Cris do romance Harmada mutila a própria língua) em nível corporal e psicológico. O próprio Noll afirmou em estrevista que suas "personagens masculinas centrais têm um certo desdém pelo mundo, pelas mulheres" (WEIS, 1997, p.93, grifo nosso).

31 They weren't in the center of the stories because the major work, whether it's fishing or ranching or whatever, was done by men. It naturally falls that men are going to have central positions in stories about Wyoming. It's a geography thing more that something based on gender.
} 
roteiros sejam dominadas por presenças masculinas intensas, o traço distintivo desses textos consiste em deslocá-los da posição tradicional de poder por meio da exploração de seus conflitos internos e fraquezas.

Em recente montagem da peça The Late Henry Moss (2000), por exemplo, os dois filhos adultos da personagem-título descobrem que seu finado pai - cuja morte deu-se em isolamento, quando este já estava completamente arruinado pelo alcoolismo — viveu seus últimos dias em intenso tormento, pois achava que "o mundo estava tentando comê-lo" (SHEPARD, 2002b, p.33). ${ }^{32}$ Além desse medo irracional, o velho Henry Moss, dias antes de morrer, experimenta dificuldades ao tentar provar à namorada, Conchalla Lupina, que ainda está vivo muito embora ela já o tenha dado como morto, em uma clara tentativa de desacreditar a voz de autoridade conferida ao homem por tradição. Em uma cena carregada de simbolismo, Henry, ao voltar de uma pescaria, coloca os peixes dentro da banheira na qual Conchalla está se banhando. Ela pressiona um deles entre as coxas nuas e depois o come vivo, em uma clara sugestão da emasculação do macho dominante (Id., ibid., p.77-78).

Desse modo, podemos perceber que Shepard não fornece uma versão paradigmática do indivíduo do sexo masculino imbuído de poder, mas projeta, desde suas primeira peças, um sujeito em crise com sua própria identidade como amante, pai e sobretudo como homem. De acordo com Carla J. McDonough, "no mundo de Shepard, a estrutura patriarcal enfraquece não só as mulheres, que são subjugadas de modo explícito por ela, mas também os homens que deveriam se beneficiar dessa estrutura" (2002, p.169). ${ }^{33}$ As metáforas do mundo e da fêmea que ameaçam devorar / emascular Henry Moss mostram um macho impotente, que há muito deixou de ser predador e passou a ser presa do Outro, antigo objeto de sua dominação. Essas imagens podem ser associadas ao descrédito em relação à legitimidade da ordem simbólica patriarcal como autoridade, mas também indicam, como veremos adiante, um abalo da noção do sujeito estável.

A inscrição dessas imagens e seres ficcionais que contribuem para a dissolução do discurso hegemônico da ordem simbólica patriarcal é marcante na escrita de Shepard em vários gêneros. No teatro, por exemplo, há um tratamento substancial das subjetividades femininas em peças do autor como Little Ocean (1974), um espetáculo dominado por

\footnotetext{
${ }^{32}[\ldots]$ the world was trying to eat him.

${ }^{33}$ In Shepard's world, the patriarchal structure fails not only the women who are explicitly subjugated by it but also the men who are supposed to benefit from it.
} 
personagens femininas, envolvendo temas relacionados à maternidade (SHEWEY, 1997, p.90; ABBOTSON, 2002, p.307). Esse texto não foi publicado e teve uma única montagem em Londres, sob direção de Stephen Rea. Em Curse of the Starving Class, por exemplo, a encenação de imagens de desobediência e libertação associadas à personagem Emma, uma jovem que se recusa a representar o papel socialmente estabelecido como "natural" ao seu gênero (ADLER, 2002, p.113), contribui para reinventar e fortalecer a própria subjetividade feminina. Um outro exemplo inclui a personagem Beth da peça A Lie of the Mind. Embora seja literalmente silenciada pelo macho dominante, que a espanca a ponto de causar-lhe danos encefálicos e afasia (SHEPARD, 1986), a personagem, por meio de sua linguagem "fraturada", questiona os papéis convencionais dos sexos, revelando tanto a arbitrariedade quanto o caráter precário do poder masculino (McDONOUGH, 2002, p.157-159).

No âmbito da narrativa, um fato marcante em relação às coletâneas anteriores é o de que vários dos contos reunidos em Great Dream of Heaven são protagonizados quase exclusivamente por personagens femininas ou narrados pela perspectiva da mulher. Dentre esses textos, destaca-se o conto "Berlim Wall Piece", no qual o(a) narrador(a) adolescente, como vimos no capítulo I, enfraquece a voz de autoridade do pai ao iniciar o texto com a frase "Meu pai não sabe absolutamente nada", e então demonstra que sua irmã possui uma capacidade intelectual superior ao do patriarca da família. Esse dado mostra, no plano da ficção, uma relativa mudança social nos padrões de educação e emprego na pós-modernidade, conforme já apontada por estudo de Plant (1996), favorecendo as mulheres e mostrando o crescente sucesso intelectual das garotas em relação aos garotos (p.181). Essa tendência pósmoderna, no entender de Gregson (2004), coloca em crise a supremacia masculina e, por conseguinte, abala os sistemas culturais baseados em noções que equacionam a perspectiva e os valores masculinos a normas universais (p.111).

Outro exemplo de afirmação feminina e desnaturalização dos padrões normativos falocêntricos ocorre no conto "Betty's Cats", no qual a personagem-título, uma mulher pobre que vive em um trailer imundo e desnivelado com dezenas de gatos, corre o risco de ter sua moradia confiscada pelo departamento de saúde pública caso não se livre dos animais. O conto mostra um diálogo entre Betty e uma outra pessoa cujo sexo ou relação com a protagonista não podem ser determinados. Essa segunda personagem tenta convencer Betty do sério problema representado pelos gatos, em especial um animal que nasceu sem qualquer pelo, mas a dona prefere mantê-los como são, sem julgá-los, nem controlá-los: 
- Eu estava só dizendo - se você quisesse se livrar de alguns deles você poderia começar com aquele um, pois ele não tem pelo.

— Não há nada de errado com ele. Ele só é diferente.

- Ele tem alguma coisa. Não é natural para um gato não ter pelo. [...] Bom, que tal um dos outros então. Aquele alaranjado.

— Que alaranjado? [...] Badger? [...] Badger é o pai.

— Você deveria ao menos mandar castrá-lo então.

— Eu não vou mandar castrar o Badger. Ele é o papai.

- Então você só vai continuar tendo mais e mais filhotes, Betty (SHEPARD, 2002a, p.39-40). ${ }^{34}$

Alguns críticos consideraram a atitude da moradora como desleixada ou mesmo irresponsável (TARQUINIO, 2002, p.2; ATHERTON, 2002, p.1), mas sua postura tem uma conotação mais política, nessa pequena alegoria que lembra A revolução dos bichos (1945), de Orwell. Em um nível mais abstrato de significação, os gatos de Betty podem ser lidos como representações de indivíduos inocentes vivendo sob um regime político que dita padrões rígidos de conduta e promove limpeza étnica. Betty discorda dos mecanismos de biocontrole, representados pelo departamento de saúde, mobilizados pelos aparelhos estatais, um tema já explorado por Shepard na peça The Unseen Hand (1970), recusando-se a compactuar com o sistema totalitário de poder, que exclui o Outro e controla com sua "mão invisível" até o comportamento sexual dos indivíduos. Desse modo, a resistência ao impulso controlador, tradicionalmente vinculado ao legado patriarcal dominante, é indexado sob várias formas em "Betty's Cats": tanto na afirmação da subjetividade feminina da protagonista - que se recusa a assumir uma postura masculinizada de tirano e impor controle sobre seus, digamos, subordinados - quanto na própria narrativa, que leva o "modo dramático" de Friedman (1975, p.155-156) a extremos ainda mais radicais, apagando por completo a voz "ditatorial" do narrador como centro ordenador do discurso.

\footnotetext{
${ }^{34}$ I was just saying - if you wanted to get rid of some of them you could start with that one, since he's got no hair. / There's nothing wrong with him. He's just different. / He's got something. That's not natural, for a cat to have no hair. [...] Well, how about some of the other ones then. That orange one. / Which orange one? [...] Badger? [...] Badger's the daddy. / You ought to at least have him neutered then. I I'm not neutering Badger. He's the daddy. I Then you're just going to keep having more and more litters, Betty.
} 
Embora esses exemplos não resolvam por completo a questão das subjetividades femininas na produção artística de Sam Shepard, eles indiciam uma crescente preocupação do autor e dramaturgo com as complexas relações envolvidas nos processos de individuação dos sujeitos humanos de ambos os gêneros.

Contudo, antes de analisarmos mais detidamente como essas subjetividades se manifestam no contexto ficcional do autor, precisamos tecer algumas considerações acerca de como algumas teorias recentes tentam entender o sujeito pós-moderno. Por essa razão, expomos, a seguir, alguns aspectos de teorias que fundamentam estudos da identidade e discutimos três concepções distintas de subjetividade: o sujeito do Iluminismo, o sujeito sociológico e o sujeito pós-moderno.

\subsection{Identidades fragmentárias}

Questões relacionadas à identidade têm sido motivo de intensa reflexão em diferentes campos do conhecimento, sobretudo, no período histórico atual, no qual observamos ocorrerem profundas transformações históricas, fenômenos sociais complexos, a sofisticação tecnológica e uma nova configuração do capitalismo no ocidente, chamado por Ernest Mandel de "capitalismo tardio" (JAMESON, 2006, p.22-23). Essas intensas transformações representam um momento crucial dentro de um longo processo de perda de poder e influência de instituições responsáveis pela mediação dos valores sociais.

Há mais ou menos três séculos, acreditava-se que instituições como, por exemplo, família nuclear, Estado e Igreja, garantiam a unidade e a coerência das sociedades (BAUMAN, 2004, p.23). Os sujeitos formados nesse contexto emergiam como seres unificados, cujo cerne era, por um lado, a razão, e por outro, a fé na existência de uma alma imortal, responsável por uma posição de sujeito — isto é, identidade - contínua e centrada. A passagem abaixo, retirada de Shakespeare, ilustra a noção de profunda coerência interna do eu (self) de Romeu, expresso na fala de Julieta:

JULIETA: Oh, não jures pela lua, a inconstante lua Que sofre alterações mensais em seu globo circular, Para que teu amor não se mostre do mesmo modo variável. 
ROMEU: Pelo que jurarei então?

JULIETA:

Não jures em absoluto;

$\mathrm{Ou}$, se quiseres, jura pelo teu gracioso ser [self],

Que é o deus da minha idolatria,

E em ti eu crerei (2006, p.174). ${ }^{35}$

Por meio do diálogo inscrito na tragédia elisabetana, observamos que a personagem opõe claramente a mutabilidade da lua à extrema fixidez intrínseca atribuída ao sujeito (Romeu), que, ao ser também associado à figura de deus, sugere autossuficiência, centralidade e onipotência.

Stuart Hall, em "The Question of Cultural Identity" (1992) define esse indivíduo como o "sujeito do Iluminismo", pois ele é dotado de capacidades de raciocínio, consciência e ação (p.276). Embora a peça de Shakespeare anteceda a emergência do chamado Século das Luzes, identificamos na passagem uma possível figuração do tipo de sujeito plenamente estabilizado, que mais tarde seria teorizado pelos filósofos iluministas. Os subsídios teóricos de Hall, por exemplo, provêm de posições filosóficas como as de Locke. Segundo o iluminista inglês, o que define a identidade do sujeito humano é sua consciência reflexiva, isto é, o conjunto das faculdades responsáveis por relacionar ações, percepções e experiências passadas e presentes em um todo consistente. No Ensaio acerca do Entendimento Humano (1690), Locke expõe essas ideias da seguinte maneira:

Uma vez que a consciência sempre acompanha o
pensamento; e, por meio disso, distingue-se [o sujeito
humano] de todos os outros entes pensantes, nisto apenas
consiste a identidade pessoal, isto é, a uniformidade de um
ser racional: e tanto quanto esta consciência pode ser
extendida de maneira retroativa a qualquer ação de
pensamento passada, tanto alcança a identidade da pessoa;

${ }^{35}$ JULIET: O, swear not by the moon, the inconstant moon, / That monthly changes in her circled orb, / Lest that thy love prove likewise variable. / ROMEO: What shall I swear by? / JULIET: Do not swear at all; / Or, if thou wilt, swear by thy gracious self, / Which is the god of my idolatry, I And I'll believe thee. 
trata-se da mesma personalidade agora tal como era então (1959, p.449, grifos nossos). ${ }^{36}$

Em síntese, esse sujeito projetado pelas ideias iluministas, também chamado de "sujeito monádico", caracteriza-se como um núcleo uniforme e autossuficiente cuja formação dá-se antes pela conformidade dos processos mentais dentro da consciência (vista aqui como entidade reificada) do que pela interação - isto é, consciência como processo - com elementos da realidade exterior. Conforme sintetiza Docherty (1993), esse sujeito do Iluminismo estaria "reduzido à participação ou confirmação de seus próprios processos racionais em vez de comprometer-se em participar da alteridade material de um mundo objetivo" (p.8). ${ }^{37}$

O relativo declínio dessas instituições, fato que marca a modernidade, dá origem a indícios de ruptura na própria trama de algumas sociedades. Surge entre os indivíduos uma tendência a examinar e a reformular os valores e comportamentos recorrentes do passado associados a essas instituições tradicionais em face do apelo livre de outras forças concorrentes e discursos competitivos forjados na conjuntura socioeconômica moderna.

Nesse contexto de grande complexidade, Hall distingue o desenvolvimento da noção de um "sujeito sociológico", constituído a partir da consciência de que o núcleo interno do sujeito não é mais autônomo, como ocorria no sujeito do Iluminismo ou cartesiano, mas é formado em relação a outros sujeitos significativos, responsáveis por mediar os valores, símbolos e sentidos ao sujeito sociológico (HALL, 1992, p.276). Conforme observa o teórico em "Minimal Selves” (1987), esse processo se daria como se “quem eu sou — o 'verdadeiro' eu — fosse formado em relação a todo um conjunto de outras narrativas" (p.44). ${ }^{38}$ Por essa razão, a identidade é (trans)formada a partir de atos de interação entre o eu, ainda em posse de um núcleo uniforme (o "verdadeiro" eu), e a sociedade, que fornece significados e valores culturais aos quais o sujeito tenta se alinhar. A identidade, dessa forma, é a sutura do sujeito na estrutura sociocultural, que, até o alto modernismo, ainda pode ser definida como

\footnotetext{
${ }^{36}$ Since consciousness always accompanies thinking; and thereby distinguishes himself from all other thinking things, in this alone consists personal identity, i.e. the sameness of a rational being: and as far as this consciousness can be extended backwards to any past action of thought, so far reaches the identity of the person; it is the same self now it was then.

37 [...] reduced to an engagement with and a confirmation of its own rational processes rather than being committed to an engagement with the material alterity of an objective world.

${ }^{38}$ Who I am - the 'real' me - was formed in relation to a whole set of other narratives.
} 
unificada e previsível (HALL, 1992, p.276). Essa noção de previsibilidade do local que o sujeito deve ocupar emana, segundo Zygmunt Bauman (2004), da noção de que durante a maior parte da modernidade, a ideia das classes sociais, por exemplo, era muito mais forte e, dessa forma, a posição de sujeito era determinada por uma trajetória inequívoca. Nesse sentido, Bauman observa que "no âmbito dessa rede de familiaridade, do berço ao caixão, o lugar de cada pessoa era evidente demais para ser ponderado, muito menos negociado" (p.18). ${ }^{39}$ Devido a essa consciência de pertencimento a uma classe, o sujeito sentia-se confortável o bastante para perceber-se como parte de um corpo coletivo e desenvolver o que o teórico chama de tripla confiança: em si mesmo, nos outros e na sociedade (BAUMAN, 2004, p.48-50).

No entanto, as atuais configurações do capitalismo tardio aliadas ao fenômeno da pós-modernidade, com seus enormes avanços em termos de mobilidade, tecnologia e comunicação, têm abalado as antigas formas de identidade e, por essa razão, fornecido uma arena propícia para o surgimento não de uma identidade centrada, unificada e coerente, mas de identidades fragmentárias, instáveis e em permanente construção (HALL, 1992). Como atesta Bauman, a "fragilidade e a condição eternamente provisória da identidade não podem mais ser ocultadas" $\left(2004\right.$, p.16)..$^{40}$

Nesse mesmo sentido, Rincón (1995), com base em aspectos socioculturais do capitalismo tardio, propõe a seguinte distinção entre formulações clássicas de sujeito e o sujeito pós-moderno:

O sujeito reflexivo, centrado e unitário das Kritiken de Kant e das abstrações de Max Weber teria sido substituído por um cambiante sujeito descentrado, difuso e fragmentário, que se move em um espaço que já não está socialmente estruturado de uma maneira binária. Com isso, a questão da constituição de identidades também foi reformulada (p.111). ${ }^{41}$

Por essa razão, o caráter frágil e temporário das identidades humanas é em geral percebido como a chamada crise de identidade, cuja precipitação deve-se à derrocada da

\footnotetext{
${ }^{39}$ Inside that network of familiarity from the cradle to the coffin, each person's place was too evident to be pondered, let alone negotiated.

${ }^{40}$ The frailty and the forever provisional status of identity can no longer be concealed.

${ }^{41}$ El sujeto reflexivo, centrado y unitario de las Kritiken de Kant y de las abstracciones de Max Weber habría sido reemplazado por un cambiante sujeto descentrado, difuso y fragmentario que se mueve en un espacio que ya no está socialmete estructurado de una manera binaria. Con ello, la cuestión de la constitución de identidades también fue replanteada.
} 
soberania e influência dos chamados "monopólios de interpretação" (SANTOS, 2000, p.89), representados pelas instituições (e suas narrativas mestras), cujo papel consistia em fornecer referenciais sólidos para o processo de individuação dos sujeitos. Lyotard, como sabemos, associa esse declínio das instituições a uma crise geral de legitimação das narrativas mestras. Segundo o pensador, a recente "incredulidade em relação aos metarrelatos" constitui um sintoma da possibilidade sem precedentes de se "questionar a validade das instituições que regem o vínculo social" (1988, p.xvi).

Hall distingue, nesse contexto, a produção de um "sujeito pós-moderno", concebido como desprovido de uma identidade fixa, essencial ou permanente (1992, p.277). Isto é, um sujeito encarado como ponto de convergência e divergência simultânea de identidades contraditórias, que o impulsionam em diferentes sentidos, forçando-o a intercambiar posições de sujeito como se fossem peças do vestuário. Nesse sentido, Bauman sugere que o mais sensato na pós-modernidade (ou "modernidade líquida", como o autor prefere definir a dominante cultural contemporânea) seria a possibilidade de "vestir" identidades como "uma capa leve pronta a ser tirada a qualquer momento" (2004, p.30). ${ }^{42}$

Observadas as devidas proporções, podemos afirmar que as complexidades do sujeito humano e a possibilidade deste, com relativa frequência, trocar de identidades tem sido uma preocupação de Sam Shepard desde seus primeiros textos (McGHEE, 1993, p.169170; SHEWEY, 1997, p.45). A peça True West trata das rivalidades entre dois irmãos que, a certa altura, trocam de identidades, profissões e vícios. Esse intercâmbio de posições de sujeito resulta em crises de identidade e frustrações, que os levam afinal a tentar assumir a identidade do pai ausente. Em uma montagem de 2000, os atores John C. Reilly e Philip Seymour Hoffman, que interpretavam o passivo Austin e o sociopata Lee, trocavam não só de identidade dentro da peça, mas trocavam também de personagem a cada duas noites de apresentação da peça na Broadway, confundindo tanto expectadores e críticos como também membros do prêmio Tony, ao indicá-los para a categoria de melhor ator (ROUDANÉ, 2002, p.69).

Situação semelhante ocorre com várias personagens da peça Simpatico: o fracassado Vincent "Vinnie" T. Webb "rouba" a identidade de seu ex-sócio e comparsa Lyle

\footnotetext{
${ }^{42}[\ldots]$ a light cloak ready to be taken off at any time.
} 
Carter $^{43}$ com a finalidade de vender fotografias comprometedoras a Darrel P. Simms, um terceiro envolvido em suas trapaças do passado. Ao visitá-lo, Vinnie encontra esse obscuro sujeito já em posse de um novo nome (Ryan Ames) e empresa, em torno da qual forjou uma identidade completamente nova. Durante o confronto final de Vinnie com Simms (que finge ser Ames), este último indaga: "Quantas vidas o senhor acha que um homem pode viver, Sr. Webb? Quantas vidas dentro desta mesma vida?" (SHEPARD, 1996b, p.61, grifo nosso). ${ }^{44}$ A julgar por esses e outros textos do autor, as identidades (ou diferentes "vidas" dentro de uma única vida) são portanto temporárias, flexíveis e tendem a acompanhar a extrema mutabilidade e volatilidade dos sujeitos ficcionais, conforme veremos em análises de contos do livro Great Dream of Heaven.

No que segue, examinamos manifestações estilizadas dessas três concepções de sujeito no conto "Coalinga 1/2 Way". A proposta de análise baseia-se no método adotado por Aronowitz (1995), que "monitora" o impacto exercido por diferentes perspectivas identitárias sobre as posições de sujeito de um trabalhador portorriquenho fictício durante momentos distintos da história americana (p.115-116). No caso do conto "Coalinga $1 / 2$ Way", três perspectivas de identidade enformam o progressivo declínio emocional de um pai de família (family man) americano comum.

\subsection{Multiplicação/Dissolução de identidades em Shepard}

“Coalinga 1/2 Way" (SHEPARD, 2002a, p.11-18) ${ }^{45}$ é o segundo conto do livro Great Dream of Heaven. O texto - uma provável reelaboração de um microconto publicado em Motel Chronicles (1982, p.121) — narra a breve viagem do protagonista, que vai possivelmente da região de San Francisco, Oakland ou Sacramento, no estado da Califórnia, até Los Angeles. O interesse da história nessa jornada em particular deve-se ao fato de que o homem, cujo nome não é referido no texto, está deixando sua esposa e filho para juntar-se a

\footnotetext{
${ }^{43} \mathrm{Na}$ adaptação da peça para o cinema (Simpatico, EUA, 1999), o diretor inglês Matthew Warchus buscou ressaltar a semelhança física entre os atores Nick Nolte e Jeff Bridges, que interpretam Vinnie e Carter, respectivamente, com o intuito de reforçar a ideia de que, embora sujeitos diferentes, ambos são as "metades divididas da mesma alma em busca de uma impossível reconciliação" (HOLDEN, 2000, p.17).

${ }^{44}$ How many lives do you think a man can live, Mr. Webb? How many lives within this one?

${ }^{45}$ Este conto foi publicado em português sob o título de "Coalinga metade do caminho" (SHEPARD, 2003). Nossa análise baseia-se, entretanto, na versão original em inglês.
} 
uma outra mulher, também casada. Tendo em vista o fato de que o protagonista faz uma pausa na região mencionada no título do conto com a finalidade de telefonar para a mulher e só então avisá-la de que a está deixando, percebemos que a ideia de abandoná-la partiu de uma decisão irrefletida e, conforme ele descobrirá mais tarde, precipitada. O local escolhido por ele para contactar a esposa é saturado de imagens negativas: uma cabine telefônica à beira do acostamento poluído, ladeada por um enorme campo de confinamento de gado de onde se avista todo o vale San Joaquin sob o sol escaldante.

O diálogo com a esposa tem um tom seco, quase trágico, pois o protagonista não tem respostas quando ela indaga-lhe os motivos do fim de um casamento de mais de quinze anos. Como é típico das figuras masculinas em Shepard, essa personagem parece incapaz de articular sentimentos e emoções em sua fala, que é marcada por reticências e hesitações incômodas. A mulher pede-lhe que volte, mas ele lhe diz que já viajou demais para retornar. Ela então se propõe a viajar metade do caminho e, em um último esforço de reconciliação, pede-lhe que também retorne a outra metade. ${ }^{46}$ Dessa maneira, os dois poderiam se encontrar em algum ponto do caminho. Em termos metafóricos, isso equivale a dizer que ambos poderiam encontrar um meio-termo satisfatório e diminuir a distância existente entre eles. Contudo, dada a incompatibilidade irreconciliável dos elementos masculino e feminino no horizonte da poética de Shepard, o homem recusa-se a tentar encontrar-se com a mulher no meio do caminho.

Após uma breve discussão sobre qual dos pais deve comunicar a separação ao filho do casal, Spence, o homem encerra o diálogo com a antiga companheira, que lhe faz a ominosa pergunta: "para onde eu devo ir?" Ele então retoma a viagem em sua caminhonete Dodge $e^{47}$ e chega a Los Angeles à noite. Durante o percurso até o hotel o protagonista é "bombardeado" por estranhas imagens da cosmópole pós-moderna: astros e estrelas do cinema em cenas de explosão ou simulações de orgasmos em painéis e outdoors espalhados pelo trajeto; limusines

\footnotetext{
${ }^{46}$ Shepard já havia utilizado imagem semelhante, embora com efeito cômico, na peça La Turista, em que um garoto explica que vai se encontrar com o pai: "Ele disse para eu começar a caminhar pela estrada em direção à casa e ela começará a caminhar na minha direção e nós vamos nos encontrar no meio do caminho e nos abraçar. [...] Minha casa é longe daqui. Nós vamos nos encontrar quando o sol nascer. Vamos nos ver de longe e cada um de nós terá a impressão de que somos anões. Ele me verá e eu o verei, e ficaremos cada vez maiores na medida que nos aproximamos um do outro" (2002b, p.276).

47 Além do emprego desta palavra em "Coalinga 1/2 Way", significando a marca do veículo utilizado pelo pai durante a fuga da família, Shepard já utilizou esse mesmo termo ao menos mais uma vez para nomear o patriarca alcoólatra e cruel na peça Buried Child (2005a, p.62). Ao associar a palavra dodge, que significa "desviar", "esquivar-se" ou "evadir", a figuras paternas, o autor provoca uma ressignificação do termo, reforçando o caráter negligente e intratável desses pais de família ficcionais.
} 
com vidros escuros; adolescentes com piercings sendo revistadas na entrada das boates; pessoas sozinhas e drogadas. O homem hospeda-se no hotel Tropicana "sem bagagem, nem escova de dentes, nem uma troca de roupa de baixo" (p.17). ${ }^{48} \mathrm{O}$ quarto tem cheiro ruim e oferece apenas uma cama e um telefone, que ele usa para entrar em contato com a outra mulher, com quem manteve uma relação ambígua de dois anos. Na verdade, o texto não esclarece se o protagonista teve algum outro contato - incluindo o visual - com essa mulher a não ser por telefone. Ela fica surpresa com a decisão do protagonista e recusa-se a ir até o hotel encontrá-lo, pois está a ponto de embarcar para Indiana, no extremo oposto do país, onde seu marido acaba de receber uma proposta de trabalho e está a sua espera. Desnorteado, o protagonista replica a indagação feita horas antes por sua esposa: "Para onde eu devo ir?" (p.18). ${ }^{49}$

Embora pontuada por um curso de eventos banais envolvendo personagens e situações superficiais, essa pequena narrativa, em um nível mais simbólico, constitui um comentário sobre o desfacelamento de uma visão tradicional e unitária do oeste americano por meio de um processo de degradação física e emocional da personagem. O protagonista anônimo do conto é um ser ficcional recorrente em trabalhos anteriores do autor como True West e Paris, Texas. Trata-se de um pai (old man) que não se identifica com a vida nem tampouco com os valores associados à vida em comunidade e, em especial, à família como vínculo social; e, sem aviso, decide romper com esses laços, tornando-se "patologicamente independente" (HALL, 2002, p.247). ${ }^{50}$ No caso do protagonista de "Coalinga $1 \frac{1}{2}$ Way", o motivo alegado por ele para a ruptura é a união com uma outra mulher. Mas, em face da surpresa da outra pessoa e a aparente falta de relação entre os dois, percebemos que a partida tem menos que ver com a busca de uma nova relação do que com um desejo inconsciente de desfazer-se de compromissos e isolar-se. O texto deixa claro que o narrador já agiu dessa maneira antes e embora relute em seguir sua "sina", parece compelido a fazê-lo devido ao mesmo imperativo que levou seu próprio pai a também abandonar a família. O confinamento de gado em Coalinga sugere aprisionamento e ausência de escolha e prefigura o impasse vivido pela personagem. Embora não desejasse cometer os erros do pai, sente-se fadado, devido a uma linhagem "hereditária" inelutável, a replicar os comportamentos do patriarca; afinal, não há

\footnotetext{
${ }^{48}[\ldots]$ no bag, no toothbrush, no change of underwear.

49 Where am I supposed to go?

${ }^{50}$ patologically independent.
} 
volta, pois ele está agora "profundamente dentro do músculo de uma ação"51 alheia ao seu controle. A conversa com a esposa deixa claro os traumas causados por esse padrão masculino de fugas e abandonos recorrentes no ânimo de ambos:

- Você sabe o que isso [o abandono] significa para mim, não sabe? Quero dizer, minha história e tudo... meu pai...

- É, eu sei. [responde o protagonista].

- O seu pai também.

- É.

— Você não pensou nisso?

- Pensei. $(\text { p. } 14)^{52}$

Já mencionamos que os dilemas das personagens de Shepard são vivenciados em um espaço emocional (WETZSTEON, 2006, p.7) e, por essa razão, devemos entender cada etapa do deslocamento do protagonista como elemento simbólico que indicia o desfacelamento do sujeito centrado. O tema da viagem em geral revela muitos aspectos da vida dos seres ficcionais e pode evocar traços do destino humano em um sentido mais amplo, pois a jornada tem muitos significados não apenas em termos de contrastes entre regiões e paisagens, mas também no que diz respeito aos sentimentos e às transformações experimentadas pelo viajante. No território ficcional de Shepard, "o local em que [um indivíduo] cresce e vive molda de forma invisível a maneira como este pensa, percebe a realidade e relaciona-se com o ambiente". Por essa razão, as personagens do autor tendem a encarar o deslocamento dessa rede de familiaridade como uma "fonte de grande perturbação pessoal", capaz de deixar a "psique [...], de uma maneira misteriosa, em desacordo" (DeROSE, 1992, p.58). ${ }^{53}$ Dessa maneira, lemos o deslocamento do protagonista em ao menos dois sentidos: o afastamento do protagonista de um ambiente de familiaridade rumo a um outro de estranhamento; e a trajetória de deslocamento da ideia de sujeito centrado rumo a uma concepção pós-moderna de identidade. Nesse sentido, o motivo da viagem figura como metáfora do caráter necessariamente móvel da identidade. O teórico Tomaz Tadeu da Silva explicita essa noção nos seguintes termos:

\footnotetext{
${ }^{51}[\ldots]$ deep inside the muscle of an action $[. .$.$] .$

52 "You know what this is for me, don't you? I mean my history and everything - my father_—" / "Yeah, I do" / "Your father too" / "Yeah" / "You didn't think of that?" / "I did".

${ }^{53}$ the place in which one is raised and lives invisibly shapes the way one thinks, perceives reality, and relates to the environment. [...] source of personal agitation [...] the psyche is mysteriously at odds.
} 
Embora menos traumático que a diáspora ou a migração forçada, a viagem obriga quem viaja a sentir-se 'estrangeiro', posicionando-o, ainda que temporariamente, como o 'outro'. A viagem proporciona a experiência do 'não sentir-se em casa' que, na perspectiva da teoria cultural contemporânea, caracteriza, na verdade, toda identidade cultural. Na viagem, podemos experimentar, ainda que de forma limitada, as [...] inseguranças [...] da instabilidade e da precariedade da identidade (2005, p.88).

Nos textos de Shepard, a condição pós-moderna, por meio de seus elementos artificiais e fragmentários, instaura uma conjuntura social e cultural extremamente desfavorável para o sujeito humano e para os ideais de autenticidade e unidade do oeste americano cristalizados no imaginário nacional desde o final do século XIX. Dessa maneira, podemos afirmar que Shepard é um autor que pode ser associado ao pós-modernismo, porém, que, ao mesmo tempo, produz textos que, de maneira paradoxal, resistem e opõem-se à pós-modernidade. Suas peças e contos com frequência projetam sentimentos de insatisfação com as condições existentes na contemporaneidade e manifestam uma preferência por uma miragem de uma América mais "natural". O problema com essa mirada nostálgica reside no fato de ela se constituir em uma espécie de desejo paradoxal por uma determinada imagem de nação, que provavelmente jamais existiu, a não ser em romances e filmes Western ou, conforme nota Görmez, em subgêneros televisivos como propagandas do cigarro Marlboro (2007, p.142).

Como assinala King (1988), algumas produções artísticas de Shepard são marcadas por fusões espúrias entre elementos contrastantes como, por exemplo, a coexistência simultânea de duas ou mais temporalidades distintas em uma mesma cena ou narrativa (p.ix). Esse também é o caso de textos em que convivem em um mesmo espaço-tempo duas "metades" ou duas ou mais "versões" da mesma personagem (DEMASTES, 1987, p.237-241). Embora de maneira menos experimental que peças como True West e Buried Child, podemos dizer que o deslocamento empreendido pelo protagonista de "Coalinga 1/2 Way", conforme veremos, abrange temporalidades distintas dentro do "mesmo" dia, bem como fragmenta a ideia de sujeito inteiro em função de uma justaposição de diferentes posições de sujeito fluidas da mesma personagem.

Dessa maneira, devemos ler a trajetória do protagonista de "Coalinga 1/2 Way" como uma alegoria do processo de fragmentação do sujeito centrado. Por essa razão, devemos pôr a questão da temporalidade do conto entre parênteses e, de modo provisório, presumir que esse deslocamento se dá ao longo de um processo histórico e cultural que perpassa toda a modernidade, chegando à concepção pós-moderna de sujeito. 
Podemos distinguir no conto de Shepard três perspectivas distintas do mesmo sujeito, que coincidem com os três modelos de Hall discutidos na seção anterior. A análise a seguir tentará identificar essa tripla perspectiva a partir do estudo de aspectos dos três diferentes tempos e espaços que compõem a narrativa: i) um mês antes da separação, o protagonista encontra-se próximo do lar; ii) durante a fuga, em uma parada na região de Coalinga; iii) ao final da fuga, hospedado em um hotel em Los Angeles.

(i) Em uma digressão, o narrador nos remete a um momento, que, embora narrado na metade do conto, antecede o início propriamente dito da narração. Nesse estágio, pressupomos que o sujeito ainda perceba-se como um sujeito centrado ou monádico. Durante esse flashback, o narrador nos dá conta de que há menos de um mês antes de deixá-la, o protagonista teve uma "conversa imaginária" com a esposa na qual ele lhe dissera que nunca iria deixá-la e que jamais repetiria os erros de seu pai. Como sabemos, "a identidade é relacional", isto é, ela é demarcada pela diferença (WOODWARD, 2005, p.9). Nesse sentido, portanto, o sujeito projetado pelo conto estabelece sua identidade a partir da marcação da diferença radical em relação ao outro (no caso, seu pai ausente) com o qual não se identifica. A figura do pai "traidor" é então percebida como uma alteridade perturbadora em relação aos discursos e valores que estruturam a rede de familiariadade responsáveis pela estabilização da identidade do protagonista.

$\mathrm{Na}$ ocasião dessa "conversa imaginária", ele sentia-se "cheio de convicção" e, ao contrário do pai, tinha "a impressão de si mesmo como um homem honesto" (p.16). ${ }^{54}$ Embora os atos posteriores revelem que de alguma forma ele já nutria, ao menos em nível inconsciente, um impulso de trocar a família por um futuro questionável, parece claro que naquele momento o sujeito ainda dispõe de referenciais consistentes de identificação. Além da família, um desses referentes diz respeito à sua comunhão com a natureza local, representada pelo "vento quente do vale", que lhe fornece uma "fonte de força" (p.16). ${ }^{55} \mathrm{~A}$ possibilidade dessa identificação entre homem e mundo natural remete a um estágio prémoderno, que será eclipsado nas fases posteriores do deslocamento do protagonista. O uso de palavra com valor absoluto (never) para negar qualquer intenção de ruptura com os vínculos sociais dos quais faz parte demandam um grau de certeza e de continuidade que só pode emanar de um sujeito constante (que não prevê mudanças) e consciente ("cheio de convicção") da centralidade desses elementos para a formação de sua própria identidade.

\footnotetext{
${ }^{54}[\ldots]$ full of conviction. The impression of himself as an honest man.

${ }^{55}$ The hot valley wind [...] a source of strength [...].
} 
Além disso, o fato de o sujeito ignorar as evidências do mundo exterior (os abandonos prévios cometidos por seu pai; a possível sensação de domesticidade sentida ao lado da esposa) e concentrar-se em construtos mentais ("conversa imaginária”, promessas) gerados apenas em sua mente com o intuito de convencer a si mesmo, mostram um sujeito que se julga de certa forma autossuficiente e que não depende de outra realidade a não ser a projetada por sua dimensão psíquica. A convicção do protagonista, no entanto, não é imune às instabilidades e, conforme nota James (2002), nas histórias de Shepard, "famílias [...] desmoronam, os homens [...] veem tudo o que acreditam ser verdade virar de cabeça para baixo em um instante" (p.30). ${ }^{56}$

(ii) Em um segundo momento, que coincide com a parada em Coalinga no início da narrativa, o texto fornece uma visão alternativa do protagonista, que acaba de iniciar o processo de deslocamento de seu antigo núcleo de estabilidade para ir em busca de um novo centro de identificação. Embora essa nova relação acabe se mostrando disfuncional, o homem parece crer que ocupando uma outra posição de sujeito, a interação com um círculo diferente de relações vá fornecer sentidos e valores que o ajudem a superar sua crise de identidade momentânea e a redescobrir o seu "verdadeiro" eu. O protagonista acredita que a nova relação com essa outra mulher vá completá-lo de alguma maneira e elege uma parte dela (a voz) como o elemento que tornará completa sua vida: "Ele já pegou o telefone em todos os estados emocionais possíveis, aguardando a voz do outro lado. A voz sem a qual - ele se convenceu — não pode mais viver. A voz pela qual ele desistiu de tudo" (2002a, p.17). ${ }^{57} \mathrm{~A}$ esposa até mesmo o repreende por tentar resolver "essa coisa [...] dentro de você" (p.14, grifo nosso $)^{58}$ com uma troca de mulheres. A mera busca por um outro sujeito significativo não é suficiente para estabilizar sua identidade.

Há alguns elementos que nos levam a ler o espaço ficcional de Coalinga como uma representação da modernidade. O primeiro deles está no fato de que as imagens de morte e devastação - "ossos de rato, latas de cerveja amassada e camisinhas desbotadas"; "absolutamente nada se move, tudo claro até o horizonte cinza esfumaçado" (p.11) mobilizadas pelo narrador para descrever o local evocam o desconforto em relação à modernidade plasmado em versos como "a terra morta, misturando / memória e desejo";

\footnotetext{
${ }_{57}^{56}$ families [...] fall apart, men [...] see everything they believe to be true turned upside down in a flash.

${ }^{57}$ He's gripped phones in every possible emotional state, awaiting the voice on the other end. The voice he's become convinced he can't live without. The voice he's given everything up for.

${ }^{58}[\ldots]$ this thing [...] inside you.

59 [...] mouse bones, flattened beer cans and sun-bleached condoms. [...] Absolutely nothing moves, clear to the smoky gray horizon.
} 
"Quais são as raízes que arrebentam, que ramos crescem / para fora desse entulho pedregoso", de The Waste Land (1922), de T.S. Eliot (1984, p.1894-1895). ${ }^{60}$

Parte da desolação que vemos em "Coalinga 1/2 Way" deve-se à obliteração da natureza como efeito da ação humana, que coloniza a paisagem original com confinamentos de gado, detritos da América consumista, rodovias e telefones públicos. Desse modo, o conto associa o desconforto físico e emocional do protagonista, percebido por meio das imagens mobilizadas pelo texto, aos processos inerentes à modernização avançada.

O contraste entre a aridez naturalmente cinza e o design funcional, tecnológico da cabine telefônica, por exemplo, incomoda de maneira profunda o protagonista: “o [...] modernismo [do telefone] enoja-o; faz com que ele se sinta ainda pior, mais distante" (p.11, grifo nosso). ${ }^{61}$ Nesse sentido, Coalinga emerge como um espaço emocional que representa as instabilidades e deslocamentos intrínsecos à modernidade. Nesse espaço emocional, o sujeito percebe que os discursos, valores e significados que estruturam sua comunidade de identificação estão perdendo a estabilidade. Essa perda é sugerida, no plano da ficção, pelas turbulências da família nuclear, pelo crescente desligamento da natureza, isto é, pelo seu próprio deslocamento físico e afetivo da antiga rede de familiaridade.

O texto projeta, nesse segundo momento, uma concepção sociológica de sujeito, pois embora este se encontre imerso em ansiedades e perdas subjetivas complexas, ainda busca estabelecer uma interação com outro sujeito significativo e tem a percepção de si mesmo como um todo unificado. No tocante à narrativa, esse sentido é sugerido na passagem em que o protagonista "vê a si mesmo à distância nesse momento, como se estivesse olhando de uma grande altura, como da perspectiva de um falcão: um homem minúsculo em um espaço vasto, agarrando-se a um pedaço de plástico preto" (p.15). ${ }^{62}$ Essa mirada privilegiada (do alto, através da visão aguçada da ave de rapina) de si mesmo como um sujeito inteiro, "suturado" a uma estrutura maior, que, mesmo em crise, ainda é capaz de lhe oferecer segurança e firmeza, reforça a relativa unidade da condição moderna.

(iii) Ao aproximar-se do terceiro momento da narrativa, alguns desses aspectos são abalados não só pela consolidação do deslocamento do sujeito de sua rede de familiaridade, mas também pela entrada no território pós-moderno. Se The Waste Land em certa medida expressa o "horror" de Eliot em face da crescente ausência de aspectos da natureza na cultura

\footnotetext{
${ }^{60}$ The dead land, mixing / memory and desire [...] What are the roots that clutch, what branches grow / out of this stony rubbish?

${ }^{61}$ Its modernism disgusts him; makes him feel worse off, more removed.

${ }^{62}$ He sees himself from a distance now, as though looking down from a great height, like the hawk's point of view: a tiny man in vast space, clutching a chunk of black plastic.
} 
moderna (GREGSON, 2004, p.118), a arte de Shepard, por sua vez, assume uma crescente preocupação com a perda total desses elementos pelo sujeito na pós-modernidade.

No caso de "Coalinga 1/2 Way", o local que concentra a cultura, os símbolos, valores e imagens pós-modernos é obviamente Los Angeles, ponto de chegada do protagonista. No domínio teórico recente, Los Angeles aparece em geral como a cosmópole pós-moderna por excelência ou, como define Edward Soja, o "mesocosmo da pós-modernidade" (1989, p.244). ${ }^{63}$ No contexto específico da produção artística de Shepard, Los Angeles costuma figurar como um local repleto de evocações disfóricas, pois este território, que no passado era caracterizada pela natureza rústica, foi "engolido" pelos subúrbios, cuja paisagem circundante não é mais dominada por vales, mas por autoestradas e outdoors, servindo de abrigo à indústria de "ilusões" cinematográficas de Hollywood (CLUM, 2002, p.177). A ocorrência mais intensa dessa ideia encontra-se na peça Angel City (1976), em que Los Angeles é representada como um monstro que "está comendo [as pessoas] vivas" $\left(2005\right.$, p.71). ${ }^{64}$ Essa ameaça de devoração possui tanto um sentido figurado - o risco de aniquilamento do indivíduo em virtude da exploração do artista pela indústria cinematográfica ou da corrupção moral da cidade - quanto um sentido literal: algumas das personagens têm a pele "carcomida" por algum tipo de radiação emitida pela metrópole e, ao final, algumas acabam se transformando literalmente em monstros esverdeados (Id., ibid., p.108). Mais tarde, em um microconto sem título, publicado na coletânea Motel Chronicles, Shepard volta a referir-se a Los Angeles como a "serpente enorme e enlouquecida": "Sua boca aberta repleta de presas, os olhos faiscantes, paralisada em um bote de pura paranoia" (1982, p.121). ${ }^{65}$

A Los Angeles de "Coalinga 1/2 Way" é inanimada. Entretanto, não deixa de pulsar com seres ficcionais e imagens que fornecem um contraste em relação à antiga rede de familiaridade do protagonista. A cosmópole do cinema entretém seus olhos com uma sucessão de simulacros, ${ }^{66}$ cujo referente no real se perdeu ou nunca existiu: imagens brilhantes de artistas, que fingem orgasmos ou fogem de explosões geradas por efeitos virtuais, impressas sobre a superfície sem profundidade dos outdoors; a fachada de neon da

\footnotetext{
${ }^{63}$ Mesocosm of postmodernity.

${ }^{64}$ eating $[\ldots]$ alive.

${ }^{65}$ sprawling, demented snake [...] Its fanged mouth open, eyes blazing, paralyzed in a lunge of pure paranoia.

${ }^{66}$ Termo utilizado aqui no sentido conferido por Jean Baudrillard, segundo o qual a sociedade pós-moderna realizou uma completa substituição das noções de realidade e sentido por símbolos e signos. Desse modo, restaria apenas a experiência do real como simulações. Os símbolos e signos aos quais o teórico alude referemse aos produzidos pela cultura e pela mídia, que levariam as pessoas a confiarem mais nos simulacros do que na realidade, na qual essas mesmas simulações se baseariam. Ainda segundo Baudrillard, o simulacro precede o original e a distinção entre realidade e representação é eclipsada uma vez que não há um saber legitimado capaz de "separar o verdadeiro do falso, o real de sua ressurreição artificial" (1993, p.194-199).
} 
boate exibe uma cor processada artificialmente, sem correspondente na natureza; o logotipo em forma de palmeira do hotel Tropicana remete a uma imagem estereotipada de clima tropical, que é simulada por meio de uma estrutura de neon vermelha. A cidade emerge, portanto, saturada de imagens sugerindo sentidos de ilusão, artificialidade e alucinação. E "na grandeza do devaneio, o eu se perde depressa!" - a frase do pequeno poema em prosa de Baudelaire, emprestada de contexto diverso, pode servir, aqui, de síntese da situação da personagem de "Coaliga 1/2 Way", bem como de prenúncio de seu destino. ${ }^{67}$

A megalópole constitui um espaço social pós-moderno do qual, de acordo com Jameson, a natureza e suas antigas relações com a vida agrária não só desapareceram do campo de visão, mas foram eclipsadas da própria memória (2006, p.365). Por essa razão, a Los Angeles de "Coalinga 1/2 Way" converte-se em um espaço emocional notadamente desconfortável para o protagonista, que em meio a esse ambiente, assume as características de um sujeito deslocado. Esse deslocamento de um sistema consistente de representação cultural - seu território natural, sua comunidade e sua família nuclear - rumo a um campo de forças marcado por imagens inautênticas e discursos competitivos, levam-no a experimentar perdas subjetivas.

Esses prejuízos incluem a substituição do papel central no vínculo estável com a família pelo anonimato e isolamento de um quarto de hotel, que também projeta um ambiente impessoal e alienado; além da ruptura de sua conexão com a natureza — representada pelo vento quente do vale que soprava em sua região, garantindo-lhe "uma fonte de força", e potencializava, de modo simbólico, sua ligação com a comunidade e com a identidade de "homem honesto" (p.16). Essa posição de sujeito entra em crise quando, no nível da ficção, a oposição entre sua identidade "central" ("homem honesto", marido e pai de família) e a radical alteridade de seu pai ("traidor", pai ausente) deixa de ser marcada. O sujeito sofre um deslocamento de sua identidade inicial ao identificar-se com um sistema de valores referentes a uma outra posição de sujeito.

A perda do aspecto acabado e fixo da identidade do protagonista é sugerida na passagem em que ele se aproxima da cosmópole pós-moderna: "Neste momento um certo garoto amedrontado toma o lugar do homem; empurra-o, agarra o volante, curva-se para frente na escuridão, e desce a montanha serpenteante rumo às luzes selvagens de Los

\footnotetext{
${ }^{67}$ A frase original de Baudelaire — "car dans la grandeur de la rêverie, le moi se perd vite!" — aparece no texto "Le 'confiteor' de l'artiste" (2007, p.38).
} 
Angeles" (p.16). ${ }^{68}$ Dessa maneira, podemos dizer que o sujeito experimenta uma multiplicação de identidades: de "homem honesto", ele passa a identificar-se com o pai "traidor"; em seguida, como vimos na passagem reproduzida acima, essa identidade é substituída pela de um jovem ousado e irresponsável, que assume o volante (o controle) do sujeito. A desestabilização da noção prévia de identidade estável que o protagonista vivencia é acompanhada de medo, afinal ele sente-se como um garoto "amedrontado". Byers (1995) associa esse tipo de ansiedade do macho contemporâneo com um sentimento de "pomofobia", isto é, uma resposta desconfortável do sujeito a ameaças impostas pela pósmodernidade como "mudanças na base material e econômica", "o colapso geral das narrativas mestras", bem como o declínio da família nuclear como "o local privilegiado da segurança e do ser do sujeito" (p.5-6), ${ }^{69}$ entre outras. No tocante ao conto de Shepard, as sensações de medo e aversão do protagonista às complexidades instaladas pela pósmodernidade aumentam na mesma proporção que o sujeito vivencia múltiplos deslocamentos de sua identidade, culminando com o abandono da outra mulher.

Ao telefonar para ela, o protagonista identifica-se dizendo "sou eu” (p.17), mas esse "eu" que fala tornou-se muito diferente do sujeito que prometera à esposa não abandoná-la. Neste momento, o sujeito "veste", nos termos de Bauman (2004, p.30), a identidade de "amante".

A posição de sujeito referente ao "homem honesto" que "nunca [...] deixaria a esposa" ficou, de modo literal, para trás. O momento em que essa antiga identidade passa por um descentramento é marcado no conto pela passagem em que o protagonista termina o relacionamento com a esposa, isto é, rompe com a promessa, e deixa o telefone - a última conexão com a antiga "comunidade" - fora do gancho: "Ele tenta ficar observando o telefone pendendo através do espelho retrovisor, mas logo o perde de vista, como alguma pequena parte de si mesmo que foi deixada para trás" (p.15).$^{70}$ Essa "pequena parte", que fica pendente, sem um ponto firme de apoio, sugere a identidade "abandonada" pelo protagonista após complexos processos de fragmentação e o deslocamento do sujeito de sua rede de familiaridade.

\footnotetext{
${ }^{68}$ Now some scared boy take the place of the man; shoves him over, grabs the wheel, hunches forward into the dark, and rides the snaking mountain down into the wild lights of L.A.

${ }^{69}$ changes in the material and economic base [...] the general collapse of master narratives [...] the privileged site of the subject's being and security.

${ }^{70}$ He tries to keep watching the swinging phone in the rearview mirror but loses it quickly, like some small part of himself left behind.
} 
Analisando por esse ângulo, é possível argumentar que o conto de Shepard acompanha a fragmentação do ideal de sujeito centrado, que resulta em uma multiplicidade de identidades temporárias e instáveis. A pergunta — "Para onde eu devo ir?” (p.18) —repetida, ao final do conto, pelo protagonista à outra mulher ressoa como um indício de desorientação. No entanto, isso se deve menos a uma dificuldade de mapear cognitivamente o espaço pósmoderno do que a uma crise de identidade resultante da percepção do sujeito de que o "lugar" na estrutura social que esperava ocupar (ou "suturar-se") não se encontra disponível. Como atesta Bauman, a junção de fragmentos de valores, culturas e relações sociais em um todo coesivo e totalizante, a que damos o nome de identidade, não é mais possível (2004, p.53).

Entretanto, a frustração dessa expectativa sofrida pelo protagonista não gera um grande abalo em seu ânimo. Mesmo em momentos de perdas subjetivas intensas, como no instante em que abandona a rede de familiaridade e penetra na terra devastada de Coalinga, o protagonista parece incapaz de esboçar sentimentos autênticos. Estes são reduzidos a simulacros de sensações como dor - "Ele quer sentir alguma coisa. Pressiona o salto de uma bota com força contra o bico da outra" (p.14) - ou arrependimento: "O cheiro forte e o calor estão fazendo seus olhos lacrimejarem. Ele esfrega a manga da camisa sobre eles e crê por um segundo que está chorando de verdade; acredita que o gesto tem a ver com algum tipo de tristeza" (p.14-15). ${ }^{71}$

A perda da capacidade de expressar sentimentos se dá de maneira crescente na medida em que o protagonista vai deixando de se constituir como um sujeito centrado ou completo. Um mês antes de deixar a esposa, ele ainda era capaz de sentir emoções como fervor e excitação (p.16), bem como medo e repugnância ao chegar a Coalinga (p.11). No entanto, conforme ele se aproxima da metrópole pós-moderna, não há quase nenhuma materialização de sentimentalidade. Durante o telefonema final, por exemplo, quando o protagonista se dá conta de que seus planos foram frustrados, tampouco há comoção por parte do protagonista. Embora se sinta obviamente confuso, ele não reage com a típica violência masculina encontrada no universo ficcional do autor. O narrador limita-se a fornecer uma imagem de queda, que sugere a decepção da personagem, ao comentar que este "ouve o barulho do

\footnotetext{
${ }^{71}$ He wants to feel something. He presses the heel of one boot down hard on the toe of the other. [...] The heavy stench and the heat are making his eyes water. He rubs a sleeve across them and believes for a second that he's actually crying; believes the gesture is about some kind of grief.
} 
homem gordo caindo na piscina lá fora", e em lugar do extravasamento dessa emoção, há apenas silêncio: "Então nada. Uma sirene distante" (p.18). ${ }^{72}$

Em parte, isso se deve ao fato de que as figuras masculinas em Shepard tendem a interpretar até as mais básicas expressões de sentimentos como vulnerabilidade e, dessa forma, seguem o "modelo tradicional de masculinidade emocionalmente reprimida" (McDONOUGH, 2002, p.157), ${ }^{73}$ que os torna incapazes de demonstrar emoções de modos produtivos. Nesse sentido, alguns contos de Shepard, com seus seres ficcionais insensíveis ou apáticos, caracterizados por uma falta de disposição para se comover e articular sentimentos, evocam, em certa medida, as personagens impassíveis ou entediadas de Noll.

Contudo, parece mais acertado ler essa perda da afetividade em geral como mais um efeito da fragmentação do sujeito. Com o colapso da identidade calcada no sujeito centrado, conforme observa Jameson, a materialização dos afetos e emoções é dificultada em razão de que o "próprio problema da expressão está intimamente ligado a uma concepção do sujeito como receptor monádico, cujos sentimentos são expressos através de uma projeção no exterior" (2006, p.42). O relativo apagamento das distinções claras entre o fora representados pelo próprio corpo, pela sociedade, pelo Outro - e o dentro (a crença na existência de um centro nocional, um ego ou um "eu" consciente e único) compromete a externalização desses sentimentos. Isso não equivale a dizer, como já mencionamos, que todo afeto foi apagado da cultura pós-moderna, mas que a materialização dessas emoções, de acordo com Jameson, tende a perder profundidade, passando a figurar apenas como simulacros de imagens superficiais e desistoricizadas (2006, p.38-43). No caso de "Coalinga 1/2 Way", esse dado se reverte não apenas nos traços da metrópole pós-moderna já elencados, mas também na própria construção da narrativa, que é permeada por uma prosa descomplicada, que lembra a impassibilidade minimalista, repleta de sentenças paratáticas sem ligações rigorosas.

O conto não oferece resoluções para o impasse vivenciado pelo protagonista, nem tampouco poderíamos esperar algum tipo de "fechamento" de um texto que, como buscamos salientar, toca em pontos sensíveis da identidade humana. James (2002) observa que em Great Dream of Heaven "não há grandes resoluções, apenas pequenos acontecimentos

\footnotetext{
${ }^{72}$ He hears the loud splash of the fat man hitting the pool outside. Then nothing. A distant siren. Cabe notar que o autor já havia associado crises entre casais à imagem do corpo caindo na água: "No apartamento vizinho, um casal discute / Ele fica dizendo: 'Não, Lorraina, não faça isso!' / Ela fica dizendo: 'Por quê?' / Nadadores caem na piscina lá fora” (SHEPARD, 1982, p.108).

73 traditional model of emotionally locked masculinity [...].
} 
dotados de condensação poética" (p.30). ${ }^{74}$ Nessa mesma coletânea, há uma outra narrativa chamada "Living the Sign", na qual um homem, que, pela carência de nome e de referenciais consistentes de identificação, lembra o protagonista de "Coalinga 1/2 Way". Na história, a personagem busca encontrar sentido para sua própria existência em uma plaqueta com a mensagem "A vida é o que está acontecendo com você enquanto faz planos para alguma outra coisa" (2002a, p.55) ${ }^{75}$ pendurada em um restaurante de fast-food. Dada a situação de completa desorientação e desespero da personagem, poderíamos pensar que se trata de uma continuação de "Coalinga 1⁄2 Way", em que o protagonista, após ser abandonado no hotel em Los Angeles, seguiria viagem, embora não tendo um rumo certo. Não dispomos, no entanto, de dados determinantes quanto à legitimidade dessa relação.

Consideradas essas multiplicações e dissoluções de identidades em textos de Shepard, passamos à verificação de como as indeterminações e os processos de fragmentação da identidade detectáveis em narrativas do autor atuam no sentido de desestabilizar o foco narrativo, recorrendo, para tanto, à análise do conto "Tinnitus".

\subsection{A desestabilização do narrador como centro organizador da percepção}

A subjetividade humana tem merecido intensas reflexões em diversos âmbitos das teorias culturais contemporâneas. Teóricos associados ao pós-modernismo, por exemplo, têm tentado lidar com a problemática do sujeito (McGUIGAN, 1999, p.80-103), dentre outras maneiras, por meio da focalização das práticas de fala, escrita e atuação dos sujeitos, pois, conforme argumenta Huyssen (1986), no texto pós-moderno "importa de fato quem está falando ou escrevendo" (p.213). ${ }^{76}$ Contudo, as teorias pós-modernas tendem a abordar esse sujeito que fala ou escreve como um eu desprovido de interioridade, que, de modo paradoxal, é incapaz de expressão ou emoção, pois, como vimos, o afeto, segundo Jameson (1991), passou por um processo de relativo esmaecimento (2006, p.43), em oposição às noções que

\footnotetext{
${ }^{74}$ there are no great resolutions, just small events rendered with poetic compression.

${ }^{75}$ Life is what's happening to you while you're making plans for something else.

${ }^{76}[. .$.$] it does matter who is speaking or writing.$
} 
conferiam importância e significado ao sujeito como um ente dotado de potência de raciocínio e singularidade de estilo.

Essa preocupação, não apenas no tocante à subjetividade, mas no que diz respeito a muitos outros aspectos da condição pós-moderna, tem sido um traço distintivo de grande parte da atividade artística de Shepard. Apesar de o autor às vezes manter uma postura de resistência à pós-modernidade, seus textos com frequência tendem a promover, conforme Shepard atesta na epígrafe que abre este capítulo, perspectivas fragmentárias e descentradas do eu. Essa noção do eu fraturado, constituído a partir de uma colagem mais ou menos lúdica ou aleatória de fragmentos, é ficcionalizada no conto "Tinnitus" ("Zumbido"), ${ }^{77}$ uma das últimas histórias da coleção Great Dream of Heaven.

Dadas a fragmentação do continuum narrativo bem como a indeterminação contextual, que bloqueiam a totalização das microestruturas textuais, torna-se difícil elaborar um enredo no sentido tradicional. Dessa maneira, uma possível concretização linear da história consistiria no esforço de um homem misterioso no sentido de prolongar a vida de uma égua, campeã dos circuitos de corrida americanos, a fim de salvar a valiosa cria ainda em fase de gestação. Assim como ocorre na recente peça Kicking a Dead Horse (2007), que traz para o palco o cadáver de um cavalo (p.8), o conto coloca em evidência um animal fisicamente fragmentado e quase morto, que, após um acidente, teve uma das pernas amputadas. Ao longo de três dias, o narrador-protagonista remete boletins diários a Palmer, o proprietário do animal, dando conta do estado de saúde da égua, que, apesar das condições críticas, é induzida quimicamente por um grupo de veterinários a parir um potro saudável. Após o parto, a égua é sacrificada e o narrador tem a chance de descansar após o estresse de todo o processo. O texto não deixa claro o motivo pelo qual o narrador precisa trocar de identidades e manter sigilo quanto a sua relação com Palmer. Uma vez que toda a operação conta com o conhecimento expresso da companhia seguradora do animal, não há a configuração de nenhuma tática fraudulenta para obter vantagem de forma ilícita. Dessa maneira, o texto não fornece subsídios para determinar se há alguma fraude subjacente, capaz de motivar o narrador a assumir identidades falsas e mentir.

A história real envolvendo a égua Ruffian, campeã recordista de todos os principais circuitos de corrida americanos nos anos setenta, e as circunstâncias do trágico acidente que

\footnotetext{
77 Este conto também conta com tradução para o português brasileiro (cf. SHEPARD, 2003). Nossa análise baseia-se, entretanto, na versão original em inglês.
} 
destruiu parte dos ligamentos de sua pata dianteira, obrigando seus veterinários a cometerem eutanásia em 1975 (JUSTICE, 2008, p.163), certamente forneceram a base para a composição da personagem fictícia do conto de Shepard. Não há indícios, no entanto, de que Ruffian tenha produzido cria antes de ser sacrificada. Mas a história real desse animal de competição, cuja morte redefiniu os parâmetros de segurança nos dérbis posteriores, sem dúvida inspirou Shepard, que anos depois de escrever "Tinnitus" foi convidado a interpretar Frank Whitely, o treinador do premiado animal, no filme Ruffian (EUA, 2006). O universo das corridas de cavalo sempre exerceu grande influência no imaginário do autor. Em peças como Simpatico e Geography of a Horse Dreamer, os lances bruscos da sorte envolvidos nas apostas milionárias, bem como as trapaças e interesses mobilizados por essa indústria são recriadas pelo dramaturgo como metáforas da condição humana, sobretudo no tocante às disputas arriscadas por poder e fortuna.

Além da perda da integridade física evocada pela alusão à égua Ruffian, o título do texto refere-se a uma das síndromes clínicas mais comuns nos Estados Unidos, que consiste em uma falsa percepção de som em situações em que não há nenhum estímulo acústico. Em outras palavras, trata-se da captação de "um barulho fantasma" que pode ter causas tão diversas quanto a exposição a um alto nível de ruído, bem como a reação a determinados medicamentos e cuja cura depende ainda de maiores estudos (cf. GROOPMAN, 2009, p.42). Quanto ao conto de Shepard, o protagonista sofre de um zumbido constante nos ouvidos, atribuído por ele à exposição prolongada a disparos de arma de fogo em atividade desportiva.

“Tinnitus” apresenta uma tensão inicial em virtude de a história ser contada por um euprotagonista explicitamente não confiável, que, ao longo da narrativa, troca de nomes e mente com extrema facilidade. Apesar de, à primeira vista, a identidade do narrador ser unificada de maneira coerente - o indivíduo confiável e competente, responsável por executar o "serviço sujo" do patrão - a habilidade de mentir do protagonista e as omissões radicais da narrativa atuam no sentido de ressaltar a falsidade de seus construtos e promover uma multiplicação de identidades e perspectivas. Dessa maneira, a suposta "integridade" identitária do sujeito fratura-se em uma sucessão de fragmentos provisórios e indeterminados.

A própria estrutura textual reforça esse sentido de fragmentação ao constituir-se como uma colagem de quatro diferentes segmentos de gravações registradas por uma secretária eletrônica. A disposição do texto na página reforça o sentido de fratura tanto da continuidade narrativa quanto das personagens e experiências ficcionalizadas. Os tópicos desses 
fragmentos textuais dão conta, na maior parte, das atividades suspeitas do protagonista, mas também não deixam de incluir comentários marginais e o fluxo de informações compartilhadas apenas entre o emissor e o suposto receptor.

Não obstante cada uma dessas quatro partes seja precedida por um pequeno cabeçalho contendo data e local em que o narrador alega estar, essas indicações diárias, referentes aos três primeiros dias de fevereiro, são parciais em ambos os sentidos: i) por mencionarem apenas parte das datas, isto é, somente dia e mês, e omitirem o ano em que os eventos relatados ocorreram. Essas indicações falham, portanto, em fornecer um quadro de referência seguro ao leitor. Além disso, é provável que os esforços do narrador em apagar as pistas que o liguem a seu patrão incluam a distorção desses dados de acordo com seus interesses pessoais. Dessa maneira, os cabeçalhos atuam mais no sentido de instaurar dúvidas no leitor do que enraizar os fatos em um padrão realista de causalidade. ii) Há parcialidade também no relato das atividades executadas pelo narrador-protagonista, que, em relatório diário a seu patrão, omite informações importantes entre os registros. $\mathrm{Na}$ primeira mensagem, por exemplo, o narrador menciona que o clima na cidade de Normal, Illinois, está piorando e que há uma nevasca "vindo do Golfo" e trazendo "gelo, neve, granizo, ventos fortes e temperaturas abaixo de zero!” A mensagem seguinte, no entanto, não faz qualquer menção à tempestade de neve "monstruosa" - que estava prestes a irromper como a "ira de Deus" $(2002 \mathrm{a}, \text { p.114 })^{78}$ — nem às circunstâncias que o levaram a viajar para Lexington, no Kentucky. Esse tipo de desmemória ou "amnésia seletiva" do narrador serve para embaralhar ainda mais fatos vivenciados e dados inventados e ressaltar as descontinuidades entre os fragmentos textuais.

Uma das lacunas mais "incômodas" do relato diz respeito a uma personagem cujo papel na vida do narrador parece ter sido relevante, conforme percebemos na seguinte passagem:

Todos aqueles anos atrás, quando eu encontrei a Martha pela primeira vez. Foi bem aqui em Keeneland, 1959. Difícil de acreditar. Você lembra, Palmer - foi você que me desafiou a convidá-la para um highball e um filé. Aquilo foi só o começo. Vinte e dois anos de puro inferno. De fato, eu sinto

\footnotetext{
${ }^{78}[\ldots]$ heading up from the Gulf [...] ice, snow, sleet, driving winds, and minus zero! [...] monstrous [...] the wrath of God.
} 
falta dela, verdade seja dita. Não sei por quê. Talvez seja estrada demais (p.115). ${ }^{79}$

Apesar de esboçada de modo vago, esta personagem é relevante, pois, ao evocá-la, o narrador revela traços de si mesmo e de sua intimidade. Os acontecimentos envolvendo Martha sugerem que houve um vínculo emocional significativo entre ela e o protagonista. Contudo, a atividade de recomposição dessa relação é dificultada pelo fato de o narrador, valendo-se de um conhecimento prévio compartilhado com o destinatário de sua mensagem, não revelar detalhes a respeito da personagem e omitir a maior parte das informações. Dadas as supressões, a passagem reproduzida acima projeta uma mensagem truncada e indeterminada.

Grande parte do truncamento e da fragmentação dessa passagem em particular deve-se às construções em estilo paratático. Ao meramente justapor sentenças declarativas, descrições e imagens carentes de ligações lineares, a narração paratática, como vimos, contribui para fragmentar a história por meio da implementação de visões fraturadas dos acontecimentos. No âmbito do conto "Tinnitus", podemos observar que a maneira como o eu narra os eventos vivenciados por ele na realidade externa é fragmentária e incompleta e, como resultado, o leitor experimenta dificuldades em interagir com informações descontínuas: qual é a relação entre as três personagens (Martha, Palmer e o narrador)? O que aconteceu com ela? Ela morreu ou apenas separou-se do narrador? Por que ele descreve o relacionamento com ela como "puro inferno"? Como a passagem sugere, a relação entre o narrador e Palmer parece ser mais próxima do que a de empregado e empregador. Se o vínculo entre o narrador e Palmer continuou desde "então" (1959) até o presente, o que exatamente aconteceu com Martha durante esse tempo? Por que ela parece ter desaparecido completamente da vida do narrador? Por que o narrador-protagonista parece não ter mais contato com ela?

Não obstante essa passagem envolvendo Martha afigurar-se como um dado corriqueiro, um comentário marginal, o fato de o narrador adotar mentiras e trocas de identidades como prática constante levanta suspeitas. Se presumirmos que Martha faleceu, será que o narrador

\footnotetext{
${ }^{79}$ All those year ago when I first met Martha. It was right here at Keeneland, 1959. Hard to believe. You remember, Palmer - you were the one who dared me to ask her out for a highball and steak. That was just the beginning. Twenty-two years of pure hell. Actually, I miss her, truth be known. I don't know why. Maybe too much road.
} 
tem algum envolvimento em sua morte? Se ele a matou, digamos, para pôr fim aos "vinte e dois anos de puro inferno", seria essa a razão pela qual ele adota nomes falsos? A hipótese de assassinato não deixa de ser consistente com o padrão de abusos cometidos pelas figuras masculinas violentas que tumultuam o universo ficcional de Shepard em contos como "The Phantom Trailer" e "Montana", da coletânea Hawk Moon (1973, p.13,21).

Em decorrência da parcialidade e do ângulo de visão limitado dos sujeitos da enunciação em primeira pessoa de maneira geral, o escrutínio lógico dessas subjetividades com frequência impõe alguns obstáculos. Mas em uma narrativa indeterminada e fragmentária como "Tinnitus", essa perspectiva subjetiva ocasiona dificuldades ainda maiores uma vez que o texto em si incita dúvidas quanto à "veracidade" interna das experiências apresentadas. Esse impasse torna-se mais crítico quando o narrador em primeira pessoa confessa ter se tornado um "mentiroso profissional" (p.117).

A afirmação do protagonista evoca o insolúvel "paradoxo do mentiroso", que é conhecido desde a antiguidade pelas fórmulas "esta frase é falsa" ou "eu estou mentindo agora". Essas afirmações constituem paradoxos, pois não há como determinar se o falante está contando a verdade ou não. Se ele estiver dizendo a verdade no momento em que alega estar contando mentira, ele está mentindo. E se estiver mentindo quando isso é o que realmente está acontecendo, ele deve estar dizendo a verdade (cf. HONDERICH, 2005, p.514). Nesse sentido, a confissão do narrador de "Tinnitus" de que se tornou um "mentiroso professional" e que conta "pequenas lorotas" (p.117) transforma todo o universo ficcional projetado pela narrativa em um território de relatividade, cuja verificação dos dados é sempre adiada. Isso também abre a possibilidade de que, tomados em conjunto, os eventos narrados sejam somente invenções desse "mentiroso profissional".

Além disso, o protagonista adota diferentes nomes ao longo dos três dias. Essa multiplicidade de "disfarces" acaba levando o narrador a equivocar-se diante da profusão de identidades: "eu mesmo me perco" (p.115). ${ }^{80}$ Primeiro, ele afirma se chamar Guy Talmer (p.112); então, assume a identidade de Lyle Maybry e, finalmente, registra-se no hotel com o nome de Filson (p.115). Por essa razão, o leitor nunca tem acesso ao nome, à profissão e à rede de relações sociais do narrador. As camadas de identidades inventadas multiplicam-se, confundindo o narrador e sugerindo que, após essa fragmentação, o eu não voltará a ter uma

\footnotetext{
${ }^{80}$ I lose track myself.
} 
percepção de si mesmo como um todo unificado e completo. Essas oscilações de posições de sujeito ao longo dos quatro textos que compõem o conto não permitem o acesso a uma perspectiva estável dos dados narrados.

O narrador é também versado em práticas ilícitas: ele dirige um veículo com "placas frias", registra-se em motéis com documentos falsos (p.112), utiliza cartões de crédito fraudulentos (p.114), e inventa documentos que jamais existiram: "Eu contei outra pequena lorota [para os veterinários] e disse que tinha autoridade de procurador, mas que havia deixado o documento do tabelião no motel" (p.117). ${ }^{81}$ Dessa maneira, como podemos conhecer os fatos se o narrador, de modo paradoxal, costuma contar "pequenas lorotas" e via de regra é reticente quanto às situações vivenciadas? Como o leitor pode distinguir entre a "verdade" narrativa e as invenções de um narrador assumidamente versátil em fraudar a veracidade das informações constantes de documentos textuais? Se Filson, Lyle e Guy são todas identidades construídas por esse "mentiroso profissional", não há como ter certeza, como no "paradoxo do mentiroso", da "autenticidade" narrativa dos fatos relatados pelo sujeito.

Conforme observa Hutcheon (1988), a analogia entre o sujeito da enunciação e a subjetividade da narrativa nunca foi uma relação estável devido ao fato de que, sobretudo em textos pós-modernos, essas subjetividades que tomam a palavra são com frequência sujeitos "manipuladores de um modo deliberado e explícito", que se fragmentam em "uma grande quantidade de vozes" ao invés de se constituírem como narradores coerentes, unificados tal qual os inscritos pelos romances realistas tradicionais (p.158-161). ${ }^{82}$ Nessa mesma linha de raciocínio, Skrainka (1993) argumenta que nos textos pós-modernos, "o narrador onisciente e confiável não existe; ele dá lugar a uma sucessão de narradores duvidosos que se contradizem" (p.5). ${ }^{83}$

Em um conto pós-moderno como "Tinnitus", o sujeito responsável pela articulação da narrativa não se encaixa, por exemplo, no modelo desenvolvido por Norman Friedman para o "eu como protagonista" uma vez que a definição atribuída pelo teórico a esse tipo de narrador é baseada em um ideal tradicional de sujeito centrado. Para Friedman, o "eu como protagonista" é concebido como um centro ou um olho posicionado acima da esfera de ação,

\footnotetext{
${ }^{81}$ I told another little fib and claimed I had power of attorney but had left the notary sheet back at the motel.

${ }^{82}$ overt, deliberately manipulative [...] myriad of voices.

${ }^{83}$ le narrateur omniscient et credible n'existe pas; il fait place à une succession de narrateurs douteux qui se contradisent. Outra referência ao narrador "infiel" encontra-se em Carvalho (2005, p.21-33).
} 
capaz de organizar pensamentos, sentimentos e percepções de acordo com uma "perspectiva [que] é a do centro fixo" $(1975, \mathrm{p} .152){ }^{84}$

O tipo de subjetividade indeterminada e fragmentária detectado em "Tinnitus" pode ser lido como uma manifestação ficcional do sujeito pós-moderno, que, segundo Hall, "não possui uma identidade fixa, essencial ou permanente", isto é, de um sujeito que "assume diferentes identidades em momentos distintos, identidades que não são unificadas em torno de um 'eu' coerente" (1992, p.277). ${ }^{85}$ As constantes trocas de identidades performatizadas pelo sujeito-protagonista de "Tinnitus", conforme as circunstâncias, são disfarces que objetivam apagar traços de uma identidade "original" ou "verdadeira". Elas acabam causando uma crise de identidade no sujeito, que, como vimos, tem dificuldades em monitorar toda a multiplicidade de seus próprios construtos.

Dessa maneira, o conto de Shepard realiza uma simulação ficcional de uma relativa perda de controle do narrador no tocante à sua própria narração. Indícios dessa "falta" de domínio sobre a construção da intriga adquirem materialidade sob a forma de dados fragmentários como personagens e situações "incompletas", que não recebem um tratamento totalizante. A identificação do narrador como mentiroso e falsificador desestabilizam as expectativas do leitor de encontrar uma mediação minimamente confiável das experiências narradas (cf. SOBREIRA, 2007a, p.173-179). Ao invés da visão tradicional do narrador como centro organizador da percepção, o conto de Shepard projeta um eu "confuso", cujas tentativas de comunicar sentidos para o leitor tendem a ser indeterminadas, fragmentárias e marcadas por uma "aparente distorção da experiência", semelhante à identificada por Wetzsteon na fase inicial da produção dramática de Shepard (2006, p.4).

A dissolução do "eu" como um sujeito autossuficiente e em pleno controle é também sugerida de maneira metafórica pelas imagens de deterioração da saúde física e mental do narrador: sua estrutura corporal é abalada por problemas em sua "velha coluna" e por um "zumbido crônico em [seu] ouvido esquerdo", ${ }^{86}$ que em geral interfere na clareza de seu raciocínio: "Eu não conseguia me concentrar na linha reta e estreita [da estrada]" (p.112).

\footnotetext{
${ }_{85}^{84}$ angle of view is that of the fixed center.

${ }^{85}$ conceptualized as having no fixed, essential or permanent identity [...] assumes different identities at different times, identities which are not unified around a coherent 'self'.

${ }^{86}$ old spine [...] chronic ringing in my left ear [...] I couldn't keep my mind on the straight and narrow.
} 
Além disso, o fato de que ele vive sob circunstâncias bastante negativas tais como, por exemplo, a constante ameaça (seja real ou imaginária) de perseguição e sua inabilidade de se conectar com outras pessoas, podem ser lidas como impasses que tornam difícil para o sujeito obter o que Hall chama de "ancoragem estável no mundo social" (1992, p.274) ${ }^{87}$ e, dessa maneira, estabilizar suas identidades na medida do possível.

As constantes referências a quartos de motel e estradas solitárias, por suas evocações de impessoalidade e solidão, também sugerem o anonimato e o isolamento do narrador em um mundo caracterizado por ele mesmo como "realmente hostil" (p.113). Esse sentido de deslocamento é também reforçado pela descrição dos vapores sobre o pavimento da rodovia e de como eles lembram uma paisagem do planeta Marte (p.112-113). O aspecto nebuloso dessa imagem e a referência à paisagem fluida e alienígena reforçam o desenraizamento do narrador e sua dissociação de vínculos sociais e interpessoais consistentes.

O estado problemático do protagonista, que vive profundamente imerso na "realidade da dor" (p.114), em vez de focalizar os objetos do alto como o eu-protagonista de Friedman, bem como o caráter descontínuo e indeterminado da narrativa que ele constrói e a linguagem contraditória que utiliza para se constituir como um sujeito falante, contribuem para desestabilizar a posição de centro nocional do sujeito da enunciação. Esse deslocamento do narrador da antiga posição centrada de produtor de sentido, cuja responsabilidade orientavase no sentido de organizar elementos narrativos por meio da mediação de experiências e informações, relaciona-se ao processo de dilaceramento e fragmentação do sujeito narrador detectado, como notamos, também em narrativas de João Gilberto Noll.

Quanto ao conto "Tinnitus", a atividade de enviar mensagens telefônicas fragmentadas que distingue este sujeito autoral inafiançável dificulta o acesso a um eu coerente ou mesmo “integral”. Em vez disso, temos uma subjetividade contextual e temporária, cuja prosa fragmentária e indeterminada falha em compor uma visão totalizante. Essa simulação de "falha" afeta não só os fios narrativos, que no caso de "Tinnitus" parecem engendrados de maneira precária e incompleta, mas também o próprio eu responsável pela narração dos acontecimentos. Ao afirmar que até ele perdeu o controle sobre seus múltiplos construtos identitários (2002a, p.115), o narrador sugere de maneira indireta que a percepção de quem ele mesmo é - isto é, qual seu "verdadeiro" eu — sofreu um processo de dissolução,

\footnotetext{
${ }^{87}$ stable anchorage in the social world.
} 
tornando-se incerta, indeterminada. A frequente adoção de diferentes "papéis" e performances realizadas pelas personagens dramáticas de Shepard ocasionam a emergência, de acordo com Wetzsteon, do tema da "identidade incerta" $(2006, \mathrm{p} .8) .{ }^{88}$ No que se refere a alguns dos contos publicados em Great Dream of Heaven e, em especial, a "Tinnitus", podese afirmar que as posições de sujeito também são acometidas pela incerteza, bem como o universo ficcional, que embora apresente traços de familiaridade, projeta-se ao mesmo tempo como uma campo de ação indeterminado (coordenadas parciais; episódios fragmentários) e estranho (experimentos cruéis com animais; paisagem alienígena). Esse conjunto de indeterminações evoca os questionamentos ontológicos apontados por Dick Higgins, em $A$ Dialectic of Centuries: Notes Toward a Theory of the New Arts (1978), como prototípicos da ficção pós-moderna: "Que mundo é este? O que se deve fazer nele? Qual dos meus eus deve fazê-lo?" (p.101, grifo nosso). ${ }^{89}$

Todos esses questionamentos e dúvidas envolvendo o sujeito ficcional, marcados pelo predomínio de traços confusos, perspectivas fragmentárias e comentários que desabonam de maneira explícita a credibilidade do próprio narrador contribuem para a instauração de incertezas quanto à veracidade interna das experiências relatadas e da estabilidade do próprio lócus da enunciação. Desse modo, em vez do "sonho vívido e contínuo", proposto por Gardner (2004, p.223), o leitor confronta-se com um universo ficcional contingente, construído por sujeitos fraturados de maneira irreversível. A partir dessas considerações, cabe retomar, no que segue, alguns tópicos principais a fim de tecer algumas conclusões.

\footnotetext{
${ }^{88}$ uncertain identity.

${ }^{89}$ Which world is this? What is to be done in it? Which of my selves is to do it?
} 


\section{CONSIDERAÇÕES FINAIS}

O percurso de leitura dos livros Mínimos, múltiplos, comuns, de João Gilberto Noll, e Great Dream of Heaven, de Sam Shepard, realizado ao longo deste trabalho, examina alguns direcionamentos recentes no gênero conto, sobretudo o de orientação minimalista e pósmoderna, a partir de um estudo de aspectos dominantes como indeterminações e fragmentações. Podemos detectar alguns desses direcionamentos alternativos ao compararmos os preceitos normativos rígidos, que dominaram o gosto e as práticas ficcionais vigentes tanto em contos tradicionais como em textos modernos, com formas ficcionais mais recentes, nas quais alguns daqueles preceitos estéticos fluidificam-se em favor de perspectivas mais abertas ${ }^{1}$ e fragmentárias.

Quando examinamos contos de Noll e Shepard (bem como textos de Jesse Ball e, até certa medida, de Raymond Carver) à luz dos preceitos tradicionais do gênero conto, segundo os quais, por exemplo, "a imaginação [do contista] jamais se perde no vago, ao contrário, prende-se plasticamente à realidade concreta" (MOISÉS, 1975, p.127, grifos nossos), percebemos que os textos dos autores acima referidos provocam uma relativa ruptura com tais princípios. Contrariamente às regras dominantes nos contos típicos, há um investimento maior, em textos dos autores associados ao pós-modernismo, em favor não apenas da ambiguidade e da vagueza de ideias e situações, mas das indeterminações narrativas, que podem até mesmo bloquear o processamento cognitivo de dados do próprio enredo, dificultando a interação com os elementos da(s) "realidade(s)" concretizada(s) nesses textos.

\footnotetext{
${ }^{1}$ A noção de "abertura" aqui é empregada em consonância com Eco (1969), segundo o qual, a ideia de "obra aberta" aplica-se a diversos produtos artísticos de diferentes épocas, cuja estruturação favoreça não apenas sentidos vagos, significados imprecisos, ambiguidades e indefinições, mas também traços como descontinuidades, possibilidades de diferentes combinações e configurações materiais da obra etc. De maneira geral, Eco considera "abertas" as obras (sejam musicais, literárias, pictóricas, visuais etc.) que abram campos de possibilidade, virtualmente inesgotáveis, para a intervenção consciente do leitor, sob a forma de aspectos materiais como, por exemplo, a utilização lúdica de planos transponíveis ou estruturas dinâmicas. Essas obras caracterizam-se pelo movimento, pela contínua reversibilidade de valores e certezas, pela carência de soluções, pela ausência de pontos privilegiados e pela admissão de todas as perspectivas como igualmente válidas e ricas de possibilidades (p.37-66).
} 
Outra importante dominante do conto tradicional — sua "unidade de ação" ou "unilinearidade" (CORONADO, 1969-1970, p.35), isto é, sua necessidade de desenvolver uma "progressão ininterrupta" de "segmentos consecutivos" (Id., ibid., p.33) — parece deslocada, ao menos nos textos dos autores referidos acima, para segundo plano. Em alguns contos contemporâneos de Noll, por exemplo, os acontecimentos não apresentam um padrão linear de progressão, pois a supressão ou rarefação de coordenadas espaçotemporais, bem como as construções não seletivas promovidas pelos processos paratáticos fragmentam as ações em parcelas mínimas ou impedem a concatenação e a unificação dos elementos díspares de que são feitas as experiências narrativizadas. No caso de "Tinnitus", de Shepard, a narrativa perde a unidade por meio da inserção de "blocos" textuais relativamente independentes, cujos elementos de sequencialidade são fragmentados.

Outro princípio marcante do conto tradicional refere-se à geração de interesse. Como sabemos, o contista típico deveria produzir algum tipo de tensão narrativa, que levasse a um clímax e a um desenlace, em geral, surpreendente. Um conto sem essa progressão tensiva seria ineficaz, conforme observa Coronado (1969-1970): "ausência de gradação tensiva equivale a carência de tensão narrativa, e sem esta, o conto resulta desinteressante, conseguindo dificilmente prender a curiosidade do leitor e despertar no seu ânimo o prazer do belo narrativo" (p.36, grifos nossos). As práticas mais recentes, que associamos ao pósmodernismo, do gênero conto, entretanto, costumam não apenas obliterar os conceitos de linearidade e progressão implicadas na noção de "gradação", como também conferir uma ênfase cada vez menor a esquemas de ordem tensiva com o intuito de produzir interesse. Como analisamos anteriormente, alguns dos textos produzidos por Sam Shepard e João Gilberto Noll orientam-se mais em favor de uma escrita monótona, impassível, repetitiva ou desprovida de gradação tensiva. Os resultados são histórias "tediosas" (cf. JAMESON, 2006, p.95), que parecem "evaporar" da página, isto é, textos que "falham" em insinuar-se na mente do leitor e inspirar-lhe interesse e curiosidade (cf. KAKUTANI, 2002, p.7).

Pode-se perceber uma mudança de dominante até mesmo em relação aos princípios normativos desenvolvidos por contistas e teóricos associados às correntes modernistas, conforme abordado ao longo da seção 1.2 deste trabalho. Ao contrário das recomendações de Tchekhov quanto à necessidade de direcionar implicitamente a interpretação do leitor (BLAISDELL, 2004), alguns dos contos de Shepard e, sobretudo, de Noll projetam enredos marcados pela intensificação de "porosidades" e incompletudes narrativas, que não apenas 
"abrem" (no sentido atribuído por Umberto Eco) o texto, mas muitas vezes frustram a própria concretização dos esquemas narrativos.

Como sabemos, "a modernidade é a época para a qual o ser moderno se torna valor, ou, melhor, $o$ valor fundamental, a que todos os demais são referidos" (VATTIMO, 2007, p.97). É possível abstrair dessa orientação quanto ao "valor do novo, ou da novidade como valor", que um traço comum às muitas correntes implicadas na formação de movimentos modernistas refere-se à inspiração radicalmente antipassadista (Id., ibid., p.97). Nesse contexto, várias vertentes do conto moderno primavam, como mencionamos, pela tentativa de forjar escritas singulares, dotadas de estilos não experimentados anteriormente. A emergência do pós-modernismo, entretanto, rompe com as práticas modernas que enformam a lógica do avanço progressivo rumo à constante obtenção do novum como valor maior. Nesse sentido, Vattimo (2007) conclui:

Da arquitetura ao romance, da poesia às artes figurativas, o pós-moderno mostra como sua característica mais comum e mais imponente o esforço para escapar à lógica da superação, do desenvolvimento e da inovação (p.104).

Assim, o princípio radicalmente antipassadista, defendido desde os manifestos de vanguarda e assumido por muitos artistas modernos, passa a ser transgredido por autores contemporâneos. No caso de Noll e Shepard, essa transgressão materializa-se sob a forma de pastiches (JAMESON, 2006, p.44-45) ou empréstimos momentâneos de linguagens e outros elementos próprios a estilos "mortos" do passado como os traços góticos, surrealistas e até fantásticos, que são incorporados, como salientamos na seção 1.3.3, à trama narrativa de seus contos. A partir dessa técnica, o passado é "parasitado" (ANDERSON, 1998, p.60) e a busca da superação artística por meio do desenvolvimento de um estilo único é deslocada para um plano secundário em favor de operações pós-modernas básicas, que, segundo Calabrese (1999), consistem na "reelaboração, no pastiche, na desmontagem do patrimônio literário (ou cinematográfico) imediatamente precedente" (p.28). ${ }^{2}$

\footnotetext{
${ }^{2}$ reelaboración, en el pastiche, en la desarmadura del patrimonio literario (o cinematografico) inmediatamente precedente.
} 
Além disso, esses textos também subvertem a teoria da ponta do iceberg, defendida por Hemingway. Nela, o autor americano sugere, como referimos, uma divisão entre a parte superficial e a parte submersa do conto, sendo que a primeira representa aquilo que o texto diz, e a segunda, as informações omitidas pelo texto. O contista, ao elaborar o que é dito, deve ter em mente, de maneira muito clara, quais são os traços eventualmente omitidos pela história (parte submersa). O autor pode então sugerir esses elementos não ditos, de maneira tácita, ao leitor. Caso o contista não tenha domínio sobre esse todo (dito + não dito), podemse criar lacunas na história (RULAND \& BRADBURY, 1991, p.303-305; MORELAND, 2000). Os contos focalizados neste trabalho, no entanto, atuam mais no sentido de incorporar elementos espontâneos e não seletivos, inclusive adotando a indeterminação como sensação mestra na escrita, em detrimento de uma produção cujos aspectos omitidos sejam previamente concebidos com meticulosa atenção. Nesses contos, que associamos ao pósmodernismo, o todo tende a escapar, pois a "soma" de ambas as partes, como propõe Hemingway, não garante completude, mas apenas mais parcialidade e fragmentação.

Dessa forma, a ênfase maior em aspectos como indeterminações, incompletudes, fragmentações e pastiches - em detrimento de valores do conto tradicional e moderno como clareza, inovação estilística, unidade e totalização — constitui um indicativo de um contexto atual propenso à mudança de dominante. Por essa razão, e levando em consideração o arcabouço teórico utilizado, podemos observar a possível emergência de uma contística recente mais afeita aos posicionamentos teóricos associados ao pós-modernismo. Essa observação não assinala, entretanto, o término de práticas residuais mais orientadas aos esquemas familiares propostos pelos contos típicos, mas indica direcionamentos distintos para o gênero no contexto pós-moderno.

As breves narrativas de ambos os autores instalam e subvertem as expectativas geradas pelo conto, gênero tradicionalmente regido por princípios rigorosos de estruturação e desenvolvimento, a partir de profundas omissões de dados narrativos e rupturas tanto com a "informatividade" do texto como com a ideia de sequencialidade lógica e causalidade natural.

Nesse sentido, a interação do leitor também é problematizada uma vez que este experimenta dificuldades em "inteirar" (no sentido de tornar inteiro, completar ou preencher) as proposições textuais, pois os contos pós-modernos contemplados por este trabalho oferecem textualizações lacunares e fragmentárias, além de processos paratáticos, que se traduzem em imagens e outras proposições carentes de ligações rigorosas. Por essa razão, 
torna-se um desafio também "inteirar-se" (no sentido de tornar-se ciente ou informar-se) dos dados narrativos, pois o narrar, nesses textos, tende a não "dar a saber" informações contextuais basilares envolvendo personagens e circunstâncias, bem como a frustrar o processamento cognitivo das proposições narrativas por meio da inserção deliberada de elementos indeterminados e minimalistas, que, como sugere Jameson, estão associados a uma certa "recusa da plenitude" textual (2006, p.262). Dessa maneira, as indeterminações e as fragmentações, dois amplos processos narrativos, que, por sua vez, envolvem uma série de outros procedimentos ficcionais, atuam no sentido de deter o impulso de totalizar (cf. HUTCHEON, 1988, p.ix; RINCÓN, 1995, p.123), isto é, de exercer controle ou unificar elementos e materiais díspares em nome de um sistema de representação positivista ou humanista pleno ou unificado.

A recorrência desses procedimentos ficcionais nas narrativas investigadas neste trabalho colabora para a produção de ao menos dois efeitos básicos de sentido, que, embora distintos, são corolários de uma visão de mundo pós-moderna: primeiramente, os expedientes de indeterminação e fragmentação podem ocasionar bloqueios parciais ou totais do processamento cognitivo da trama narrativa - traço indicativo de uma ênfase maior na dominante ontológica em detrimento da polaridade epistemológica. Em segundo lugar, essas construções textuais de universos imaginários, que incluem personagens, situações, referências espaçotemporais, bem como narrações fragmentárias e indeterminadas, sugerem a materialização de níveis significativos de disjunções e instabilidades implicadas no próprio processo de filtragem das experiências pelo sujeito narrador.

Podemos inferir, a partir disso, que as narrativas de ambos os autores "encenam" na própria linguagem em prosa as dificuldades envolvidas nas tentativas de conferir unidade, criar relações nexivas, ou dar sentido (em termos de desenvolvimento elucidativo do relato) não apenas às vivências fragmentárias das personagens e do próprio eu narrador, mas também às próprias narrativas lacunares que buscam representá-las. Nesse sentido, Simon (2007), em "O conto e o pós-modernismo: recorte, velocidade e intensidade", observa o seguinte: "o caráter fragmentário transcende o conto e caracteriza também o mundo aí representado, igualmente fragmentado" (p.137). As narrativas de Noll, por exemplo, distinguem-se pela "impossibilidade de organizar o vivido numa narrativa coerente e significativa. Tudo flui, mas nada muda, a experiência nunca se torna um saber narrável” (KLINGER, 2007, p.57). Nesse sentido, emprestamos a observação de Jameson, feita em contexto diferente, porém 
análogo, segundo a qual, em tempos pós-modernos, "parecemos cada vez mais incapazes de produzir representações de nossa própria experiência corrente" (2006, p.48).

As percepções dessa incapacidade indiciam, como observamos, uma deficiência de integralização de ordem mais geral, inscrita na figura do sujeito pós-moderno, cujas identidades não comportam fechamentos coerentes, nem tampouco unidade de pensamento ou ação. Dessa maneira, percebemos as narrações indeterminadas e fragmentárias que contemplamos neste estudo como aspectos da produção discursiva ficcional de sujeitos também fragmentados (isto é, não unificados em torno de algum eixo significativo) e marcados por traços muitas vezes não determináveis em termos de identidade, sexualidade ou aderência a redes consistentes de familiaridade.

Conforme notamos, a incidência dessas indeterminações sobre a subjetividade do ser humano, sobretudo do indivíduo do sexo masculino no contexto da contemporaneidade, tende a materializar-se de modo recorrente nas coletâneas de ambos os autores. Além de compartilharem de dificuldades gerais quanto ao estabelecimento de ancoragens estáveis na esfera social, as personagens criadas pelos escritores em pauta têm em comum uma forte atração por vastos espaços abertos, pelos quais empreendem suas errâncias, sem nunca se fixarem. Esses cenários áridos e solitários costumam compor paisagens emocionais, cujo papel consiste em sugerir profundas crises identitárias dos sujeitos ficcionais.

E embora a produção literária de João Gilberto Noll e Sam Shepard seja marcada por diferenças e especificidades, podemos concluir que os dois autores distinguem-se pelas tentativas de plasmar diferentes noções do sujeito pós-moderno, seja por meio da criação de um eu em trânsito ou por meio de processos de multiplicação e dissolução de identidades. Nesse processo, não apenas as noções clássicas de sujeito como ente unificado são eclipsadas, mas os próprios contornos paradigmáticos de masculinidade fluidificam-se, seja pelo viés da diversidade de práticas sexuais ou pelo enfraquecimento físico, psíquico e moral do patriarcado hegemônico. Assim, a fragmentação das estruturas estáveis do ser não precisa ser lida necessariamente de maneira catastrófica - afinal, fratura indica perda da unidade, não destruição - mas como manifestações artísticas de possibilidades e chance positiva de questionar valores e certezas. 


\section{REFERÊNCIAS BIBLIOGRÁFICAS}

ABBOTSON, Susan C. W. Sam Shepard: A Bibliographic Essay and Production Overview. In: ROUdAnÉ, Matthew (Ed.). The Cambridge Companion to Sam Shepard. Cambridge: Cambridge University Press, 2002, p.292-310.

ABRAMS, Linsey. A Maximalist Novelist Looks at Some Minimalist Fiction. Mississippi Review, v. 40-41, n. 1, p.24-30, Winter 1985.

ADLER, Thomas P. Repetition and Regression in Curse of the Starving Class and Buried Child. In: ROUDANÉ, Matthew (Ed.). The Cambridge Companion to Sam Shepard. Cambridge: Cambridge University Press, 2002, p.111-122.

ADORNO, Theodor W. Parataxis. In: Notas de literatura. Tradução de Celeste Aída

Galeão e Idalina Azevedo da Silva. Rio de Janeiro: Tempo Brasileiro, 1973.

AGUIAR E SILVA, Vitor Manuel de. Teoria da literatura. 3.ed. Coimbra: Almedina, 1973.

ANDERSON, Perry. The Origins of Postmodernity. London and New York: Verso, 1998.

ANDERSON, Quentin. The Emergence of Modernism. In: ELLIOTT, Emory (Ed.) Columbia

Literary History of the United States. New York: Columbia University Press, 1988, p.695-714.

ANDERSON, Sherwood. Winesburg, Ohio. London: Penguin, 1976.

ANDRADE, Mário de. Contos e contistas. In: O empalhador de passarinhos. 4.ed. Belo Horizonte: Itatiaia, 2002, p.9-12.

Contos novos. Belo Horizonte: Itatiaia, 1999.

ARISTÓTELES. Arte retórica e arte poética. Tradução de Antônio Pinto de Carvalho. São Paulo: Difel, 1959

ARONOWITZ, Stanley. Reflections on Identity. In: RAJCHMAN, John (Ed.) The Identity in Question. New York and London: Routledge, 1995, p.111-127.

ATHERTON, Mike. Great Dream of Heaven by Sam Shepard. Disponível em: <http:// 
www.bookslut.com/fiction/2002_09_000074.php> Acesso: 01 nov. 2004.

ATHEY, David. Great Dream of Heaven by Sam Shepard. Harvard Review, v. 1, n. 25, p.227228, Fall 2003.

AUERBACH, Doris. Who Was Icarus's Mother? The Powerless Mother Figures in the Plays of Sam Shepard. In: KING, Kimball. Sam Shepard: A Casebook. New York and London: Garland, 1988, p.52-64.

AUERBACH, Erich. Mimesis: A representação da realidade na literatura ocidental. Tradução de George Bernard Sperber e Suzi Frankl Sperber. São Paulo: Perspectiva, 2004.

AUSLANDER, Philip. Postmodernism and Performance. In: Connor, Steven (Ed.) The Cambridge Companion to Postmodernism. Cambridge: Cambridge University Press, 2004, p.97-115.

AVELAR, Idelber. Bildungsroman at a Standstill, or the Weakening of Storytelling. In:

The Untimely Present: Postdictatorial Latin American Fiction and the Task of Mourning. Durbam and London: Duke University Press, 1999, p.186-209.

BALDARO, Frank J. Sam Shepard's New Collection of Stories. Rev. Great Dream of Heaven. American Theatre. New York, p.81-82, nov. 2002.

BALL, Jesse. Plainface. The Paris Review, New York, v. 51, n. 188, p.102-131, Spr. 2009.

BARTH, John. A Few Words About Minimalism. In: Further Fridays: Essays, Lectures, and Other Nonfiction. Boston: Little, 1995. 64-74.

BARTHES, Roland. Image Music Text. London: Fontana Press, 1977.

BAUDELAIRE, Charles. Pequenos poemas em prosa (O spleen de Paris). Tradução de Dorothée de Bruchard. São Paulo: Hedra, 2007.

BAUDRILLARD, Jean. The Evil Demon of Images and The Precession of Simulacra. In: DOCHERTY, Thomas (Ed.). Postmodernism: A Reader. New York: Columbia University Press, 1993, p.194-199.

BAUMAN, Zygmunt. Identity. Cambridge: Polity, 2004.

BEAUVOIR, Simone de. The Second Sex. New York: Vintage, 1989. 
BECKETT, Samuel. Waiting For Godot: A Tragicomedy in Two Acts. New York: Grove Press, 1982.

BENNETT, Andrew. Hating Katherine Mansfield. Journal of Theoretical Humanities. New Jersey, v. 7, n. 3, p.3-16, dec. 2002.

BEST, Steven; KELLNER, Douglas. Postmodern Theory: Critical Interrogations. New York: Guilford, 1991.

BIGSBY, Christopher. Born Injured: The Theatre of Sam Shepard. In: ROUDANÉ, Matthew (Ed.). The Cambridge Companion to Sam Shepard. Cambridge: Cambridge University Press, 2002, p.7-33.

BIGUENET, John. Notes of a Disaffected Reader: The Origins of Minimalism. Mississippi Review, v. 40-41, n. 1, p.40-45, winter 1985.

BLAISDELL, Bob. A Few Words of Advice From Anton Chekhov. Writer, v. 117, n. 9, Sept. 2004.

BORGES, Jorge Luis. Del rigor en la ciencia. In: Obras completas. v. 2: 1952-1972.

Buenos Aires: Emecé, 1989.

BOSI, Alfredo. História concisa da literatura brasileira. 36.ed. São Paulo: Cultrix, 1994.

BOTTOMS, Stephen J. Shepard and Off-Off-Broadway: The Unseen Hand of Theatre Genesis.

In: ROUDAnÉ, Matthew (Ed.). The Cambridge Companion to Sam Shepard. Cambridge: Cambridge University Press, 2002, p.34-63.

BRADLEY, Fiona. Surrealismo. Tradução de Sérgio Alcides. São Paulo: Cosac Naify, 2001.

BRASIL, Ubiratan. Os instantes ficcionais de João Gilberto Noll. O Estado de S. Paulo.

Caderno 2, 27 de julho de 2003. Disponível em: <http://www.joaogilbertonoll .com.br/estudos.html> Acesso em: 13 mar 2004.

BRAUTIGAN, Richard. Revenge of the Lawn: Stories 1962-1970. New York: Simon, 1971.

BRAYNER, Aquiles Ratti Alencar. Body, Corporeal Perception and Aesthetic Experience in the Work of João Gilberto Noll. 2006. 256 f. Tese (Doutorado) - King's College, University of London, 2006. 
BROOKS, Xan. Nowhere To Hide: Sam Shepard's Portrait of America in Stasis. Rev. Great Dream of Heaven. The Guardian. London, 23 Nov. 2002. Features \& Reviews, p.26.

BROWN, Suzanne Hunter. Discourse Analysis and the Short Story. In: LOHAFER, Susan; CLAREY, Jo Ellyn (Ed.). Short Story at a Crossroads. Baton Rouge, LA and London: Louisiana State University Press, 1989, p.217-248.

BUNNIN, Nicholas; YU, Jiyuan. The Blackwell Dictionary of Western Philosophy. Oxford: Blackwell, 2004.

BUTLER, Christopher. Postmodernism: A Very Short Introduction. Oxford and New York: Oxford University Press, 2002.

BYERS, Thomas B. Terminating the Postmodern: Masculinity and Pomophobia. Modern Fiction Studies, v. 41, n. 1, p.5-33, Spr. 1995.

CALABRESE, Omar. La era neobarroca. Traducción de Anna Giordano. 3.ed. Madrid: Cátedra, 1999.

CARELLI, Wagner. Um painel minimalista da criação. In: NOLL, João Gilberto. Mínimos, múltiplos, comuns. São Paulo: Francis, 2003, p.19-22.

CARVALHO, Bernardo. Em cenas, Sam Shepard idealiza o oeste e o real. Folha de S. Paulo, São Paulo, 15 nov. 2003. Folha Ilustrada, p.7.

CARVER, Raymond. De que falamos quando falamos de amor. 3.ed. Tradução de Carlos Santos. Lisboa: Teorema, 2001.

What We Talk About When We Talk About Love. New York: Vintage, 1989.

CASTRO, Manuel Antônio de. O narrador e a obra: a linguagem como medida. In: MARCHEZAN, Luiz Gonzaga; TELAROLLI, Sylvia (Orgs.). Cenas literárias: a narrativa em foco. São Paulo: Cultura Acadêmica, 2002, p.57-74.

CLUM, John M. The Classic Western and Sam Shepard's Family Sagas. In: ROUDANÉ, Matthew (Ed.). The Cambridge Companion to Sam Shepard. Cambridge: Cambridge University Press, 2002, p.171-188.

COHN, Ruby. Twentieth-Century Drama. In: ELLIOTT, Emory (Ed.) Columbia Literary 
History of the United States. New York: Columbia University Press, 1988, p.1101-1125.

COLTRANE, Scott. Family Man: Fatherhood, Housework, and Gender Equity. New York: Oxford University Press, 1996.

CONNOR, Steven. Postmodernism and Literature. In: (Ed.). The Cambridge

Companion to Postmodernism. Cambridge: Cambridge University Press, 2004, p.62-81.

CORONADO, Guillermo de la Cruz. Teoria do conto. Estudos Anglo-Hispânicos, n.2-3, p.1545, 1969-1970.

CORTÁZAR, Julio. Valise de Cronópio. Tradução de Davi Arrigucci Júnior. São Paulo: Perspectiva, 1974.

CUDDON, J. A. The Penguin Dictionary of Literary Terms and Literary Theory. London: Penguin, 1999.

CURRIE, Peter. The Eccentric Self: Anti-Characterization and the Problem of the Subject in American Postmodernist Fiction. In: BRADBURY, Malcolm; RO, Sigmund (Eds.). Contemporary American Fiction. Stratford-upon-Avon Studies. London: Edward Arnold, 1987, p.53-69.

DEMASTES, William W. Understanding Sam Shepard's Realism. Comparative Drama, v. 21, n. 3, p.229-248, Fall 1987.

DeROSE, David J. Sam Shepard. New York: Twayne, 1992.

DOCHERTY, Thomas (Ed.). Postmodernism: A Reader. New York: Columbia University Press, 1993.

DRABBLE, Margaret. The Gates of Ivory. New York: Viking, 1992.

DURÃO, Fábio. Sobre a ficção suprema: prolegômeno e contra-exemplo. In: FERNANDES, Maria Lúcia Outeiro et al. (Orgs.). Estrelas extremas: ensaios sobre poesias e poetas. São Paulo: Cultura Acadêmica, 2006, p.41-59.

EAgleton, Terry. How To Read A Poem. Oxford: Blackwell, 2007. Literary Theory: An Introduction. 2.ed. Oxford: Blackwell, 1996.

ECO, Umberto. Obra aberta: forma e indeterminação nas poéticas contemporâneas. 
Tradução de Giovanni Cutolo. São Paulo: Perspectiva, 1969.

ELIOT, T.S. The Waste Land. In: WILKIE, Brian; HURT, James (Orgs.) Literature of the

Western World, v.II, Neoclassicism Through the Modern Period. New York: Macmillan, 1984, p.1894-1909.

Hamlet and His Problems. In: KERMODE, Frank. Selected Prose of T.S. Eliot. New York: Harvest, 1975, p.37-49.

ELLIS, James. Sherwood Anderson's Fear of Sexuality: Horses, Men, and Homosexuality. Studies in Short Fiction. Newberry, SC, v. 1, n. 30, p.595-601, 1993.

FEDERMAN, Raymond. A Short Note On Minimalism. Mississippi Review, v. 40-41, n. 1, p.57, winter 1985 .

FERGUSON, Suzanne. The Rise of the Short Story in the Hierarchy of Genres. In: LOHAFER, Susan; CLAREY, Jo Ellyn (Ed.). Short Story Theory at a Crossroads. Baton Rouge and London: Louisiana State University Press, 1989, p.176-192.

FRANCO, Renato Bueno. O dilaceramento social do narrador: sobre Quatro-olhos, de R. Pompeu. In: DEL VECCHIO, Angelo; TELAROLLI, Sylvia (Orgs.). Literatura e política brasileira no século XX. São Paulo: Cultura Acadêmica, 2006, p.115-141.

FREIRE, Marcelino (Org.). Os cem menores contos brasileiros do século. Cotia, SP: Ateliê Editorial, 2004.

FRIEDMAN, Norman. Recent Short Story Theories. In: LOHAFER, Susan; CLAREY, Jo Ellyn (Ed.). Short Story at a Crossroads. Baton Rouge, LA and London: Louisiana State University Press, 1989, p.13-31.

Form and Meaning in Fiction. Athens: The University of Georgia Press, 1975.

GARDNER, John. What Writers Do. In: On Writers and Writing. Reading, MA: Perseus, 1994, p.216-227.

GEELHAAR, Christian. Jasper Johns Working Proofs. London: Petersburg Press, 1980.

GILMAN, Richard. Introduction. In: SHEPARD, Sam. Seven Plays. New York: Dial Press, 2005, p.xi-xxvii. 
GÖRMEZ, Aydin. Man, Woman, Violence and Sam Shepard. Tiyatro Araştırmaları Dergisi, Ankara, Türkiye, v. 24, p.125-143, 2007.

GREGSON, Ian. Postmodern Literature. London: Arnold/Oxford, 2004.

GROOPMAN, Jerome. That Buzzing Sound: The Mystery of Tinnitus. The New Yorker, New York, v. 85, n. 1, p.42-49, Feb. 2009.

HALL, Ann C. Sam Shepard's Nondramatic Works. In: ROUDANÉ, Matthew (Ed.). The Cambridge Companion to Sam Shepard. Cambridge: Cambridge University Press, 2002, p.247-256.

HALL, Stuart. The Question of Cultural Identity. In: HALL, Stuart; HELD, David; McGREW, Tony (Eds.). Modernity and its Futures. Cambridge: Polity, 1992, p.273-316. Minimal Selves. In: APPIGNANESI, Lisa (Ed.). The Real Me: Post-modernism and the Question of Identity. ICA Documents 6. London: The Institute of Contemporary Arts, 1987, p.44-46.

HALlETT, Cynthia Whitney. Minimalism and the Short Story: Raymond Carver, Amy Hempel, and Mary Robison. Lewiston, NY: Edwin Mellen, 1999.

HANSEN, Tom. Who's A Fool? A Rereading of Sherwood Anderson's 'I'm A Fool'. Midwest Quarterly. Pittsburgh, KS, v. 38, n. 4, p.372-379, sum. 1997.

HASSAN, Ihab. The Postmodern Turn: Essays in Postmodern Theory and Culture. Columbus: Ohio University Press, 1987.

HEMINGWAY, Ernest. Men Without Women. New York: Penguin, 1955.

HEMMINGSON, Michael. The Dirty Realism Duo: Charles Bukowski \& Raymond Carver. Los Angeles: Borgo Press, 2008.

HEMPEL, Amy. Reasons to Live. New York: Knopf, 1985.

HIGGINS, Dick. A Dialectic of Centuries: Notes Toward a Theory of the New Arts. New York: Printed Editions, 1978.

HILLS, Rust. Writing in General and Short Story in Particular. New York: Mariner, 2000 [1977]. 
HOHENDAHL, Peter Uwe. Introduction to Reception Aesthetics. New German Critique, v. 1, n. 10, p.29-63, Winter 1977.

HOLDEN, Stephen. Horse Racing and Other Rigged Games of Chance. The New York Times, New York, 4 Feb. 2000. Section E, p.17.

HONDERICH, Ted (Ed.). The Oxford Guide to Philosophy. Oxford, New York: Oxford University Press, 2005.

HUTCHEON, Linda. A Poetics of Postmodernism: History, Theory, Fiction. New York and London: Routledge, 1988.

HUYSSEN, Andreas. After the Great Divide: Modernism, Mass Culture, Postmodernism. Bloomington: Indiana University Press, 1986.

. The Search for Tradition: Avant-garde and Postmodernism in the 1970s. In: DOCHERTY, Thomas (Ed.). Postmodernism: A Reader. New York: Columbia University Press, 1993, p.220-236.

IFTEKHARRUDIN, Farhat et al. (Ed.). Postmodern Approaches to the Short Story. Westport, CT and London: Praeger, 2003.

ISER, Wolfgang. Do I Write for an Audience? PMLA: Publications of the Modern Language Association of America, v.115, n.3, p.310-314, May 2000.

JAMES, Caryn. Cast Adrift. Rev. Great Dream of Heaven by Sam Shepard. The New York Times Book Review. New York, 03 Nov 2002. Section 7, Column 3, p.30.

JAMESON, Fredric. Pós-modernismo: a lógica cultural do capitalismo tardio. 2.ed. Tradução de Maria Elisa Cevasco. São Paulo: Ática, 2006 [1991].

Postmodernism Or, The Cultural Logic of Late Capitalism. Durham NC: Duke University Press, 1991. . Third-World Literature in the Era of Multinational Capitalism. Social Text, v.1 n.15, p.65-88, 1986.

JARRELL, Donna. The Challenge of "June Recital": Generic Considerations in the Structure of The Golden Apples. In: IFTEKHARRUDIN, Farhat et al. (Ed.). Postmodern Approaches 
to the Short Story. Westport, CT and London: Praeger, 2003, p.3-8.

JOHNSON, Randal. Brazilian Narrative. In: KING, John (Ed). The Cambridge Guide to Modern Latin American Culture. Cambridge: Cambridge University Press, 2004, p.119134.

JOYCE, James. Dubliners. New York: Penguin, 1996.

JUST, Daniel. Is Less More? A Reinvention of Realism in Raymond Carver's Minimalist Short Story. Critique, v. 49, n. 3, p.303-317, spr. 2008.

JUSTICE, Charles. The Greatest Horse of All: A Controversy Examined. Bloomington, IN: AuthorHouse, 2008.

KAKUTANI, Michiko. On the New Frontier, Succumbing to Solitude. Rev. Great Dream of Heaven by Sam Shepard. New York Times Book Review. New York: Nov 05 2002. Late Edition, p.7.

KARMEL, Pepe. The Year of Living Minimally. Art in America, v.92, n.11, p.90-101,149, December 2004.

KING, Kimball. Introduction. In: (Ed.). Sam Shepard: A Casebook. New York and London: Garland, 1988, p.ix-xviii.

KLEIN, Melanie. Amor, culpa e reparação. In: ; RIVIERE, Joan. Amor, Ódio e Reparação: as emoções básicas do homem do ponto de vista psicanalítico. 2.ed. Tradução de Maria Helena Senise. Rio de Janeiro e São Paulo: Imago / Edusp, 1975, p.79162.

KLINGER, Diana Irene. Escritas de si, escritas do outro: o retorno do autor e a virada etnográfica. Rio de Janeiro: 7 Letras, 2007.

LAGE, Nilson. O texto das notícias impressas. In: Teoria e técnica do texto jornalístico. Rio de Janeiro: Elsevier/Ed.Campus, 2005, p.73-86.

LEROUX, Jean-François. Exhausting Ennui: Bellow, Dostoevsky, and the Literature of Boredom. College Literature, v. 35, n. 1, p.1-15, Winter 2008.

LIMA, Isabel Pires de. Traços pós-modernos na ficção portuguesa actual. Semear - Revista da 
Cátedra Padre António Vieira de Estudos Portugueses, n.4, PUC-RJ, p.1-9, 2000.

LISPECTOR, Clarice. Laços de família. 12.ed. Rio de Janeiro: José Olympio, 1982.

LOCKE, John. An Essay Concerning Human Understanding. Vol 1. New York: Dover Publications, 1959.

LOHAFER, Susan; CLAREY, Jo Ellyn (Ed.). Short Story at a Crossroads. Baton Rouge, LA and London: Louisiana State University Press, 1989.

LOPES JÚNIOR, Francisco Caetano. A questão pós-moderna vista da periferia: o caso João Gilberto Noll. Hispania, v. 73, n. 3, p.598-603, Sept 1991.

LYOTARD, Jean-François. Answering the Question: What Is Postmodernism? In: DOCHERTY, Thomas (Ed.). Postmodernism: A Reader. New York: Columbia University Press, 1993, p.38-46.

O pós-moderno. Tradução de Ricardo Corrêa Barbosa. 3.ed. Rio de Janeiro: José Olympio, 1988 [1979].

MAGALHÃES, Maria Flávia Armani Bueno. João Gilberto Noll: um escritor em trânsito. 1993. 345 f. Dissertação (Mestrado) - Instituto de Estudos da Linguagem, Universidade Estadual de Campinas, 1993.

MAJOR NETO, José Emílio. Contos novos: idílio em fragmentos. 2001. 183 f. Dissertação (Mestrado) - Instituto de Estudos da Linguagem, Universidade Estadual de Campinas, Campinas-SP, 2001.

MALIN, Irving. Sam Shepard: Great Dream of Heaven. Review of Contemporary Fiction, v. 23, n. 1, p.145, Spr 2003.

MARCHEZAN, Luiz Gonzaga. O hipotexto de Noll. Revista Brasileira de Literatura Comparada. n.9, Rio de Janeiro: 2006, p.229-242.

McDONOUGH, Carla J. Patriarchal Pathology from The Holy Ghostly to Silent Tongue. In: ROUDANÉ, Matthew (Ed.). The Cambridge Companion to Sam Shepard. Cambridge: Cambridge University Press, 2002, p.154-170.

McGHEE, Jim. True Lies: The Architecture of the Fantastic in the Plays of Sam Shepard. 
New York: Peter Lang, 1993.

McGUIGAN, Jim. Modernity and Postmodern Culture. Buckingham, PA: Open University Press, 1999.

McHALE, Brian. Postmodernist Fiction. London and New York: Routledge, 1987.

MESSUD, Claire. Death Be Not Allowed. Newsweek, v. 153, n.11, p.56-57, March 16, 2009.

MILlHAUSER, Steven. The Ambition of the Short Story. The New York Times. New York: 05 Oct 2008, p.BR31.

MOISÉS, Massaud. A criação literária: introdução à problemática da literatura. 7ed. São Paulo: Melhoramentos e Edusp, 1975.

Guia prático de análise literária. 3.ed. São Paulo: Cultrix, 1972.

MORELAND, Kim. Just the Tip of the Iceberg Theory: Hemingway and Sherwood Anderson's 'Loneliness'. The Hemingway Review. Moscow, ID, v. 19, n. 2, p.47-56, spr. 2000.

MORICONI, Italo. The Postmodern Debate: Brazilian Force Fields - An Introductory Overview (Working Paper). Journal of Latin American Cultural Studies, v. 14, n. 3, p.355-370, Dec 2005.

MOSS, Steve (Ed.). The World's Shortest Stories. Philadelphia, PA: Running Press, 1998.

MURPHY, Brenda. Shepard Writes About Writing. In: ROUDANÉ, Matthew. The Cambridge

Companion to Sam Shepard. Cambridge: Cambridge University Press, 2002, p.123-138.

NIETZSCHE, Friedrich. A gaia ciência. Tradução de Márcio Pugliesi et al. São Paulo: Hemus, 1976.

NOLL, João Gilberto. Acenos e afagos. Rio de Janeiro: Record, 2008.

A máquina de ser. Rio de Janeiro: Nova Fronteira, 2006.

. Hotel Atlântico. São Paulo: Francis, 2004.

Mínimos, múltiplos, comuns. São Paulo: Francis, 2003a.

O quieto animal da esquina. São Paulo: Francis, 2003b. 
Berkeley em Bellagio. São Paulo: Francis, 2003c.

Canoas e marolas. Série Plenos Pecados: Preguiça. Rio de Janeiro: Objetiva, 1999.

Romances e contos reunidos. São Paulo: Companhia das Letras, 1997a.

Interview with João Gilberto Noll. Journal of Latin American Cultural Studies, London, v. 6, n. 2, p.123-130, 1997b. Entrevista concedida a David Treece.

. A céu aberto. São Paulo: Companhia das Letras, 1996.

Harmada. São Paulo: Companhia das Letras, 1993.

Rastros do verão. Rio de Janeiro: Rocco, 1990.

A fúria do corpo. Rio de Janeiro: Rocco, 1989.

OLSEN, Ole Andkjær. Depression and Reparation as Themes in Melanie Klein's Analysis of the Painter Ruth Weber. The Scandinavian Psychoanalytic Review, n.27, p.34-42, 2004.

OTSUKA, Edu Teruki. Marcas da catástrofe: experiência urbana e indústria cultural em Rubem Fonseca, João Gilberto Noll e Chico Buarque. São Paulo: Nankin, 2001.

PENA, Felipe. Teoria do jornalismo. São Paulo: Contexto, 2005.

PERLOFF, Marjorie. The Poetics of Indeterminacy: Rimbaud To Cage. Illinois: Northwest University Press, 1993

PLANT, Sadie. the matrix - cyberfeminist simulations. In: SHIELDS, R. (Ed.). Cultures of Internet: Virtual Spaces, Real Histories, Living Bodies. London and Thousand Oaks, CA: Sage, 1996.

POE, Edgar Allan. Edgar Allan Poe's Complete Poetical Works. New York: Hard Press, 2006.

PROCTOR, Elizabeth. Offbeat Humor and Comic Mystery in Shepard's Plays: La Turista, The Unseen Hand, The Mad Dog Blues, and Forensic and the Navigators. In: KING, Kimball (Ed.). Sam Shepard: A Casebook. New York and London: Garland, 1988, p.31-51.

PROUlX, Annie. The Art of Fiction n. ${ }^{\circ}$ 199. The Paris Review, New York, v. 51, n. 188, p.22-49, Spr. 2009. Entrevista concedida a Christopher Cox. 
Brokeback Mountain. New York: Scribner, 2005.

RAFFA, Cláudia R. Sarraceni. Os fios e a teia: Mínimos, Múltiplos, Comuns de João Gilberto Noll. 2007. 225p. Dissertação (Mestrado) - Universidade Federal de Mato Grosso do Sul, Três Lagoas, 2007.

REAL, Jere. Shepard Writes of Conflicts. Rev. Great Dream of Heaven. Richmond Times Dispatch, Richmond, VA, 29 Dec. 2002, p.E4.

RINCÓN, Carlos. La no simultaneidad de lo simultáneo: Postmodernidad, globalización y culturas en América Latina. 2.ed. Bogotá: Universidad Nacional, 1995.

ROSENFELD, Anatol. Literatura e personagem. In: et al. A personagem de ficção.

9.ed. São Paulo: Perspectiva, 1998, p.10-49.

ROUDANÉ, Matthew. The Cambridge Companion to Sam Shepard. Cambridge: Cambridge University Press, 2002.

RUBENSTEIN, Roberta. Fragmented Bodies / Selves / Narratives: Margaret Drabble's Postmodern Turn. Contemporary Literature, Madison, v. 35, n. 1, p.136-146, spr 1994.

RULAND, Richard; BRADBURY, Malcolm. From Puritanism to Postmodernism: A History of American Literature. New York: Viking, 1991.

SANTIAGO, Silviano. Reading and Discursive Intensities: On the Situation of Postmodern Reception in Brazil. Boundary 2, v. 3, n. 20, p.194-202, 1993.

SANTOS, Boaventura de Souza. Pela mão de Alice: o social e o político na pósmodernidade. 7.ed. São Paulo: Cortez, 2000.

SANTOS, Josalba Fabiana dos. Diferentes olhares em João Gilberto Noll. Todas as Letras: Revista de língua e literatura, v.7, n.7, p.17-23, 2005.

SARAMAGO, José. Ensaio sobre a cegueira. São Paulo: Companhia das Letras, 1995.

SEIDEL, Roberto Henrique. João Gilberto Noll no contexto da mudança dos paradigmas romanescos dos anos 80. In: Do futuro do presente ao presente contínuo: modernismo vs. pós-modernismo. São Paulo: Annablume, 2001, p.127-134.

SHAKESPEARE, William. The Complete Works of William Shakespeare. London: Geddes 
\& Grosset, 2006.

SHAPARD, Robert; THOMAS, James (Ed.). New Further Sudden Stories: Short-Short

Stories From America and Beyond. New York: W. W. Norton, 2007.

. Sudden Stories. Layton, UT: Gibbs Smith, 1993.

SHEPARD, Sam. Day Out of Days. New York: Knopf, 2010.

. Kicking a Dead Horse. Foreword by Stephen Rea. New York: Vintage, 2008.

. Fool For Love and Other Plays. New York: Dial Press, 2006.

. Seven Plays. New York: Dial Press, 2005a.

. The God of Hell. New York: Dramatists Play Service, 2005b.

. Grande sonho do céu. Tradução de Sérgio Viotti. São Paulo: Arx, 2003.

Great Dream of Heaven. New York: Knopf, 2002a.

. The Late Henry Moss / Eyes For Consuela / When The World Was Green:

Three Plays. New York: Vintage, $2002 b$.

. Cruising Paradise. New York: Knopf, 1996a.

. Simpatico. New York: Vintage, 1996b.

. The Unseen Hand and Other Plays. New York: Vintage, 1996c.

. A Lie of the Mind. New York: Dramatists Play Service, 1986.

. Fool For Love \& The Sad Lament of Pecos Bill on the Eve of Killing His Wife.

San Francisco: City Lights, 1983.

Motel Chronicles. With Photographs by Johnny Dark. San Francisco: City Lights, 1982.

Hawk Moon. New York: PAJ, 1981 [1973].

SHEWEY, Don. Sam Shepard. Updated Edition. New York: Da Capo Press, 1997.

SIEGEL, Mark. Holy Ghosts: The Mythic Cowboy in the Plays of Sam Shepard. Rocky 
Mountain Review of Language and Literature, v. 36, n. 4, p.235-246, 1982.

SILVA, Antonio Manoel dos Santos. Análise do texto literário: orientações estilísticas. Curitiba: Criar Edições, 1981.

SILVA, Tomás Tadeu da. A produção social da identidade e da diferença. In: (Org.).

Identidade e diferença: A perspectiva dos Estudos Culturais. 4.ed. Petrópolis, RJ: Vozes, 2005 [2000], p.73-102.

SIMON, Luiz Carlos Santos. O conto e o pós-modernismo: recorte, velocidade e intensidade. Investigações, v.20, s.1, p.127-148, 2007.

SKRAINKA, Sarah Lynn. L'Enfant de sable: roman de l'ambiguïté. 1993. Dissertação (Mestrado) — University of Virginia, 1993.

SMITH, Lewis Worthington. The Writing of the Short Story. Boston: D.C. Heath, 1902.

SMITH, Philip. Cultural Theory: An Introduction. Oxford: Blackwell, 2001.

SOBREIRA, Ricardo da Silva. Figural Forms of Knowledge: A Study of the Short Prose of Sam Shepard. Signótica, v.20, Universidade Federal de Goiás, p.195 - 207, 2008.

No Earthly Clue: The Elliptical and Indeterminate Narratives of Sam Shepard and João Gilberto Noll. Revista da ANPOLL (Associação Nacional de Pós-Graduação e Pesquisa em Letras e Linguística), v.1, n.22, p.173-185, jan./jun., Brasília: UnB, 2007a.

O caráter provisório do sujeito na ficção de João Gilberto Noll. Revista Letras, v.1, Curitiba: Universidade Federal do Paraná, p.63-77, 2007b.

As estratégias de representação ficcional das contingências humanas em contos de Raymond Carver. 2005. 191p. Dissertação (Mestrado) - Universidade Estadual Paulista, São José do Rio Preto, 2005.

SOJA, Edward W. Taking Los Angeles Apart. In: Postmodern Geographies: The

Reassertion of Space in Critical Social Theory. London: Verso, 1989, p.222-248.

STAIGER, Emil. Estilo lírico: a recordação. In: Conceitos fundamentais da poética.

Tradução de Celeste Aída Galeão. Rio de Janeiro: Tempo Brasileiro, 1975, p.19-75.

STERNE, Jerome. (Ed.) Micro Fiction: An Anthology of Really Short Stories. New York 
and London: W.W. Norton \& Company, 1996.

STEVENSON, Diane. Minimalist Fiction and Critical Doctrine. Mississippi Review, v. 40-41, n. 1, p.83-89, winter 1985.

SUTHERLAND, John. Production and Reception of the Literary Book. In: COYLE, M. et al (Ed.). Encyclopedia of Literature and Criticism. London: Routledge, 1990, p.809-938.

TARQUINIO, J. Alex. Fear Stalks Shepard's West. Rev. Great Dream of Heaven. San Francisco Chronicle, San Francisco, 27 out. 2002. Entertainment, p.RV2.

THEISS, Nola. Shepard, Sam: Great Dream of Heaven, Stories. Kliatt, v. 38, n. 2, p.28, mar 2004.

TODOROV, Tzvetan. Introdução à literatura fantástica. São Paulo: Perspectiva, 1980.

TOLSTÓI, Leo. A morte de Ivan Ilitch. Porto Alegre: L\&PM, 2008.

TREECE, David. Prefácio. In: NOLL, João Gilberto. Romances e contos reunidos. São Paulo: Companhia das Letras, 1997, p.7-16.

TRODD, Colin. Postmodernism and Art. In: SIM, Stuart (Ed.). The Routledge Companion to Postmodernism. London and New York: Routledge, 2001, p.89-100.

UPDIKE, John. From Notes and Comment. The New Yorker, New York, v. 85, n. 1, p.68, Feb. 2009 [1962].

VAN DIJK, Teun A. Cognitive Processing of Literary Discourse. Poetics Today. v.1, p. 143$160,1979$.

VATTIMO, Gianni. O fim da modernidade: niilismo e hermenêutica na cultura pósmoderna. Tradução de Eduardo Brandão. 2.ed. São Paulo: Martins Fontes, 2007.

VILLAÇA, Nizia. Paradoxos do pós-moderno: sujeito \& ficção. Rio de Janeiro: UFRJ, 1996. VOGELIUS, Christa. Heaven Can Wait. Rev. Great Dream of Heaven by Sam Shepard. The Daily Targum, 13 Mar 2003. Disponível em:<http://www.dailytargum.com/news/2003 /03/ 13/InsideBeat/Heaven.Can.Wait-391879.shtml> Acesso em: 01 Nov 2004.

WEIS, José. João Gilberto Noll: o tempo da cigarra. Brasil/Brazil, Rio Grande do Sul, n.17, 
p.79-94, 1997.

WETZSTEON, Ross. Introduction. In: SHEPARD, Sam. Fool For Love and Other Plays.

New York: Dial Press, 2006, p.1-15.

WHEELER, A. M. Animal Imagery as Reflection of Gender Role in Clarice Lispector's Family Ties. Critique, v. 28, n. 3, p.125-134, spr. 1987.

WHITCOMB, Selden L. The Study of a Novel. Boston: D.C. Heath \& Co., 1905.

WINTERSON, Jeanette. Oranges Are Not the Only Fruit. London: Vintage, 1991.

WOODWARD, Kathryn. Identidade e diferença: uma introdução teórica e conceitual. In: SILVA, Tomaz Tadeu da Silva (Org. e Trad.) Identidade e diferença: A perspectiva dos Estudos Culturais. 4.ed. Petrópolis, RJ: Vozes, 2005 [2000], p.7-72.

YAMASHITA, Karen Tei. Tropic of Orange. Minneapolis, MN: Coffee House, 1997.

ZELLAR, Brad. Short Stories by Playwright Shepard Mostly Shine. Rev. Great Dream of Heaven by Sam Shepard. Minneapolis Star Tribune, Minneapolis, MN, 20 Oct 2002, p.20. ZOLTÁN, Abádi-Nagy. Minimalism vs. Postmodernism in Contemporary American Fiction. Neohelicon, v. 28, n. 1, p.129-144, Jan 2001.

\section{Referências a outras mídias}

BLACK HAWK DOWN (Falcão negro em perigo). Direção: Ridley Scott. Produção: Jerry Bruckheimer e Ridley Scott. Intérpretes: Josh Hartnett; Eric Bana; Sam Shepard; Ewan McGregor; Orlando Bloom et al. Roteiro: Ken Nolan e Steve Zaillian. EUA: Revolution Studios, c.2002. 1 DVD (144 min), color. Produzido por: Columbia Pictures. Baseado no romance homônimo de Mark Bowden.

DON'T COME KNOCKING (Estrela solitária). Direção: Wim Wenders. Produção: Peter Schwartzkopff e outros. Intérpretes: Sam Shepard; Jessica Lange; Tim Roth; Sarah Polley e outros. Roteiro: Sam Shepard e Wim Wenders. EUA / Alemanha / França: Europa Filmes, c.2005. 1 DVD (124 min), color. Produzido por: EuroArts Medien AG/ Sony Pictures. 
FOOL FOR LOVE (Louco de amor). Direção: Robert Altman. Produção: Menahen Golan e Yoram Globus. Intérpretes: Sam Shepard; Kim Basinger; Randy Quaid; Harry Dean Stanton e outros. Roteiro: Sam Shepard. EUA: The Cannon Group, c.1985. 1 DVD (106 min), color. Produzido por: MGM Home Entertainment. Baseado na peça Fool For Love de Sam Shepard.

HOTEL ATLÂNTICO. Direção: Suzana Amaral. Produção: Ari Pini. Intérpretes: Júlio Andrade, Mariana Ximenes, Gero Camilo e outros. Roteiro: Suzana Amaral. Brasil: Planifilmes, c2009 (110 min), color. Produzido por: Cinemalink. Baseado no romance Hotel Atlântico de João Gilberto Noll.

NUNCA FOMOS TÃO FELIZES. Direção: Murilo Salles. Produção: Mariza Leão. Intérpretes: Cláudio Marzo; Roberto Bataglin; Suzana Vieira e outros. Roteiro: Alcione Araújo e Jorge Durán. Brasil: Cinefilmes, c1983. 1 VHS (96 min), color. Produzido por: Cinefilmes. Baseado no conto "Alguma coisa urgentemente” de João Gilberto Noll.

PARIS, TEXAS. Direção: Wim Wenders. Produção: Anatole Dauman; Pascale Dauman e outros. Intérpretes: Harry Dean Stanton; Dean Stockwell; Natassja Kinski e outros. Roteiro: Sam Shepard e L.M. Kit Carson. Alemanha / França / Reino Unido / EUA: Road Movies Filmproduktion, c.1984. 1 DVD (147 min), color. Produzido por: 20th Century Fox.

RUFFIAN. Direção: Yves Simoneau. Produção: David Dwyer. Intérpretes: Sam Shepard; Frank Whalley; Laura Bailey; Nicholas Pryor et al. Roteiro: Jim Burnstein; Ross Parker; Garrett K. Schiff. EUA: ESPN Original Entertainment, c.2006. 1 DVD (89 min), color. Produzido por: ESPN Original Entertainment.

SILENT TONGUE. Direção: Sam Shepard. Produção: Caroline Pfeiffer; Ludi Boeken. Intérpretes: Richard Harris; River Phoenix; Alan Bates; Dermot Mulroney e outros. Roteiro: Sam Shepard. EUA / Reino Unido / França: Le Studio Canal+, c.1992. 1 DVD (102 min), color. Produzido por: Trimark Pictures.

SIMPATICO. Direção: Matthew Warchus. Produção: Sue Baden-Powel e outros. Intérpretes: Nick Nolte; Jeff Bridges; Sharon Stone; Albert Finney e outros. Roteiro: Matthew Warchus e David Nicholls. EUA: Canal+, c.1999. 1 DVD (106 min), color. Produzido por: Canal+. Baseado na peça Simpatico de Sam Shepard. 
THE ASSASSINATION OF JESSE JAMES BY THE COWARD ROBERT FORD. Direção: Andrew Dominik. Produção: Ridley Scott; Brad Pitt; Dede Gardner et al. Intérpretes: Brad Pitt; Casey Affleck; Sam Shepard; Mary-Louise Parker et al. Roteiro: Andrew Dominik. EUA: Warner Bros. Pictures, c.2007. 1 DVD (160 min), color. Produzido por: Warner Bros. Pictures. Baseado no romance homônimo de Ron Hansen.

THE RIGHT STUFF (Os eleitos). Direção: Philip Kaufman. Produção: Irvin Winkler; Robert Chartoff. Intérpretes: Scott Glenn; Ed Harris; Sam Shepard; Dennis Quaid e outros. Roteiro: Philip Kaufman. EUA: The Ladd Company, c.1983. 2 DVDs (193 min), color. Produzido por: Warner Home Video. Baseado no romance homônimo de Tom Wolfe.

THIS SO-CALLED DISASTER. Direção: Michael Almereyda. Produção: Jonathan Sehring; Caroline Kaplan e outros. Intérpretes: Sam Shepard; Sean Penn; Nick Nolte; Woody Harrelson e outros. Documentário. Estados Unidos: IFC Films, c.2004. 1 DVD (89 min), color. Produzido por: MGM. 
ANEXO I: 
Print

\section{Re: Publicação sobre NOLL}

From: João Gilberto Noll (jgnoll@via-rs.net)

Sent: Thursday, September 27, 2007 6:12:30 PM

To: Ricardo Sobreira (ricardosobreira@hotmail.com)

\section{Caro Ricardo Sobreira:}

Obrigado mesmo por ter enviado teu estudo. Só tenho condições, nesse momento, de fazer uma leitura rapidíssima, pois venho escrevendo um romance de forma veemente.

Mas já gostei. A questão da indeterminação é mesmo forte no meu trabalho. De uma certa forma, em mim, faz parte de um plano inconsciente, digamos. É minha sensação mestra na escrita.

Gostaria muito de ver teu estudo no meu site, sim.

O espaço é de um designer. Roberto Schmitt-Prym.

seu email: rprym@.com.br

Comunique-se com ele, simQuando estiver incluído, por favor, me avise.

Grande abraço, João Gilberto Noll 


\section{AUTORIZAÇÃO}

Autorizo a reprodução xerográfica do presente trabalho para fins de pesquisa.

São José do Rio Preto, 12 de abril de 2010.

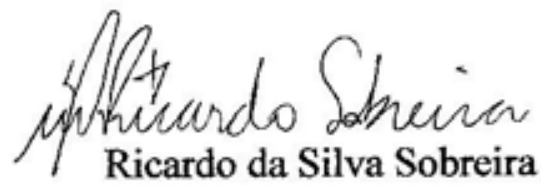

